\title{
Zorg op de grens : palliatieve zorg in ethisch perspectief
}

Citation for published version (APA):

van Osselen-Riem, J. (2003). Zorg op de grens : palliatieve zorg in ethisch perspectief. [Doctoral Thesis, Maastricht University]. Lemma. https://doi.org/10.26481/dis.20031217jo

Document status and date:

Published: 01/01/2003

DOI:

10.26481/dis.20031217jo

Document Version:

Publisher's PDF, also known as Version of record

\section{Please check the document version of this publication:}

- A submitted manuscript is the version of the article upon submission and before peer-review. There can be important differences between the submitted version and the official published version of record.

People interested in the research are advised to contact the author for the final version of the publication, or visit the DOI to the publisher's website.

- The final author version and the galley proof are versions of the publication after peer review.

- The final published version features the final layout of the paper including the volume, issue and page numbers.

Link to publication

\footnotetext{
General rights rights.

- You may freely distribute the URL identifying the publication in the public portal. please follow below link for the End User Agreement:

www.umlib.nl/taverne-license

Take down policy

If you believe that this document breaches copyright please contact us at:

repository@maastrichtuniversity.nl

providing details and we will investigate your claim.
}

Copyright and moral rights for the publications made accessible in the public portal are retained by the authors and/or other copyright owners and it is a condition of accessing publications that users recognise and abide by the legal requirements associated with these

- Users may download and print one copy of any publication from the public portal for the purpose of private study or research.

- You may not further distribute the material or use it for any profit-making activity or commercial gain

If the publication is distributed under the terms of Article $25 \mathrm{fa}$ of the Dutch Copyright Act, indicated by the "Taverne" license above, 
Zorg op de grens 
Beelden: Anneke Vigelius, Doorn

Gedichten: Jeanette van Osselen, Doorn

Foto's: Randal Scobie, Amsterdam

ISBN 90.5931-279-1

NUR 897

http://www.lemma.nl

infodesk@lemma.nl

(C) 2003 Uitgeverij LEMMA BV, Postbus 3320,3502 GH UTRECHT

Alle rechten voorbehouden. Niets uit deze uitgave mag worden verveelvoudigd, opgeslagen in een geautomatiseerd gegevensbestand of openbaar gemaakt in enige vorm of op enige wijze, hetzij elektronisch, mechanisch, door fotokopieēn, opnamen of enige andere manier, zonder voorafgaande schriftelijke toestemming van de uitgever.

Voor zover het maken van kopieèn uit deze uitgave is toegestaan op grond van artikel 16b Auteurswet $1912 \mathrm{j}^{\circ}$ het Besluit van 20 juni 1974, Stb. 351 zoals gewijzigd bij Besluit van 23 augustus 1985. Stb. 471 en artikel 17 Auteurswet 1912, dient men de daarvoor wettelijk verschuldigde vergoedingen te voldoen aan de Stichting Reprorecht, Postbus 3060, 2130 KB Hoofddorp. Voor het overnemen van éen of meer gedeelten uit deze uitgave in bloemlezingen, readers en andere compilatiewerken (artikel 16 Auteurswet 1912) dient men zich tot de uitgever te wenden.

Omslagontwerp en typografie: Twin Design BV, Culemborg 


\section{Zorg op de grens}

\section{palliatieve zorg in ethisch perspectief}

\section{Proefschrift}

ter verkrijging van de graad van doctor aan de Universiteit Maastricht, op gezag van de Rector Magnificus, Prof.dr. A.C. Nieuwenhuijzen Kruseman

volgens het besluit van het College van Decanen, in het openbaar te verdedigen op woensdag 17 december 2003 om 14.00 uur

door

Jeanette van Osselen - Riem 
Promotores:

Prof. dr. G.A.M. Widdershoven

Prof. dr. H.P. Kunneman (Universiteit voor Humanistiek, Utrecht)

Co-promotor: Dr. T.A. Abma.

De beoordelingscommissie:

Prof. dr. R. Vos (voorzitter):

Prof. dr. M. Huijer

Prof. dr. H. Manschot (Universiteit voor Humanistiek, Utrecht)

Prof. dr. C. Spreeuwenberg

Prof. dr. Z. Zylicz (Universiteit Bydgoszcz, Polen). 


\section{Inhoud}

Welkom aan de lezer

Inleiding 15

Doelstelling onderzoek

$\begin{array}{ll}\text { Opbouw van het boek } & 20\end{array}$

\section{Deel I Theorie}

I Palliatieve zorg in maatschappelijk en historisch perspectief 27

$\begin{array}{ll}\text { I.I Inleiding } 27 & 27\end{array}$

I.2 De 'onoplosbare' spanning tussen systeem en leefwereld 28

I.3 Mogelijkheden en problemen van de moderne tijd 33

I.3.I Het individu in de moderne samenleving 34

I.3.2 Life-politics 36

I.4 Maatschappijtheoretische begrippen van Habermas en
Giddens in relatie tot de palliatieve zorg

1.5 Palliatieve zorg-beweging 40

I.5.I Het systeem van de gezondheidszorg in Nederland 42

I.5.2 Palliatieve zorg, een leefwereld binnen het systeem van de $\begin{array}{ll}\text { gezondheidszorg } & 43\end{array}$

1.5.3 Opnieuw de spanning tussen systeemeisen en

I.6 Grondslagen van de palliatieve zorgverlening en ontstaans$\begin{array}{ll}\text { geschiedenis } & 45\end{array}$

I.6.1. De begrippen 48

I.7 Samenvatting $\quad 52$ 
2.I Inleiding 57

2.2 De regelethiek 58

2.2.1 De nieuwe gerichtheid van ethiek in de gezondheidszorg 58

2.2.2 Principes en stappenplan 60

2.2.3 De regelethiek in het spanningsveld tussen systeem en leefwereld, sterke en kwetsbare kanten van de regelethiek $\quad 65$

$\begin{array}{lll}2.3 & \text { De zorgethiek } 67\end{array}$

2.3.I Autonomie en kwetsbaarheid, positieve vrijheid 70

2.3.2 Dialoog als basis van de zorgethiek 72

2.3.3 Hermeneutiek 73

2.3.4 De zorgethiek in het spanningsveld tussen systeem en leefwereld,sterke en kwetsbare kanten van de zorgethiek $\quad 75$

2.4 Ethiek en palliatieve zorg op het snijvlak van systeem en leefwereld

$2.5 \quad$ Samenvatting

3 Ethiek in de praktijk: Communicatie in het spanningsveld tussen systeem en leefwereld $\quad 85$

$\begin{array}{lll}3.1 & \text { Inleiding } & 85\end{array}$

3.2 Communicatie in de praktijk 86

3.3 Communicatie als (hermeneutisch) leerproces 89

3.4 Communicatie op het snijvlak van systeem en leefwereld $\quad 9^{I}$

3.5 Communicatieve macht en onmacht van zorgverlener en organisatie 94

3.5.I De taal 96

3.6 Communicatie op verschillende niveaus 99

3.7 Microniveau: de relatie zorgverlener(s) - patiënten en naasten 100

3.7.1 Communicatie op microniveau IOI

3.7.2 De spanning tussen systeem en leefwereld 102

3.8 Mesoniveau: zorgverlenen binnen een zorginstelling $\quad 104$

3.8.I Communicatie op mesoniveau 105

3.8.2 De spanning tussen systeem en leefwereld 107

3.9 Macroniveau: de zorgorganisaties en de overheid Io8

3.9.I Communicatie op macroniveau 109

3.9.2 Spanning tussen systeem en leefwereld III

3.10 Samenvatting 112 


\section{Deel 2 Praktijk}

\begin{tabular}{|c|c|c|}
\hline 4 & Responsief onderzoek & 117 \\
\hline 4.I & Inleiding & II7 \\
\hline 4.2 & De responsieve onderzoeksbenadering: uitgangspunten & n18 \\
\hline 4.3 & Planning van activiteiten & 122 \\
\hline 4.4 & Introductiebijeenkomsten & 124 \\
\hline 4.5 & Participatie in de praktijk & 125 \\
\hline 4.6 & Fasen in het onderzoek & 127 \\
\hline 4.6.I & Praktijkverhalen & 127 \\
\hline 4.6 .2 & Interviews & 128 \\
\hline 4.6 .3 & Selectie van verhalen en opvattingen & 129 \\
\hline 4.6 .4 & Groepsgesprekken & 131 \\
\hline 4.7 & Validiteitsprocedures & 132 \\
\hline 4.8 & Samenvatting & 134 \\
\hline 5 & Ethiek als bron, of ethiek onder druk? & 139 \\
\hline 5.1 & Inleiding & 139 \\
\hline 5.2 & Definitie ethische problemen & 140 \\
\hline 5.2.1 & Vier praktijkverhalen en de reacties & 141 \\
\hline 5.2 .2 & $\begin{array}{l}\text { Regel-en zorgethische argumenten in een spanningsvolle } \\
\text { context }\end{array}$ & 149 \\
\hline $5 \cdot 3$ & Etische probleemsituaties & I5I \\
\hline 5.3.1 & Diepte-interviews & I5I \\
\hline 5.3 .2 & Omgaan met ethische problemen & 160 \\
\hline $5 \cdot 4$ & Samenspraak in groepsbijeenkomsten & 164 \\
\hline 5.4.I & De professionals & 164 \\
\hline $5 \cdot 4 \cdot 2$ & De vrijwilligers & 166 \\
\hline 5.5 & Samenvatting & 167 \\
\hline 6 & Integraal Zorg Overleg als vorm van moreel beraad & I7I \\
\hline 6.1 & Inleiding & 171 \\
\hline 6.2 & Integraal Zorg Overleg & 172 \\
\hline 6.3 & Plaats van ethiek in het overleg & 174 \\
\hline 6.4 & Ethische problemen & 176 \\
\hline 6.4.I & Verantwoordelijkheid voor kwaliteit van leven & 176 \\
\hline 6.4 .2 & Autonomie van de patiënt en aandacht voor de zorgbehoefte & 180 \\
\hline 6.5 & Hermeneutiek in praktijk & 183 \\
\hline 6.6 & De rol van de onderzoeker in het overleg & 185 \\
\hline
\end{tabular}


$\begin{array}{lll}6.7 & \text { Evaluatie IZO } & \text { I87 }\end{array}$

$\begin{array}{lll}6.8 & \text { Samenvatting } & 194\end{array}$

$7 \quad$ Ethisch kwaliteitsbeleid $\quad 199$

7.1 Inleiding 199

7.2 De dynamiek van 'trage vragen' rond sedatie 200

7.3 Discussie over het begrip sedatie 203

$\begin{array}{lll}7.4 & \text { Voorwaarden voor verantwoorde sedatie } & 207\end{array}$

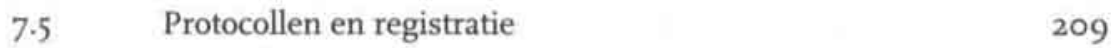

7.6 Verslaglegging sedatie voorvallen 210

7.6.1 Terugkerende vragen in het overleg 213

$\begin{array}{lll}7.6 .2 & \text { Registratie } 215\end{array}$

$\begin{array}{lll}7.7 & \text { Follow-up, beleid in de praktijk } & 216\end{array}$

$\begin{array}{lll}7.8 & \text { Moreel beraad } & 217\end{array}$

$\begin{array}{ll}7.9 & \text { Samenvatting } \\ & 220\end{array}$

Slotwoord en samenvatting $\quad 223$

$\begin{array}{ll}\text { Systeem-leefwereldspanning in palliatieve zorg } & 224\end{array}$

$\begin{array}{ll}\text { Ethiek } & 227\end{array}$

Communicatie 230

De responsieve methode $\quad 231$

Care on the Border, an ethical perspective on Palliative Care 233

$\begin{array}{ll}\text { Summary } & 233\end{array}$

$\begin{array}{lr}\text { Literatuur } & \mathbf{2 4 3}\end{array}$

$\begin{array}{lr}\text { Persoonsnamenregister } & \text { 251 }\end{array}$

$\begin{array}{lr}\text { Trefwoordenregister } & \mathbf{2 5 3}\end{array}$

$\begin{array}{lr}\text { Curriculum vitae } & \mathbf{2 5 5}\end{array}$ 
'Het dringt tot ons door dat er geen handreiking bestaat voor zingeving en geen zin voor lijden.

Wijzelf zullen een betekenis moeten geven aan deze pijn en aan dit verstoorde leven.'

Claire vanden Abbeele, 2001, p.16 



\section{Welkom aan de lezer}

Achteraf lijkt het een overmoedig waagstuk, een proefschrift over palliatieve zorg en ethiek te willen schrijven. Een waagstuk, waarvan ik de complexiteit en de impact op ons leven niet kon overzien toen ik eraan begon. Het begin van het project is niet scherp aan te geven. Het was een geleidelijk proces. De palliatieve zorg die zich vanaf begin jaren negentig in Nederland vestigde, trok mij aan en bracht mijn verpleegkundige achtergrond weer tot leven. In die pioniersfase liep ik met verschillende initiatieven mee, deed ik ervaring op en bood ondersteuning. Zo was ik betrokken bij de start van hospice Rozenheuvel, waar ik informatie en studiemiddagen organiseerde. Voor Stichting Elckerlijck verzorgde ik een aantal jaren het bulletin en voor Stichting De Schutshaven organiseerde ik informatiebijeenkomsten en onderwijs voor zorgverleners. De ervaringen die ik opdeed maakten mij bewust van de kwetsbaarheid van zorgverleners en patiënten in die zorg die zo omvattend wilde zijn.

Onze verhuizing naar Wenen in 1996 maakte geen einde aan die belangstel. ling. I $\mathrm{k}$ was benieuwd hoe in Oostenrijk de palliatieve zorg ervoor stond en al bij ons eerste verkennend bezoek aan Wenen dat tweeënhalf jaar onze woonplaats zou zijn, bezocht ik initiatiefgroepen en hospices. In een van die hospices heb ik tweeënhalf jaar lang drie ochtenden per week als vrijwilliger gewerkt. Die praktijkervaring was belangrijke input voor het schrijven van een curriculum over palliatieve zorg, waaraan ik inmiddels met een aantal mensen werkte en waarover ik contact hield met de Nederlandse achterban. Tegelijk confronteerde die praktijk me met situaties van diep menselijke ervaringen en vragen, die mijn gedachten op het spoor brachten van dit onderzoek. Het werd een stap voor stap proces. De eerste versies van een onderzoeksopzet, verkennende gesprekken met mogelijke begeleiders, het zoeken en bestuderen van literatuur, vonden in die periode plaats.

Toen we in oktober 1998 ons huis in Doorn weer betrokken, lag er een vastomlijnd plan. Een plan dat in de loop van de tijd, na vele gesprekken, toch regelmatig is bijgesteld. Er waren inmiddels tal van nieuwe hospice-voorzieningen in Nederland aan het ontstaan; als bestuurslid was ik betrokken bij de 
start van één daarvan, hospice Heuvelrug in een woonzorgcentrum in Zeist. In hospice Rozenheuvel mocht ik het veldwerk voor het onderzoek verrichten. Het was een leerzame en plezierige periode. Zorgverleners, professionals en vrijwilligers en ook het management van het hospice ben ik dankbaar voor hun vertrouwen en samenwerking. Speciale dank aan dr.Ben Zylicz en Ria van der Hel die ik ook na het praktijkonderzoek kon benaderen met vragen, veel profijt had $i k$ van hun inzichten en verhalen uit de praktijk.

Ook voor de gesprekken met mijn begeleiders over mijn ervaringen en teksten ben ik heel dankbaar. Guy Widdershoven, hoogleraar hermeneutiek aan de Universiteit Maastricht en Harry Kunneman, hoogleraar praktische humanistiek verbonden aan de Universiteit voor Humanistiek te Utrecht, hebben beiden veel invloed gehad op het uiteindelijke resultaat. Heel blij was ik ook met de steun en inspirerende begeleiding van Tineke Abma, verbonden aan de Universiteit van Maastricht. Met name in het laatste jaar heeft zij me begeleid bij het schrijven over het onderzoek in de praktijk. Zij stimuleerde me onconventionele vormen van presentatie te gebruiken. Gedichten en beelden, verhalen uit de praktijk bieden lezers een andere mogelijkheid om dicht bij het onderwerp van het onderzoek te staan en mee te (be)leven waarom het gaat.

Het boek is een uitnodiging tot reflectie en gesprek over de kwaliteit van zorg in het algemeen en voor mensen die door werk of op andere wijze bij palliatieve zorgpraktijken verbonden zijn.

Dank aan Esther en Anneco, mijn dochters die door het kritisch lezen van de tekst taal- en typefouten opspoorden en verbeterden en mij hielpen bij de vormgeving van het geheel. Net als Gijs-Bert, hun broer, steunden zij mij gedurende het hele proces door hun liefde, vertrouwen en bemoediging.

Het plotselinge overlijden in april 2002 van Bert, mijn man en maatje, betekent een onoverkomelijk verlies voor mij en de kinderen. Hij was mijn kracht en deelde mijn gedachten en dromen. Hij sterkte mij en ook anderen op hun weg, om bezig te zijn met dingen die ertoe doen, dat ook vol te houden. Hij schiep voor mij de voorwaarden om als vrijwilliger te werken, om te leren en me in te zetten voor wat we beiden belangrijk vonden. Onze lange wandeltochten, waarvoor we regelmatig tijd vrij maakten, waren gelukkige oasen waarin we kilometers stil naast elkaar liepen, woordeloos genoten, maar ook urenlang konden praten over alles wat ons bezighield. Mijn inspanningen waren ook zijn inspanningen, het resultaat ook van hem. 
Straks zitten wij weer samen in het gras, het licht, de kleuren, alles dieper, mooier dan het hier ooit was. Sprakeloos herkennen we, lachen we en jij houdt me vast.

De helpers die mij vergezelden zijn er bij ze waren met zo velen en ze droegen mij toen ik geen uitzicht had, geen moed.

Dan neuriën ze zachtjes:

het is goed.

Straks zitten we weer samen in het gras, ik weer naast jou zoals het altijd was.

Geen overkant, geen grens meer die ons scheidt, jou nooit meer kwijt.

Jeanette 



\section{Inleiding}

Als de stilte in zijn kamer hem te veel werd, drukte hij op de alarmknop naast zijn stoel. Zijn gehoor was, net als zijn gezichtsvermogen de laatste tijd erg achteruit gegaan. Het 'ja, wat is er', dat door de intercom klonk, verstond hij niet. Nogmaals bellen, nog eens...'we komen zo!'. Het geluid raakt zijn oor: ze hebben hem gehoord...

Daarop begon hij te vertellen: een glas water wilde hij hebben, koud graag. En met wie hij eigenlijk sprak, dat vroeg hij ook nog. De intercom bleef stil, er was al neergelegd. Als na een uur de verzorgster zijn kamer binnenloopt, weet hij het niet meer. Waarom hij dan gebeld had?

Hij schreef me dat hij nu een katheter had. Hij was een oude man, 'een mens van de dag'. Alleen zijn geest was nog helder, dat vond hij een grote zegen. Zijn levenseinde dat zo dichtbij leek te komen, was een onderwerp waar we vaak over spraken. Hij verlangde er naar. De ongemakken van zijn lichaam vielen hem zwaar. Lopen ging niet meer, hij was nu helemaal op de rolstoel aangewezen.

We wandelden in de tuin van het grote huis waar hij verbleef. Ook als het regende. Gewapend met een regenpak gingen we naar buiten. Daarna koffie en een sigaartje en tijd voor lange gesprekken.

Ik leerde hem een aantal jaren eerder door toeval kennen in het kloosterbejaardenoord waar hij sinds zijn zeventigste jaar verbleef. We sloten vriendschap en $i k$ bezocht hem regelmatig. Het werd een periode die mij confronteerde met aangrijpende ervaringen. Een periode die mij uiteindelijk naar het pad van de palliatieve zorg leidde en die mij de moed gaf aan dit onderzoeksproject te beginnen.

Op een zondag belde hij me op. De operatie die hij aan een van zijn ogen had moeten ondergaan, was hem danig tegengevallen. Hij klonk wanhopig, dit wilde hij niet nog eens meemaken. De communicatie met de verzorgsters in het huis verliep buitengewoon moeizaam. In feite was er sprake van 'oorlog'. Ze 
vonden hem lastig, hij was niet aardig tegen de meisjes. Ook al niet toen hij nog gezond en zonder lichamelijke klachten was. Hij was heerszuchtig, liet zich niets zeggen.

In een gesprek dat ik naar aanleiding van verscheidene incidenten had met het hoofd van de verzorging, leerde ik dat de relatie altijd al slecht was. Een proces van jaren waarin, naarmate hij afhankelijker werd van de verzorging door zijn katheter, zijn gehoor, het slechte zien, het lopen, deze relatie alleen maar slechter werd. Hij praatte tegen een muur als hij angstig was, of iets nodig had. Onverkwikkelijke situaties deden zich voor.

's Nachts was hij bang en belde regelmatig, raakte verward en viel uit bed. Dit werd opgelost door hoge hekken om het bed te plaatsen. Hij schreeuwde en vocht er tegen. De hekken die hem moesten beschermen maakten hem nog angstiger, nu zat hij opgesloten, kon nergens heen. Het hoofd van de verzorging vertelde: hij belde op een nacht wel vijftig keer! We hebben het geturfd en besloten tenslotte de bel maar uit te zetten...

Ook overdag was hij nu vaak in de war. Hij maakte zich zorgen en leed onder de slechte relatie met de verzorging maar was niet bij machte dat bij hen ter sprake te brengen en iets te veranderen aan die situatie. Hij kon geen genade vinden in hun ogen. Hij mocht ook niet meer in de eetzaal eten waar hij altijd zijn vaste plaats had gehad. Hij was te ziek en te hulpbehoevend om tussen zijn gezonde medebroeders aan tafel te zitten. Boven, op de ziekenafdeling, tussen mensen die net als hij in de war waren, of helemaal niet meer communiceer. den, werd hij voor zijn bord gezet. Hoe hij ook tegensputterde, hij had niets meer in te brengen. Eten 'om het vol te kunnen houden' en ook zijn medicijnen die hij regelmatig weigerde, werden verstopt in zijn appelmoes of vla of hoe dan ook toegediend.

De oorlog woedde voort, de situatie was naar mijn gevoel eigenlijk onverdraaglijk. Dagelijks zocht ik hem op om hem een paar uurtjes gezelschap te houden en zo wat soelaas te bieden. Het wandelen en de gesprekken gingen door.

Steeds weer werd door de leiding van de verzorging aangevoerd dat het 'zijn eigen schuld' was.

De laatste weken sprak hij niet veel meer, zat stil in zijn stoel voor het raam en vond het fijn als ik naast hem kwam zitten. Het incident met de intercom, zoals hierboven beschreven, herhaalde zich regelmatig.

Zijn dood, een dag na zijn 83ste verjaardag, kwam als een bevrijding voor hem en voor zijn omgeving. In verschillende gesprekken na zijn overlijden, met ver- 
antwoordelijken, het management van het huis, bleef men vasthouden aan het standpunt, dat deze lastige patiënt de eenzaamheid en de moeilijkheden over zichzelf had afgeroepen. Verder deed men er het zwijgen toe

\author{
De grijze medebroeders \\ mijden het lijden \\ in hun midden, \\ zachtjes schuifelen zij \\ er aan voorbij, \\ de ogen neergeslagen \\ als in bidden \\ om het angstig voorgevoel \\ van wanneer treft het mij.
}

De periode van deze ervaringen, 1989-1994, was de tijd van de opkomst van de palliatieve zorgverlening in Nederland. Vanuit verschillende inspiraties ontstonden, veelal particuliere, initiatieven als het starten van hospices en 'bijna thuis-huizen' voor mensen die ongeneeslijk ziek zijn. Een ontwikkeling die vooral in Engeland, Canada en in de Verenigde Staten haar oorsprong had. Vrouwen als Dame Cicely Saunders, in Engeland en Elisabeth Kübler Ross, in Canada en de Verenigde Staten, waren de grondlegsters van deze manier van zorgverlenen.

Het beleid van de Nederlandse overheid was er in die periode (en ook nu nog) op gericht het accent van de zorg te verplaatsen naar de thuissituatie. Ongeneeslijk zieke patiënten zouden zo lang mogelijk thuis moeten blijven. Een beleid dat tegemoet komt aan de wens van steeds meer patiënten om thuis te sterven. Een voornemen ook dat inspeelt op toekomstverwachtingen. Het RIVM meldde in 1993 dat het totaal aantal personen met ziekten en aandoeningen, speciaal de langdurige ziekten die vooral op oudere leeftijd voorkomen, over 15 jaar met 25 tot $40 \%$ zal zijn gestegen (RIVM, I993. p. I7). Een stijging, die verband houdt met de groei en de vergrijzing van de bevolking.

Mijn kennismaking met de palliatieve zorgverlening vond plaats in die beginperiode. De filosofie van deze zorgverlening en de manier waarop men deze in praktijk probeerde te brengen, spraken me aan. $\mathrm{Zij}$ gaven ruimte voor, en antwoord op veel vragen uit bovenbeschreven periode en daarmee verbonden ervaringen.

De aandacht voor de zorg voor stervende mensen kwam voort uit een behoefte die men zag en vragen waarmee zowel zorgverleners als patiënten en familie in de praktijk van de zorg werden geconfronteerd. De conclusie 'we kunnen 
niets meer voor $u$ doen' werd omgebogen in 'we kunnen u niet meer beter maken, maar wel het lijden verlichten en bijdragen aan de kwaliteit van het leven dat nog rest.' Niet de ziekte of het niet meer beter kunnen worden, staan centraal, maar de mens en de betekenis die dit alles voor hem of haar heeft. Het gaat om degene die zorg nodig heeft en de mensen die direct daarbij betrokken zijn, familie, vrienden. Niet alleen het lichaam, de pijn heeft de aandacht van zorgverleners, maar de hele mens. Om deze filosofische uitgangspunten in praktijk te kunnen brengen was naast professionele kennis en vaardigheden van een multidisciplinair team van zorgverleners de hulp en betrokkenheid van vele vrijwilligers nodig.

De periode van ziekte en sterven van mijn oude vriend, was misschien een noodzakelijke confrontatie voor mij om de weg van de palliatieve zorgverlening in te slaan. Een slingerend pad vol idealen, dat wegleidt van situaties waarin mensen worden alleengelaten, waar geen ruimte is voor de existentiële pijn waarvoor mensen geen woorden kunnen vinden, waar rancune is in plaats van liefdevolle zorg. Een pad dat ook steeds met die situatie verbonden blijft als begin en bron van een zoektocht.

Ook mijn achtergrond als verpleegkundige en mijn latere studie pedagogiek voedden de aantrekkingskracht die de palliatieve zorgverlening op mij had. In 1997 had ik enkele jaren gewerkt voor de Stichting Elckerlyck te Austerlitz en studiemiddagen georganiseerd voor zorgverleners die daar belangstelling voor hadden, ook in hospice Rozenheuvel te Rozendaal. Voor de Stichting te Schutshaven te Rotterdam zette ik voorlichtings- en onderwijsactiviteiten op. Daarnaast nam ik het initiatief om een Leergang Palliatieve Zorg te ontwikkelen. In samenwerking met een aantal partners, verenigd in de Stuurgroep Palliatieve Zorg, werd deze Leergang in 1997 voltooid. In 1996 vertrok ik voor tweeënhalf jaar naar Oostenrijk, waar ik als vrijwilliger drie ochtenden per week werkzaam was in het St. Raphaëls Hospiz te Wenen.

$\mathrm{Na}$ het gereedkomen van de Leergang palliatieve zorgverlening in 1997 en mijn ervaringen in palliatieve zorgpraktijken, leek de tijd rijp voor nader onderzoek.

Een aantal vragen drong zich op. Hoe ideaal is de palliatieve zorgverlening in de praktijk? Hoe worden de filosofische en praktische uitgangspunten van deze zorg in de praktijk vormgegeven en levend gehouden? En, in het licht van deze uitgangspunten, hoe kan worden voorkomen dat situaties ontstaan waarin management en zorgverleners niet meer reflecteren op het eigen handelen, de eigen emoties en die van de mensen die op de zorg zijn aangewezen niet meer begrijpen en de morele dimensie van het omgaan met kwetsbare en afhankelijke mensen wegredeneren en veronachtzamen?

Als palliatieve zorgverlening wordt gezien als integraal deel van de gezond- 
heidszorg (Borst, 1999) en de palliatieve zorg een herkenbare en gerechtvaardige plaats heeft gekregen binnen het aanbod van zorgvoorzieningen, zijn dan daarmee de problemen opgelost? Zijn situaties als waarmee deze inleiding begint nu uitgesloten? Al deze vragen hebben geleid tot de opzet van dit onderzoek.

\section{Doelstelling onderzoek}

In de palliatieve zorgverlening staan communicatieve aspecten van zorg op de voorgrond, meer dan in andere zorgsituaties gebruikelijk of merkbaar is. Tegelijk is juist communicatie een van de probleemgebieden in de hedendaagse zorgverlening. Vanuit de maatschappijtheorie van Habermas (1982) en Giddens (200I) is dit probleem te begrijpen als botsing tussen systeem en leefwereld. Persoonlijke en professionele opvattingen en ervaringen worden geconfronteerd met systeemeisen van effectiviteit en rationele kennis. In de communicatie met andere disciplines, de communicatie tussen zorgverleners onderling, tussen zorgverleners en patiënt en met andere direct betrokkenen, zoals de familie van de patiënt, gaat het vaak juist om existentiële vragen en emotionele ervaringen. Problemen in communicatie kunnen leiden tot verlies van kwaliteit zowel ten aanzien van de zorgverlening aan patiënten en familie als ten aanzien van de kwaliteit van arbeidssatisfactie, of het welzijn van de zorgverleners (Kunneman, 1996 p. $24 \mathrm{I}$ ev.). Doel van het onderzoek is het beschrijven en verhelderen van de inherente spanning in de hedendaagse praktijk van de palliatieve zorgverlening en het zoeken naar handreikingen voor mensen die hiermee te maken hebben. Gezocht zal worden naar vormen van communicatief overleg en ethische reflectie die een bijdrage leveren aan de kwaliteit van de palliatieve zorg en aan het veiligstellen en verder ontwikkelen van de eigenheid van deze zorg.

In het eerste deel van het boek zal de palliatieve zorg worden geanalyseerd vanuit verschillende theoretische perspectieven: de maatschappijtheorie, de ethiek en de grondslagentheorie. Deze theorieën zullen worden gebruikt om de spanning rondom palliatieve zorg te verhelderen. Vanuit maatschappijtheoretisch gezichtspunt zullen hedendaagse ontwikkelingen in de zorg geduid worden in termen van systeem en leefwereld. Vanuit ethisch perspectief wordt de inzet van de palliatieve zorg als morele onderneming verduidelijkt. Daarbij wordt palliatieve zorg gesitueerd in het spanningsveld van regelethiek en zorgethiek. Vanuit de grondslagentheorie wordt ingegaan op communicatie als voorwaardenscheppende kwaliteit om ethische- en emotionele problemen en existentië- 
le vragen rond leven en sterven ter sprake te brengen en te herkennen. Tevens zal worden aangegeven wat de belemmeringen van communicatie zijn waardoor de kwaliteit van de zorgverlening onder druk kan komen te staan.

$\mathrm{Na}$ de theoretische verheldering van de spanningen rondom palliatieve zorg wordt in het tweede deel van het boek een verslag gedaan van een onderzoek naar de praktijk. Onderzocht wordt hoe de spanningen zich in de praktijk voordoen en welke concrete oplossingen op basis van de eerdergenoemde theorieën ontwikkeld kunnen worden. Tevens zal worden ingegaan op de moeilijkheden die gepaard gaan met het in praktijk brengen van de theoretische oplossingsmodellen.

\section{Opbouw van het boek}

Om recht te doen aan de complexe werkelijkheid van de zorgverlening en deze te kunnen beschrijven en analyseren heb ik me verdiept in theoretische achtergronden. Zo konden naast de ervaringen in de palliatieve zorg en de empirische data van het onderzoek, ook de maatschappelijke context van de tijd en de systemen waarvan de zorg deel uitmaakt een kader creëren van waaruit de palliatieve zorg en met name de morele dimensie van de zorg tot uitdrukking komt en begrepen kan worden. $\mathrm{Zij}$ vormen een noodzakelijke achtergrond om de opgedane ervaringen en de problemen die in het onderzoek aan de orde kwamen, te herkennen, te verhelderen en te zoeken naar aanknopingspunten om ermee om te gaan. Tegelijk leidt de wisselwerking tussen deze theoretische achtergronden en de praktijkervaringen tot mogelijke aanvulling of verdieping van de theorie. De theoretische perspectieven waarmee het boek begint, zijn die van de maatschappijtheorie, toegespitst op de (post)-moderne tijd, de ethiek en dan met name de in de gezondheidszorg gangbare regelethiek en de in opkomst zijnde zorgethiek en die van de voorwaardenscheppende rol van communicatie. De keuze van deze theoretische invalshoeken hangt samen met het doel van het onderzoek. Ontstaan en theorie van de palliatieve zorg kreeg in de voorbereiding van het onderzoek uiteraard ook alle aandacht. Vanuit de verschillende perspectieven van maatschappijtheorie en van ethiek en de daarmee verbonden rol van communicatie zal in het boek uiteen worden gezet wat palliatieve zorg is en wat de achtergronden zijn die tot haar ontstaan en ontwikkeling hebben geleid.

Het eerste deel (hoofdstukken I tot en met 3) beschrijft theoretische achtergronden. Hoofdstuk I beschrijft de (post)-moderne tijd. De in snel tempo opeenvolgende ontwikkelingen op gebied van wetenschap en techniek, pro- 
ductie en communicatie brengen nieuwe mogelijkheden met zich mee. In de gezondheidszorg zichtbaar doordat steeds meer ziekten succesvol kunnen worden bestreden en mensen langer in leven blijven. Een periode van veel veranderingen, specialistische kennis, democratisering van maatschappelijke verhoudingen, van secularisering en van keuzen in de zorg. In dit klimaat komt begin jaren negentig de palliatieve zorg in Nederland tot ontwikkeling. Habermas (I98I) is het vertrekpunt voor een schets van de maatschappijtheoretische achtergrond. Hij beschrijft hoe het moderniseringsproces van de nieuwe tijd heeft geleid tot rationalisering van domeinen die voorheen werden geleid door traditie, ideologie en hiërarchische verhoudingen, welke weinig vatbaar waren voor kritische reflectie. Rationalisering van de samenleving is verbonden met communicatieve processen, het beargumenteren, het uiteenzetten van goede redenen voor de juistheid van kennis en handelen. Niet alleen op het terrein van rationele kennis is dat zo, volgens Habermas is het ook mogelijk gezamenlijk, op grond van goede redenen, tot overeenstemming te komen over zingeving, over normen en waarden. Traditionele kaders worden kritiseerbaar en verliezen hun algemene geldigheid. Secularisering van de Westerse samenleving is een voorbeeld daarvan.

Habermas beschrijft een ideale communicatiegemeenschap, een rechtvaardige samenleving, waarin mensen op basis van gelijkheid en rationele argumenten samenleven en zin geven aan hun bestaan. Als probleem van de moderne tijd beschrijft hij de ongelijktijdigheid van de rationaliseringsprocessen zoals die zich afspelen in de domeinen van economie en materiële reproductie en die van de domeinen waar zich het privé-leven van mensen afspeelt. De nadruk op het belang van rationele kennis, economische groei en het beheersen van natuurlijke processen leidde tot verzelfstandiging van deze domeinen in systemen, waarbinnen weinig ruimte was voor kritische reflectie vanuit de leefwereld. Systemen en leefwereld verzelfstandigden zich van elkaar. Werk en privé werden meer en meer gescheiden terreinen; geld en macht factoren die een ideale communicatie bemoeilijken. Vragen over zingeving, over wat het leven goed maakt, wat werkelijk belangrijk is, blijven binnen het domein van de leefwereld, waar individuen op zichzelf zijn aangewezen. Waar Habermas de spanning tussen systeem en leefwereld en de daarmee gepaard gaande ongelijke communicatieve verhoudingen centraal stelt, gaat Giddens (200I) verder en brengt de werking van life-politics ter sprake, dat een interferentie mogelijk maakt tussen systeem en leefwereld. Hoewel existentiële en emotionele vragen en problemen, door rationalisering en het uiteengroeien van systeem en leefwereld, uit het leven lijken te worden weggedrukt, laat hij zien hoe deze aspecten toch weer door individuen of groeperingen naar voren worden gebracht en plaats vragen binnen zowel leefwereld als systemen. De palliatieve zorg wordt 
in dit hoofdstuk beschreven als voorbeeld van de werking van Giddens' life-politics.

Het opnieuw ter sprake brengen en present stellen van de ethische dimensies van de zorg voor stervenden kan worden geduid als een eerste beweging in het 'life political'-proces. Het ontwikkelen van een eigen ethiek zou een volgende stap betekenen om de herontdekte waarden in de palliatieve zorg te ondersteunen en zichtbaar te houden. Hoewel palliatieve zorg is ontstaan uit onvrede met het systeem, is het niet zo dat zij buiten het systeem kan functioneren. Institutionalisering van de palliatieve zorg zal gepaard gaan met spanning door systeemeisen, waardoor de eigenheid van palliatieve zorg onder druk kan komen te staan.

In hoofdstuk 2 komt het tweede theoretisch perspectief, ethiek, aan de orde. De spanning tussen de systeem en de leefwereld zoals die in het eerste hoofdstuk werd geschetst, vindt in dit hoofdstuk een toespitsing in het onderscheid tussen de regelethiek, verwant met de rationaliteit van het systeemdenken, en de zorgethiek, een benadering die meer verbonden is met de praktijk en de existentiële en emotionele dimensies van het bestaan van mensen.

Zorgethiek heeft meer leefwereldkenmerken. Regelethiek en zorgethiek maken op verschillende wijze duidelijk wanneer er sprake is van een ethisch probleem. Bij het uiteenzetten van beide ethische stromingen gaat het om de vraag of er een ethiek is die de spanning tussen systeem en leefwereld goed uitwerkt. Sterke en kwetsbare kanten van beide stromingen komen voor het voetlicht. De systematiek van de regelethiek geeft hulpverleners houvast in moeilijke situaties. Aan de hand van een stappenplan kan worden vastgesteld wat in bepaalde situaties goed en juist is. De regelethiek heeft met haar nadruk op autonomie bijgedragen aan emancipatie en gelijkwaardige verhoudingen. Met haar principe-benadering van regels, rechten en plichten draagt zij echter ook bij aan onpersoonlijke verhoudingen. Emoties en existentiële vragen maken geen deel uit van het stappenplan en de ethische discussie. De zorgethiek is meer betrokken op de praktijk en de persoonlijke beleving van waarden die in het geding zijn. Het dialogisch perspectief van de zorgethiek wordt uitgewerkt aan de hand van de hermeneutiek. De zorgethiek biedt mogelijkheden voor een 'veelstemmig' ethisch overleg. Door de sterke gerichtheid op relationele betrokkenheid en leefwereldervaringen draagt zij echter het gevaar in zich van isolement en blijven leefwereld en systeem van elkaar verwijderd. De praktijk van de zorg bevindt zich op het snijvlak van leefwereld en systeemeisen. De zorgethiek noch de regelethiek lijken voldoende bij te dragen om te spanning tussen leefwereldervaringen en systeemeisen goed uit te werken en de palliatieve zorg daarmee een fundament te verschaffen om haar eigenheid te bewaren. De spanning tussen leefwereldervaringen en behoeften en systeemeisen 
zetten het herkennen van en het spreken over morele- en existentiële ervaringen onder druk. Er moet daarom gezocht worden naar voorwaarden en mogelijkheden om ethiek in de praktijk vorm te geven op een wijze die ruimte biedt aan ervaringen, behoeften en achtergronden van mensen in moeilijke situaties en oog heeft voor de regels en normen van de systeemcontext waarbinnen deze plaatsvinden. Om te begrijpen waarom het gaat, wat die ervaringen en behoeften zijn en wat de betekenis en reikwijdte is van de systeemeisen, is communicatie vereist.

In hoofdstuk 3 gaat het om communicatie als voorwaardenscheppende kwaliteit van ethiek. Tegelijk zijn er ook beperkingen. De spanning tussen systeem en leefwereld maakt het soms moeilijk om ethische vragen en problemen te herkennen of ermee om te gaan. Daarnaast heeft talige communicatie ook beperkingen. Ingegaan wordt op de mogelijkheden en ook op de beperkingen van communicatie en het hermeneutisch perspectief. Niet alles is in argumenten uiteen te zetten (Kunneman, 1998) en van gelijke verhoudingen, belangrijke voorwaarde om ruimte te geven aan een dialoog, is in een patiënt arts/hulpverlener relatie, niet altijd sprake (Habermas, 198r; Tronto, 1993).

De omgeving speelt een belangrijke voorwaardenscheppende rol. Het is de verantwoordelijkheid van organisaties hiervoor oog te hebben en structureel communicatief overleg mogelijk te maken en de kwaliteit van het communicatieve klimaat hoog te houden. Dit is niet alleen van belang op het niveau van de werkplek waar de leefwereldervaringen van zorgverleners en patiënten een belangrijke rol spelen, maar ook op het niveau van het management en in de relatie met de overheid, waar juist de systeemwerking explicieter op de voorgrond staat. In dit hoofdstuk wordt ingegaan op de betekenis en de functie van communicatie en reflectie voor ethiek op die verschillende niveaus waarbinnen de zorg is georganiseerd.

Het tweede deel van het boek gaat over het praktijkonderzoek.

Hoofdstuk 4 is een uiteenzetting van de opzet en de methode van onderzoek. Het veldonderzoek werd verricht in hospice Rozenheuvel te Rozendaal en liep van september 1999 tot september 2000. Gekozen is voor een responsieve onderzoeksmethode (Guba \& Lincoln, 1989; Abma, 1996). Doel van deze benadering is om in dialoog met belanghebbenden in de onderzoekspraktijk een gesprek op gang te brengen over voor hen belangrijke issues en ervaringen met het oog op de kwaliteit van die praktijk. Na beschrijving van de methode en het werkveld, wordt uiteengezet welke activiteiten werden georganiseerd om die praktijk te leren kennen. Er vonden introductiebijeenkomsten plaats en aan de hand van praktijkverhalen werd een gesprek met de praktijk op gang gebracht. Naast het participerend aanwezig zijn, werden interviews gehouden 
met mensen die op verschillende manieren bij de zorg betrokken zijn. Het wekelijkse zorgoverleg werd bijgewoond om te kijken naar besluitvorming over ethische vragen die door zorgverleners werden ingebracht. Ook werden er multidisciplinaire groepsbijeenkomsten georganiseerd om verder te praten over relevante onderwerpen.

In hoofdstuk 5 en 6 worden de uitkomsten van het veldwerk beschreven. Hoofdstuk 5 gaat over ethische opvattingen in de praktijk. Om zicht te krijgen op ethische probleemsituaties wordt, aan de hand van een aantal verhalen uit de praktijk en door middel van interviews, met zorgverleners het gesprek aangegaan. De interpretaties van de schriftelijke reacties op de aan de zorgverleners uitgereikte praktijkvoorbeelden en van de interviews worden in verband gebracht met theoretische perspectieven. Thema's van zowel regelethiek als zorgethiek spelen een rol in het omgaan met ethische vragen en problemen. Hoofdstuk 6 gaat over het wekelijks Integraal Zorg Overleg (IZO) als vorm van moreel beraad. Naast communicatieve onmacht die wordt gesignaleerd is er bij zorgverleners ook sprake van de bereidheid de grenzen die men tegenkomt te accepteren. Wel leiden deze vaak weer tot nieuwe vragen, zoals de situatie van 'het verkeerde bed' laat zien. In het IZO bleek de benadering van ethische dimensie van het werk weinig systematisch en afhankelijk van personen die op dat moment in het overleg aanwezig zijn. In de discussies zijn regelethische en zorgethische argumenten herkenbaar. Daarbij valt het op dat het vooral verpleegkundigen zijn die de stem van de patiënt vertolken (die dat zelf vaak niet meer kan), relationele betrokkenheid tonen en opkomen voor kwaliteit van leven. In het omgaan met ethische problemen speelt de spanning tussen systeemeisen en leefwerelddimensies steeds weer een rol, waarbij regelethiek, het afwegen van waarden, leidinggevend is.

Ook aan het effect van de aanwezigheid van de onderzoeker in de praktijk wordt aandacht gegeven. Regelmatig wordt zij er door management en zorgverleners op attent gemaakt dat alleen al haar aanwezigheid ethiek meer centraal stelt. Hoe dit doorwerkt zonder die aanwezigheid is vooralsnog onzeker. Hoofdstuk 7 beschrijft een proces van beleidsontwikkeling. Aan de hand van een door zorgverleners ingebracht probleem wordt in een aantal opeenvolgende bijeenkomsten beleid ontwikkeld over hoe om te gaan met situaties waarin de pijn en symptomen niet meer afdoende behandeld kunnen worden en sedatie van de patiënt als optie wordt aangedragen om het lijden te verminderen.

Om de 'leesbaarheid', de begrijpelijkheid en de aantrekkelijkheid van het boek te vergroten, zijn beelden en gedichten door de tekst geweven. Maar niet alleen om deze redenen. Talige communicatie is beperkt. Door beelden en gedichten worden diepere lagen in onszelf aangesproken, andere zintuigen geprikkeld, 
waardoor de tekst voor een breder en meer divers publiek toegankelijk wordt. Het zijn vormen die uitnodigen om even stil te staan en die oproepen tot reflectie. Het merendeel van de gedichten is eerder verschenen in een bundel die in samenwerking met mijn vriendin en beeldend kunstenaar werd samengesteld, (Van Osselen en Vigelius, 1999). Zowel de beelden als de gedichten vinden hun bron in menselijke ervaringen en passen daarom in een boek over een zorgpraktijk, waarin die ervaringen centraal staan. 



\section{Palliatieve zorg in maatschappelijk en historisch perspectief}

\subsection{Inleiding}

Snelle ontwikkelingen en verandering kenmerken de huidige, (post)-moderne tijd. De nadruk ligt op meetbare kennis, op specialisatie, beheersbare processen en geloof in de vooruitgang. Traditionele waarden en overtuigingen worden bekritiseerd, maar niet vervangen door nieuwe zekerheden. Het concept van twijfel raakt geïnstitutionaliseerd, men gaat ervan uit dat kennis steeds voorlopig is (Giddens, 200I, p.3). Specialisatie en rationalisering van ervaringen hebben geleid tot het ontstaan van een kloof tussen domeinen waarin zich het privé-leven afspeelt en die waarin mensen deel uit maken van instituties. Daardoor lijken er steeds minder aanknopingspunten te zijn om gemeenschappelijk over levenservaringen te spreken en na te denken over zin en betekenis ervan.

In dit hoofdstuk wordt het maatschappelijk kader geschetst waarin de palliatieve zorgverlening in Nederland tot ontwikkeling kwam. Ik steun daarbij met name op de inzichten van Habermas en Giddens, maar ook ervaringen en inzichten van andere auteurs op dit terrein zullen in dit hoofdstuk aan de orde komen.

De ontwikkelingen van de moderne tijd en de invloed daarvan op mens en maatschappij werden gevolgd door de wetenschapsfilosofie en wetenschapsonderzoek om de ontwikkelingen rationeel te funderen of te kritiseren. De Duitse filosoof en socioloog Habermas (I98r) ontwikkelde een communicatietheoretisch perspectief waarmee hij de problemen van moderne maatschappijen blootlegt en richting geeft aan het oplossen ervan. Hij beschrijft de gegroeide tegenstelling tussen cognitief-instrumentele en communicatieve rationaliteit en wijst op het structurele communicatieve geweld, de kolonisering die plaatsvindt vanuit de systemen op de leefwereld van mensen. Door het verzelfstandigen van subsystemen als economie en staat, die voor hun functioneren en voortbestaan niet langer afhankelijk zijn van gedeelde communicatieve processen op leefwereldniveau, ontstaat een spanning tussen de systeem en leefwe- 
reld. Een spanning waar mensen in hun dagelijks bestaan mee worden geconfronteerd omdat zij van beide werelden deel uitmaken, in beide werelden moeten functioneren.

Ook het maatschappijtheoretisch perspectief van Giddens (2001), gaat in op de toegenomen rationaliteit en belicht hetzelfde thema, dezelfde spanning tussen systemen en leefwereld. Hij legt de nadruk op het belang dat in de moderne samenleving wordt gehecht aan reflectie, zowel voor het voortbestaan van instituties als voor de ontwikkeling van de individuele identiteit. Kennis-claims zijn a-priori altijd van tijdelijke aard, morele- religieuze- opvattingen kritiseerbaar. Veel van wat vroeger zekerheid verschafte, komt op losse schroeven te staan. Als een van de kenmerken van de moderne tijd beschrijft Giddens het hernieuwd zoeken, door individuen en groepen, naar zingeving en moraliteit. Waar Habermas de nadruk legt op het communicatieve handelen en aanstuurt op een machtsvrije dialoog, gebruikt Giddens de term life-politics. Hij geeft daarmee aan dat, hoewel door de systeemwerking ethiek en morele regels hun vanzelfsprekende zeggingskracht verliezen, individuen worden geconfronteerd met existentiële vragen, met morele problemen en het maken van keuzen. Het ontstaan en de ontwikkeling van de palliatieve zorg in Nederland is een voorbeeld van een proces dat begon met onvrede over bestaande situaties en de keuze voor kwaliteit van zorg tegenover een overmaat aan belangstelling voor behandeling en genezen.

Het belang van communicatie voor het omgaan met en interpreteren van situaties en ervaringen wordt met hulp van Giddens, maar ook aan de hand van Van Asperen, Begeman en Kunneman van kanttekeningen voorzien. Niet alles is in woorden te vatten, niet alles is altijd bespreekbaar. Mensen kunnen belemmeringen binnen en buiten zichzelf ervaren om in woorden uit te drukken en van gedachten te wisselen over wat hen bezig houdt. Een onderwerp dat in het derde hoofdstuk terugkomt.

$\mathrm{Na}$ het bespreken van de theorieën van Giddens en Habermas, wordt vanuit maatschappijtheoretisch gezichtpunt ingegaan op de palliatieve zorg, haar doelstellingen en ontstaansgeschiedenis in Nederland. Reden hiervoor is dat het verschijnen en de ontwikkeling van deze zorgvoorziening een goed voorbeeld is van de interferentie systeem-leefwereld en van life-politics.

\subsection{De 'onoplosbare' spanning tussen systeem en leefwereld}

De snelle ontwikkelingen op het gebied van techniek, wetenschap en globalisering, vanaf het midden van de vorige eeuw, waren de stuwende kracht van de 
modernisering van de maatschappij tot in de kleinste vezels. Een ontwikkeling die nog steeds gaande is, niet alleen in Nederland, maar in alle geỉndustrialiseerde en kapitalistische landen. Het is belangrijk iets van deze achtergronden te schetsen om het ontstaan van de palliatieve zorgverlening in Nederland te kunnen plaatsen.

Belangrijk kenmerk van de moderne tijd is haar controlemechanisme, de mogelijkheid tot interne reflectie en bijsturing. Moderne organisaties, de moderne staat als zodanig, zijn dynamische systemen. Nieuwe kennis en ervaringen, die van binnenuit of van buitenaf, worden gesignaleerd, worden geanalyseerd en ingezet om de organisatie, de staat, in stand te houden en aan te passen aan nieuwe situaties. Dit in tegenstelling tot de periode waarin traditie, feodalisme en hiërarchie sturende krachten waren. De ontwikkelingen van de moderne tijd zijn volgens Habermas (I98I) een gevolg van rationaliseringsprocessen binnen de leefwereld, leerprocessen die in de loop van de sociale evolutie, vanaf de 16 de en r7de eeuw hebben geleid tot de differentiatie van verschillende geldigheidsaanspraken ten opzichte van elkaar (Kunneman, 1986). Een mogelijkheidsvoorwaarde om over de waarheid van uitspraken, juistheid van normen en oprechtheid van personen communicatieve overeenstemming te bereiken. Aan het begin van de moderne tijd maakte deze ontwikkeling, die zich vooral op cultureel niveau afspeelde, de verzelfstandiging mogelijk van theoretische discussie in wetenschappelijke instituties. Zo ontstonden in de I6de en I7de eeuw een rechtssysteem en een daarmee corresponderend normatief bewustzijn, met een universalistische structuur (Kunneman, I986. p.244). Tegen deze achtergrond maakt Habermas het rationaliseringsproces van de leefwereld, het ontstaat van aparte subsystemen en de daaruit voortvloeiende spanning tussen beide werelden, de leefwereld en de systeemwereld, duidelijk.

Met het begrip leefwereld verwijst Habermas naar het onproblematische vanzelfsprekende kader van waaruit mensen elkaar ontmoeten en begrijpen. Het is een omvattend kader, bron van betekenissen waaruit mensen putten in de omgang met elkaar en met de wereld. Elementen van dat vanzelfsprekende kader kunnen ter discussie worden gesteld, daarover kan men van mening verschillen, maar nooit het hele kader. De leefwereld betekent een onmisbaar décor, het verschaft hulpbronnen die mensen nodig hebben om uitingen en ervaringen van zichzelf en anderen te kunnen interpreteren en tot gezamenlijke werkelijkheidsdefinities te kunnen komen.

Interpretatiekaders zijn niet de enige bron waarover de leefwereld beschikt. Habermas (Kunneman, 1986) wijst op twee andere hulpbronnen van de leefwereld, de gedeelde normen en de beschikbaarheid van toerekeningsvatbare personen. De structuur van de leefwereld bestaat uit cultuur, maatschappij en 
persoon. Deze drie componenten zijn noodzakelijk voor zowel het welslagen van communicatie en het realiseren van overeenstemming, als voor maatschappelijke solidariteit en het in standhouden van de individuele identiteit van de mensen die daarvan deel uitmaken. Kortom, voor de kwaliteit van het bestaan in de huidige samenleving. Waarheid van argumenten, gedragen door de cultuur waarin mensen samenleven; juistheid van normen, gebaseerd op legitieme maatschappelijke ordening; en waarachtigheid van intenties, gedragen door competentie, vormen de rationele motivatie van handelingsplannen van de moderne mens.

Genoemde bronnen zijn voorwaarden voor ongestoord communicatief handelen, omgekeerd worden deze bronnen ververst en in stand gehouden door dat communicatieve handelen. Beide zijn van elkaar afhankelijk en nodig voor wat Habermas de symbolische reproductie van maatschappijen noemt. Symbolische reproductie, verbonden met communicatieve rationaliteit.

Om het begrip systeemwereld uit te leggen verwijst Habermas naar de noodzaak van materiële reproductie voor het voortbestaan van mens en maatschappij(en). Naast symbolische reproductie vindt ook materiële reproductie binnen de leefwereld plaats. De rationalisering van de leefwereld is niet compleet, er zijn gebieden, waar niet het communicatief handelen, maar het strategisch handelen het sturend en in standhoudend mechanisme is. Dit handelen is gericht op processen waarbij de materiële wereld geproduceerd en gereproduceerd wordt. Het zijn gebieden die zich hebben verzelfstandigd tot systemen, zoals de economie met haar marktmechanisme en de staat met zijn politieke systeem. Zij vloeien voort uit het rationaliseringsproces dat de verhoudingen en communicatie binnen de leefwereld transparant maakt, tegen een achtergrond van gedeelde opvattingen, maar tegelijk ruimte creëert voor de verzelfstandiging van deze systemen. Niet communicatieve overeenstemming, maar geld en macht zijn binnen de systeemwereld werkzame prikkels bij het realiseren van doelstellingen en het instandhouden van bureaucratische organisaties en kapitalistische verhoudingen. De materiële reproductie is verbonden met cognitief instrumentele rationaliteit en doelgericht handelen. Symbolische reproductie en de materiële reproductie hebben zich in de moderne maatschappijen van elkaar verzelfstandigd.

Ook de ontwikkeling van wetenschap en techniek, die gepaard gaat met steeds verdergaande specialismen, leidt tot subsystemen, waar mensen een eigen taal spreken en het alledaagse bewustzijn, de leefwereldrationaliteit, nauwelijks toegang heeft. Deze deskundologische subculturen leiden tot fragmentatie van de leefwereld en het verloren gaan van zingevende kaders (Kunneman, 1986). Communicatieprocessen, noodzakelijk voor de symbolische reproductie van de leefwereld, worden door de ongelijke verhoudingen die eigen zijn aan de 
structuur van de systeemwereld, geblokkeerd. Habermas gebruikt hiervoor de term kolonisering van de leefwereld. Het probleem is de paradox die uit de rationalisering van de leefwereld ontstaat omdat zij enerzijds leidt tot transparante verhoudingen en communicatief handelen, maar tegelijk noodzakelijke voedingsbodem is voor het ontstaan van subsystemen. Gebieden die, geblokkeerd van het alledaags bewustzijn, in stand worden gehouden door doelrationeel strategisch handelende individuen en organisaties. Hierdoor ontstaat een spanning, een kloof tussen de wereld waar mensen samenwerken en die waar mensen samenleven. Habermas definieert dit probleem als onoplosbare spanningsverhouding tussen democratie en kapitalisme (Kunneman, 1986): binnen de Westerse maatschappijen gingen het rationaliseringproces en de verzelfstandiging van systemen gepaard met asymmetrische verhoudingen en sociale ongelijkheid. Economie en staat putten voor hun functioneren uit de hulpbronnen van de leefwereld, die arbeidskrachten levert en de bereidheid van mensen te gehoorzamen aan de regelingen en aanwijzingen vanuit het staatsapparaat, zodat het bestuur effectief en intact blijft. Een interferentie die de leefwereld aantast en tegelijk binnen die leefwereld een tegenbeweging oproept in de vorm van emancipatie-, milieu- en vredesbewegingen. Deze tegenbewegingen leggen op rationele wijze de bedreiging van de moderne ontwikkelingen bloot, die voornamelijk vanuit het systeemdenken als vooruitgang gezien worden.

Rationele motivatie is volgens Habermas uiteindelijk afhankelijk van argumentatie, onverenigbaar met dwang en manipulatie. Slechts met behulp van wat Habermas een ideale gesprekssituatie noemt, kunnen argumenten worden verhelderd. Dit vereist communicatief symmetrische verhoudingen tussen betrokkenen, individuen die vrij met elkaar omgaan en zichzelf kunnen zijn. Waar Habermas wijst op de kolonisering van de leefwereld door systeemdwang, gaat Giddens in op de potenties die in de leefwereld aanwezig zijn. En waar Habermas het communicatietheoretisch perspectief en de kwaliteit van communicatieve verhoudingen benadrukt, gaat Giddens (200I) in op het hernieuwd zoeken van groepen en individuen naar zingeving en moraliteit. Giddens' maatschappijtheorie sluit aan bij die van Habermas. In 'Modernity and Self-Identity' (2001), brengt Giddens de mechanismen van de huidige tijd ('the Late Modern Age') in kaart. Haar verworvenheden en kwetsbaarheden, alsmede de impact ervan niet alleen op organisaties maar ook op het individu en de individuele verantwoordelijkheid.

Het meest karakteristieke van de moderne tijd is, volgens Giddens, haar extreem dynamisch karakter. Giddens noemt drie mechanismen die deze dynamiek voeden. Dat is in de eerste plaats de scheiding van tijd en ruimte. Vroeger waren de plaats waar je ter wereld kwam en de tijd waarin je leefde, voor een 
belangrijk deel bepalend voor wie je was en hoe je leven zou verlopen. Moderne communicatietechnieken, mogelijkheden van transport en gebruik van media, hebben ertoe geleid, dat nieuwe kennis, invloeden en ervaringen van buiten, mensen gemakkelijk en overal bereiken. Hierdoor is de wereld toegankelijker geworden voor grote groepen mensen. Met alle gevolgen van dien. De combinatie van tijd en plaats is niet meer doorslaggevend voor het al of niet handelen en functioneren van organisaties en individuen. Communicatie binnen een organisatie en coördinatie van werkzaamheden is niet langer afhankelijk van de plaats waar men zich bevindt. Een voorbeeld in de gezondheidszorg is monitoring op afstand van patiënten aan hartbewaking- of andere medisch-technisch noodzakelijke apparatuur. Uitwisseling van vragen en ervaringen van specialisten op het internet, patiënten die via dat kanaal artsen consulteren of een bibliotheek bezoeken voor informatie. Een gevolg hiervan is, aldus Giddens (2001, p.r7 ev.), dat sociale instituties diffuus zijn geworden doordat sociale relaties uit hun lokale context kunnen treden om in de onbepaaldheid van tijd en ruimte nieuwe kennis en ervaring op te doen en nieuwe betekenis krijgen.

Hiermee introduceert Giddens de tweede factor die de dynamiek van de moderne tijd voeding geeft, namelijk het mechanisme van abstracte uitwisselingssystemen, zoals geld en specialistische kennis, 'symbolic tokens' en 'expert systems'. Geld is een gestandaardiseerde waarde-eenheid waardoor transacties, onafhankelijk van tijd en plaats mogelijk zijn. Individuen die fysiek nooit met elkaar in contact zijn geweest, kunnen via dit wereldwijde systeem op economische basis met elkaar onderhandelen en zaken doen. Expertsystemen zijn bronnen van kennis en kunde die, onafhankelijk van tijd en ruimtelijke bepaaldheid, geldig en beschikbaar zijn.

De gezondheidszorg ontsnapte niet aan de dynamiek van de moderne tijd. Hattinga Verschure (200I, p. 9) beschrijft hoe door economische welvaart, specialisaties, medische en technische ontwikkelingen, de voorzieningen in de gezondheidszorg enorm toenamen. Ook andere terreinen als die van specialistische kennis ten aanzien behandeling en medicatie van ziekten, waren onderdeel van dat proces. Zoals kennis ten aanzien van de behandeling van gewassen, van de bodem, van drinkwater en van vee als grondstoffen voor voeding. Wetenschap is zo specialistisch geworden dat niemand over kennis en overzicht van het geheel beschikt. Daarom is het gebruik van al deze kennis, op het niveau van organisaties zowel als van individuen, vooral gebaseerd op (blind) vertrouwen, aldus Giddens.

Een derde mechanisme dat de dynamiek van het leven in de huidige tijd bewerkstelligt, is het doorgaande proces van reflectie en van verandering. Dit betekent dat kennis steeds als voorlopig wordt opgevat. Deze reflexieve werking maakt het mogelijk nieuwe ideeën en nieuwe inzichten ruimte te geven 
door bestaande opvattingen aan te passen en zo vernieuwingen door te voeren. Een mechanisme dat herkenbaar is in moderne instellingen en in de organisatie van de maatschappij. In de gezondheidszorg bijvoorbeeld in het doorgaande proces van aanpassingen in beleid, reorganisaties in de zorg, herdefiniëring van doelstellingen en van de betekenis van ziekte en sterven in de huidige maatschappij.

\subsection{Mogelijkheden en problemen van de moderne tijd}

Hebben de voortschrijdende ontwikkelingen veel goeds gebracht in de behandeling van vroeger dodelijke ziekten, de moderne gezondheidszorg kampt met nieuwe problemen. Ook Giddens ziet het probleem, de spanning die het uit elkaar groeien van kennissystemen en het ervaren in de leefwereld met zich meebrengt. Het 'tweesnijdend zwaard' van moderne ontwikkelingen biedt nieuwe en goede mogelijkheden voor de mensheid, brengt daarnaast echter ook nieuwe risico's mee. De teloorgang van kleine gemeenschappen bijvoorbeeld. Gemeenschappen waar families generaties lang samenwoonden maken plaats voor grotere en onpersoonlijker vormen van samenleven en werken (Giddens, 200r, p.33). Binnen de gezondheidszorg zijn veel nieuwe mogelijkheden ontwikkeld, nieuwe therapieën en nieuwe technieken om mensen beter te maken. In veel gevallen betekent dat een verbetering. Tegelijk ontstaan er nieuwe problemen: spanningen tussen zorgvraag en zorgaanbod, een nijpende wachtlijstproblematiek, schaarste aan professionals en vrijwillige zorgverleners en morele vragen verbonden met deze ontwikkelingen en nieuwe mogelijkheden.

De voor de moderne tijd kenmerkende reflectie en de daarmee gepaard gaande dynamiek van voortdurende kennisvermeerdering en aanpassing, is vooral gericht op meetbare, rationele kennis, op het beheersen van 'natuurlijke' processen. Of, in Habermas' termen, op materiële reproductie en systeembouw. Met uiteindelijk doel de onderwerping van de natuur aan menselijke doeleinden. In de periode voorafgaande aan deze 'verlichte tijd' waren traditionele normen en waarden, religie en hiërarchische verhoudingen de samenbindende en in stand houdende krachten van de samenleving. In de huidige tijd waarin kennis macht wordt genoemd, spreken deze oude waarden niet langer vanzelf. Wat aan de ene kant winst oplevert, betere leefomstandigheden, betere gezondheid, mobiliteit en democratische verhoudingen, gaat paradoxaal genoeg samen met verlies van zekerheden. Vaststaande opvattingen maken niet langer een onbetwist en geïntegreerd deel uit van sociale relaties. Net als rationele kennis worden ook deze waarden 'voorlopig' en objectiveerbaar. 
Ethiek wordt een apart gebied, dat in moeilijke situaties kan worden geraadpleegd door experts te consulteren.

\subsubsection{Het individu in de moderne samenleving}

De dynamiek van moderne expertsystemen vindt zijn weerslag in de dynamiek van het leven van individuen. Het leven wordt meer en meer bevrijd van externe banden. Familierelaties die lang helpend, zo niet bepalend waren in het plannen van de levensweg, verliezen die functies. Omdat het traditionele netwerk van mensen die konden voorzien in bepaalde zorgtaken diffuus is geworden, is het individu steeds meer op zichzelf aangewezen in het plannen en realiseren van zijn of haar leven (Giddens, 200r, p.I47). Anderen zijn en blijven altijd belangrijk, maar zorg voor elkaar spreekt niet langer vanzelf, het netwerk moet steeds worden onderhouden en de zorg of hulp georganiseerd. Daarbij spelen bureaucratische regels, de regels van instellingen en overheid, een steeds indringer rol in het dagelijks leven van mensen. De processen van specialisatie en institutionalisering hebben bepaalde ervaringen van het dagelijks leven afgezonderd. Gebeurtenissen die vroeger deel uitmaakten van het dagelijks ervaren, zijn object geworden van wetenschap en instituties. Ziekte en dood, geboorte, seksualiteit, criminaliteit, omgang met de natuur, horen evenals vroeger bij het leven, maar zijn meer en meer afgezonderd in aparte domeinen.

Positivistische opvattingen waren leidraad voor dit afzonderen en versnipperen van ervaringen in aparte kennis- en expertsystemen. De met die gebieden samenhangende morele dimensies raakten vervreemd van het individu en van de samenleving. Ook dat werd het domein van experts. De leefwereld raakte meer en meer gefragmenteerd. Privé en publiek ontwikkelden zich als gescheiden terreinen. Deze versnippering bracht een verlies aan zekerheden mee. Op den duur ontnam ze individuen de mogelijkheid nog de juiste woorden te vinden voor hun eigen ervaringen op die terreinen, om met direct betrokkenen na te denken over de betekenis ervan in het eigen leven en om te gaan met bepaalde gevoelens of situaties. Dit verwijderd raken van eigen morele bronnen, leidde tot gevoelens van betekenisloosheid en existentieel isolement (Giddens, 2001).

In haar boek 'Het bedachte leven', wijst ook Van Asperen (r993) op dit probleem. De moderne tijd ontbeert een gemeenschappelijk zingevingskader. De discussie over de zin van het bestaan in het licht van de eindigheid is uit het publieke discours verdwenen. In de pluralistische cultuur is dat een privé-zaak geworden. leder individu is op zichzelf aangewezen in het zoeken en vinden 
van zin en betekenis van zijn of haar leven. Het is moeilijk geworden, aldus Van Asperen, over kwetsbaarheid te praten. $\mathrm{Zij}$ noemt dit de 'privatisering van het leed' en stelt dat er niet langer een gedeeld vocabulaire beschikbaar is. Van Asperen pleit ervoor weer een gemeenschappelijke taal te vinden om existentiële vragen opnieuw aan de orde te stellen en daar publiekelijk over te kunnen spreken. Zij wijst op het belang van de traditie als gemeenschappelijk kader. Niet iedereen eigent zich vanuit de traditie dezelfde waarden toe, maar het is die achtergrond die keuzen mogelijk maakt en mensen levensvormen aanreikt, aldus Van Asperen.

Op het belang van traditie voor het verstaan en begrijpen van de eigen levenssituatie en het maken van keuzen gaat ook Begeman (1995) in. In zijn boek beschrijft hij de hulpverlening aan slachtoffers van de Tweede Wereldoorlog en de morele dilemma's daarvan. Om voor hulp in aanmerking te komen moeten slachtoffers hun recht op hulp legitimeren op basis van de rationele criteria van het hulpverleningssysteem. De emotionele gevolgen, de morele en existentiële problemen de zij ervaren, datgene waaronder zij het meeste lijden, moeten zij 'vertalen' in financiële problemen. Daardoor dreigt het gevaar dat zij vervreemd raken van zichzelf en afhankelijk worden van anderen. Aan de hand van de hermeneutiek van Gadamer en Habermas maakt Begeman duidelijk dat een gemeenschappelijke traditie onontbeerlijk is in het verstaan en begrijpen tussen hulpverleners en slachtoffers. Alleen vanuit een gemeenschappelijk kader is het mogelijk het perspectief van de ander te begrijpen en te leren van nieuwe ervaringen.

Niets afdoend aan de zegeningen van de moderne tijd, is een van haar effecten dat het nadenken over de zin en de betekenis van bijvoorbeeld lijden en eindigheid, buiten de directe context van het eigen leven werd geplaatst. Ervaringen met de dood komen vaak en veel de privé-wereld binnen via media als krant en televisie en maken zo, onproblematisch, deel uit van het leven van elke dag, terwijl directe confrontatie met de dood psychologisch een groot probleem is geworden. De dood krijgt een 'soap'-gehalte: de media scheppen een beeld dat als werkelijk wordt ervaren, maar dat niet overeenstemt met de realiteit waarmee mensen uiteindelijk worden geconfronteerd. 'In conditions of modernity, in sum, the media do not mirror realities but in some part form them' (Giddens, 200I, p.27). Dood wordt het moment waar menselijke controle eindigt. Het wordt een technisch onderwerp, een medische zaak. Wat dood is, wordt bepaald door het meten van lichaamsfunctie en besluitvorming over het stoppen van behandelen. Het spreken over de betekenis van sterven, spreken over eindigheid, kwetsbaarheid en dood, is vreemd en moeilijk geworden. 'Death remains the great extrinsic factor of human existence...'(Giddens, 200I, p.162). 


\subsubsection{Life-politics}

Waar Habermas verklaart dat de rationalisering van de leefwereld niet compleet is, doordat de zich ontwikkelde zelfstandige subsystemen niet op communicatieve wijze transparant worden, benadert Giddens het probleem van de spanning tussen systeem en leefwereld van de andere kant. Hij zet uiteen dat het vervreemdende effect dat mechanismen van de moderne tijd op mensen uitoefenen, niet volledig en onomkeerbaar is.

De dynamiek van de moderne tijd heeft, naast het marginaliseren van de rol van het individu binnen het geheel van expertsystemen, ook de ideeën van menselijke emancipatie bevorderd. Niet alleen door rationele kritiek op de hiërarchische rol van traditie en religie en door de democratische ordening van de maatschappij vanuit morele opvattingen over rechtvaardigheid, gelijkheid en participatie. Het los komen staan van traditionele waarden en normen, de snelle veranderingen, nieuwe mogelijkheden en risico's waarmee de samenleving voortdurend wordt geconfronteerd, vraagt van mensen dezelfde reflexiviteit als die van moderne organisaties: een voortdurende herbezinning en het zoeken naar eigen antwoorden op existentiële vragen die nieuwe (levens)ervaringen en crisissituaties oproepen. De dynamiek van de moderne tijd is werkzaam in zowel het afzonderen van moraliteit in rationele expertsystemen als in de emancipatie van het individu en zijn en haar zoeken naar nieuwe antwoorden op morele vragen.

Voor dit zich opnieuw present stellen van morele vragen in de veranderende wereld en het zoeken van individuen naar nieuwe antwoorden, introduceert Giddens (200I) het begrip life-politics. Waar de emancipatoire politiek van de moderne samenleving is gericht op gelijke kansen, gaat het bij life-politics om het maken van keuzen. In zijn definitie zegt Giddens (2001, p.124): 'Life-politics concerns political issues which flow from processes of self-actualisation in posttraditional context, where globalising influences intrude deeply into the reflexive project of the self, and conversely where processes of self-realisation influence global strategies.' Het gaat om politiek bewustzijn en zelfverwerkelijking in een posttraditionele context, waar mondiale invloeden de zelfreflectie beïnvloeden en waar omgekeerd het reflexieve proces van zelfverwerkelijking van individuen invloed uitoefent op mondiaal beleid. Met politiek heeft Giddens twee betekenissen voor ogen, een smalle opvatting en een bredere. De smalle betekenis verwijst naar beleid en beslissingen over rechten en plichten op overheidsniveau, de bredere betekenis van politiek doordringt (in de laat-moderne tijd) alle besluitvormingsprocessen die gebaseerd zijn op de uitkomsten van discussies of conflictsituaties waarin tegengestelde belangen of waarden in het geding zijn. Belangrijk kenmerk van de life-political agenda is dat het gaat om het zoe- 
ken naar antwoorden op confrontaties met specifieke morele vragen en dilemma's en het stellen van existentiële vragen die door de moderne tijd zijn onderdrukt.

Life-politics valt niet samen met emancipatie en vloeit er ook niet automatisch uit voort. Emancipatie is wel een voorwaarde ervoor: 'Life-politics' - concerned with human self-actualisation, both on the level of the individual and collectively emerges from the shadow which 'emancipatory poltics' has cast.' (Giddens, 200I, p.9). Emancipatie houdt in dat het collectief op zo'n manier wordt georganiseerd dat het individu op één of andere wijze in staat is tot vrij en onafhankelijk handelen in zijn of haar sociale leven. Vrijheid en verantwoordelijkheid in balans: 'Freedom presumes acting responsibly in relation to others and recognizing that collective obligations are involved' (Giddens, 200I, p.213). Life-politics gaat verder. Het gaat over beslissingen die voortvloeien uit die (keuze)vrijheid. Het betreft onderwerpen als zelfidentiteit en moraliteit. Het gaat om het kiezen en creëren van moreel te rechtvaardigen vormen van leven, van werken en van samenleven van individuen die lokaal en mondiaal met elkaar te maken hebben. Hier komen de door Giddens genoemde belangrijke elementen in beeld waarop deze life-political keuzen betrekking hebben. Dat is in de eerste plaats de vorming van de eigen identiteit. In de moderne tijd is dat een reflexief proces. De eigen persoonlijkheid is als een verhaal - 'narrative of self-identity', dat wordt gevormd, veranderd en reflexief ondersteund als antwoord op de snel veranderende omstandigheden van het sociale leven. Zowel op lokaal niveau als wereldwijd. De morele weg van zelfverwerkelijking is die van authenticiteit, gebaseerd op 'waar' en 'echt' zijn voor jezelf (Ibid. p. 78). Alleen als de persoon in staat is een innerlijke authenticiteit te ontwikkelen - een basis van vertrouwen waardoor hij of zij in staat is eigen het leven (het levensverhaal) en dat van anderen te begrijpen als een eenheid tegen de achtergrond van de veranderende gebeurtenissen - kan dit worden bereikt. Vanuit dit perspectief is life-politics verbonden met discussie en strijd, voortvloeiend uit het reflexieve project van de vorming van de eigen identiteit (Ibid. p.215). Een proces dat ook lichamelijke processen en ontwikkeling betreft. Evenmin als de persoonlijkheid kan ook het lichaam (of de lichamelijkheid) gezien worden als een vaststaande fysiologische eenheid. Ook het lichaam is opgenomen in de reflexiviteit die de moderne tijd kenmerkt: reflexive appropriation of bodily processes and development is a fundamental element of life-political debates and struggles.' (Giddens, 2001, p.218). Vanuit life-political perspectief moet het individu keuzen maken, beslissingen nemen ten aanzien van het eigen lichaam. Giddens verwijst onder meer naar biologische reproductie en reproductie-technologie, naar de mogelijkheid van het individu om zaken die met lichaam en lichamelijke ontwikkeling te maken hebben te plannen en in te passen in het eigen levensverhaal. Hij noemt ook 
abortus en de vraag van wanneer, in welk stadium we van een persoon spreken. Identiteit en lichamelijkheid zijn met elkaar verbonden.

Life-politics stelt vragen bij het doorgaande dynamische proces van reflectie en verandering binnen expertsystemen. Vanuit de emancipatoire invloeden en bewegingen van de moderne tijd, maakt life-politics de grenzen zichtbaar van beslissingen die uitsluitend worden beheerst door interne, rationele criteria. Life-political onderwerpen zijn bedoeld om wat door de systemen is onderdrukt, weer in het centrum van de aandacht te plaatsen. Omdat het daarbij gaat om vragen over 'hoe te leven in geemancipeerde sociale omstandigheden' kan het niet anders dan gaan om vragen van morele en existentiele aard (Giddens, 2001, p.224).

Voorbeelden van groepen die zich hebben georganiseerd en zich strijdbaar opstelden om rechten als vrijheid, rechtvaardigheid en gelijkwaardigheid te verdedigen, zijn onder andere de milieubeweging, de vredesbeweging, de vrouwenbeweging, en de homobeweging. Tegelijk werden en worden vanuit deze bewegingen life-political vragen gesteld over de definitie van de individuele identiteit: 'wat, wie wil ik zijn' en 'hoe (goed) te leven'. Existentiële- en morele vragen die door mechanismen van de moderne tijd worden onderdrukt, worden op deze manier door individuen of groepen opnieuw naar voren gebracht en op de politieke agenda geplaatst. Giddens (200I, p.23r) wijst er op dat niet onderschat moet worden hoe moeilijk het is die keuzen te maken en vragen te formuleren die een persoonlijk en maatschappelijk proces van verandering op gang brengen. Er is moed voor nodig om uit de sociale bedding van de traditie, waarin rolpratronen en opvattingen vastliggen, te stappen en zichzelf en anderen vragen te stellen over identiteit en verantwoordelijkheid. Het is een project dat is verbonden met discussie en strijd. Giddens illustreert dit aan de hand van de geschiedenis van het feminisme. 'For in liberating themselves from the home, and from domesticity, women were faced with a closed-off social environment.'(Ibid. 2r6).

De identiteit van vrouwen was zo verbonden met huis en haard, dat zij daarbuiten slechts voorbeelden tegenkwamen van sociale beddingen die alleen beschikbaar waren voor mannen. $\mathrm{Zij}$ moesten iets nieuw beginnen. Het stellen van vragen over de eigen indentiteit, eigen waarden en de behoefte tot zelfverwerkelijking werd daarmee van eminent belang.

Ook de palliatieve zorg-beweging die in Nederland begin jaren negentig binnen en buiten de gezondheidszorg op gang kwam uit onvrede over de technische en gemedicaliseerde zorg voor stervenden, is een voorbeeld van een beweging die nieuwe aandacht opeiste voor ethiek en kwaliteit van zorg.

Of de spanning tussen leefwereld en systeem voldoende wordt opgelost door 
Giddens' life-politics, of dat ook deze tegenbewegingen zich op den duur voegen in of ontwikkelen tot nieuwe, zelfstandige systemen die zich weer afzonderen uit het dagelijks bewustzijn en daarmee het probleem onoplosbaar blijft, is de vraag. Een vraag ook met betrekking tot de palliatieve zorgbeweging.

\subsection{Maatschappijtheoretische begrippen van Habermas en Giddens in relatie tot de palliatieve zorg}

Giddens' maatschappijtheorie sluit aan bij die van Habermas. Habermas maakt duidelijk dat het ontstaan van moderne, kapitalistische maatschappijen gepaard gaat met rationalisering van de leefwereld, het ontstaan en een voortdurende uitbreiding van subsystemen met een eigen rationaliteit (Widdershoven, 1987 , p.122 ev.). Modernisering moet volgens Habermas begrepen worden als een samenhang van processen op systeem en leefwereld niveau. Habermas spreekt van rationalisering wanneer leefwereldstructuren veranderen onder invloed van leerprocessen. De rationalisering van de leefwereld wordt in gang gezet door systeemproblemen, en leidt op haar beurt tot systeemvorming (Ibid. p.127). Problemen ontstaan wanneer systeemmechanismen vormen van sociale integratie gaan verdringen op gebieden waarin handelingscoördinatie via de communicatieve weg niet gemist kan worden. Habermas' theoretisch eindpunt van de maatschappelijke ontwikkeling is 'een ideale communicatie gemeenschap', waarin er samenhang is tussen individuele en maatschappelijke emancipatie. Zijn theorie gaat uit van een principiële mogelijkheid van een evenwichtig samengaan van cognitief-instrumentele, moreel-praktische en expressieve rationaliteit. Een integratie die wordt bevorderd door het ontstaan van tegenbewegingen, die een overdreven nadruk op één geldigheidsaanspraak ter discussie stellen (Ibid. p.r3o).

Giddens plaatst zijn notie van life-politics in het kader van modenisering 'As mentioned previously, the concerns of life-politics presage future changes of farreaching sort: essentially, the development of forms of social order 'on the other side' of modernity itself.' (Giddens, 200I, p.2I4). Giddens onderschrijft Habermas' ideaal van een gemeenschap waarin sprake is van vrije en ongestoorde communicatieve verhoudingen, als een platform, als basisconditie voor emancipatoire politiek (Ibid. p. 213). Emancipatie is voor Giddens eveneens van belang en is mogelijkheidsvoorwaarde voor life-politics. Waar volgens Habermas systeemvorming enerzijds spanningen oplevert door het uit elkaar groeien van cognitief instrumentele en communicatieve rationaliteit, is diezelfde spanning anderzijds aanleiding tot leerprocessen in de leefwereld die mensen in staat stelt een eigen identiteit te ontwikkelen en zich tegenover anderen te presente- 
ren als toerekeningsvatbare personen (Widdershoven, 1987, p.126). Deze gedachte wordt door Giddens uitgewerkt in het begrip life-politics, dat mogelijkheden biedt tot het creëren van moreel te verantwoorden vormen van leven die de ontwikkeling van een eigen-identiteit bevorderen in de context van het lokale en het globale en tegen de achtergrond van de intern referentiele systemen van de moderne tijd.

Het onstaan van de palliatieve zorg in Nederland en in andere delen van de wereld, kan gezien worden als een voorbeeld van de door Habermas genoemde 'tegenbewegingen' en van Giddens' life-politics. Deze ontwikkeling kan geduid worden als een emancipatie proces van bewustwording en losmaking uit het systeem, een protest tegen al te instrumentele verhoudingen in de zorg voor stervenden. Centraal staat het stellen van morele en existentiële vragen in over 'hoe te leven' en 'hoe zorg te dragen' voor mensen in de laatste fase van hun leven. Palliatieve zorg is een vorm van life politics, die zich richt op het ontwikkelen van moreel verantwoorde vormen van leven en daarbij behorende identiteiten binnen de context van zich (snel) veranderende sociale omstandigheden, lokaal en wereldwijd. Dat vereist de ontwikkeling van (nieuwe vormen van) communicatie, die verder reiken dan enkel talig redeneren. Om morele en existentiële onderwerpen en vragen aan de orde te stellen en op de (politieke) agenda te houden, moet men kunnen putten uit verhalen van mensen die het aangaat, kunnen beelden en gedichten een gevoeligheid wakker maken die onderdrukt was en waar men geen woorden aan kon geven en bieden principes aanknopingspunten deze te verbinden met concrete situaties en ervaringen. Palliatieve zorg kan zo beschouwd worden als een voorbeeld van life politics. Dat sluit niet uit dat er een spanningsvolle verhouding bestaat tot het systeem (van de gezondheidszorg). Enerzijds probeert men vormen van communicatie te ontwikkelen die zich aan het systeem onttrekken; anderzijds is een inbedding in het systeem (met de bijbehorende financiële mogelijkheden) een noodzakelijkheid. De precaire situatie van de palliatieve zorg is daarmee een voorbeeld van de precaire situatie van de leefwereld en van life politics in onze samenleving.

\subsection{Palliatieve zorgbeweging}

De ontwikkeling van de palliatieve zorg kan worden gezien als een recent voorbeeld van de werking van life-politics. De zorg voor mensen in de laatste fase van hun leven werd op de politieke agenda geplaatst als resultaat van de dynamiek van verschillende invloedssferen: de gezondheidszorg en medische wetenschap als reflexief georganiseerde systemen, de ervaringen en existentië- 
le vragen van individuen die betrokken waren bij de zorg voor stervenden, en de invloeden die zich van buitenaf (van buiten Nederland) lieten gelden.

De nota van het Ministerie van Volksgezondheid Welzijn en Sport (VWS) van april 200I, 'De zorg voor het levenseinde in Nederland', begint met de zin: Het medisch handelen rond het levenseinde is al dertig jaar ondenverp van maatschappelijk debat in Nederland. In dat debat is altijd plaats geweest voor de vraag hoe om te gaan met het weloverwogen verzoek van de uitzichtloos en ondraaglijk lijdende patiënt aan zijn arts om euthanasie. Jaren van discussie over euthanasie gingen vooraf aan de ontwikkeling van palliatieve zorgverlening en de zogenoemde hospicebeweging. Een optiek van waaruit het accent wordt gelegd op kwaliteit van zorgverlening, en van waaruit men het spreken over de betekenis van sterven en lijden weer een plek wil geven in het leven van mensen. Begin jaren negentig ontstonden de eerste zogenoemde 'bijna-thuis-huizen' en hospices. $\mathrm{Na}$ de aarzelende beginperiode schoten de hospice-voorzieningen als paddestoelen uit de (hard)vochtige, door technische vooruitgang overschaduwde gezondheidszorggrond. Onderstaand een recent overzicht waaruit blijkt, dat er op dit moment ruim 375 bedden, verdeeld over I03 instellingen in Nederland beschikbaar zijn (Francke, 2003). Van een erkenning volgens de Wet Ziekenhuisvoorzieningen (WZV) is vooralsnog geen sprake. In afwachting daarvan vindt financiering plaats door per instelling afspraken te maken met het betreffende Zorgkantoor (brief College voor Zorgverzekeringen (CVZ) aan Zorgkantoren, 200I), overheveling van gelden bestemd voor Intensieve Thuiszorg (ITZ-gelden) en middels het fenomeen zwevende bedden in verpleeghuizen, die uit de Algemene Wet Bijzondere Ziektekosten (AWBZ) worden gefinancierd. Een belangrijke bron van financiering vormt het particulier initiatief door middel van fondsenwerving en de inzet van talloze vrijwilligers in de ondersteuning en uitvoering van de zorgverlening. Om tot een definitieve regeling en erkenning van voorzieningen op het gebied van de palliatieve zorg te komen, werd door de minister van Volksgezondheid, Welzijn en Sport de projectgroep Integratie Hospicezorg geïnstalleerd. De projectgroep kreeg de taak deze zorg in het reguliere aanbod te integreren (Conceptnota Projectgroep, 1999). Hiertoe werden modellen voor de praktijk ontwikkeld, die in pilot-projecten werden getoetst. De projectgroep zou in oktober $200 \mathrm{I}$ haar eindrapport aan de minister aanbieden (Brief minister Borst, oktober 2000). Inmiddels werd een werkgroep aan de projectgroep toegevoegd om te adviseren over de bekostiging van de palliatieve zorg. Een werkgroep bestaande uit deskundigen uit kringen van zorgverzekeraars, de thuiszorg, hospice-afdelingen bij verpleeg/verzorgingshuizen, ziekenhuizen, 'bijna-thuis-huizen' en zelfstandige hospices. Deze heeft haar advies in juli 2001 aan de projectgroep uitgebracht en in het werkveld bekend gemaakt (Werkgroep bekostiging van de 
projectgroep integratie hospicezorg, juni, 200I). Al met al ziet het er naar uit, dat op niet al te lange termijn de palliatieve zorg in Nederland, erkend en geregeld zal zijn.

Schema instellingen met palliatieve zorgvoorzieningen (Francke, 2003)

\begin{tabular}{|c|c|c|}
\hline Soorten Instellingen: & Aantal instellingen: & Aantal bedden: \\
\hline Bijna-thuis-huizen & 21 & 61 \\
\hline Zelfstandige hospices & 16 & 85 \\
\hline Verpleeghuizen & 37 & 152 \\
\hline Verzorgingshuizen & 26 & 60 \\
\hline Ziekenhuizen & 3 & 17 \\
\hline
\end{tabular}

\subsubsection{Het systeem van de gezondheidszorg in Nederland}

'Zorg voor mensen in een gezonde samenleving' is het motto van het Ministerie van Volksgezondheid, Welzijn en Sport volgens de Memorie van Toelichting op de begroting van het jaar 2001 .

De Nederlandse overheid neemt niet ziekte of zorg als uitgangspunt van gezondheidszorgbeleid, maar gezondheid (Boot en Knapen, 200I). Preventie van ziekte, bescherming en bevordering van gezondheid zijn daarvan de pijlers. Het stelsel van gezondheidszorg in Nederland is gebaseerd op tripartiete samenwerking: particulier initiatief, verzekeraars en overheid zijn verantwoordelijk voor een sluitend geheel van voorzieningen. De zorgsector wordt grotendeels gefinancierd door middel van verzekeringen, met name de ziekenfondsverzekeringen, de Algemene Wet Bijzondere Ziektekosten en de particuliere ziektekostenverzekeringen. De overheid draagt zorg en verantwoordelijkheid voor de uitvoering van de collectieve zorg (preventie, promotie en protectie), terwijl het particulier initiatief zorg draagt voor de uitvoering van individuele zorg (medische en verpleegkundige zorgverlening). De individuele zorg wordt betaald uit verzekeringspremies, de collectieve zorg uit belastinggelden (Boot en Knapen, 2001). Op basis van politieke overwegingen stelt de overheid grenzen en regels op om ook op het terrein van de particuliere zorg sturend te kunnen optreden en mede verantwoordelijkheid te dragen voor aanbod, toegankelijkheid en kwaliteit van zorgvoorzieningen.

De regeling van de aansluiting van het zorgaanbod aan de zorgvragen vindt plaats door middel van het zogenaamde erkenningenstelsel. Voor de financie- 
ring door de Algemene Wet Bijzondere Ziektekosten en de Ziekenfondswet, heeft elke instelling een erkenning van de overheid nodig. Om hiervoor in aanmerking te komen moet de instelling voldoen aan kwaliteitseisen ten aanzien van de voorzieningen en diensten. De minister geeft de erkenning na advisering door het College voor Zorgverzekeringen (Boot en Knapen, 2001). In die erkenning worden de capaciteitsgegevens geregistreerd, geregeld in de Wet Ziekenhuis Voorzieningen; deze worden vervolgens vertaald naar het budget van de instelling volgens het richtlijnenstelsel van de Wet Tarieven Gezondheidszorg.

Deze planmatige bemoeienis van de overheid was er niet altijd. De economische en maatschappelijke ontwikkelingen na de Tweede Wereldoorlog en de snelle groei van medische en technologische kennis droegen bij aan het klimaat van overheidszorg voor het collectieve welzijn. Dit door planmatig ingrijpen in het economisch leven en door belastingpolitiek. Was het bijvoorbeeld vroeger zo dat huisartsen zich vrij konden vestigen en religieuze groeperingen ziekenhuizen konden bouwen wanneer men dacht daar goed aan te doen, tegenwoordig geldt een stringent vestigingsbeleid dat door de overheid wordt gereguleerd.

Daarnaast was er een sterk hiërarchisch onderscheid tussen bestuurders, artsen en andere werkers in de gezondheidszorg, zoals verpleegkundigen (Hattinga Verschure, 2001). Ook dat beeld is verouderd.

\subsubsection{Palliatieve zorg, een leefwereld binnen het systeem van de gezondheidszorg}

De zorg voor mensen die niet meer kunnen genezen heeft zich 'los'gemaakt uit het systeem van de gezondheidszorg, in de praktijk waarvan behandelen, genezen, techniek en beheersen belangrijker zijn dan inleven, begrijpen, begeleiden en luisteren.

De ontwikkelingen van de moderne tijd hebben een kloof veroorzaakt tussen het op genezen gerichte handelen (cure) en het verzorgend aspect van die behandeling (care). Waren beiden vroeger nauw met elkaar verweven, door de 'vooruitgang', het positivistisch denken verbonden met het belang dat in de moderne tijd wordt gehecht aan objectiveerbare kennis en meetbare resultaten, zijn het meer en meer aparte tradities, aparte werelden geworden, waar een andere taal wordt gesproken en andere normen gelden. Bij cure gaat het erom de ziekte op alle mogelijke manieren en met inzet van beschikbare mensen en middelen, de baas te worden. Bij care gaat het om de relatie van mens tot mens. Ook in de cure-wereld is de stem van de patiënt doorslaggevend. Hij 
of zij bepaald zo mogelijk steeds zelf al dan niet in te stemmen met een bepaalde behandeling. Het is echter steeds de professional die informatie verschaft en die met het oog op de ziekte, de strategie aangeeft en de behandelwijze voorstelt. Het systeem van de gezondheidszorg regelt de beschikbaarheid, de tijd (wachtlijsten), de kosten en financiering en bewaakt de kwaliteit van het medisch (cure) handelen.

Hoewel de kloof niet al te letterlijk moet worden genomen, en er in beide werelden elementen van zowel cure als care aanwezig zijn, wil ik met het onderscheid belangrijke accentverschillen duidelijk maken:

\section{Care}

symptomen verzachten

met het oog op kwaliteit van leven aandacht voor sociale omgeving en existentiële vragen

open houding

luisteren

begrijpen, verstaan

de tijd nemen

ondersteund door vrijwilligers

veel particulier initiatief

algemene middelen + fondswerving

\section{Cure}

symptomen controleren met het oog op herstel van de ziekte

weinig aandacht voor sociale omgeving existentiële vragen spelen nauwelijks rol instrumentele houding uitleggen diagnose en behandeling woekeren met beschikbare tijd 'professionals only' deel van het systeem algemene middelen (verzekeringsstelsel)

Het effect van het uit elkaar groeien van beide gebieden, is dat het begrijpen, het zichzelf en elkaar verstaan steeds moeilijker wordt. Hierdoor kunnen mensen van zichzelf, van hun eigen leefwereld vervreemd raken: verpleegkundigen, artsen en andere professionele zorgverleners die in hun werk te maken hebben met moeilijke situaties van mensen door ziekte, pijn en lijden, met de belasting van ingrijpende behandelmethoden, maar ook met morele- of existentiële vragen. Vragen, waarop zij bij zichzelf en bij elkaar niet altijd adequate antwoorden vinden. Of patiënten, die hun ervaringen niet louter in symptomen kunnen uitleggen en meer behoefte hebben aan begrip en menselijke nabijheid dan opnieuw een chemokuur. En familie van ongeneeslijk zieke mensen die geen klankbord heeft voor de zorgen en de leegte die zij ervaren. Begeman (1995) wijst erop dat het voor zowel professionele zorgverleners als voor zorgvragers belangrijk is, aansluiting te zoeken bij een belevingswereld die zij beiden verstaan. De professionele zorgverlener moet hiervoor inspanningen doen, door bijvoorbeeld niet te snel vanuit de eigen professie en de eigen opvattingen de verhalen van de patiënten te begrijpen, maar een her- 
meneutische houding aan te nemen om door te kunnen dringen in wat anders is, wat ontroert en verwondert. Hieruit ontstaat een dialoog waarin de vervreemding overwonnen kan worden en begrip kan groeien (Begeman, 1995).

\subsubsection{Opnieuw de spanning tussen systeemeisen en leefwe- reldverwachtingen}

Hoewel de palliatieve zorg is ontstaan uit onvrede met het systeem waarbinnen de zorg voor stervenden beschikbaar was, is het niet zo dat de palliatieve zorg buiten dat systeem kan functioneren. Dit brengt een bepaalde spanning met zich mee. Door institutionalisering van de palliatieve zorg zal de zorg onder druk komen van systeemeisen. Om als (palliatieve) voorziening beschikbaar te zijn voor ieder die dat nodig heeft en te steunen op structurele financiering uit algemene middelen, zal moeten worden voldaan aan de eisen van het Nederlandse systeem van gezondheidszorg. Dit zal spanning met zich meebrengen om niet ten prooi te vallen aan mechanismen als bureaucratisering en communicatieve onmacht door rationalisering van emotionele en existentiële ervaringen.

Begeman (1995) betoogt dat voor een gelijkwaardige communicatie tussen mensen uit verschillende invloedssferen, waarbij ook vaak verschillende belangen op het spel staan, het een noodzakelijke voorwaarde is te zoeken naar een gemeenschappelijke traditie en taal. In zijn onderzoek maakt hij dit concreet door zijn oefening in de 'dubbele hermeneutiek'. Dit stelt eisen aan de kwaliteit van onderlinge communicatie: een open houding, gericht op het begrijpen van de ander (het andere) en de bereidheid herhaaldelijk de eigen zienswijze te problematiseren. De spanning tussen het leefwereldperspectief van de palliatieve zorg en het perspectief van de systeemwereld van de gezondheidszorg waarbinnen zij zich een plaats heeft verworven kan worden verhelderd en wellicht overbrugd door een dialoog waarbij de leefwereldervaringen opklinken en aansluiting zoeken bij de heersende traditie, waardoor beide zich verder kunnen ontwikkelen zonder van zichzelf vervreemd te raken.

\subsection{Grondslagen van de palliatieve zorgverlening en ontstaansgeschiedenis}

Vele vormen van zorgverlenen zijn geïnstitutionaliseerd. De institutionalisering onttrok de zorg voor een groot deel aan de leefwereld. De gezondheidszorg werd gesystematiseerd, methodisch georganiseerd en gecontroleerd door 
rationele regels en professionele kennis en motieven. Daardoor moesten mensen hun zorgbehoeften vertalen in termen van de systeemwereld: geld, macht en recht, zij dreigden vervreemd te raken van de emotionele en existentiële behoeften die aan hun zorgvraag ten grondslag lagen (Begeman, 1995).

De gezondheidszorg kent verscheidene aandachtsgebieden. Veel specialismen, die met elkaar zijn verbonden, maar die tegelijk door de snelle toename van kennis en (alternatieve) mogelijkheden soms aparte werelden lijken te zijn. Behalve verschillende aandachtsvelden, is er ook verschil in aanpak, in benadering en doelstellingen binnen de gezondheidszorg, ook binnen dezelfde disciplines van specialistische kennis (Giddens, 2000, p. 139 ev.). De kennis van leken is toegenomen, kennis is gemakkelijker beschikbaar gekomen door techniek en wetenschap. Mensen zijn mobieler en gemakkelijker in staat daar hun heil te zoeken waar zij denken die te kunnen vinden.

De gezondheidszorg is grofweg onderverdeeld in drie gebieden. De preventieve-, curatieve en palliatieve zorgverlening of geneeskunde. De term 'geneeskunde' maakt duidelijk wat de meeste aandacht krijgt, dat is het genezen, mensen die ziek zijn weer beter maken.

Palliatie ('verzachting') en ook preventie, belangrijke peilers van het beleid van de overheid (Boot en Knapen, 20or), zijn meer uit het zicht van de samenleving gebleven. $\mathrm{Zij}$ spreken ook minder tot de verbeelding, laten minder gemakkelijk spectaculaire resultaten zien. Toch is in Nederland, in het bijzonder gedurende het laatste decennium, een verandering op gang gekomen in de beeldvorming van wat gezondheidszorg, cq. geneeskunde toevoegt aan de waarde van 'het goede leven'. Enerzijds werd dit proces op gang gebracht doordat door de ontwikkeling van medische mogelijkheden de kosten van gezondheidszorg hoog opliepen. Daarnaast werden steeds meer morele problemen die met de snelle ontwikkeling van de geneeskunde verband hielden, publiekelijk aan de orde gesteld. Waar medische problemen werden opgelost, kwamen er vaak morele voor in de plaats en werden en worden ethici ingeschakeld om uitkomst te bieden (Van Asperen, 1993, Dupuis, 1998). De nadruk op de soms oneindig lijkende mogelijkheden van de medische wetenschap is volgens Van Asperen mede oorzaak van het verdwijnen van zingevende kaders die het nadenken over de eindigheid en kwetsbaarheid van mensen richting geven. Het medische bedrijf lijkt een symbool geworden van de hoop de sterfelijkheid te kunnen uitstellen. In de confrontatie met crisissituaties van zichzelf of anderen, breken de zingevingsvragen door het pantser van deze beheersbaarheid en vervreemding van de eigenheid van mensen heen en zoeken naar antwoorden of wegen om er mee om te gaan.

Naast de mogelijkheden van herstel en genezen, werd kwaliteit van leven tijdens en na ingrijpende therapieën een belangrijk aspect van afweging voor arts 
en patiënt voor wel of niet verder (be)handelen. Naast de medische- kwam de zorgrelatie meer en meer in het vizier, de begrippen cure en care en de balans daartussen, werden onderwerpen op de agenda's van werkers in de gezondheidszorg en van beleidsmakers. Ervaringen uit de leefwereld eisten ruimte op binnen het systeem van de instellingen van gezondheidszorg.

In dit klimaat ontstond de aandacht voor palliatieve zorgverlening. Probeerde men in de beginperiode, eind jaren tachtig, begin jaren negentig, vooral het Engelse 'hospice-model' na te volgen, tegenwoordig is men er meer op gericht de zorg in te passen in de structuren van de Nederlandse gezondheidszorg, passend in de Nederlandse situatie. Hoewel palliatieve zorg geen nieuw begrip is, ontstond toch een geheel nieuwe ontwikkeling, een professionalisering van de zorg, die gericht is op mensen die ongeneeslijk ziek zijn én de mensen die hen direct omringen. Een ontwikkeling die gepaard gaat met een proces van maatschappelijke openheid en bewustwording van de kwetsbaarheid en eindigheid van mensen.

De ontwikkeling van deze zorg begon ongeveer 35 jaar geleden in Engeland, met name door Dame Cicely Saunders, een verpleegkundige die later arts is geworden en zich het lot van stervenden heeft aangetrokken. Op het gebied van pijnbestrijding en aandacht voor ook andere dan alleen de fysieke aspecten van mensen die ongeneeslijk ziek zijn, heeft zij de ogen van velen die haar navolgden geopend. In dezelfde periode werd ook door Elisabeth Kübler-Ross, Amerikaans psychiater, de aandacht gevestigd op de noden en behoeften van de stervenden. Zij heeft veel bekendheid gekregen door haar model van 'stervensfasen', waardoor meer inzicht en begrip ontstond voor psychologische processen van verlies en rouw. Ook zij staat aan de wieg van wat nu is uitgegroeid tot een niet meer weg te denken aandachtsgebied in de zorgverlening, de palliatieve zorg, zowel in Amerika als in West- en Oosteuropa (Kübler -Ross, I970; Saunders, 1993).

In plaats van de term palliatieve zorgverlening wordt regelmatig hospicezorg gebruikt.

Hoewel met hospicezorg hetzelfde wordt bedoeld als palliatieve zorg, kan dit door elkaar gebruiken van begrippen tot verwarring leiden. Het ontstaan van de term hospicezorg heeft te maken met een diepere laag in de ontstaansgeschiedenis van de huidige palliatieve zorg. Al in de vroege Middeleeuwen kende men de hospices, waar pelgrims, op weg naar Rome en Jeruzalem, onderdak en verzorging vonden. Hospitium betekent gasthuis. Kloosters en abdijen die in Europa op een bepaalde route op dagmars afstand van elkaar waren te vinden, hadden de taak op zich genomen gastvrijheid en zorg te verlenen aan mensen onderweg. Deze hospices bleven bestaan tot ver na de late Middeleeuwen, toen hun taak werd overgenomen door artsen en ziekenhui- 
zen. De traditie van de hospices werd aan het eind van de negentiende eeuw opnieuw opgepakt door de Ierse 'Sisters of Charity'. Dit uit onbehagen met de manier waarop in ziekenhuizen werd omgegaan met ongeneeslijk zieke patiënten. Het eerste hospice, gesticht door deze zusters, werd in 1879 in Dublin geopend. Het initiatief van deze beweging vond navolging en ook in Engeland ontstonden hospices waar ongeneeslijk zieke mensen werden verzorgd. De zorg in die periode was vooral gericht op de psychosociale en spirituele behoeften van mensen. De mogelijkheden en de ontwikkelingen van pijnbestrijding kwamen pas na de jaren vijftig op gang, in de praktijk gebracht door Cicely Saunders. In dit klimaat richtte zij uiteindelijk St. Christophers Hospice in Londen op. Daarmee begon zij de moderne hospice beweging, waarin een breed concept van palliatieve zorg werd ontwikkeld (Janssens, r999).

Palliatief komt van het Griekse 'pallium', wat mantel betekent. Palliatieve zorg is gericht op het verzachten van het lijden. Vaak wordt de verbinding gelegd met Martinus, de Romeinse soldaat en latere bisschop van Tours in de derde eeuw na Christus, die voor de poort van Amiens een zieke bedelaar zag zitten. Hij sneed zijn mantel in tweeën en gaf de ene helft aan de schaars geklede bedelaar met de woorden 'Ik kan u niet beter maken, maar u hoeft geen kou te lijden.'

\subsubsection{De begrippen}

De Wereldgezondheidsorganisatie (WHO) geformuleerde in 1989 de volgende definitie: Palliatieve zorgverlening is de actieve totale zorg - lichamelijk, emotioneel, sociaal en spiritueel - voor patiënten die ongeneeslijk ziek zijn en degenen die hen direct omringen. Het doel van de zorg is het bereiken van de best mogelijke kwaliteit van leven voor zowel de patiënt als zijn familie (Doyle, 1993). Deze definitie wordt gehanteerd in het inmiddels brede scala van palliatieve zorgvoorzieningen.

Wanneer de palliatieve fase in het ziekteproces begint, zal van situatie tot situatie verschillen. Wanneer echter duidelijk is dat genezing redelijkerwijs niet meer mogelijk is, zal alle zorg erop gericht zijn het leven dat de patiënt nog rest zo draaglijk mogelijk te laten zijn voor hem of voor haar en degenen in de directe nabijheid. De intentie van zorg verschuift van het genezen naar het bieden van een zo goed mogelijke kwaliteit van leven.

De verschillende begrippen die in de definiëring van de WHO worden genoemd, vragen om verdere verduidelijking. Het begrip zorg, is een van de eerste om bij stil te staan, zorg en zorgverlenen. 
Bij het spreken over zorg en zorgverlenen, is er sprake van een zorgvraag en er zijn zorgaanbieders. Kenmerkend voor het zorgverlenen in de gezondheidszorg cq. palliatieve zorg, is dat het steeds gaat om zorg ten aanzien van een andere persoon of personen. Het verlenen van zorg, ook het ontvangen ervan, is een relationeel- en een intentioneel proces, waarin, naast professionele- en organisatorische regels en kenmerken van de zorg, morele opvattingen, emotionele en sociale belevingen van de mensen waar het in de praktijk om gaat, een rol spelen. Reflectie op het handelen en op de ervaringen die men in de praktijk van de zorgverlening opdoet, een klimaat waarin communicatie vrij en open is, zijn daarmee belangrijke voorwaarden van zorgverlenen.

Palliatieve zorg is professionele zorgverlening. Een concept dat verwijst naar (specialistische) kennis en kunde en liefdevolle aandacht. Liefdevol heeft te maken met een houding en een bereidheid de behoefte van de ander centraal te stellen en de eigen inzichten en ervaringen te delen, gericht op goede zorgverlening.

Palliatieve zorg is ook actieve zorg. Dit begrip heeft te maken met een actieve houding van alertheid en openheid voor problemen en (zorg)behoeften die zich in de praktijk kunnen voordoen. Daarbij gaat het er niet alleen om deze signalen op te merken. Het gaat er om er iets mee te doen, ook preventief, om pijn of eventuele problemen te voorkomen.

$\mathrm{Bij}$ het begrip totale zorg, gaat het om het totaal, het geheel, gesymboliseerd door het woord pallium, mantel. De totale zorg omringt de zieke als een mantel. Het gaat daarbij niet alleen om de fysieke gevolgen van ziekte. Natuurlijk is dit wel heel belangrijk, pijn en symptoombestrijding zijn primaire aandachtspunten. Pijn en andere fysieke problemen kunnen een alles overheersende rol spelen. Primair zal de aandacht er dan ook op gericht zijn pijn en andere nadelige gevolgen van de ziekte en de behandeling te verzachten. Echter het grootste probleem is niet altijd pijn of lichamelijk ongemak, bovendien wordt de pijnbeleving beīnvloed door tal van andere zaken (Van Orshoven en Menten, 1996).

De palliatieve zorg richt zich ook op die andere aspecten van het omgaan met het naderend levenseinde. Angst en onzekerheid, vragen over zin en betekenis van lijden en sterven, zijn belangrijke aandachtsgebieden. Hierbij richt men zich niet alleen tot de ongeneeslijk zieke, maar ook tot de mensen om hem of haar heen. Kortom, naast het fysieke- zijn ook de psychische-, de spirituele- en sociale aspecten van het menszijn onderdeel van aandacht en zorg. Het begrip totale zorg verwijst ook naar het samenwerken met andere zorgverleners en andere disciplines. In de palliatieve zorg is veel aandacht voor dit multidisciplinair samenwerken. Zorg wordt gezien als teamwerk. Men kan elkaar ondersteunen in de zorgverlening door het uitwisselen van ervaringen, het signale- 
ren van problemen en het onderzoeken van mogelijkheden. In plaats van de ontwikkeling van de palliatieve zorg tot een aparte discipline, ligt de nadruk op samenwerken, delen van kennis en ervaring, in het licht van kwaliteit van zorg. verlenen.

In de definitie van de WHO gaat het om patiënten die ongeneeslijk ziek zijn. Bij deze categorie van patiënten is in de loop van het ziekteproces geconstateerd dat genezing niet meer mogelijk is. De behandeling/zorgverlening is niet langer gericht op genezen (curatieve fase), maar op verzachten van lijden (palliatie). Wanneer iemand begrijpt, of van de dokter hoort, dat zijn of haar leven binnen afzienbare tijd zal eindigen, heeft dit een grote invloed op de patiënt en zijn of haar directe omgeving. Hoewel iedereen zich tijdens zijn leven realiseert ooit te zullen sterven, is het concrete feit van een ongeneeslijke ziekte een diep ingrijpende ervaring. Het nadenken over de dood heeft vaak betrekking op de dood van iemand anders. Aan het onder ogen zien van de eigen sterfelijkheid komen veel mensen pas in een laat stadium van hun leven toe. Het bericht, ten dode te zijn opgeschreven grijpt diep in in het leven. Praktijk en literatuur laten zien dat het stervensproces steeds een diepe ervaring is zowel voor het individu dat stervende is, als voor de mensen die nauw met hem of haar verbonden zijn. Veel factoren zijn van invloed op de manier waarop met sterven en dood wordt omgegaan. De factor leeftijd bijvoorbeeld kan bepalend zijn in hoeverre men de dood begrijpt en hoe lang men er over heeft kunnen nadenken. Er is een groot verschil tussen hoe kinderen aankijken tegen de dood en hoe volwassenen dat doen. Daarnaast is er de invloed van de persoonlijke levensgeschiedenis en wat mensen geloven: wat gebeurt er na de dood, waaraan heeft men houvast, waaraan ontleent men kracht, welke rituelen zijn belangrijk. Ook de cultuur, de taal en de tijd waarin men leeft zijn van invloed op de betekenis van de dood in het leven van individuele mensen.

In de reguliere zorgverlening is het spreken over en omgaan met de dood een achtergebleven gebied. Er is weinig oog voor het lijden van mensen, buiten het gebied van lichamelijke pijn (Scholberg, 1995). Kenmerkend voor het klimaat waarin genezen en controle de boventoon voeren is dat, voordat de palliatieve zorg in Nederland een plaats veroverde, de discussie over euthanasie al bijna twintig jaar gaande was en werd geregeld in een meldingsprocedure van 1990 (Maas, Van Delden en Pijnenborg, 199r; Van der Wal en Van der Maas, 1996; Ministerie van VWS, 2001).

De geneeskunde, gericht op behandelen en genezen, benadrukt de somatische aspecten van het ziek zijn. Voor veel hulpverleners is de dood een moeilijk bespreekbaar onderwerp. Men heeft hoge verwachtingen van de medische mogelijkheden. Door deze medische en op genezing gerichte houding is de zorg voor ongeneeslijk zieke mensen over het algemeen niet optimaal. Vaak 
lijdt de hele persoon en de mensen in zijn of haar directe omgeving lijden mee. Met de uitdrukking de hele persoon wordt opnieuw benadrukt dat het niet alleen gaat om het lichamelijk lijden of ongemak. Het lijden, de zorgen, zijn velerlei. Naast de confrontatie met pijn of andere symptomen, lijden mensen vaak aan het isolement waarin ze verzeild kunnen raken, aan psychische, spirituele problemen en existentiële vragen.

Het zijn verschillende gebieden, die onderling sterk samenhangen en elkaar beïnvloeden. Mensen stellen zichzelf vragen zoals: "Houdt hiermee nu alles op?", "Is dit het absolute einde van...", "Is de grens tussen leven en dood werkelijk niet te overschrijden?", "Is leven zinloos?". Met die vragen zoekt men de zin en de betekenis van het leven en van de begrensdheid daarvan (Van Osselen, 1997).

Palliatieve zorg is ook op de naasten van de patiënt gericht, familie, vrienden worden bij de zorg betrokken. Dat wil zeggen, zij worden begeleid in de zorg voor en om de patiënt. Voor zover familie zelf voor een stervende wil en kan zorgdragen, zal zij daarbij zo veel mogelijk worden ondersteund, niet alleen thuis, ook wanneer de patiënt wordt opgenomen. Begeleiding is tevens gericht op de rouwverwerking van de naasten.

Nog wat begrippen die niet met name worden genoemd in de eerder beschreven definitie, maar die in de filosofie van de palliatieve zorg besloten liggen, laat ik de revue passeren. In de palliatieve zorgverlening zorgt en handelt men vanuit het bewustzijn dat sterven deel is van het leven. Leven en sterven zijn met elkaar verbonden. Men gaat ervan uit dat mensen de gelegenheid moeten hebben te leven tot het einde. De kwaliteit van het leven dat nog rest staat centraal. Of, zoals Saunders (1990) het noemt 'geen dagen toevoegen aan het leven, maar leven aan de dagen.'

Het ontwikkelen van opleiding en onderzoek behoort tot een van speerpunten van palliatieve zorg. Om de zorg verder te ontwikkelen en uitgangspunten aan te scherpen. In de opleidingstrajecten van werkers in de gezondheidszorg is doorgaans weinig aandacht besteed aan ethiek en aan zorgaspecten die met de dood te maken hebben. Een terrein dat men tot ontwikkeling wil brengen om in de toekomst palliatieve zorg beschikbaar te hebben voor iedereen die dat behoeft. Tenslotte: De praktijk van de palliatieve zorgverlening is tot nu toe niet realiseerbaar gebleken zonder helpend hart en handen van vele vrijwilligers. Daarom is er veel aandacht voor werving en opleiding van mensen die zonder betaling inzetbaar zijn in de palliatieve zorgverlening.

De grondslagen van de palliatieve zorg zijn veelomvattend en ambitieus, verbonden met een diep geworteld idee van wat goede zorgverlening inhoudt. Om deze richtlijnen in de praktijk om te zetten in daden is het noodzakelijk dat ze 
worden gedeeld door de mensen die in de zorg op elkaar zijn aangewezen en de specialisten die daarbij worden ingeschakeld. Ook de patiënt, de zorgontvanger is hierbij betrokken, hem of haar wordt een actieve rol toegeschreven in de manier waarop de zorg wordt georganiseerd en uitgevoerd. Onderlinge communicatie en ethische reflectie spelen hierin een cruciale rol.

\subsection{Samenvatting}

In dit hoofdstuk werd een maatschappelijke ontwikkeling geschetst tegen de achtergrond waarvan de palliatieve zorg zich in Nederland heeft gevestigd. Begonnen werd met het communicatietheoretisch perspectief van Habermas (198I) en de opvattingen van Giddens (200I). Vanuit Habermas' theorie wordt beschreven hoe het rationaliseringsproces van de leefwereld vanaf de $16 \mathrm{de}$ en I7de eeuw, heeft geleid tot verzelfstandiging van processen van symbolische reproductie en die van de materiële reproductie binnen de leefwereld. Hierdoor ontwikkelden zich subsystemen, die niet langer afhankelijk waren van het communicatieve, op overeenstemming gerichte handelen, maar werden geleid door strategisch, doelgericht handelen van individuen en organisaties. Er ontstond een spanning tussen systeemwereld en leefwereld, tussen arbeid en interactie. Dit had tot gevolg dat bepaalde gebieden in de leefwereld niet langer toegankelijk waren voor kritische reflectie en communicatie.

Giddens sluit hierbij aan. Hij gaat met name in op de dynamiek van de moderne tijd en de gevolgen daarvan op individu en samenleving. Waar Habermas de nadruk legt op communicatieve verhoudingen, gaat Giddens in op de werking van life-politics om duidelijk te maken hoe mensen in staat zijn moraliteit en zingeving opnieuw bespreekbaar te maken. Zo kunnen zij een ontwikkeling op gang brengen die de interferentie tussen leefwereld en systemen vanuit de leefwereld organiseert, tegenover de kolonisering vanuit de systemen waar Habermas van spreekt.

De palliatieve zorgbeweging wordt in dit hoofdstuk gepresenteerd als een voorbeeld van de werking van Giddens' life-politics. Tegen de achtergrond van het maatschappijtheoretisch kader wordt vervolgens de palliatieve zorg, het ontstaan en de doelstellingen ervan, uiteengezet.

De spanning tussen systeem en leefwereld, waarop zowel Giddens als Habermas nadrukkelijk wijzen, is ook verbonden met de toekomst van de palliatieve zorg. Zal de palliatieve zorg, waarbij nu nog het relationele aspect, de kwaliteit van communicatie en het nadenken over zin en betekenis centraal staan, haar eigenheid behouden als zij straks zal zijn ingebed in de structuren van het Nederlandse gezondheidszorgsysteem met zijn systeemeisen? 
Ook binnen de ethiek komt deze vraag aan de orde, is er sprake van een verwant spanningsveld als die tussen systeem en leefwereld. In het volgende hoofdstuk wordt dit uiteengezet. 


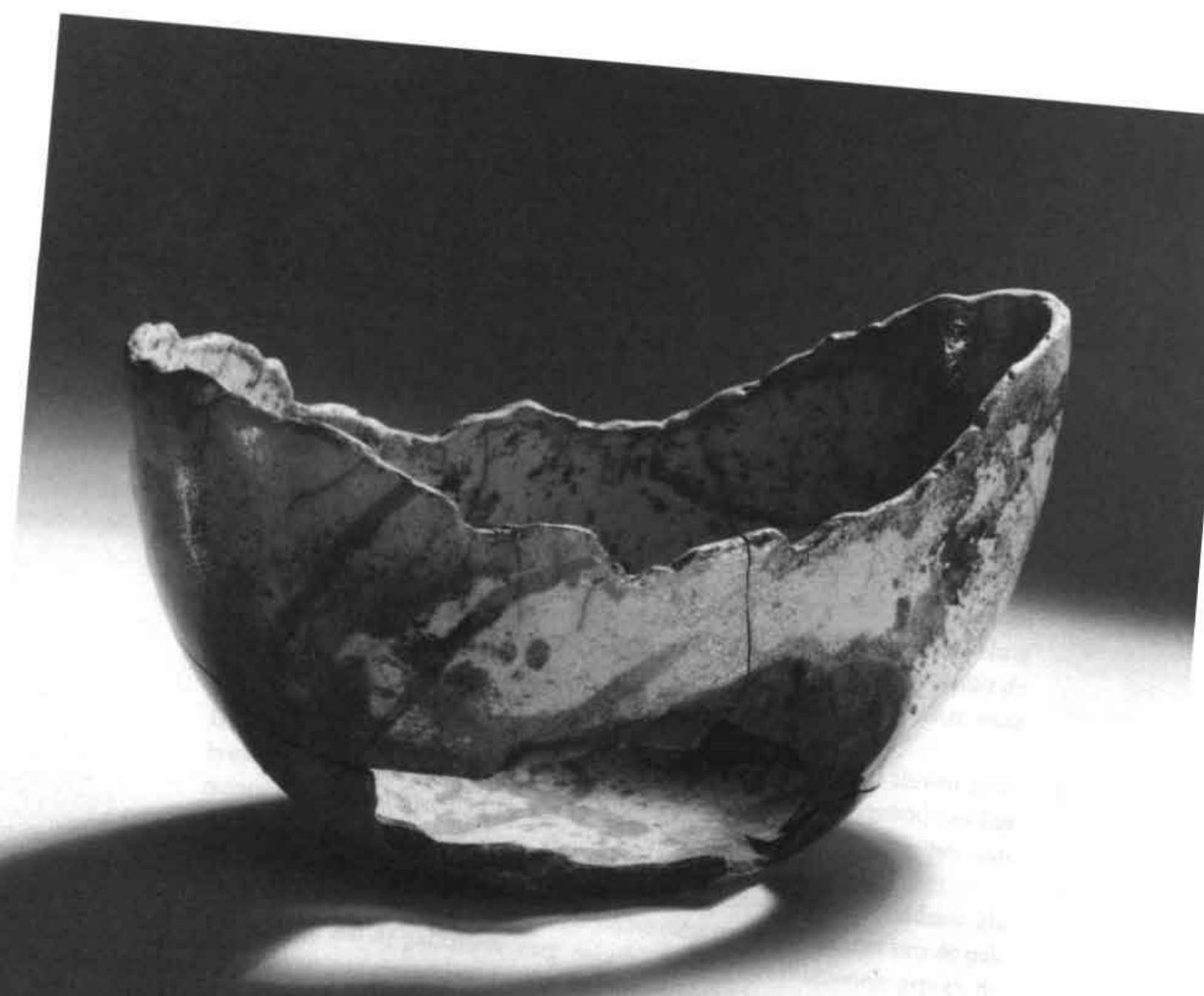


Zijn hoofd rustte op het kussen tussen slangen, buiten zag ik de bange wolken zich samenpakken, als grijze dekens, die het licht bedekten en de tranen tegenhielden.

De moeder schoof het scherm opzij en huilde.

Met zulke wolken is het weer niet moeilijk te voorspellen, dus hielden zij de ogen dicht, ze wilden nog niet weten wat het was. De monitor, het zuchtend apparaat, de dikke regendruppels verbraken de stilte waarin zij stonden. Het was toen al te laat.

Hand in hand telden ze de seconden, de regen kon niet weg, ze roeiden geluidloos verder, op de tast. Wolken wierpen hun last in het water en vervormden de kringen tot herinneringen.

Verslagen gingen zij aan land. 


\section{Ethiek in de spanning tussen systeem en leefwereld}

\subsection{Inleiding}

In het zoeken naar antwoorden op morele en existentiële vragen waar zorgverleners en anderen, die zijn betrokken bij de zorg voor stervenden, meer en meer mee werden geconfronteerd, ontstonden initiatieven om de palliatieve zorg ook in Nederland een plaats te geven (Janssens, 1999). Een proces dat vanaf de jaren zestig gaande was, tegelijk met de opkomst van de nieuwe gezondheidsethiek, als teken van verzet tegen het alsmaar op genezen gericht zijn. In die nieuwe ethiek gaat niet langer alleen om de deugdzaamheid van de arts. Centraler komt de vraag naar het effect van de behandeling op de kwaliteit van leven van de patiënt (Widdershoven, 2000). De patiënt krijgt het recht zelf te beslissen over wel of niet behandelen. De arts biedt hem daartoe de mogelijkheid door zo goed mogelijk te informeren over zijn medische situatie.

Bestonden die eerste initiatieven op gebied van palliatieve zorg aanvankelijk uit kleinschalige projecten, grotendeels gefinancierd door particulier initiatief, op dit moment is ze uitgegroeid tot een niet meer weg te denken zorgvoorziening en staat zij op het punt van integratie als normale voorziening in de door de overheid georganiseerde en gestructureerde gezondheidszorg en het stelsel van zorgverzekeringen. Een ontwikkeling, die zich de laatste tien tot twaalf jaar heeft voltrokken en waar initiatiefnemers, de pioniers van die eerste periode blij mee zullen zijn. Er is inmiddels immers in heel Nederland een breed aanbod van palliatieve zorgvoorzieningen beschikbaar (NPTN, 200I).

De vraag is of het moreel onbehagen daarmee voldoende is bestreden. Om met die nieuwe structuren en daarmee verbonden systeemeisen, niet opnieuw onder de systeemdruk te worden vermorzeld, blijft het belangrijk dat men binnen de palliatieve zorgverlening de uitgangspunten van die zorg levend houdt. Het opnieuw ter sprake brengen, present en centraal stellen van de ethische dimensies van de palliatieve zorg zoals deze zich ontwikkelde binnen de moderne samenleving, kan worden geduid als begin van een life-political proces, zoals Giddens (200I) dat noemt. Om de in gang gezette veranderingen in 
de zorg voor stervenden en de (her)ontdekte waarden in de palliatieve zorg te ondersteunen, is aandacht voor en reflectie op de realisatie van die ethische uitgangspunten van belang.

Dit hoofdstuk gaat over de vraag of er een ethiek is, die de spanning tussen systeemwereld en leefwereld goed uitwerkt. Twee ethisch theoretische stromingen worden voor het voetlicht gebracht, de regelethiek en de zorgethiek. Regelethiek en zorgethiek maken op verschillende manieren duidelijk wanneer er sprake is van een ethisch probleem ${ }^{t}$. De regelethische benadering is een rationele benadering. Problemen worden afgewogen op basis van regels en principes. Vanuit de zorgethische benadering gaat het om zorgverlening als proces. Een proces dat bestaat uit vier met elkaar samenhangenden fasen, die verschillende morele waarden veronderstellen. In dat proces neemt communicatie een belangrijke plaats in. Bij het uiteenzetten en vergelijken van beide benaderingen gaat het erom helder te maken hoe zij staan in het spanningsveld tussen systeem en leefwereld en te laten zien wat de sterke en kwetsbare punten zijn van de afzonderlijke stromingen.

\subsection{De regelethiek}

De regelethiek wordt uiteengezet door aan te knopen bij de dynamiek van de moderne tijd, de veranderingen in de gezondheidszorg, de medische ethiek en de daarmee verbonden opvattingen van autonomie en emancipatie. Om vervolgens in te gaan op de morele uitgangspunten van de regelethiek en, aan de hand van een situatie uit de praktijk, het daarmee verbonden 'stappenplan'. Wat de regelethiek te bieden heeft, haar sterke en kwetsbare kanten in het spanningsveld tussen systeem en leefwereld wordt in de daarop volgende paragraaf uiteengezet.

\subsubsection{De nieuwe gerichtheid van ethiek in de gezondheidszorg}

De snelle ontwikkelingen van de moderne tijd hebben ertoe bijgedragen dat traditionele opvattingen betwijfelbaar werden en onder kritiek gesteld.

1 De begrippen ethiek en moraal worden in de praktijk en ook in de literatuur vaak door elkaar gebruikt. Beide begrippen zijn betrokken op een stelsel van normatieve regels binnen een cultuur, die betrekking hebben op wat het goede leven is, wat goede zorg is, etc. Moraal is dan het stelsel van normen en waarden dat richting geeft aan het denken en handelen, terwijl reflectie, het zich bezinnen op die regels, en het voorstellen van bepaalde veranderingen, het terrein is van de ethiek (Korthals, 1983; Van Thiel en Van den Hoven, 1999) 
Hiërarchische relaties zijn minder vanzelfsprekend, autonomie is een belangrijk uitgangspunt. De laatste decennia staat vanuit ethisch perspectief de autonomie van de patiënt centraal (Beauchamp en Childress, 1994; Ten Have, 1998). In Nederland is het belang van dit perspectief neergelegd in de wet Geneeskundige Behandelingsovereenkomst, in 1995 . De patiënt moet, na volledig te zijn geïnformeerd, zelf beslissingen nemen over verdere behandeling of afzien van medisch ingrijpen. De autonomie, in het perspectief van de regelethiek, is gebaseerd op de liberale opvatting van zelfbeschikking en nietinmenging. Zij wijst elke vorm van sociale sturing af als het gaat om de manier waarop mensen beslissingen nemen over de invulling van hun bestaan (Ten Have, 1998). Deze opvatting van autonomie wordt ook wel negatieve vrijheid of minimalistische ethiek (een minimum waarover iedereen het eens is) genoemd. Het gaat erom dat het een verantwoordelijkheid van de zorgverlener is, de patiënt te behoeden voor inmenging van buitenaf en respect op te brengen voor zijn autonomie, in de zin van zelfbeschikking (Ten Have; 1998 Widdershoven, 2000b).

De veranderingen in de gezondheidszorg waren het effect van voortgaande rationalisering van de relatie mens en maatschappij, een ontwikkeling waarin hiërarchische structuren plaats maakten voor meer individualistische en open verhoudingen binnen de samenleving. De verschuiving in de gezondheidszorg van de weliswaar niet 'almachtige', maar vaak wel 'alwetende' professional naar de 'autonome patiënt' is van grote invloed geweest op de waardering en beoordeling van ethische problemen (Van Osselen, 1997). Deze veranderende opvattingen vonden hun weerslag in ethiek in de praktijk en in ethische theorievorming. Het Hippocratische waardensysteem ${ }^{2}$ werd aangevuld met morele grondbeginselen van de moderne tijd (Ten Have, 1998; Widdershoven, 2000 b). Een ethiek van regels en universele principes om enerzijds de positie van de patiënt te waarborgen, en anderzijds de grenzen, de rechten en plichten van artsen te regelen, werd van toepassing op de gezondheidszorgpraktijk. De rechten en plichten waarnaar de principes verwijzen zijn bindend voor het denken en handelen van betrokkenen in de praktijk, tenzij in individuele situaties sprake is van verschillende met elkaar in strijd zijnde belangen. Het zijn basale uitgangspunten, waarvan betekenis en reikwijdte in concrete situaties steeds weer onder woorden moet worden gebracht en doordacht op hun consequenties (Van Willigenburg, 1998). Dit doordenken vindt plaats door een geordende afweging te maken tussen de vragen die vanuit de verschillende in het geding zijnde principes worden gesteld. Welk principe de doorslag geeft, zal

2 In de Hypocratische traditie lag de nadruk op de deugdzame houding van de arts. De arts was verplicht altijd het belang van de zieke voorop te stellen. En alles te doen wat naar zijn of haar oordeel in het belang was van de patiënt (Widdershoven, 2000). 
steeds afhangen van de specifieke context waarin ethische vragen ontstaan. Om tot een juiste afweging te komen, zullen regelethici ethische probleemsituaties in eerste instantie vereenvoudigen door het probleem te expliciteren als een conflict tussen een of meer van die principes. Vervolgens zullen zij het probleem analyseren met behulp van een stappenplan, of een beslissingsmodel, om daaruit af te leiden hoe het probleem op te lossen of er mee om te gaan (Van Willigenburg, 1998; Widdershoven, 2000b).

\subsubsection{Principes en stappenplan}

In de gezondheidszorg nemen regelethische principes, naar het model van Beauchamp en Childress, een belangrijke plaats in. Dit model staat voor de volgende morele uitgangspunten:

I Het principe van beneficence, of weldoen, houdt in de praktijk van de zorgverlening de verplichting in goed te doen.

2 Het principe van non-maleficence, of niet schaden, betekent dat men risico's zo veel mogelijk moet vermijden en moet nagaan welke belasting of schade, naast het goede dat wordt beoogd, een behandeling mogelijk voor de patiënt met zich meebrengt.

3 Het principe van respect voor autonomy, de verplichting respect te hebben voor de capaciteiten van anderen om zelf beslissingen te nemen.

4 Het principe van justice, van rechtvaardigheid, houdt de verplichting in van een eerlijke verdeling van de mogelijke voorzieningen en van de kosten van de gezondheidszorgvoorzieningen.

De door Beauchamp en Childress geformuleerde principes stammen uit verschillende tradities. Weldoen en het daarmee verbonden uitgangspunt van niet schaden voeren terug naar de opvattingen van Hippocrates. Respect voor autonomie is geworteld in de moderne tijd en is gebaseerd op het principe dat mensen zelf in staat zijn of zo veel mogelijk moeten worden gesteld, om te weten wat goed voor hen is. Ook rechtvaardigheid is de laatste decennia een belangrijk moreel uitgangspunt geworden en verwijst naar het criterium van gelijke behandeling en rechtvaardige verdeling van beschikbare middelen (Ten Have, 1998; Widdershoven, 2000a; 2000b).

Mevrouw Van Wendelen is opgenomen met een zeer ernstige vorm van mammacarcinoom. Zij is 82 jaar oud. Waar normaal het sternum is, vertoont zich een grote wond. Er zijn botmetastasen en hypercalcemie. De patiēnte vindt het 
verschrikkelijk dat ze dood moet gaan, ze zou zo graag nog bij haar kinderen (en kleinkinderen) willen blijven, nog een poosje met hen meeleven. Wat ze mist is vooral het dansen. Ze komt uit een katholiek boerengezin van 14 kinderen. Haar zusje, met wie ze vroeger altijd ging dansen (mogelijk 20 jaar geleden) is ook aan kanker overleden.

Aan de andere kant heeft mevrouw een hekel aan het slikken van medicijnen en aan het ziekenhuis. Men kan haar niet zover krijgen dat ze naar het ziekenhuis gebracht kan worden om daar een foto te maken van haar heup (waar metastasen zitten), laat staan om dit te bestralen. Deze tweeslachtigheid bij haar, herkenbaar voor de kinderen, leidt tot een vrij chaotisch beleid, veel wijzigingen, stoppen en starten van medicatie (bijvoorbeeld voor hypercalcemie). Ze is zeker nog niet terminaal. In het multidisciplinair overleg hebben zorgverleners de mogelijkheid besproken om haar iets meer onder de druk te zetten om de voorgestelde behandeling, zoals bestraling en behandeling van hypercalcemie, te accepteren. Het zou haar de mogelijkheid bieden om langer en met minder klachten te leven. Haar wil om iets te doen aan de heup is echter helemaal verdwenen nadat zij een goed medicament tegen de pijn voorgeschreven kreeg (Oxycontin). Nu ze geen pijn heeft, wil zij niets meer, ook al is er het gevaar van een fractuur.

In concrete praktijksituaties zijn vaak meerdere ethische uitgangspunten in het geding. De ethische uitgangspunten kunnen in verschillende situaties tot verschillende of tegengestelde conclusies leiden, waardoor een ethisch dilemma ontstaat. De principebenadering reikt handvatten aan om in dergelijke situaties tot een meest wenselijke oplossing te komen. Hiertoe is een stappenplan voor ethische reflectie ontwikkeld, een plan dat aangeeft welke stappen binnen een proces van geordend nadenken over een morele vraag kunnen worden onderscheiden (Van Willigenburg, 1998 p.55; Widdershoven, 2000 p. 23).

In de situatie van mevrouw Van Wendelen is het zo, dat zorgverleners een andere opvatting hebben over welke zorg goed is en geboden zou moeten worden dan de patiënte. $\mathrm{Zij}$ hechten grote waarde aan het principe van respect voor autonomie maar vragen zich af: hoever moeten we gaan in het respecteren daarvan? Zij zien mogelijkheden om mevrouw langer te laten leven en de klachten, ook mogelijk toekomstige klachten, te verminderen. $\mathrm{Zij}$ willen het spoor volgen dat mevrouw Van Wendelen in eerste instantie aangaf: wat langer leven, wat langer bij kinderen en kleinkinderen zijn. Zij worden echter, wanneer zij dit aanbod doen, geconfronteerd met een veranderde houding van mevrouw Van Wendelen. Nu zij geen pijn meer heeft, wil ze niets meer.

Om vast te kunnen stellen wat volgens de regelethiek in deze situatie moreel verantwoord is, wordt een het stappenplan gevolgd. Een systematisch plan 
voor ethische reflectie en overleg, dat bestaat uit vier denkbeeldige stappen, die van explicitering, van analyse, van afweging en tenslotte die van het omgaan met de situatie.

\section{Stap 1}

In de situatie van mevrouw Van Wendelen moet duidelijk worden gemaakt dat het verdwijnen van haar wens, haar wil om iets te doen aan de klachten aan haar heup en daardoor langer te leven, een ethisch probleem is voor hulpverleners en niet een psychologisch probleem zoals hoe om te gaan met een patiënt die chaotisch in het leven staat (Widdershoven, 200ob). Het ethisch probleem waar het hier om gaat is:

Is het moreel toelaatbaar om af te zien van de voorgestelde behandeling en de veranderde houding van mevrouw te respecteren, of is het geboden druk uit te oefenen om mevrouw van mening te doen veranderen?

Handelingsmogelijkheden volgens de casus:

- De wens van mevrouw respecteren, zolang ze geen pijn heeft is ze tevreden, wanneer de situatie verandert opnieuw overleggen wat te doen staat;

- Mevrouw confronteren met de risico's van niet behandelen en haar eerdere geuite wens langer te leven en zo druk uitoefenen het professionele advies te volgen.

Stap 2

Dan volgt de analyse van het probleem. Men moet nagaan welke ethische principes in het geding zijn, waar deze principes botsen. Dit vanuit de perspectieven van alle betrokkenen, hier de zorgverleners, de patiënt en haar familie.

De principes die in de situatie van deze mevrouw strijdig zijn met elkaar zijn:

- Het principe van respect voor de autonomie van de patiënt;

- Het principe van weldoen.

\section{Stap 3}

Er moet een afweging plaatsvinden. Dit afwegen is slechts mogelijk door de principes die in het geding zijn nader te onderzoeken, te specificeren wat deze principes of uitgangspunten te zeggen hebben in de concrete situatie van mevrouw Van Wendelen.

Respect voor autonomie is een liberaal beginsel en stoelt op het Igde-eeuwse gedachtegoed van John Stuart Mill. De morele opvatting is, dat het individuele recht van mensen hun leven in te richten naar eigen inzichten, slechts beperkt kan worden als dat de vrijheid van anderen schaadt. Respect voor autonomie wortelt ook in de ideeën van Kant, honderd jaar eerder, over de eigenwaarde van ieder mens en de daarmee samenhangende imperatief mensen nooit lou- 
ter als middel maar altijd als doel op zich te behandelen (Van Willigenburg, 1998).

Respect voor autonomie is in de gezondheidszorg, maar ook daarbuiten, een belangrijk uitgangspunt. Niet alleen ethisch, ook juridisch (WGBO, 1995). Het is in Nederland een algemeen aanvaarde norm dat mensen, na volledig te zijn geinformeerd, zoveel mogelijk zelf moeten kunnen beslissen over het medisch handelen of hun afzien ervan. Deze beslissingen dienen te worden gerespecteerd. Wel kan er in geval van een concreet moreel probleem sprake zijn van een meer of minder autonome keuze. Daarbij komen vragen aan de orde als: is de persoon volledig geïnformeerd, heeft hij of zij tijd heeft gehad om rustig na te denken of staat de persoon onder druk en zijn er omstandigheden die zijn vermogen beslissingen te nemen beïnloeden. Van Willigenburg (I998) onderscheidt vier aspecten van autonomie; er moet sprake zijn van een aanwijsbare keuze of wilsuiting (fysieke competentie), voldoende adequate informatie, vrijwilligheid en psychische competentie.

Naast respect voor autonomie hebben arts en andere zorgverleners te maken met het Hippocratisch uitgangspunt van weldoen. De arts dient alles te doen wat de gezondheid of het welzijn kan bevorderen. Complementair aan dit principe is het uitgangspunt van niet-schaden. Wanneer medisch handelen niet meer zinvol is, niet toevoegt aan de kwaliteit van leven en wanneer eventueel zelfs wordt voorzien dat behandeling meer schade toebrengt dan dat er een goed effect van verwacht zou kunnen worden, heeft dat consequenties voor de arts en zal hij zijn handelen daarop afstemmen.

Het gaat in de casus van mevrouw Van Wendelen om de spanning tussen de plicht tot weldoen en respect voor autonomie. Om tot een juiste afweging te komen, moet van die verschillende principes het gewicht worden aangegeven door na te gaan hoe zij zich in deze concrete situatie tot elkaar verhouden. Men moet nagaan wat weldoen hier precies inhoudt en in welke mate de doelstellingen die de arts daarbij voor ogen heeft kunnen worden gerealiseerd. Daarbij moet tevens worden gekeken naar de eventuele schadelijke effecten. In deze situatie heeft de arts voor ogen de metastasen in de heup te bestralen, waardoor mevrouw van Wendelen mobiel blijft zonder de dreiging van een botbreuk. Tevens wil hij de hypercalcemie behandelen, hetgeen ook zal bijdragen aan haar welbevinden. Mevrouw blijft echter ongeneeslijk ziek en ook de grote wond waar normaal het sternum zit, blijft bestaan en blijft bijdragen aan het lijden en de onomkeerbaarheid van het stervensproces.

$\mathrm{Bij}$ het bepalen wat het principe van weldoen waard is, moet worden nagegaan hoe zwaar de behandeling is voor mevrouw Van Wendelen en welke nadelige bijeffecten van de behandeling te verwachten zijn. Ook moet behandeling van heup en calciumhuishouding in het licht worden gezien van andere klachten, 
die wellicht niet voor behandeling in aanmerking komen. Hoe groot is het goede effect van behandeling, ook in het licht van andere symptomen en klachten? Deze afweging zou het gewicht van het principe van weldoen lichter, minder relevant kunnen maken. Het gewicht van weldoen zou aan de andere kant zwaarder wegen als verwacht mag worden dat de behandeling nauwelijks belastend is en het effect er van wezenlijk bijdraagt tot een langer en beter leven.

Om na te gaan wat het principe van respect voor autonomie in de situatie van mevrouw Van Wendelen betekent, moet worden nagegaan of zij wilsbekwaam is en over voldoende en adequate informatie beschikt (Widdershoven, 200ob). Uit de casus is op te maken dat zij goed in staat is vragen te stellen, informatie te begrijpen en zelf beslissingen te nemen. Weliswaar komt zij nogal tweeslachtig over, wil zij op het ene moment dit en het andere moment weer iets anders. Deze tweeslachtigheid lijkt echter geen verband te houden met de huidige situatie of met haar rationele vermogens, het is een gedragskenmerk dat als zodanig ook door haar kinderen wordt herkend. Haar tweeslachtige karakter heeft haar in het verleden niet belemmerd haar leven in te richten en haar verantwoordelijkheid te nemen voor eigen beslissingen. Het is niet aannemelijk dat dat nu wel het geval zou zijn.

Het specificeren van wat de principes in deze situatie precies inhouden helpt om tot een afweging te kunnen komen. Het belangrijkste argument voor behandeling is dat dit zal leiden tot meer kwaliteit van het laatste stukje van haar leven en dat dit stukje ook wat langer zal duren. Belangrijkste argument voor respect voor autonomie is dat 'druk uitoefenen' een inbreuk is op haar wijze van omgaan met haar situatie, op haar recht daar zelf over te beslissen ook al vinden anderen die manier niet consistent. Wanneer het nadelig effect van de voorgestane behandeling onvoldoende helder of voorspelbaar is en tevens de grote wond op haar borst niet kan worden genezen of verkleind, wanneer ook andere symptomen van haar ziekte onvoldoende kunnen worden verlicht, lijkt het principe van autonomie in deze situatie de sterkste kaarten te hebben. De interne afweging die mevrouw Van Wendelen zelf maakt over het beoogde resultaat van de behandelingen (naar het ziekenhuis gaan om foto's te maken en daarna de bestraling) en of dat voor haar voldoende kwaliteit insluit om daar mee in te stemmen, is doorslaggevend. ${ }^{3}$

3 In situaties waarin het niet lukt om een afweging te maken die voor alle betrokkenen aanvaardbaar is, kan men zich beroepen op professionele verplichtingen. Dit door na te gaan welke actoren vanuit welke verschillende verantwoordelijkheden bij de situatie betrokken zijn. Wanneer het stappenplan geen uitsluitsel geeft over wat goed en wenselijk is kan op grond daarvan de mening van de arts in bepaalde situaties de doorslag geven (Van Willigenburg. 1998, p. 67). 
Het proces van afweging, dat beoogt de zwaarte van de morele argumenten aan te geven die in deze praktijksituatie van betekenis zijn, vereist argumentatie. De betrokkenen, de patiënt, de professionals, familie, kunnen redenen aangeven voor de opvattingen die in het geding zijn. Van Willigenburg (1998) onderscheidt publieke normen, professionele normen en relationele normen. Zorgvuldig moet worden nagegaan wat de verschillende normen en argumenten in dit specifieke geval te zeggen hebben. Daarbij is het van belang dat de persoon waarom het gaat, mevrouw Van Wendelen in dit geval, beslist of het goede (weldoen) van de voorgestelde behandeling voor haar voldoende oplevert. Belangrijk daarbij is dat zij alle benodigde informatie tot haar beschikking heeft, haar situatie kan overzien en de impact van de behandeling kan inschatten. In de situatie van mevrouw Van Wendelen, lijkt het op grond van de informatie uit de casus gerechtvaardigd te concluderen dat de arts er goed aan doet niet te lang aan te dringen op de beoogde behandeling. Respect voor autonomie lijkt het grootste gewicht in de schaal te leggen.

Het stappenplan wordt afgerond met de vierde stap, het omgaan met de uit deze conclusie voortvloeiende handelingsalternatieven en verantwoordelijkheden.

\subsubsection{De regelethiek in het spanningsveld tussen systeem en leefwereld, sterke en kwetsbare kanten van de regelethiek}

De uitgangspositie van dit hoofdstuk was na te gaan of er een ethiek is die voor de palliatieve zorg de spanning tussen systeem en leefwereld goed uitwerkt. De regelethiek draagt bij dat zij door haar gestructureerde benaderingswijze en duidelijke uitgangspunten houvast biedt in de dagelijkse praktijk van de zorgverlening en het mogelijk maakt methodisch om te gaan met ethische vragen en problemen. Voor regelmatig voorkomende of vergelijkbare situaties kunnen procedures worden afgesproken. Met de toegenomen aandacht voor de fundamentele waarde van respect voor autonomie als een van de verworvenheden van de moderne tijd draagt de regelethiek daarnaast bij aan emancipatie en gelijkwaardige verhoudingen.

De rationele benadering met de nadruk op rechten en plichten, regels en protocollen, draagt echter ook bij tot afstandelijke onpersoonlijke verhoudingen, waardoor de leefwerelddimensie van het werk in de zorgverlening minder kansen krijgt. Interpersoonlijke betrokkenheid, emoties en existentiële vragen maken geen deel uit van de ethische discussie (Widdershoven, 200ob). Het zijn vragen en ervaringen die concrete situaties altijd meebepalen, maar zij blijven vanuit deze optiek onderbelicht en moeilijk te verstaan of onder woor- 
den te brengen. Dit brengt spanning met zich mee voor de mensen in de praktijk.

Het terugbrengen van ethische problemen tot principes en protocollen draagt het gevaar in zich dat andere belangrijke elementen die in concrete situaties een rol spelen buiten spel blijven (Widdershoven, 1995). De praktijk laat zien dat wat goed en ook wat minder goed is veel gezichten heeft. Individuele situaties brengen nieuwe aspecten aan het licht: 'Differently situated people may face different moral problems or experience similar ones differently' (Walker, 1998, p.50). Algemene principes en regels spelen een belangrijke rol in het waarnemen van morele problemen. $\mathrm{Zij}$ zijn verbonden met waarden en normen, die de geschiedenis van mensen en de wereld waarin zij leven heeft voortgebracht en sturen niet alleen het waarnemen, maar ook het oordelen en de morele intuïties die zich in concrete situaties aan ons opdringen. De details en nuances die individuele situaties kleuren vragen echter in de meeste gevallen om flexibele toepassing van die regels. Regels zijn, aldus Nussbaum (1998), vuistregels, die bij elk concreet moreel oordeel opnieuw betekenis krijgen of zelfs geheel kunnen worden herzien. Nussbaum wijst in navolging van Aristoteles op het belang van ervaring. Zij zegt: 'De erkenning dat het goede vele dimensies kent, impliceert dat we hooguit een verzameling leefregels kunnen formuleren, waarbij de afwegingen tussen conflicterende regels nooit in het algemeen, maar per situatie moeten plaatsvinden' (p.r7). Zij introduceert het belang en de kracht van de liefde omdat liefde altijd contemplatie van het schone (het goede) inhoudt. Kwetsbaarheid en afhankelijkheid en andere, meer negatief geladen emoties, worden hiermee binnengehaald. Ook zij maken deel uit van de menselijke ervaring. Van Asperen (1993) sluit hierbij aan. Zij zegt: 'Wat de ethiek behoort te doen, behalve het formuleren van regels en principes, is de menselijke ervaring verwoorden op een manier die ons inzicht verdiept en ons oor voor situaties schoolt (p.74).' De inspanningen die wij verrichten om pijn, ziekte en dood uit te bannen, moeten geen doel op zich worden, dat uitgroeit tot de mythe van het onbegrensde zelf. $\mathrm{Zij}$ moeten deel blijven uitmaken van een gemeenschappelijke cultuur waarin mensen elkaar verstaan in het spreken over persoonlijke ervaringen en zinvragen zoals juist over pijn, ziekte en dood. Gemeenschappelijke zingeving helpt mensen de beperktheid en kwetsbaarheid van hun doen en laten beseffen, aldus Van Asperen.

Van Asperen en Nussbaum verwijzen impliciet naar de spanning en het tekort van een systeemwereld-benadering, waar systeemeisen, rationele regels en principes en daarmee verbonden taalgebruik, het primaat hebben. $\mathrm{Zij}$ pleiten in hun theoretische beschouwingen voor een op de praktijk gerichte ethiek, en stellen juist leefwereldervaringen centraal. Niet de regels en principes staan op 
de voorgrond, maar de mens in zijn pogingen om goed te leven. Ruimte voor emoties en de mogelijkheid tot ethische reflectie die aansluit bij de concrete ervaring zijn belangrijke voorwaarden om te komen tot een afweging in moeilijke situaties. Deze inzichten bieden zicht op een benadering van ethische vragen en problemen die wezenlijk anders is dan de regelethische. Voor de praktijk van de gezondheidszorg zijn voor een dergelijk alternatief aanzetten gedaan, beschreven in de zorgethiek.

\subsection{De zorgethiek}

De aanzet tot de ontwikkeling van de zorgethiek kwam van Gilligan (1982) in haar kritiek op het werk (over de ontwikkeling van het morele oordelen) van Kohlberg. Naast morele principes als rechtvaardigheid (Kohlberg), beschrijft zij principes van verbondenheid, van zorgzaamheid en verantwoordelijkheid (Van Osselen, 1989; Smits, 1997). Deze bredere opvatting van moraliteit is te herkennen in de zorgethiek, onder anderen door Tronto (1993) beschreven. Zij ontwerpt in haar boek een morele en politieke theorie, waarin zorg als belangrijkste betrekking tussen mensen en tussen mensen en hun omgeving, centraal staat. In haar benadering staan niet zo zeer de morele regels centraal, maar veel meer de onderlinge betrokkenheid en de daarbij behorende kwaliteiten van mensen om ethische problemen te herkennen en te weten hoe daarin te handelen. Waar de regelethische benadering is verbonden met het beeld van mensen als onafhankelijke, rationele wezens, gericht op het nastreven van zelfgekozen doelen, gaat de zorgethiek uit van een relationeel mensbeeld. Mensen zijn afhankelijk van elkaar, zij hebben elkaar nodig om doelen te verwezenlijken.

Zorg is volgens Tronto een complexe praktijk, waarin mensen over specifieke morele kwaliteiten moeten beschikken. Het vraagt van de betrokkenen niet alleen professionele kennis en vaardigheden om de zorg te kunnen verlenen, maar ook motivatie die in houding tot uitdrukking komt: een habit of mind' om te zorgen: 'To be a morally good person requires, among other things, that a person strives to meet the demands of caring that present themselves in his or her life' (Tronto, 1993, p.126). Het proces van zorgverlenen wordt door Tronto beschreven in vier fasen, die zowel theoretisch als praktisch van aard zijn: caring about, taking care of, care-giving en care-receiving. Deze vier elementen van zorg hangen met elkaar samen en zijn van elkaar afhankelijk. Zonder 'caring about', is er geen 'care-giving' of 'receiving'.

Caring about, zich bekommeren om, zich het lot aantrekken van, vraagt een houding van oplettendheid, van aandacht om de (zorg)noden van anderen te herkennen. Vanuit deze ethische optiek is het veronachtzamen van zorgbe- 
hoeften, het niet attent zijn op noodsignalen, immoreel gedrag. Nodig om deze oplettendheid te ontwikkelen is, volgens Tronto, de mogelijkheid en de bereidheid van mensen eigen doelen en ambities (tijdelijk) opzij te zetten om ruimte te maken en ontvankelijk te kunnen zijn voor de behoeften van anderen. Dat betekent niet dat men zichzelf helemaal moet wegcijferen: 'After all, in order to recognize that others have needs that are not being met, one needs to be in a position to recognize others; this would mean that one's own needs have been sufficiently met so that one is able to glance around and notice others' (p. I31). Met andere woorden, het gaat er niet alleen om jezelf opzij te kunnen zetten, er wordt een zekere rijpheid, levenservaring en levenskunst zoals hierboven beschreven verlangd, waarin naast kennis en kunde een begrip gegroeid is van de eigen vergankelijkheid en van de onmisbaarheid van de anderen.

Het tweede door Tronto genoemde element, 'taking care of', is verbonden met de ontwikkeling van een gevoel van verantwoordelijkheid. De verantwoordelijkheid van waaruit men zich verplicht weet actie te ondernemen, een proces in gang te zetten, de middelen ter beschikking te stellen waardoor de zorg kan worden georganiseerd: 'Throwing money at a problem does not adequately recognize all of the care that must accompany the translation of those resources into care-giving and care-receiving' (Tronto, I993, p.138).

Met 'care-giving' is competentie verbonden. Tronto vindt het belangrijk, dat ook de activiteit van de zorgverlening, de competentie daartoe, wordt gezien als morele dimensie van zorg. $\mathrm{Zij}$ maakt dat duidelijk door te stellen dat de verantwoordelijkheid niet stopt bij het herkennen van een zorgbehoefte en het ter beschikking stellen van de zorgverlening. Het resultaat is even belangrijk. Het beschikbaar stellen van zorgvoorzieningen als verpleeghuizen, hospices, ziekenhuizen en dergelijke zonder ook te zorgen voor voldoende en goed opgeleide zorgverleners voor de uitvoering van het werk, voldoet niet aan de eisen van een zorgethiek.

Tenslotte gaat het ook om 'care-receiving', een begrip dat vaak ten onrecht verbonden is met een idee dat diegenen die de zorg ondergaan passieve elementen zijn in het zorgproces. Care-receiving is verbonden met de morele kwaliteit van responsiveness, responsiviteit. Hier komt de actieve rol in zicht van degene die de zorg ontvangt. Ook de zorgontvanger draagt een verantwoordelijkheid, namelijk om zo adequaat mogelijk inzicht te geven in de eigen zorgbehoeften. Dit vraagt van zorgverleners een morele houding van bereidheid ontvankelijk te zijn voor het perspectief van de ontvanger van zorg. Binnen een zorgrelatie treedt naast automie de kwetsbaarheid en het bij anderen betrokken zijn van mensen aan het licht. Het morele concept van responsiveness impliceert een wederkerigheid tussen zorgontvanger en zorgverlener: de verantwoordelijkheid van de zorgontvanger zicht te houden op eigen zorgbehoeften en van de 
zorgverlener alert te blijven voor mogelijk misbruik van die kwetsbaarheid in deze situaties. Responsiveness vraagt van zorgverleners te begrijpen wat de behoeften zijn van zorgvragers, zonder dat zij er van uit gaan in staat te zijn zich geheel in hun standpunt te verplaatsen.

De zorgethiek biedt in de situatie van mevrouw Van Wendelen een nieuw perspectief, waarin de onderlinge betrokkenheid een belangrijke rol speelt en het zorgproces een zoeken inhoudt naar de meest leefbare situatie, in de wetenschap dat die altijd voorlopig is en dat een definitief antwoord niet bestaat (Widdershoven, 200ob).

Om haar situatie te interpreteren en mogelijkheden te zoeken hoe ermee om te gaan, wordt vanuit zorgethisch gezichtspunt geen stappenplan gevolgd. De zorg wordt vanuit dit perspectief gezien als een antwoord op de vraag van de ander (Widdershoven, 200ob). In het organiseren en verlenen van zorg gaat het erom steeds te luisteren naar de behoefte van degene om wie het gaat, waar de zorg en de aandacht naar uitgaat. Aandacht, verantwoordelijkheid, deskundigheid en responsiviteit binnen de sociale werkelijkheid die elke situatie uniek maakt, geven richting aan het zorgproces. Een proces dat steeds de inbreng van de ander, in dit geval mevrouw Van Wendelen, nodig heeft. Vanuit haar vragen en behoeften wordt het zorgproces in gang gezet en de nodige deskundigheid ingeschakeld.

Dat vraagt voortdurende afstemming tussen de zorgverleners onderling en tussen zorgverleners en patiënte. Responsiveness en het daarmee verbonden concept van wederkerigheid worden gezien als noodzakelijk elementen van het gehele zorgproces. In dit licht vraagt de bezorgdheid van de arts over de risico's die mevrouw loopt door af te zien van de door hem voorgestelde behandeling, een gelijkwaardige plaats in het gesprek over de inhoud van de te organiseren zorg. Zijn deskundigheid en ervaring brengen het inzicht mee dat de gevolgen van niet ingrijpen nieuwe en wellicht moeilijk behandelbare problemen kan opleveren in de nabije toekomst. Zorg als een gezamenlijke onderneming vraagt van alle betrokkenen de inbreng van inzichten en ervaringen. Het is daarbij echter volgens de zorgethiek niet voldoende na te gaan of mevrouw voldoende is geïnformeerd over de mogelijkheden die er zijn haar leven te verlengen, de kwaliteit ervan te verbeteren en over de mogelijke negatieve effecten van behandelen of van juist niet behandelen. Belangrijk daarnaast is in een gesprek met mevrouw en eventueel met haar kinderen en met andere zorgverleners, helder te krijgen wat het afzien van behandeling en het onafwendbare sterven voor haar betekenen. Inzicht in haar beleving van de situatie zoals deze zich aan haar voordoet helpt, om te begrijpen wat zij nodig heeft. Na de inzet van de pijnbehandeling heeft zij wellicht meer ruimte gekregen over het naderende levenseinde na te denken en haar situatie te accepteren of om haar eer- 
dere behoeften in een ander licht te zien en bij te stellen. De wisselende stemmingen van mevrouw kunnen het lastig maken voor zorgverleners een eenmaal ingezet beleid door te voeren. Toch blijft het erom gaan naar haar te luisteren en serieus te nemen wat haar behoefte is. Dit door steeds opnieuw met haar af te stemmen wat mogelijk is en wat goed is voor haar. Vanuit de zorgethiek is dit een doorgaand proces in veranderende situaties.

\subsubsection{Autonomie en kwetsbaarheid, positieve vrijheid}

Tronto's mensbeeld waarin kwetsbare afhankelijkheid en zelfredzame autonomie als gelijkwaardige en elkaar doordringende aspecten van het menselijk bestaan worden gezien, wordt gesteund door Manschot (1997). Volgens Manschot staat in de huidige inrichting van het leven, de zorg voor elkaar op gespannen voet met opvattingen over het zelfbeeld van de vrije autonome mens. Naast autonoom, is de mens ook een lichamelijk wezen. Kwetsbaarheid en eindigheid zijn deel van zijn bestaan. Het belang dat in de huidige samenleving wordt gehecht aan autonomie, zelfstandigheid en rationaliteit, leidt tot steeds individuelere leefpatronen, waarin geen rekening wordt gehouden met mensen die voor hun bestaan afhankelijk zijn van zorg voor anderen. Manschot bekritiseert de gangbare opvatting van autonomie in de gezondheidszorg, waar de mens wordt gezien als zelfredzaam wezen en men het principe van informed consent" en 'niet inmenging' huldigt. De zorg is erop gericht de mens 'zo zelfredzaam mogelijk' te laten zijn. Zijn afhankelijkheid moet zoveel mogelijk worden beperkt. Eindigheid wordt vanuit deze opvatting van autonomie verbonden met onvolkomenheid of gebrek (Manschot, 1997). In plaats daarvan pleit Manschot voor een benadering waarin de kenmerken van het menselijk bestaan juist geaccepteerd worden, namelijk dat mensen kwetsbare wezens zijn en sterfelijk en dat mensen niet alleen op zichzelf zijn gericht maar altijd ook op anderen zijn aangewezen. De ethische praktijk van de zorgverlening vraagt om kwaliteiten als generositeit, vriendschap, solidariteit, liefde, betrokkenheid bij anderen. In Manschots opvatting is autonomie een levenskunst, die ontspringt aan het besef van de eigen vergankelijkheid en van de onmisbaarheid van de anderen. Tegenover de opvatting van autonomie als negatieve vrijheid, zoals in de regelethiek, staat autonomie als positieve vrijheid, waarbij de betrok-

4 Informed consent, een in de gezondheidszorg gangbare term voor het (meestal door medici) verstrekken van informatie aan de patiēnt en/of zijn familie, op basis waarvan door de betreffende patiënt/of zijn vertegenwoordiger(s) zelfstandig een weloverwogen beslissing (over bijvoorbeeld wel of niet behandelen) genomen kan worden. 
kenheid van mensen bij elkaar meer op de voorgrond staat. Steun en eventueel ingrijpen van anderen betekent niet automatisch een inbreuk op deze autonomie (Tronto, 1993; Manschot, 1997; Widdershoven, 200ob).

In navolging van Socrates beschouwt Manschot erkenning van eindigheid als een voorwaarde van autonomie. Mensen die afhankelijk worden genoemd omdat zij op de zorg van anderen zijn aangewezen, kunnen in deze visie juist autonomer zijn dan anderen, omdat zij nadrukkelijker met de kwetsbaarheid van het leven zijn geconfronteerd. 'Onafhankelijk is de mens die zin kan geven aan de eindigheid en de grenzen van het bestaan weet te integreren in de eigen levensvoering. Afhankelijk is diegene die de grenzen van het lichamelijke miskent of negeert' Manschot (1997, p.rIo). Onafhankelijkheid is volgens Manschot het resultaat van inspanning, vorming, training en (levens)ervaring.

Mevrouw Van Alphen is sinds twee weken in het hospice, zij lijdt aan darm. kanker. Mevrouw is een jaar of 50 , is getrouwd, zij heeft geen kinderen.

De situatie is ernstig, er is sprake van een totale darmafsluiting. Patiēnte is erg zwak en moe. Ze ligt op een eenpersoonskamer. Gedurende de nacht heeft ze veel gebraakt, de inhoud van de darm die niet meer langs de normale weg het lichaam kan verlaten, komt eruit. 's Morgens ligt ze verzwakt en uitgeput in bed, ze vraagt of de arts langs wil komen.

Ze vraagt de arts om raad. 'Wat moet ze doen? De hele nacht is ze zo ziek geweest, nu heeft ze weer een honger gevoel. Zal ze iets eten?'

$\mathrm{Na}$ lichamelijk onderzoek legt de arts uit dat mevrouw zelf moet beslissen. Zij kan geen uitsluitsel geven: de darm is weliswaar afgesloten, maar hoe volledig. dat is niet met zekerheid te zeggen. Het kan zijn dat het voedsel waar ze trek in heeft een weg vindt door de darm. Het kan ook zijn dat het er van boven weer uitkomt. De kans acht de arts fifty-fifty.

Weer vraagt mevrouw: Wat moet ik doen? Waarop de arts geduldig hetzelfde antwoord geeft. Dit gesprek gaat zo een tijdje door. Ook de verpleegkundige is aanwezig en met veel geduld en toewijding wordt mevrouw duidelijk gemaakt dat zijzelf mag beslissen.

Zij besloot nog wat te wachten.

Wanneer de arts en de verpleegkundige de kamer hebben verlaten, verzucht mevrouw: "Je moet hier ook alles zelf beslissen!"

Uit het voorbeeld van mevrouw van Alphen komt een beeld van een praktijk naar voren, waarin door de zorgverleners aan autonomie een hoge waarde wordt toegekend. Men hanteert een autonomiebegrip, dat uitgaat van de vrije en zelfstandige mens, in staat om zelf te beslissen en eigen doelen na te streven. Zorgverleners gaan ervan uit dat autonomie niet alleen een wenselijk, 
maar vooral een noodzakelijk aspect is van het menszijn. Gezond of ziek, autonomie is een leidend principe, dat voor iedereen geldig is. Er wordt ruimschoots de tijd genomen om mevrouw van Alphen duidelijk te maken dat zijzelf moet beslissen. De wens van de patiënte tijdelijk deze vrijheid op te geven, omdat ze bang is voor de gevolgen van een verkeerde beslissing, of omdat ze moe is en pijn heeft, geen kracht en moed om het heft in eigen handen te houden, past niet in de opvattingen van deze zorgverleners. Tegelijk doen zij wat zij eigenlijk niet willen: voor haar beslissen. Mevrouw van Alphen voelt zich in de steek gelaten, ze wordt alleen gelaten met haar vragen. $\mathrm{Zij}$ moet uiteindelijk zelf beslissen wat ze gaat doen: haar honger stillen en wat eten, of er van afzien omdat ze bang is weer te gaan braken.

Of men hiermee werkelijk recht doet aan de autonomie van de patiënt, is in het licht van een bredere opvatting van autonomie de vraag. Manschots pleidooi voor een benadering waarin de kwetsbaarheid van mensen wordt geaccepteerd en waarin plaats zou moeten zijn voor de afhankelijkheid en het in sommige situaties op de zorg van anderen te zijn aangewezen, vindt in de hier beschreven praktijk geen weerklank.

\subsubsection{Dialoog als basis van de zorgethiek}

Ethisch theoretische stromingen leveren geen concrete oplossingen voor problemen in een individuele zorgpraktijk. Het bestuderen van deze theorieën, het eigen maken van de ideeën, biedt mogelijkheden om inzicht te krijgen, wegwijzers te vinden voor het denken en handelen. In de praktijk van de dagelijkse zorgverlening zijn mensen, die zijn betrokken bij 'goede' zorgverlening er steeds op aangewezen de vertaalslag te maken naar de individuele praktijken en de problemen waarmee men steeds opnieuw en steeds weer anders, wordt geconfronteerd.

Vanuit de regelethiek benadert men de (zorg)praktijk op een rationele wijze. Ethische problemen worden herleid tot in het geding zijnde principes. De vraag rijst wat volgens deze principes kan en geoorloofd is. De principes zijn bindend en sturen het beslissingsmodel. Een stappenplan biedt uitkomst in moeilijke situaties (Widdershoven, 200ob).

Het zorgethisch perspectief benadert de praktijk als een sociale werkelijkheid, waarin mensen bij elkaar betrokken zijn (Tronto, I993; Walker, r998). In de praktijk van de palliatieve zorg gaat het om zorgrelaties. In elk van die zorgrelaties speelt de achtergrond, de belevingswereld en de geschiedenis van de betreffende patiënt een belangrijke rol bij het interpreteren en verstaan van zorgbehoeften. Niet alleen door een rationele afweging van feitelijkheden, 
maar vooral ook door met elkaar in gesprek te gaan, proberen de partners in deze zorgrelatie tot consensus te komen over wat de behoeften en mogelijkheden zijn in specifieke situaties. Voor zorgverleners betekent dit aansluiting zoeken bij de leefwereld, het perspectief van de patiënt en het voor hem of haar transparant maken van ondoorzichtige processen van de zorgverlenerstraditie (Begeman, 1995). Dit is een hermeneutisch proces, waarin dialoog en wederkerigheid voorwaarden zijn voor het verstaan en begrijpen van zorgbehoeften en ethische problemen die zich kunnen voordoen.

Het gaat hier om de vraag welke behoeften er zijn voor de betrokkenen in de praktijk, welke zorg men in de verschillende en veranderende situaties nodig heeft. Door uitwisseling van perspectieven kan men tot overeenstemming en oplossing van het probleem te komen. Het dialogisch perspectief van de zorgethiek is niet als zodanig door Tronto uitgewerkt. Communicatie en overleg zijn echter geïntegreerd in het door haar beschreven zorgproces. Niet de zorgverlener bepaalt welke zorg, welk handelen of juist nalaten van handelen, bijdraagt aan de kwaliteit van het leven of van het stervensproces. De zorgvrager, de patiënt om wie het gaat, draagt een eigen verantwoordelijkheid. Zorgverlenen vanuit het perspectief van de zorgethiek, vraagt om zowel om een attent zijn, een verstaan en juist interpreteren van de signalen, als om reflectie en respons door degenen om wie het gaat. Zorg wordt gezien als een gezamenlijk proces met een dialogische structuur.

De regelethiek daarentegen, structureert het denk- en overlegproces in de richting van mogelijke oplossingen. Communicatie neemt ook hier een belangrijke plaats in, maar het is de zorgverlener, die het overzicht heeft, en de mogelijkheden om met het probleem om te gaan afweegt om het resultaat voor te leggen aan de patiënt. De dialoog staat minder op de voorgrond. De principes liggen vast, het zijn de mogelijkheden en tegelijk de grenzen om ethische vragen en problemen te herkennen en ermee om te gaan. De regels en criteria die in de regelethiek geldig zijn, zijn verankerd in het rechtssysteem van de Westerse samenleving, en geven daarmee ook de kaders, de ruimte aan waarbinnen het ethisch handelen plaatsvindt. Met andere woorden, regels en principes functioneren als basis voor formele procedures die oplossingen bieden voor de ethische vragen en problemen waarmee men zich ziet geconfronteerd.

\subsubsection{Hermeneutiek}

De dialogische benadering vindt zijn filosofische grondslag in de hermeneutiek. Hermeneutiek interpreteert menselijke uitingen. In Gadamers (1986) opvatting van hermeneutiek nemen wederkerigheid, relationele verbonden- 
heid, praktijk en evaring een centrale plaats in. Gadamer gaat ervan uit dat wie interpreteert, een relatie aangaat met de wereld, de persoon(en), die hij tracht te begrijpen. Hermeneutiek zal een belangrijker rol spelen naarmate in de samenleving pluralisme en relativisme toenemen. Juist nu door de toegenomen kennis op gebied van wetenschap en techniek elk inzicht in onszelf en in onze plaats in de samenleving discutabel, dus onzeker is geworden, krijgt het hermeneutisch begrijpen onvermijdelijk met vragen van zinverlies en zingeving te maken (Gadamer, In: Begeman, 1995). Opvattingen en redeneringen van zorgverleners, worden vanuit de hermeneutiek gezien als uitingen van ervaringen, die een onderdeel vormen van een historische context of praktijk (Gadamer, 1989; Widdershoven, 200ob). Ervaring is de bagage die mensen nodig hebben om te kunnen leren, om situaties of menselijke uitingen te herkennen of zich te verwonderen over situaties of uitingen die anders zijn. Ervaring betekent dat mensen over een bepaalde voorkennis beschikken.

Mevrouw Van Alphen stelde de vraag: "Wat moet ik doen?" Doordat de professionals alleen reageerden op de medische of zorgtechnische kant van de vraag en vasthielden aan de eigen opvatting van autonomie, werd de belangrijkste lading van de vraag, de eigenlijke behoefte waar mevrouw Van Alphen op dat moment mee zat, genegeerd. Namelijk de onderliggende existentiële vraag: "Zie hoe ik erbij lig, help me, ik ben bang, machteloos en wanhopig." Eigen existentiele vragen en ervaringen werden buiten schot gehouden, bewustzijn ervan had wellicht voor aansluiting kunnen zorgen en kunnen helpen bij begrijpen van haar diepere behoeften.

Zonder voorkennis is interpretatie, het vinden van betekenis niet mogelijk. Mensen zijn zich vaak maar gedeeltelijk van de eigen voorkennis bewust, maar iedereen beschikt er over. Alleen al door de gesitueerdheid in de eigen cultuur en in de eigen levensgeschiedenis. Levenservaring en ook professionele kennis, opgedaan door studie en praktijk, zijn onderdeel van deze menselijke bagage. De nadruk die Gadamer op openheid legt, is te vergelijken met Tronto's begrip van attentiveness. De zorgbehoeften van anderen te kunnen zien of herkennen, vereist een openheid, een attent zijn naar die anderen.

Mensen die menen dat hun bagage compleet is, die niet gemotiveerd zijn tot een dergelijke houding, ontnemen zich de mogelijkheid zich te verwonderen en te leren. $\mathrm{Zij}$ zullen zorgvragen die niet passen in hun perspectief en hun ervaring, niet opmerken of begrijpen. Gadamer gebruikt voor het proces van kennisgroei de termen 'werkingsgeschiedenis' en 'horizonversmelting'. Beide termen wijzen op de mogelijkheid van een steeds doorgaand proces (werkingsgeschiedenis) van verandering van kennis en inzicht. 
Herkenning van de behoefte van mevrouw Van Alphen zou het begin van een gesprek hebben betekend over hoe daaraan tegemoet te komen. Het bieden van menselijke nabijheid, het erkennen van haar angst zouden de horizon van zowel zorgverleners als van mevrouw Van Alphen hebben verbreed en haar het gevoel hebben gegeven gehoord te worden.

Als het de deelnemers aan dat proces lukt elkaar te begrijpen, verwerven zij daarmee een gedeeld inzicht, dat hun eerdere inzicht en opvattingen bijstelt. Met andere woorden, elke deelnemer begint aan dat proces vanuit de eigen kennis/ervaringsachtergrond (horizon), en als het gesprek lukt en daardoor nieuwe kennis ontstaat, treedt horizonversmelting op, een gezamenlijk nieuw inzicht in de situatie.

Deze hermeneutiek is niet voorbehouden aan zorgverleners en patiënten. Op alle terreinen van wetenschap, kunst en praktijk kunnen deze processen plaatsvinden. Zo biedt de hermeneutiek de onderzoeker ook mogelijkheden de opgedane kennis in verband te brengen met theoretische uitgangspunten, de voorkennis waaruit hij werkt en handelt, om niet alleen zijn eigen inzicht, maar mogelijk ook die theorieën die hij aanhangt, bij te stellen (Begeman 1995). De horizonversmelting, de overeenstemming als resultaat van de dialoog, houdt een verandering in voor alle partijen in dat gemeenschappelijke proces, 'waarin men niet blijft wie men was' (Gadamer, 1989; Widdershoven, 2000 b). Het dialogisch perspectief van de hermeneutiek wordt niet als zoda. nig door Giddens genoemd of uitgewerkt. Toch is dit met zijn begrip life-politics goed te verbinden. Life politics is een 'politics' van keuzen maken en van het nemen van beslissingen. Het gaat daarbij vooral om hoe deze keuzen en beslissingen de eigen identiteit beïnvloeden, om morele en existentiele vragen. De ontwikkeling van die identiteit is een reflexief proces. Om ervaringen, veranderende omstandigheden of problemen waarmee men wordt geconfronteerd te kunnen begrijpen en een plaats te geven in het eigen levensverhaal, moet men er een relatie mee aangaan. Het is een proces van vragen stellen, discussies aangaan en antwoorden vinden in interactie met de omgeving en de mensen die daarin een rol spelen.

\subsubsection{De zorgethiek in het spanningsveld tussen systeem en leefwereld, sterke en kwetsbare kanten van de zorgethiek}

De zorgethiek sluit meer dan de regelethiek aan bij de praktijk waar mensen op elkaar zijn aangewezen en waar ruimte is voor de persoonlijke beleving van waarden die in het geding zijn. Uitgangspunt van de zorg is de behoefte van de 
ander. De patiënt is een partner in het gesprek over wat wel of juist niet bijdraagt aan zijn of haar welbevinden. De praktijkgerichtheid biedt mogelijkheden voor de 'veelstemmigheid' van dat overleg.

Door het omarmen van relationele betrokkenheid en leefwereldervaringen, bestaat het risico van isolement en blijven leefwereld en systeem van elkaar verwijderd. De praktijk van de zorgverlening bevindt zich op het snijvlak van leefwereldervaringen en systeemeisen en het is de vraag of de zorgethiek met haar nadruk op relationele betrokkenheid, zorg en verantwoordelijkheid niet te veel de regels en grenzen, die onlosmakelijk en noodzakelijk ook met die praktijk als systeem zijn verbonden, verwaarloost.

Daarnaast gaat de zorgethiek uit van menselijke kwaliteiten die niet voor iedereen onproblematisch zijn in een cultuur die wordt gedragen door kennis, rationaliteit en juridische regels. Communicatie over datgene wat voor individuen grote waarde heeft, het nadenken en ter sprake brengen van morele problemen en existentiële vragen en zienswijzen, vraagt van mensen naast deskundigheid een groot invoelend vermogen en een behoorlijke bagage aan levenservaring en communicatieve mogelijkheden. Vanuit Giddens life-political perspectief kunnen hier parallellen getrokken worden. Ook hij wijst er op dat het stellen van morele en existentiële vragen, verbonden met de keuzen over hoe te leven', 'hoe zorgverlener te willen zijn', is verbonden met discussie en strijd (Giddens, 2001, p.214 ev.). Niet gemakkelijk dus. Het reflexieve process waarin identiteit tot ontwikkeling komt, 'the narrative of self-identity' is kwetsbaar en vindt plaats tegen de achtergrond van dagelijkse (leefwereld)ervaringen en de beperkingen van abstracte systemen. Voor de ontwikkeling van de eigen identiteit zijn intersubjectieve relaties belangrijk. Het eigen levensverhaal is verbonden met levensverhalen van anderen.

Begrippen als dialoog, consensus, leren en horizonversmelting verwijzen naar een ideale situatie waarin dat allemaal mogelijk is. Echter niet altijd zal het gesprek overeenstemming of 'horizonversmelting' opleveren. Dit kan verschillende oorzaken hebben. Soms is meer tijd nodig, soms ook liggen de ervaringen, de opvattingen van waaruit men vertrekt gewoon te ver uiteen. In de moderne samenleving met zijn expertsystemen en gelaagdheid van de bevolking naar leeftijd, opleidingsniveau, sociale klasse, en andere met macht en status verbonden krachten, is het niet verwonderlijk dat afhankelijk van de positie die men inneemt anders gedacht wordt over rationele oplossingen van morele problemen tussen mensen (Walker, 1998). Ongelijkwaardige verhoudingen tussen gesprekspartners kunnen het voeren van een dialoog in de weg staan. Ook kan men tegen fysieke grenzen aanlopen door beperkte beschikbaarheid van middelen, of wanneer voorzieningen tekortschieten. Een voorbeeld is het probleem van 'het verkeerde bed': 
In een hospice worden patiënten opgenomen in de laatste fase van hun leven. Soms is de opname tijdelijk, om pijnbestrijding in te stellen, een nieuwe balans te vinden en daarna weer naar huis te gaan. Vaak echter is het hospice een laatste verbliifplaats voor mensen waar zij zullen overlijden. Een van de gangbare opnamecriteria is dat er sprake is van een levensverwachting van niet meer dan drie maanden. Envaring heeft echter geleerd dat dit moeilijk van te voren precies is vast te stellen. Patiënten komen vaak in slechte lichamelijke conditie naar het hospice en kunnen daar, door de behandeling en verzorging, weer opknappen waardoor hun situatie zich stabiliseert. Het overlijden is minder acuut aan de orde. Als de opname daardoor een langere tijdsperiode in beslag gaat nemen en de zorg ook elders kan worden verleend, dan kan men aan de patiënt voorstellen terug naar huis te gaan, dan wel te worden overgeplaatst naar een verpleeghuis. Dat laatste betekent een vaak terugkerend probleem in het hospice, omdat de meeste mensen erg opzien tegen een nieuwe opname. Zij hadden verwacht in het hospice te blijven tot aan hun overlijden. Bovendien heeft het verpleeghuis bij veel mensen een negatief imago, is opname in een verpleeghuis een schrikbeeld voor zowel de patiënt als voor de familie.

In dit soort situaties is het wel mogelijk de dialoog aan te gaan, ook is het mogelijk dat overeenstemming wordt bereikt ten aanzien van de zorgvraag en ten aanzien van wat het meest wenselijk is in de gegeven situatie. Daarmee omgaan wordt bemoeilijkt door de systeemeisen, de rationele regels die verbonden zijn met de organisatie van het zorgsysteem en de instandhouding ervan. Het systeem staat hier los van de leefwereld, van de ervaringen en gevoelens van mensen die in deze situatie verzeild raken. Bedenkingen die zij hebben worden wel gehoord, een goed antwoord is nauwelijks mogelijk. De ruimte om die meest wenselijke oplossing te realiseren wordt beperkt door beschikbaarheid van schaarse middelen en door de opvattingen en de regelgeving binnen de gezondheidszorg. Deze beide, de beschikbaarheid van middelen, en de opvattingen ten aanzien van zorgbehoeften en zorgaanbod, van waaruit regels en procedures zijn vastgesteld, bepalen voor een groot deel het beleid.

De in de praktijk aanwezige randvoorwaarden, maken een werkelijk effectieve zorgethische benadering van die praktijk problematisch. De regels van de organisatie en de binnen het gehele gezondheidszorgsysteem geldende afspraken en procedures zetten voor een deel de relationele en op communicatieve verhoudingen gebaseerde zorgethiek buiten spel. Een regelethische benadering sluit hierbij beter aan.

Habermas' kritiek op de hermeneutiek van Gadamer is voor een deel hierop gebaseerd (Van Osselen 1989; Begeman, 1995). Gadamer ziet het gesitueerd 
zijn in een praktijk, in een traditie, als noodzakelijke voorwaarde om het gesprek aan te kunnen gaan. Waar bij hem het vooroordeel, gebaseerd op kennis, ervaring en traditie, dient als startpunt om vragen te stellen aan de praktijk (Widdershoven, 2000b), stelt Habermas dat diezelfde praktijk zich in veel situaties zodanig heeft verzelfstandigd, dat zij geen vragen, geen vrije communicatie of dialoog toelaat. Hij waarschuwt voor een 'schijnconsensus' (Begeman, 1995) waar overeenstemming plaatsvindt op basis van procedurele regels. Waar moeilijke ervaringen van mensen waarvoor zij hulp zoeken, worden vertaald in technische problemen en de context van de leefwereld buiten beschouwing blijft. Dat is misschien ook wat mevrouw Van Alphen overkwam. De vraag die zij uitte was verpakt in woorden van het systeem, een 'veilige' code die iedereen verstaat: Wat moet ik doen? Eten of niet eten? Professionele uitleg moet haar de informatie geven om zelf een beslissing te nemen. Daar is men het over eens. Ze blijft echter eenzaam achter met haar ervaringen van die nacht die haar hebben uitgeput en geconfronteerd met existentiële vragen, met angst en eenzaamheid.

\subsection{Ethiek en palliatieve zorg op het snijvlak van systeem en leefwereld}

De palliatieve zorg die zich losmaakte uit het gezondheidszorgsysteem om een praktijk te realiseren waarin niet de regels en het regelen centraal staan, maar het meer gaat om de interpersoonlijke relaties van betrokkenheid en zorg, balanceert op het snijvlak van systeem en leefwereld. Om de eigenheid te bewaren is een ethiek nodig die de basale ideeën van de palliatieve zorg in de praktijk levend houdt en blijft voeden. In die praktijk heeft de palliatieve zorg te maken met regels en eisen van het (gezondheidszorg)systeem waarbij ze aansluiting moet zoeken om haar voortbestaan veilig te stellen. Twee potentiële kandidaten voor een ethiek van de palliatieve zorg zijn de regelethiek en de zorgethiek. De regelethiek biedt regels en principes als houvast om ethische problemen te herkennen en om na te gaan hoe te handelen. Het is een rationele benadering die aansluit op de systeemwereld. De zorgethiek is verbonden met een grondhouding van relationele betrokkenheid en zorg en is meer verbonden met de context van de leefwereld. Zorgethiek lijkt beter aan te sluiten bij het begrip life-politics, de ontstaansgeschiedenis en uitgangspunten van de palliatieve zorg, maar dreigt zich te isoleren van het systeem waardoor de spanning tussen systeem en leefwereld intact blijft.

De regelethiek richt zich op mensen in moeilijke en ellendige situaties. Het is ook een ethiek die bijdraagt aan emancipatie. Tegelijk is de regelethiek deel 
geworden van een systeem dat de ervaringen, de emoties en existentiële vragen, de levensgeschiedenis en hoe die doorwerkt in de beleving van mensen, buiten de rationele discussie houdt over wat goede zorg en wat kwaliteit van leven is, of wat wenselijk is in specifieke situaties voor individuele patiënten. Waar de regelethiek teveel het systeem wordt ingetrokken, gebeurt het tegenovergestelde met de zorgethiek die zich teveel lijkt terug te trekken in de leefwereld waardoor zij, praktijkgericht als ze is, toch daarvan geïsoleerd dreigt te raken. Tronto houdt een pleidooi voor een (zorg)ethiek, die deel uitmaakt van een politiek bewustzijn. Haar pleidooi wordt onderschreven door anderen zoals Manschot (1997) en zijn opvatting over autonomie waarin naast zelfredzaamheid een belangrijke plaats is ingeruimd voor kwetsbaarheid en eindigheid en het bij anderen betrokken zijn. Waar bij Tronto het concept zorg centraal staat in het bij elkaar betrokken zijn, wordt dit concept door Manschot verbonden met het vocabulaire van de vriendschap. 'Vriendschappelijke zorg is niet gericht op rechtstreekse leniging van behoeften. Zij richt zich op de bevordering van de existentiële autonomie van de ander' (Manschot, 1997, p.II4 e.v.). Verkerk (2000) en Walker (1998) gaan uit van een (zorg)organisatie als praktijk van verantwoordelijkheid, waarin deelnemers gezamenlijk handelen en betrokken zijn bij elkaar. 'Een zorgpraktijk is niet alleen een antwoord op kwetsbaarheid, maar brengt zelf op haar beurt kwetsbaarheid voort' (Verkerk, 2000, p. II9). Een zorginstelling als verantwoordelijkheidspraktijk organiseert de zorg op een wijze die ruimte biedt voor de ethische dimensies van het werk waardoor ethiek een geïntegreerd deel uitmaakt van kwaliteit en beleid van de instelling. Van Asperen (1993) vergelijkt het beoefenen van de regelethiek met expertgedrag van een grammaticus en zegt: 'Hoewel het onder woorden brengen van niet goed gearticuleerde regels een rol speelt in de ethiek, denk ik dat het slechts een deel kan zijn van een interessante reflexieve praktijk' (p.74). Naast kennis en inzicht is de menselijke ervaring belangrijk. Het brandpunt van ethiek, aldus Van Asperen, is niet de vraag wat de juiste handeling is, maar de vraag wat voor soort mensen we moeten zijn en wat voor soort leven we moeten leiden. Zij pleit voor de mogelijkheid de ethische theorie die zich richt op rationele verheldering van morele argumenten te verbinden met een theorie die de menselijke ervaring aan het woord laat.

\subsection{Samenvatting}

Palliatieve zorg is ontstaan en tot ontwikkeling gekomen uit onvrede met het systeem waarbinnen de zorg voor stervenden beschikbaar was. Die start en ontwikkeling vond plaats buiten het gevestigde systeem van de gezondheids- 
zorg in Nederland en werd gedragen door particulier initiatief. Tegelijk blijft zij voor haar (voort)bestaan en beschikbaarheid afhankelijk van dat voorzieningensysteem en zoekt daar dan ook aansluiting bij. Een proces dat inmiddels zowel vanuit de overheid als vanuit de verschillende palliatieve zorgorganisaties wordt gestuurd en in een afrondende fase verkeert. Om te voorkomen dat, onder de druk van systeemeisen de eigenheid van de palliatieve zorg onder druk komt te staan en verloren gaat, is het ontwikkelen van een eigen ethiek belangrijk. Een ethiek die de spanning tussen systeemeisen en de leefwereldcontext goed uitwerkt en de uitgangspunten van de palliatieve zorg levend houdt. Hiertoe werden twee ethisch theoretische stromingen voor het voetlicht gebracht, de regelethiek en de zorgethiek.

De regelethiek benadert de praktijk vanuit algemeen geldende principes. In ethisch moeilijke situaties moet worden nagegaan welke principes in het geding zijn, om van daaruit tot een oplossing te komen. Vanuit de regelethiek staat de dialoog minder op de voorgrond. Soms ligt de regie meer bij de patiënt, soms bij de arts. De patiënt beslist weliswaar zelf, maar op basis van de informatie die de arts cq. zorgverlener verstrekt.

De zorgethiek ziet de praktijk van zorgverlenen als een proces met een dialogische structuur. Zorgverlener en patiënt staan in een relatie met elkaar, zijn op elkaar aangewezen om tot gezamenlijke interpretatie van de situatie te komen en oplossingen te vinden. Het in de regelethiek belangrijke concept van autonomie wordt vanuit de zorgethiek anders ingevuld. Niet alleen onafhankelijkheid en zelfbepaling, ook kwetsbaarheid en eindigheid maken een geïntegreerd deel uit van het menselijk bestaan. Autonomie betekent ook inhoud en betekenis kunnen geven aan het eigen bestaan. Mensen zijn in hun autonomie bij elkaar betrokken, steun en eventueel ingrijpen van anderen betekent niet automatisch een inbreuk op deze autonomie (Tronto, 1993; Manschot, 1997; Widdershoven, 200ob).

$\mathrm{Bij}$ het uiteenzetten van de beide ethische stromingen ging het om de vraag of er een ethiek is die de spanning tussen systeem en leefwereld goed uitwerkt en draaglijk maakt zodat men er praktisch mee kan omgaan. De regelethiek heeft met de nadruk op autonomie en rechtvaardigheid bijgedragen aan emancipatie en biedt met haar uitgangspunten houvast in moeilijke situaties. Door de nadruk op individuele rechten en plichten, rationalisering en juridisering, echter op een wijze die heel dicht ligt bij het systeemdenken. De zorgethiek kijkt niet zo zeer naar regels maar meer naar de behoeften van het individu, waarbij het niet alleen gaat om rationele maar ook om emotionele en existentiële dimensies. Zorgethiek staat daarmee dichter bij life-politics en de basale waarden van de palliatieve zorg, echter op een zodanige manier dat ze te veel de leefwereld wordt ingetrokken en zich dreigt te isoleren van het systeem. 
De zorgethiek noch de regelethiek lijken ieder op zich voldoende bij te dragen om de spanning tussen leefwereldervaringen en systeemeisen te overbruggen en de palliatieve zorg daarmee een fundament te verschaffen om haar eigenheid te bewaren op dat snijvlak van eisen, behoeften en verantwoordelijkheden waarin de praktijk van deze zorg zich afspeelt. Tronto pleit voor een ethiek die deel uitmaakt van politieke theorie en politiek bewustzijn. Haar theorie van zorg is verbonden met het uitgangspunt dat de mens naast een autonoom ook een kwetsbaar en afhankelijk wezen is. De scheiding tusen publiek en privé en de nadruk op het belang van algemene (regelethische)pricipes draagt bij tot veronachtzaming van leefwereldervaringen en behoeften, waarden die in de dagelijkse zorgpraktijk om aandacht vragen (Tronto, 1993). Een ethiek, die rationele verheldering van morele argumenten verbindt met menselijke ervaringen waarin emoties en existentiële vragen een rol spelen en waarin het concept van autonomie breed wordt opgevat, is een suggestie die nog veel vragen oproept.

Belangrijke voorwaarde om ethiek in de praktijk vorm te geven, is communicatie. Een concept dat in het volgend hoofdstuk verder wordt uitgewerkt. 


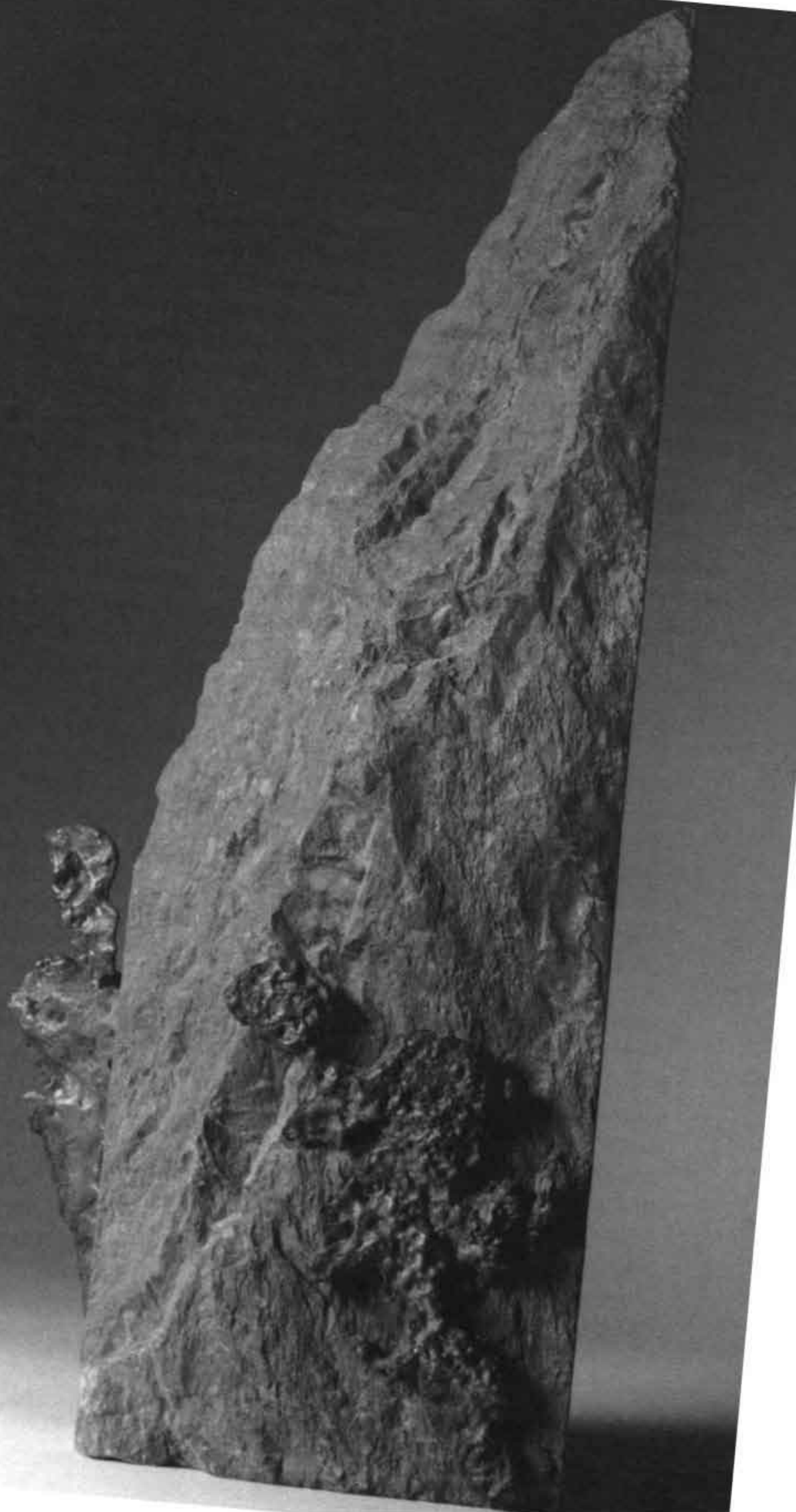




\section{Beperking}

Er is nog slechts een tijd van voor en nadat het gebeurde dat door de last van alles wat ik zag de aarde scheurde, steen voor steen.

En in de kantelende wanden zoeken handen sporen van verstoorde beelden, wat glad en gaaf was is verbrokkeld, steen na steen.

Tastend blijf ik aan het werk, omarm de muren, elke steen, breek mezelf door alles heen.

Mocht de wereld ooit vergaan, ik blijf voor jou

in beeld. 



\section{Ethiek in de praktijk: Communicatie in het spanningsveld tussen systeem en leefwereld}

Crito asks Socrates: "Don't you have a duty to save your life if you can?' Socrates: "The point, my dear Crito, is not simply to live, but to live well" (Moody, 1992).

\subsection{Inleiding}

De spanning tussen leefwereldervaringen en behoeften en systeemeisen zet het herkennen van en het spreken over morele en existentiële ervaringen onder druk. Daarom moet worden gezocht naar voorwaarden en mogelijkheden om ethiek in de praktijk vorm te geven op een wijze die ruimte biedt aan de ervaringen, behoeften en achtergronden van mensen in moeilijke situaties en die oog heeft voor de regels en normen van de (systeem)context waarbinnen die situaties plaatsvinden. Om te begrijpen waar het om gaat, wat die ervaringen en behoeften zijn en wat de betekenis en reikwijdte is van de systeemeisen, is communicatie vereist. Het omgaan met de grenzen van het menselijk bestaan en met de beperkingen van het spreken daarover, roept emoties en existentiële vragen op voor patiënt en familie, maar ook voor zorgverleners. De rol van communicatie is echter vaak beperkt. Niet alleen kent het verbaal onder woorden brengen van emoties, gevoelens, ervaringen, grenzen, soms is in het geheel geen communicatie met de patiënt meer mogelijk.

In dit hoofdstuk gaat het over de rol van communicatie. Waarom communicatie belangrijk is en waarom soms ook moeilijk. Het gaat over de functie van communicatie in de praktijk van zorgverlenen en de vraag hoe die communicatie te organiseren zodat de normatieve uitgangspunten van de zorg levend blijven. Voor de praktijk van palliatieve zorgverlening zijn communicatie en ethiek belangrijk. Ethiek in de praktijk vraagt om ruimte voor het organiseren van structurele vormen van communicatie en reflectie. Het creëren van randvoorwaarden voor een klimaat waar open communicatie en terugkerend overleg mogelijk is, is een belangrijke taak van organisaties. Ingegaan wordt op de vraag hoe ethiek zich in de praktijk zou kunnen ontplooien en ontwikkelen. Wat daarvoor nodig is en wat er moeilijk aan is. Niet alleen op het microniveau van zorgverleners en patiënt waar leefwereldervaringen een grote plaats inne- 
men en mensen geconfronteerd worden met emoties en existentiële vragen, maar ook op het mesoniveau van het management en het macroniveau van regelgeving en overheid, waar juist de systeemwerking explicieter op de voorgrond staat. De spanning tussen systeemeisen en leefwereldervaringen en behoeften, is een thema dat de drie theoretische hoofdstukken met elkaar verbindt.

\subsection{Communicatie in de praktijk}

De waarneming en interpretatie van problemen en behoeften en het omgaan met moeilijke situaties wordt meer dan door rationele regels, gestuurd door eerdere ervaringen, de betekenis die die ervaringen hebben gekregen in het eigen leven en het gedeeld begrip dat zij opleverden. Het omgaan met en verstaan van de ethische dimensies van de praktijk vereist communicatie en reflectie: 'To know what general norms or values mean in situations now requires appreciating how these have been applied and interpreted before, within individual and social histories. Narrative construction allow us to take thought backwards in these ways, and then forward to explore the costs and consequences of moral choices for individuals and between them' (Walker, 1998, p. 69).

De behoeften van mensen die het sterven onder ogen zien verschillen niet zoveel van die van mensen die gezond zijn. leder mens verlangt naar liefde, genegenheid, veiligheid, waardigheid en geborgenheid. Het zijn niet deze basisbehoeften die verschillen tussen mensen met een langer of korter levensperspectief, maar de omstandigheden. Bij stervenden worden veel van deze behoeften vaak genegeerd, of krijgen minder prioriteit (Van Orshoven, 1996 , p. 185). De zorgverlening voor patiënten in de laatste levensfase houdt een confrontatie in met meer dan alleen lichamelijk lijden. Het leven van terminale patiënten staat in het licht van de eindigheid, de betekenis daarvan dringt zich op aan alle dimensies van het bestaan en uit zich in pijn soms of in gebaren, in aanvaarding en ook in onrust, in het stellen van vragen en in het vertellen van (levens)verhalen. Het onder woorden brengen van wat werkelijk benauwt en mensen bezighoudt is voor velen van hen moeilijk, waardoor men is geneigd taal of symbolen te gebruiken, waarvan men aanneemt dat deze in ieder geval gehoord en begrepen zullen worden en waar 'iets aan gedaan kan worden'. Patiënten proberen aandacht te vragen voor dieper liggende emoties of problemen, in de taal die zij beschikbaar hebben.

Veel communicatie is non-verbaal. Dat betekent dat zorgverleners mede zijn aangewezen op het verstaan van betekenisvolle gebaren, of symbolisch taalge- 
bruik. Keirse (1996) spreekt van verschillende talen waarin de patiënt communiceert: het gewone spreken, niet-verbale symbooltaal en verbale symbooltaal. Met beelden en symbolen tast de patiënt en/of zijn familie de luisterbereidheid van anderen af. Existentiële vragen en onzekerheden zijn vaak moeilijk onder woorden te brengen. Veel mensen, die het sterven onder ogen moeten zien, zijn bang. De angst is vaak moeilijk te specificeren. Sommigen zijn bang om te stikken of om pijn lijden. Er is angst voor het onbekende, voor verlies van controle, of voor wat er na het sterven gebeurt. Angst heeft invloed op de kwaliteit van het leven, ook pijnbeleving kan er door beïnvloed worden (Van Orshoven, 1996, De Nijs, 2000). Typisch voor veel patiënten is volgens Zylicz (1998), dat deze negatieve angstige gevoelens verbonden zijn met eerdere ervaringen, met sterfgevallen in de familie, of verhalen van anderen. 'Men fear death as children fear to go in the dark and as that natural fear in children is increased with tales, so is the other' (Spiers, 1997).

Sommige angsten zijn onrealistisch, zoals de angst levend te worden begraven. Over deze angsten en ervaringen is vaak lang niet gesproken, het zijn pijnlijke plekken geworden, weggestopt omdat er in het dagelijks leven vaak weinig ruimte is om stil te staan bij vragen over sterven en angst. De taal ontbreekt daarvoor ook vaak omdat mensen deze ervaringen niet of te weinig met anderen hebben kunnen delen. Dit mede als gevolg van het rationaliseringsproces en het uit elkaar groeien van de systeem en leefwereld waarin mensen functioneren en samenleven (Habermas, I98I; Giddens, 200I). Geconfronteerd met het eigen naderend levenseinde komen de vroegere ervaringen vaak weer in alle hevigheid naar voren zonder dat men daar direct woorden voor vindt. Deze ongedifferentieerde angsten en onzekerheden komen dan naar buiten in moeilijk behandelbare pijnklachten of in andere lichamelijke symptomen. Luisteren naar het levensverhaal van deze mensen blijkt in die gevallen vaak meer op te leveren dan pijnmedicatie, en draagt bij aan een klimaat waarin mensen zich veilig en begrepen voelen.

Communicatie als centraal thema in de zorgverlening en in de palliatieve zorg misschien wel bij uitstek, vraagt van zorgverleners communicatieve vaardigheden, niet alleen om te luisteren en te spreken, maar vooral om de verschillende manieren waarop mensen zich uiten te herkennen, deze te verstaan en te kunnen interpreteren, de inhoud er van te begrijpen. Oog en oor hebben voor de niet altijd expliciet genoemde behoeften van de ander, vraagt om een attent zijn, om openheid en ruimte voor de behoeften en nood van anderen, samen met een groot inlevingsvermogen.

Een belangrijke voorwaarde voor een klimaat waarin aandacht is voor kwaliteit van communicatie, waar mensen zich vrij kunnen uiten en naar elkaar luisteren, is het aspect van veiligheid. Veiligheid is een belangrijk thema in de pal- 
liatieve zorg, zowel voor de patiënten als voor de zorgverleners. Niet alleen voor patiënten en familie is die veiligheid een belangrijke voorwaarde voor de kwaliteit van het bestaan. Ook zorgverleners hebben een werkklimaat nodig waarin zij zich veilig weten (Kunneman, 1998). Waar maatschappij, overheid en zorgorganisaties een goede en veilige plek willen bieden aan patiënten en hun naasten, geconfronteerd met het levenseinde, moet die kwaliteit ook gewaarborgd zijn voor de zorgverleners. Een veiligheid die, met andere woorden, is ingebed in de traditie, in de cultuur van de organisatie en in de verbanden waarin mensen met elkaar samenleven. Het vraagt om organisaties waar zorgverleners, professionals en vrijwilligers, zich gezien en serieus genomen voelen, waar hun eventuele ideeën en initiatieven verwelkomd en niet ontmoedigd worden (Kunneman, 1998, p. 124).

Niet alleen de kennis en vaardigheden van zorgverleners zijn belangrijk, het gaat net zozeer om kwaliteiten van medemenselijkheid, van visie-ontwikkeling en inspiratie, integriteit en betrouwbaarheid. De aard van het werk brengt met zich mee, dat zorgverleners regelmatig worden geconfronteerd met problemen van patiënten en de existentiële vragen waar zij vaak geen antwoord op vinden. Verzorgenden moeten hiermee zorgvuldig omgaan. Dit zal een beroep doen op hun emotionele betrokkenheid. Deze directe confrontatie met menselijk lijden is een van de zwaarste aspecten van verplegen. Emoties van anderen hebben een resonerende werking op eigen emoties; het zien van emoties van anderen roept eigen emoties wakker (The, I997b, p. 23). Kunneman (1998) gebruikt hier de term 'normatieve professionaliteit' als het vermogen professionele en technische competenties te integreren in een persoonlijk doorleefde en normatief verantwoorde manier van omgaan met deze vragen. Hiervoor is het belangrijk dat zorgverleners kunnen putten uit eigen existentiële hulpbronnen en van daaruit verbanden kunnen leggen met het werk dat ze doen en met de wijdere maatschappelijke context. Deze normatieve betrokkenheid, deze intergratie van kennis, vaardigheden en houdingen is slechts mogelijk wanneer binnen de organisatie hiervoor de noodzakelijke randvoorwaarden worden ontwikkeld. In het bijzonder gaat het daarbij om een klimaat waar open communicatie mogelijk is, zowel met patiënten als tussen zorgverleners onderling. Daarnaast is het nodig dat er ruimte en tijd beschikbaar is om te discussiëren over de spanningen tussen professionele eisen vanuit de verschillende disciplines en de individuele ervaringen en verwachtingen of, met andere woorden, om de spanning tussen de systeemeisen en leefwereld bespreekbaar te maken en te verminderen. Het zijn mogelijkheidsvoorwaarden voor gemeenschappelijke leerprocessen met het oog op kwaliteit van zorg.

Hoewel van organisaties gevraagd wordt deze randvoorwaarden te realiseren. is het van belang dat de communicatieve processen niet van bovenaf worden 
opgelegd, maar op basis van gelijkwaardigheid plaatsvinden. Geen implementatie van opvattingen, maar ruimte voor de ontwikkeling ervan vanuit de basis, de praktijk waar de zorg plaatsvindt. Het streven naar kwaliteit van zorg is zo onderdeel van een communicatief proces, dat steeds doorgaat. Kunneman introduceert hier de term 'horizontale kwaliteitszorg', verbonden met 'horizontale communicatie': communiceren op basis van gelijkwaardigheid, betrokkenheid en openheid voor de mogelijke waarde van de inbreng van de ander. Zorgethische beleidsontwikkeling, zo zou je ook het kunnen noemen. Verkerk (2000, p.II7) sluit hierbij aan, zij zet een moreel beraad op de agenda. 'Goede zorg', zegt zij, 'is het resultaat van een proces van beraadslaging en onderhandeling tussen de verschillende betrokkenen die op hun beurt onderscheiden (machts-)posities innemen in de organisaties of praktijken'. Een regelmatig terugkerend moreel beraad biedt zorgverleners de mogelijkheid hun motieven en oriëntaties op 'goede zorg' te expliciteren en daarover met elkaar in gesprek te gaan. Een van de belangrijkste criteria van zo'n beraad is dat ieders stem gehoord en erkend wordt, aldus Verkerk. Zorginstellingen moeten worden gezien als verantwoordelijkheidspraktijken, waarin de kwetsbaarheid van individuen in verschillende gedaanten aan het licht treedt. Een zorgpraktijk is niet alleen een antwoord op kwetsbaarheid, zij brengt op haar beurt kwetsbaarheid voort. Hiërarchische verhoudingen, botsende verantwoordelijkheden, het belang van kosteneffectiviteit en efficiency kunnen komen te staan tegenover betrokkenheid en aandacht waaruit zorgverleners willen werken. Binnen organisaties dient hier aandacht voor te zijn.

\subsection{Communicatie als (hermeneutisch) leerproces}

Hermeneutiek betekent lerend in het leven staan. Dit sluit aan bij de moderne tijd, waarin volgens Giddens, in navolging van Habermas, kennisclaims altijd tijdelijk van aard zijn en morele en religieuze opvattingen niet langer onbetwijfelbaar, maar bekritiseerbaar geworden zijn.

Communicatie, als medium en brug tussen theorie en praktijk, tussen ideaal en werkelijkheid van de palliatieve zorgverlening, houdt een opeenvolging van leerprocessen in. Om te kunnen begrijpen hoe iemand anders, een patiënt, een collega zorgverlener de (zijn of haar) werkelijkheid benadert, welke waarden en normen daarbij belangrijk zijn, of welke concepten van kwaliteit, autonomie, moraliteit daarin een rol spelen, moet men de eigen opvattingen en ideeën in het spel brengen. Dit inzicht is ontleend aan de hermeneutiek van Gadamer. 'Nicht so sehr unsere Urteile als unsere Vorurteile machen unser Sein aus'(Gadamer, 1986, bII, p.224). Gadamers Vorurteile, verwijzen naar de 
historiciteit van ons bestaan, de achtergrond waaruit men denkt en handelt. Die eigen achtergrond, de kennis en ervaringen die bepalend zijn voor het denken en handelen, is de mogelijkheidsvoorwaarde om vreemde of afwijkende meningen of ervaringen tegemoet te treden. Willen afwijkende ervaringen werkzaam zijn, dan dienen deze niet voort te komen uit een gevoel van superioriteit, maar uit verwondering over datgene wat men aantreft (Widdershoven, 2ooob, p. 8r). De verwondering over het vreemde leidt tot de volgende stap, het gesprek, om in het licht van de eigen opvattingen die van de ander te begrijpen, er van leren. Het is een proces dat nieuwe kennis en inzichten kan opleveren, het is ook een proces dat, met elke nieuwe ervaring, steeds doorgaat.

In dit licht is het voor zorgverleners van belang, dat zij zich bewust zijn van zowel persoonlijke opvattingen, door het eigen socialisatieproces geinternaliseerd, als ook van de eisen van de beroepsgroep en de theoretische uitgangspunten van de palliatieve zorgpraktijk. Vanuit deze open houding wordt niet alleen de patiënt benaderd, maar ook de hele omgeving. De mensen waarmee wordt samengewerkt, collegae en andere bij de zorg betrokkenen, het management van de organisatie, zij vormen gezamenlijk een communicatieve bron waaruit men moet kunnen putten om de uitgangspunten en opvattingen, de standaard die men persoonlijk en gezamenlijk heeft opgesteld te beheren en zo nodig bij te stellen, steeds als het ware te verversen (Kunneman, 1996). Ook voor de zorgvrager, de patiënt en zijn omgeving, gaat dit op. Hij is het centrum van de zorg, gericht op de kwaliteit van zijn leven. Alleen in een dialogisch proces, waarin ervaringen, verlangens, angst en hoop kunnen worden 'uitgesproken', een communicatief proces waarin opvattingen kunnen worden gedeeld, maar waar ook verschillen van inzicht en waardering mogelijk zijn, krijgt het streven naar kwaliteit gestalte in beschikbare zorgverlening.

Hermeneutiek kan bijdragen aan de kwaliteit van communicatie in de palliatieve zorgpraktijk. Tegelijk laat de praktijk zien dat het model soms te mooi is om waar te (kunnen) zijn. Habermas' ideologiekritiek heeft dat naar voren gebracht, de spanning tussen systeem en leefwereld is er een voorbeeld van (in hoofdstuk 2 uiteengezet). Uitgangspunten van de hermeneutiek als openheid, dialoog, uitwisselen van ervaringen, het met elkaar spreken over kwaliteit, over wenselijkheid, over hoop en verlangens, houden mogelijkheden in de spanning tussen systeem en leefwereld te verminderen. Zij verlangen een praktijk die deze uitgangspunten ruimte geeft, uitdraagt en onderhoudt en zij verlangen van individuen een houding en vaardigheden die daarmee in overeenstemming zijn. lets wat in de moderne tijd voor veel mensen juist moeilijk is geworden. 


\subsection{Communicatie op het snijulak van systeem en leefwereld}

Hoewel communicatie een centrale rol speelt in de zorgverlening, kan tegelijk lang niet alles wat bij patiënten of bij de zorgverleners vragen oproept, ter sprake worden gebracht. Een spanning die soms meer, soms minder voelbaar, steeds aanwezig is als spanning tussen systeem en leefwereld. Het formuleren van vragen over de zin, de betekenis van leven en lijden, het ter sprake brengen van wat mensen ten diepste bezig houdt, juist bij het afscheid van het leven, is moeilijk. Het kan moeilijk zijn de juiste woorden te vinden en vaak is nog moeilijker deze te verstaan en ermee om te gaan. Verkerk wijst op de sociale context waarbinnen de zorgverlening zich afspeelt en ethische problemen zich kunnen voordoen. $\mathrm{Zij}$ zegt: 'morele kwesties komen niet uit de lucht vallen maar zijn altijd van iemand die op zijn of haar beurt een bepaalde plek inneemt in de sociale werkelijkheid, die vaak door machtsverhoudingen is gekleurd' (Verkerk, 2000, p. II5). Zij wijst niet alleen op de inbedding van ethiek in de praktijk maar ook op de verschillende perspectieven waarmee mensen naar die praktijk en naar ethische kwesties in die praktijk kijken. Morele opvattingen zijn verbonden met de identiteit van mensen en daardoor vaak emotioneel geladen, aldus Verkerk. Dit staat op gespannen voet met de rationaliteit van het systeem. Morele kwesties verdragen zich niet goed met associaties van afstandelijkheid en maakbaarheid, die daaraan eigen zijn.

Die spanning maakt het soms moeilijk. Ze beperkt de ruimte voor communicatieve uitwisseling en het stellen van vragen op het gebied van zingeving en moraliteit. Maar het maakt deze vragen daarmee niet onzegbaar. Kunneman (1999) gebruikt de term trage vragen voor problemen die zich aan de logica van moderne technologische ontwikkelingen onttrekken, en die als zingevingsvragen worden aangeduid. Het gaat hem daarbij niet alleen om vragen rond ziekte, lijden en dood, maar om alle vragen die verbonden zijn met menselijke relaties, met liefde en trouw, maar ook met geweld en onverschilligheid en de wijze waarop mensen daarmee omgaan, er betekenis aan geven. Trage vragen dienen zich langzaam en onontkoombaar aan, los van en ondanks de dynamiek en de snelheid die de huidige tijd kenmerken. Waar geen snelle antwoorden mogelijk zijn worden zij weggeduwd naar het gebied van religieuze kaders en sociale politieke bewegingen, aldus Kunneman. Tegelijk lijkt het vanuit deze kaders steeds minder mogelijk de vragen te kanaliseren en antwoorden te vinden. Collectieve antwoorden op zingevingsvragen sluiten niet aan bij de individualisering van zingevingsprocessen die zich in de moderne tijd steeds verder doorzetten. Kunneman pleit voor de ontwikkeling van een sociaal milieu dat veilige ruimtes creëert waarin mensen hun ervaringen en vragen, 
hun eigen levensverhalen kunnen uitwisselen om gezamenlijk te zoeken naar nieuwe interpretaties van oude bronnen en tradities. Zijn opvattingen sluiten aan bij die van Giddens (2001), die het onderdrukken van morele- en zingevingsvragen als een van de uitkomsten van de ontwikkelingen in de moderne tijd beschouwt. Rationaliseringsprocessen hebben niet alleen bijgedragen aan individualisering, aan specialisering van kennis en vaardigheden, maar ook aan vervreemding van de morele bronnen en existentiële waarden die voorheen algemeen geldig waren en als heilig, onaantastbaar, werden beschouwd. Het vertrouwen in God of een andere hogere macht, werd verplaatst naar het vertrouwen in (specialistische) kennis en de groei van steeds meer mogelijkheden. Het vertrouwen in kennis en vooruitgang neemt de kwaliteit aan van geloof, waardoor mensen zich in tal van levenssituaties toevertrouwen aan de experts en zich daarbij veilig voelen (Belderok, 1997, Giddens, 2001).

Hoewel mensen altijd al experts hebben geraadpleegd, is door de verdergaande specialisatie de afstand tussen expert en leek veel groter geworden. Kon men vroeger in de eigen leefwereld praten en beschikken over kennis, door specialisatie zijn nieuwe afzonderlijke taalspelen gegroeid waardoor deze nieuwe kennis veel moeilijker toegankelijk werd voor leken (Giddens, 200r). Omdat mensen zich over het algemeen slechts in een zeer beperkt aantal kleine gebieden kan specialiseren, blijven de meeste abstracte kennissystemen ontoegankelijk en onbegrijpelijk voor de meerderheid van de mensen. Dit uit elkaar groeien van de leefwerelden waar mensen samenleven en de wereld van de systemen waar mensen werken en (specialistische) kennis vergaren, wordt aangevoerd als de oorzaak van vervreemding en isolatie van bronnen waaruit mensen kunnen putten om over zingeving, over eindigheid en kwetsbaarheid te praten en betekenis te geven aan moeilijke levenservaringen (Habermas, 1981, Giddens, 200r). Ook het omgaan met sterven en dood is meer en meer in handen van de medische professie gekomen en het spreken er over meestal als iets wat niet jezelf maar anderen betreft.

De ontwikkelingen van de moderne tijd hebben wellicht ten onrechte tot het idee geleid dat de (zorg)praktijk gerationaliseerd kan worden, uiteengezet in meetbare, kenbare onderdelen, voor elk specialisme wat wils. De praktijk echter laat zich niet van buitenaf 'kennen'. Zij heeft een eigen rationaliteit die vraagt (blijft vragen) om engagement, om communicatie en ruimte voor betekenisgeving (Widdershoven, 1995). Rationaliteit van wetenschappelijke kennis en beheersbare fenomenen stuit in de praktijk op grenzen. Grenzen die alleen toegang bieden voor wie zich met deze obstakels, vaak moeilijke levensvragen. wil verstaan door er mee in contact te treden om het proces van betekenisgeving aan te gaan. Om, waar woorden niet meer passend zijn of te kort schieten, te zoeken naar andere mogelijkheden het onzegbare te begrijpen of te benade- 
ren. Rituelen, esthetische voorstellingen, gedichten, afbeeldingen en muziek, maar ook gewoon nabijheid en aandacht voor de omgeving kunnen als communicatief instrument dienen om de toegankelijkheid van de wereld van zorgpraktijken te vergroten en grenzen te openen (Widdershoven, 1995).

Giddens' maatschappijtheoretisch gezichtspunt sluit hierbij aan. De rationalisering van de leefwereld is niet compleet, er blijven tendensen werkzaam om juist wat onderdrukt wordt, het spreken over menselijke ervaringen en zingeving, opnieuw een plek te geven.

Vanuit moreel onbehagen met de ontwikkelingen van de moderne tijd is de aandacht voor de palliatieve zorg ontstaan en is de hospice-beweging op gang gekomen, die ervoor koos het gezondheidssysteem te verlaten en de zorg voor stervenden weer een plaats te geven in de leefwereld (Janssens, 200I). Een ontwikkeling die Giddens (2001) life-politics noemt, een vermogen dat werkzaam is in mensen om bepaalde uit de leefwereld afgezonderde gebieden en vragen opnieuw ter sprake te brengen, langzaam en onontkoombaar. Het is een communicatief proces over waarden en normen, over vragen die, in het kader van de palliatieve zorg, te maken hebben met kwaliteit van leven, van sterven en van zorgverlenen. Belangrijk uitgangspunt bij de start en de ontwikkeling van palliatieve zorg, was de zorg te richten op een zo hoog mogelijke kwaliteit van het leven dat de patiënt nog rest, waarbij inbegrepen zorg en aandacht voor de mensen die in de directe kring rond de stervende belangrijk voor hem of haar zijn ( Doyle, 1993). Het is een uitgangspunt dat voortdurend afstemming en communicatief overleg vereist over de vorm en inhoud van die kwaliteit voor individuele patiënten en hun relaties en met de zorgverleners die in dit proces een rol spelen of daarvoor moeten worden ingeschakeld.

'Kwaliteit van leven' is een abstract begrip, dat door zorgvrager en zorgverlener verschillend kan worden ingevuld of gewaardeerd. Kwaliteit van leven, goede zorgverlening, het zijn theoretische uitgangspunten en tegelijk maken zij deel uit van concrete praktijken. Het is moeilijk absolute maatstaven te beschrijven voor kwaliteit van leven en voor kwaliteit van zorg. Kwaliteitszorg is een proces van communicatie (Widdershoven, 1997a). Theoretische uitgangspunten en regels voor de praktijk die in gezamenlijk overleg, op basis van inzicht en ervaringen tot stand zijn gekomen, vragen om toepassing in concrete situaties. Dit communicatieve proces, vraagt de aandacht en inzet van zorgverleners; het is een proces waarin professionele maatstaven en regels, maar ook persoonlijke achtergrond en opvattingen worden geconfronteerd met concrete situaties en individuele zorgvragen. Met andere woorden, om goede zorg te kunnen verlenen, om kwaliteit van leven te kunnen waarborgen, moet men het gesprek aangaan, is een houding vereist van responsiviteit en is ruimte voor reflectie nodig. Een houding die verbonden is met een levensinstelling, met life-politics, 
waarin kritische vragen, over kwaliteit, maar ook over kwetsbaarheid en emoties, blijvend mogen klinken en gehoord worden en waar trage vragen een stem krijgen en worden gewaardeerd. Een houding ook van openheid voor overleg en afstemming om uitgangspunten en opvattingen te verbinden met de praktijksituaties die elke dag weer anders kunnen zijn als doorgaand proces.

\subsection{Communicatieve macht en onmacht van zorgverlener en organisatie}

De palliatieve zorgpraktijk confronteert zorgverleners regelmatig met situaties waarin communicatie op grenzen stuit en het moeilijk is met de patiënt af te stemmen welke behoeften bij hem of haar op de voorgrond staan.

Mijnheer Van Vliet, is sinds twee maanden opgenomen in het hospice met uitgezaaide hersenmetastasen. Tumorgroei maakt het spreken moeilijk tot onmogelijk. Mijnheer Van Vliet slaapt veel, kan zich nauwelijks bewegen. Hij zit in een rolstoel, en moet met alles geholpen worden. Zijn vrouw wijkt niet van zijn zijde. Toen spreken nog mogelijk was en de ziekte in een minder ver gevorderd stadium, hebben zij beiden de situatie en de toekomst uitvoerig met elkaar besproken. Hij wilde zo lang mogelijk leven, zijn vrouw beloofde hem er op toe te zien, dat steeds alles in het werk zou worden gesteld om hem in leven te houden en de kwaliteit van die laatste periode steeds zo goed mogelijk te bewaken. Deze wensen zijn bij opname in het Hospice door zijn vrouw met het verzorgend team besproken en uitgelegd.

$\mathrm{Na}$ een verblijf van enkele weken echter krijgen zorgverleners meer en meer de indruk, dat 'het voor mijnheer Van Vliet allemaal niet meer hoeft'. Was er voordien nog enige reactie merkbaar als de fysiotherapeut, of andere zorgverleners bezig waren met zijn verzorging of met oefeningen voor het spreken, het lijkt hem nu te veel te worden. Een gesprek over hoe te handelen als zich opnieuw een complicatie voordoet, zoals een longontsteking, lokt steeds felle reacties uit bij de echtgenote. Zij zegt dat het de bedoeling is door te gaan met behandelen, 'dat heb ik met mijn man afgesproken.' Een gesprek tussen zorgverleners en patiênt is niet goed mogelijk.

De heer Van Vliet is fysiek niet meer in staat tot mondelinge communicatie. Omdat hij en zijn vrouw dit scenario hadden voorzien hebben zij met elkaar afgesproken hoe moet worden gehandeld. Voor de zorgverlening staat nu de geldigheid, de waarde van deze van te voren overeengekomen strategie ter dis- 
cussie. In de zorg voor de heer Van Vliet vangen zij signalen op die vragen bij hen oproepen. Zij zouden met hem willen overleggen hoe hij er nu over denkt. Hoe te handelen als hij als gevolg van zijn lichamelijke situatie een blaasontsteking of een longontsteking krijgt. Moeten zij in dat geval gaan behandelen met medicatie, of niet?

Mijnheer Van Vliet is niet in staat op die vragen in te gaan, de signalen die de zorgverleners opvangen geven hen onvoldoende houvast. Een gesprek met de echtgenote loopt vast op eerder gemaakte afspraken, waar zij aan wil vasthouden zonder de huidige situatie daarin te betrekken. Dit levert spanning en emoties op voor zowel zorgverleners als voor mevrouw Van Vliet. Een spanning als die tussen systeem en leefwereld, waar zorgverleners niet de ruimte krijgen om hun ervaringen en morele vragen te delen en het gesprek strandt op de regels die eerder door het echtpaar zijn vastgelegd. Zorgverleners voelen zich gefrustreerd en tekortschieten.

Het voorbeeld laat zien hoe emotionele betrokkenheid en professionele inzet met elkaar verbonden zijn. In de situatie rond de zorg voor de heer Van Vliet zijn het vooral de onbespreekbare emoties van de echtgenote die het voor de zorgverleners moeilijk maken tot een gelijkwaardige dialoog te komen. De stem van de heer Van Vliet wordt vertaald door zijn vrouw, zorgverleners hebben daar veel vragen bij. Misschien lukt het mevrouw Van Vliet ook niet onder woorden te brengen wat zij ten diepste als juist ervaart. Het is een voorbeeld van zorg als communicatief proces, waarin de vrije en gelijkwaardige communicatie (tussen zorgverleners en echtgenote) niet uitmondt in overeenstemming van wat kwaliteit van leven en van sterven inhoudt, of wat medisch zinvol of zinloos handelen betekent in deze specifieke situatie.

De moeilijkheden die communicatie belemmeren of onmogelijk maken, spelen zich niet alleen af op het niveau van individuen. Ook (zorg)organisaties spelen hierin een rol. Dit komt onder meer tot uitdrukking in beschikbaarheid van middelen, van mensen, tijd en ruimte. Kortom aan de regels en grenzen die men stelt aan het communicatief handelen. Én in de aandacht en mogelijkheden voor ondersteuning en begeleiding van zorgverleners (zorg voor de zorgenden), in hun taken en de gevoelens die de praktijkervaringen bij hen oproepen. Niet stil staan bij, of onvoldoende aandacht voor wat de praktijk bij hen oproept belemmert het proces van uitwisseling, van kritische reflectie op uitgangspunten, op beleid en praktijk en het gesprek hierover. Beleidsuitgangspunten en organisatorische regels, worden zo van bron en vertrekpunt van de zorgverlening, tot een belemmering voor communicatie en daarmee voor kwaliteit van zorg. 


\subsubsection{De taal}

Een ander probleem is de onmacht van het onder woorden kunnen brengen van ervaringen. Taal schiet voor mensen soms te kort om uit te drukken wat men ervaart of verlangt. De taal kan ook functioneren als dommekracht, als breekijzer dat vervormt in plaats van opent als het gaat om ervaringen die eerder oproepen tot zwijgen dan tot spreken. Een aanraking, nabij zijn, warmte en aandacht, kunnen soms meer betekenen dan vele zorgvuldig gekozen woorden.

Deze onmacht van taal als communicatiemiddel is in de filosofie vanuit verschillende perspectieven belicht. Van Asperen (1993) verwijst naar de moderne samenleving, waarin grote waarde gehecht wordt aan onafhankelijke zelfbepaling. Giddens (200I) noemt het mechanisme van afzondering van ervaringen uit het dagelijks (be)leven van mensen als oorzaak van het gegroeide onvermogen om deze ervaringen ter sprake te brengen en na te denken over de betekenis er van in het leven van mensen. Habermas (I98I) wijst op de kolonisering van de leefwereld door de instrumentele doelgerichte rationaliteit van de systeemwereld.

Deze instrumentele (Habermas; Giddens) en op zelfbepaling gerichte (Van Asperen) houding draagt er toe bij dat mensen niet alleen veel vrijheid hebben om te kiezen wat men wil zijn of wil worden. Ook datgene wat men niet wil, datgene wat mensen ongevraagd overkomt, wordt gezien en ervaren als iets wat mensen in de privé-sfeer moeten zien te klaren. Het is moeilijk geworden, aldus Van Asperen, over kwetsbaarheid te praten. $\mathrm{Zij}$ noemt dit de 'privatisering van het leed' en stelt dat er niet langer een gedeeld vocabulaire beschikbaar is waarin publiekelijk andere dan alleen materiële zaken besproken kunnen worden.

Ook Widdershoven brengt het gegroeide talige onvermogen en de grenzen van de in de gezondheidszorg gangbare opvatting van autonomie naar voren. Hij verwijst naar de zeggingskracht van esthetische uitingen. Als voorbeeld bespreekt hij een gedicht van Gerrit Achterberg en concludeert: het gedicht pleit voor een rehabilitatie van de taal in een wereld die zich richt op berekening. Het laat zien dat logische operaties mager afsteken bij talige uitingen, dat ze de werkelijkheid ten onrechte terugbrengen tot een wereld van winst en verlies en uiteindelijk geen greep krijgen op datgene wat er echt toe doet' (Widdershoven, 1995, p. 13).

Vanuit verschillende perspectieven wordt door auteurs gewezen op de effecten van het uit elkaar groeien van systeem en leefwereld en de spanning die dat meebrengt voor mensen die in hun dagelijks functioneren van beide werelden deel uitmaken. 
Kunneman (1998) daarentegen wijst niet zozeer naar de spanning tussen systeem en leefwereld als oorzaak van communicatieve onmacht, maar belicht deze vanuit een andere invalshoek. Hij verwijst naar de meervoudigheid van ons zelf. Mensen zijn niet alleen sprekende subjecten, zij hebben niet alleen een talige relatie met anderen en met zichzelf, maar ook een lichamelijke. Open en gelijkwaardige communicatieve verhoudingen vereisen naast bewustzijn van eigen opvattingen, waarden en normen, een emotionele en existentièle zelfverheldering van betrokkenen. Tegelijk kunnen niet alle ervaringen en gevoelens eenvoudig worden uitgedrukt in talige benoemingen. Nadenken over wat het goede leven inhoudt, over wat goede zorg is, vereist dat men rekening houdt met 'gaten in de taal' (Kunneman, 1998, p.29). Een niemandsland tussen het lichaam en de taal, waar signalen wel worden opgevangen maar taal niet toereikend is. Zijn idee is niet een nieuw vocabulaire ontwikkelen, maar een open ruimte laten voor dit ervaren, met een verwijzing naar het kind, of de ziel, als waardevolle eigenheid van mensen. Het gaat in de relatie met anderen, in het in gesprek zijn met anderen, niet alleen om communicatieve vaardigheden als spreken en luisteren. Even belangrijk is het, om ruimte te laten voor dit onuitspreekbare in onszelf en in anderen.

In het licht van Gadamers opvattingen van hermeneutiek wil ik de door Van Asperen en Kunneman beschreven beperkingen van het onder woorden kunnen brengen nader beschouwen. Van Asperen roept op tot het ontwikkelen van een seculier vocabulaire voor het aan de orde stellen van zingevingsvragen, zodat daar publiekelijk over gesproken kan worden. Als taak van de overheid ziet zij daarbij het in stand houden van waardevolle levensvormen, als bron voor deze woordenschat. Met het begrip levensvormen verwijst Van Asperen naar de manieren waarop mensen hun leven vormgeven vanuit een gemeenschappelijk ervaren achtergrond (Van Asperen, 1993. p.I68). Niet iedereen eigent zich vanuit die gemeenschappelijke traditie dezelfde waarden toe, maar het is die achtergrond die keuzen mogelijk makt en mensen levensvormen aanreikt.

Gadamer (1986) beschouwt de hermeneutiek als een reflectie op het menselijk leven als geheel (Begeman, 1995; Widdershoven, 2000a,b). De traditie, als onderdeel van de verschillende levensvormen, maakt deel uit van ons wereldbeeld, en krijgt vorm door onze gesitueerdheid in een bepaalde tijd en ruimte. Gadamer benadrukt dat traditie de achtergrond en tegelijk de horizon van het denken is. De bekendheid met de traditie maakt het mogelijk om de daarmee strijdige uitingen, opvattingen of ervaringen te herkennen. Ze nodigen uit tot een dialoog, waarvan de uitkomst van te voren niet vastligt, maar die kan leiden tot verbreding en verdieping van inzichten (van de horizon) van de gesprekspartners. Ervaringen zijn potentiële leerervaringen; door het gesprek 
aan te gaan kan zich zowel de betekenis van de traditie verdiepen, als de betekenis van ons huidige wereldbeeld waarin zich nieuwe ervaringen en vragen aan ons voordoen. Waar Gadamer mogelijkheden ziet voor het delen van ervaringen en daar leerprocessen aan koppelt, benadrukt Van Asperen het gevaar van beperkingen die er toe leiden dat mensen niet meer kunnen kiezen voor eigen levensvormen, waardoor afwijkende opvattingen geen plaats meer hebben en het spreken daarover steeds minder mogelijk wordt. Dit gebeurt wanneer de vrijheid van mensen wordt beperkt tot materiële vrijheid, geregeld door de overheid in toegang tot (zorg)voorzieningen en rechtvaardige verdeling van beschikbare middelen. Immateriële goederen als cultuur, tradities en levenswijzen hebben echter ook veel waarde en vragen om bescherming, hetgeen Van Asperen eveneens ziet als taak van de overheid.

Kunnemans kritiek op de mogelijkheden van communicatieve leerprocessen gaat verder. Hij pleit niet voor het ontwikkelen en in stand houden van verschillende manieren waarop mensen hun ideaal van goed leven vorm geven. Zijn stelling is dat niet alles in argumenten is uiteen te zetten. De mens heeft als sprekend subject, ook lichamelijke ervaringen en verlangens. Ook ervaringen van pijn en genieten, van verwondering en kwetsbaarheid, kracht en spiritualiteit laten onuitwisbare sporen achter op ieders levensweg. Het zijn ervaringen die mensen met zichzelf in contact brengen, een 'onafgestemd' weten wie we zijn, ervaringen waarvoor de taal te beperkt is. Dit niet-talig 'spreken' staat tegenover het spreken dat op basis van argumenten tot meer inzicht leidt, tegelijk maakt dit 'gesprek' met onszelf het mede mogelijk om waarachtig, om onszelf te zijn, in de omgang met anderen.

De bedenkingen van Kunneman zijn niet in tegenspraak met de hermeneutiek als leerproces. Ervaringen kunnen ter sprake komen en in het licht van onze voorkennis begrepen worden of uitnodigen tot verder onderzoek. Taal als instrument om de werkelijkheid uit te leggen is verankerd in onze traditie en cultuur en wordt daar tevens door begrensd. Waar de taal geen woorden voor heeft, blijft wel het ervaren, blijft er betekenis. Dit is geen geheimtaal: Ook het individuele ervaren van het lichamelijke, wat ons op een andere manier dan het rationele denken, in contact brengt met wie we zijn, kan in veel gevallen worden gedeeld met anderen. Gevoelens afstemmen op gevoelens, pijn op pijn, licht op licht en wat duister is op andere duisternis, kan net als het spreken tot verdieping en betekenis leiden, tot verbreding van het inzicht. Dit zonder woorden zichzelf of elkaar begrijpen, intuïtief weten dat nooit àlles gezegd kan worden, is iets wat mensen in en aan elkaar herkennen, waarin zij elkaar en zichzelf kunnen bevestigen en respecteren. Voorbeelden kunnen dit duidelijk maken, maar nooit helemaal. Ieder mens heeft deze, vaak kostbare, ervaringen. 
In de palliatieve zorg, waar mensen terugkijken op het leven en nadenken over betekenis van ervaringen van vroeger en van de situatie van nu en de nabije toekomst, zullen al deze aspecten een rol spelen. Zowel de mogelijkheden van gezamenlijk zoeken naar betekenis, in gesprekken, met behulp van voorstellingen, beelden, rituelen, maar ook van stil zwijgend nabij zijn, van herkennen en aanvaarden van wat eigen is aan de ander, kunnen helpend en helend zijn voor de patiënt en zijn naasten evenals voor de zorgverleners. De spanning tussen de rationaliteit van de systemen en die van de leefwereld zal daarbij steeds een rol spelen. Bewustzijn van de machtswerking die uitgaat van ongelijke verhoudingen en deze ter sprake brengen is een begin van een mogelijkheid om die spanning te verlichten. Bewustzijn daarnaast dat de begrensdheid en de ontoereikendheid van het talige benoemen van sommige ervaringen niet hoeft te betekenen dat deze ervaringen niet kunnen worden gedeeld met anderen, zal helpen meer oog te krijgen voor dit 'niemandsland' in het leven van zorgverleners en van de aan hun zorgen toevertrouwde patiënten.

\subsection{Communicatie op verschillende niveaus}

'In zorginstellingen zijn aanhoudend morele vragen aan de orde. Deze vragen doen zich voor op alle niveaus van de organisatie' (Van Dartel e.a., 200I, p. 5). Het herkennen van die vragen en het omgaan ermee vraagt om ruimte voor structurele vormen van communicatie en om een open klimaat waarin reflectie op praktijksituaties en op de normen en waarden die daarin een rol spelen regelmatig plaatsvindt. Dit zowel op micro- en mesoniveau, als ook op het macroniveau van overheid en organen van regelgeving. Morele vragen zijn niet enkel verbonden met de praktijk, het niveau van de relatie tussen zorgverleners en patiënten. De praktische werkzaamheid van ethiek in praktijk lijkt nauw samen te hangen met de kwaliteit van het communicatieve klimaat van de verschillende niveaus waarbinnen de zorg is georganiseerd.

Met behulp van een praktijkvoorbeeld vanuit het St. Raphaëls Hospitz (Wenen, 1997) wordt nagegaan welke vormen van overleg en reflectie bevorderd, dan wel geïnstitutionaliseerd zouden moeten worden en wat daar op de verschillende niveaus voor nodig is.

Het praktijkvoorbeeld

Mevrouw Baden ligt op een twee persoonskamer. De eerste maanden ligt ze bij de deur. Toen haar kamergenote overleed is haar bed bij het raam gezet. Uiteindelijk verbleef zij meer dan drie maanden in het hospice. Mevrouw 
Baden is 45 jaar, de kanker waaraan zij lijdt heeft zich uitgezaaid en een van de gevolgen daarvan is een dwarslaesie. Vanaf het midden van haar rug is zij verlamd. Dagelijks wordt ze, na de lichamelijke verzorging, in de rolstoel geholpen. Meestal gaat ze dan naar het dagverbliif om er te schilderen en te roken. Mevrouw is getrouwd en heeft een dochter van 19 jaar, over wie ze zich veel zorgen maakt. Haar huwelijk is niet gelukkig. Haar man is ook ziek en bovendien verslaafd aan alcohol. "Hij wil dood", vertelde ze me, "en ik wil leven."

Mevrouw heeft geen pijn, maar de ziekte sluipt voort en het schilderen lukt niet altijd meer, hier lijdt zij erg onder. Als ze hele dagen aan bed gekluisterd is, praat ze er toch steeds over dat ze verder wil met schilderen, of lekkere dingen bakken, en over haar dochter.

Een heftige darmbloeding zorgt op een dag voor een situatie waar acuut moet worden ingegrepen. Mevrouw wordt zodanig gesedeerd 5 dat zij in een slaaptoestand komt te verkeren. De situatie wordt daarna weer stabiel, het bloeden is gestopt.

$\mathrm{Na}$ ongeveer 10 dagen is mevrouw rustig, in haar 'slaap', overleden.

\subsection{Microniveau: de relatie zorgverlener(s) -patiënten en naasten}

Het voorbeeld van mevrouw Baden werd voorgelegd aan zorgverleners in het hospice waar ik, vanaf september 1999 tot oktober 2000 , veldwerk voor dit onderzoek heb verricht. Vragen die ik daarbij stelde waren: zou deze situatie een probleem zijn voor $u$ ? En: Hoe zou u omgaan met deze situatie? De antwoorden waren vrijwel gelijkluidend en kwamen neer op

- Ja, de situatie is problematisch. Aan mevrouw Baden kon niet worden gevraagd of zij dit zo wilde. Er was voor haar geen gelegenheid meer om

5 Er bestaan diverse termen voor sedatie, Gewoon 'sedatie' of 'diepe sedatie', 'terminale sedatie', 'gecontroleerde sedatie', 'therapeutische sedatie' of 'palliatieve sedatie' (Bruntink. 2002). Het sederen van patiënten in geval van onbehandelbaar ernstig lijden, is in een aantal gevallen het laatste middel dat wordt ingezet om lijden van terminaal zieken draaglijk te maken. Het gaat om het draaglijk maken van symptomen die leven tot lijden reduceren (Dondeyne, 2002). De beslissing tot sedatie, met uitzondering van acute situaties waar snel ingrijpen verlangd wordt, dient pas na zorgvuldig overleg tussen alle betrokkenen te worden genomen. Goede communicatie tussen het zorgverlenend team, de patiēnt en zijn of haar familie is hierbij een noodzakelijk vereiste (Schotmans, 2000). Een patiēnt die gesedeerd wordt, kan zich op dat bewustzijnsniveau niet uiten. Ook eten en drinken is minder mogelijk. Is sedatie niet de oorzaak van het overlijden, het overlijden kan er wel door worden bespoedigd. In deze situaties wordt gesproken van 'dubbel effect' (Janssens, 2001). 
afscheid te nemen van haar dochter, of om met haar nog dingen te bespreken, af te ronden. Er is geen communicatie meer mogelijk met haar naasten.

- De reacties op de vraag 'Hoe omgaan met de situatie' varieerden van 'de situatie ter discussie stellen in het team' tot 'mevrouw toch weer laten ontwaken en kijken waar ze nog aan wil werken. Eventueel met hulp van ons een gesprek organiseren met haar dochter. Het gaat om wat mevrouw Baden zelf wil. Nu wordt over haar beslist.'

\subsubsection{Communicatie op microniveau}

In een responsieve zorgpraktijk, waar men de belangen van de patiënt centraal stelt, is de patiënt, hier mevrouw Baden, een reële deelnemer aan het gesprek over de kwaliteit en de inrichting van de zorgverlening (Widdershoven, 1997b). Door als zorgverlener eenzijdig de beslissing te nemen welke zorg, welk probleem het eerste aandacht verdient en ook als zorgverlener(s) zelf te bepalen wat daarin de juiste handelwijze is, wordt degene om wie het gaat buiten spel gezet. Haar beleven van goed leven en goed sterven wordt niet gehoord.

In de palliatieve zorgpraktijk hebben steeds verschillende mensen, of groepen van mensen met elkaar te maken. Zij werken samen in het proces van zorgverlenen: professionele zorgverleners en vrijwilligers, patiënten en hun partners, ouders, familieleden en vrienden. Al die relaties brengen verantwoordelijkheden met zich mee, die op hun beurt kunnen botsen, of vragen oproepen. Onderlinge communicatie en reflectie op situaties die mensen, samen of individueel, in de zorgverlening meemaken, dragen bij tot een breed en zo veel mogelijk gedeeld inzicht. Communicatie, onmisbaar in het aangaan van relaties in die individuele zorgprocessen, is een noodzakelijke voorwaarde daarvoor. Het vraagt attituden en vaardigheden die echter niet altijd en gelijktijdig aanwezig zijn in mensen die vanuit verschillend perspectief in de zorgpraktijk bij elkaar betrokken zijn en samenwerken. De spanning tussen de formele regels en opvattingen van de organisatie en de leefwereldcontext vraagt ook zijn tol op het gebied van de kwaliteit van de communicatie en de mogelijkheden van gelijkwaardig overleg.

Verkerk (2000, p. II7) wijst erop dat een organisatie oog dient te hebben voor die verschillende en soms botsende verantwoordelijkheden. Zij pleit ervoor dat op de werkvloer een plaats wordt ingeruimd voor morele reflectie. Dat men voorwaarden creëert om te spreken over ervaringen als met mevrouw Baden en de heer Van Vliet en de ethische vragen die zij oproepen. Ook hier geldt dat alleen het beschikbaar stellen van tijd en geld voor ethisch overleg niet vol- 
doende is. De mensen waarom het gaat, zorgverleners en andere betrokkenen, moeten wellicht ook worden toegerust om een dergelijk overleg te kunnen voeren. Niet iedereen beschikt over de communicatieve kwaliteiten die nodig zijn voor gelijkwaardig overleg en reflectie op situaties en de waarden die daarbij in het spel zijn. Binnen een team van zorgverleners zijn onderscheiden machtsposities aan de orde, die gemakkelijk een stempel drukken op de vorm en inhoud van de discussie en daarmee op de meningsvorming. Voorlichting, scholing en begeleiding zijn instrumenten om een team hierin te ondersteunen.

Regelmatig terugkerend ethisch overleg schept mogelijkheden om te leren van ethische vragen, zoals dat met medisch-technische vragen en ervaringen ook gewoon is. Ethische vragen zullen vaak hetzelfde zijn maar toch ook anders, omdat het steeds gaat om de beleving en de achtergrond van individuele mensen in specifieke situaties. Ethisch overleg en reflectie bieden mogelijkheden om te leren van elkaars inzichten. Ook regels en systeemeisen worden in het gesprek betrokken en besproken in het licht van concrete doorleefde ervaringen. Zo blijven systeemeisen niet alleen gericht op het in standhouden van organisaties en systemen, maar worden zij tevens betrokken op de praktijk van zorg. Zo kunnen zij buigzaam worden om zich te verhouden met de problemen en de ervaringen van mensen die het betreft. Dit zal de spanning tussen systeem en leefwereld verminderen.

Het ethisch overleg zou een gelijkwaardige plaats moeten krijgen binnen of naast het structurele medisch verpleegkundig overleg over begeleiding en behandeling van patiënten.

\subsubsection{De spanning tussen systeem en leefwereld}

Een ideale overlegsituatie, waarin alle relevante elementen en eventuele gevolgen of achtergronden ervan aan bod komen voor een weloverwogen oordeel, of om achteraf moeilijke situaties alsnog tegen het licht te houden, kan lang niet altijd worden gerealiseerd. Ervaringen en behoeften, expliciete en onderhuidse vragen botsen op systeemeisen en onvermogen om er mee voor het voetlicht te komen. Verschillende machtsposities, botsende verantwoordelijkheden zijn factoren die gelijkwaardige communicatie gemakkelijk verstoren. De spanning tussen systeem en leefwereld speelt in de dagelijkse praktijk een belangrijke rol.

De situatie van mevrouw Baden roept bij zorgverleners, wanneer zij de tekst lezen, onmiddellijk de vraag op naar de (zorg)behoeften van de patiënte en haar naasten. Deze reactie verwijst naar het eerste morele aspect van zorg 
'attentiveness'(Tronto, 1993), als kwaliteit van opmerkzaamheid, attent zijn. Ieder mens is ermee toegerust, maar in de praktijk is het vaak gemakkelijker de eigen behoeften of de eigen opvattingen van wat die behoeften zouden moeten zijn, centraal te stellen. Of om een andere kant op te kijken als iemand in nood is. Daarom noemt Tronto 'attentiveness', het herkennen van de behoeften van mensen om ons heen, een morele prestatie. Om dat te kunnen is een zekere levenservaring nodig. Het even los kunnen laten van eigen behoeften om open te staan voor anderen. Het zien of herkennen van de nood van anderen doet een beroep op de verantwoordelijkheid. De morele vraag waar zorgverleners zich voor gesteld zien is niet 'wat zijn we aan anderen verplicht', maar 'hoe kan ik mijn verantwoordelijkheid voor de ander gestalte geven?' (Verkerk, 2000, p. 114). Wat die verantwoordelijkheid is varieert, afhankelijk van wie bij een bepaalde praktijksituatie betrokken zijn en welke behoeften of problemen zich daarin voordoen. Tronto definieert zorg als 'een activiteit die erop gericht is alles te doen wat in ons vermogen ligt, om onze wereld in stand te houden, te continueren en te repareren, zodat we er zo goed mogelijk in kunnen leven' (Tronto, I993, p.I03). Vertaald naar de palliatieve praktijk betekent dat, dat zorgverleners alles zullen doen om goed leven en goed sterven voor degenen die op hen zijn aangewezen, mogelijk te maken. Zorg wordt vanuit dit gezichtspunt opgevat als een sociale/relationele en praktische aangelegenheid. Vanuit een betrokkenheid met die specifieke praktijk gaat men zorgrelaties aan en wordt gewerkt aan kwaliteit van die wereld als geheel en aan kwaliteit van elk individueel zorgproces. Regels en principes zijn noodzakelijke en belangrijke hulpmiddelen voor het handelen in het algemeen, maar functioneren vaak pas 'achteraf' en vragen interpretatie per situatie (Nussbaum, 1998, p. 17-19).

In de situatie van mevrouw Baden bijvoorbeeld heeft men pas toen het acute probleem van ernstig lichamelijk lijden zich voordeed, daarop gereageerd met een ingreep om dat lijden te verzachten. Anticiperend op een mogelijke crisissituatie had men wellicht ook eerder iets met de signalen van mevrouw Baden kunnen doen: de zorgen om haar dochter en haar sterke wens aan het leven vast te houden. De mogelijkheid van een acute darmbloeding en hoe in zo'n situatie te handelen hadden wellicht vooraf met haar besproken kunnen worden. Op die wijze had de patiënte kunnen deelnemen aan het gesprek over de vraag wat kwaliteit en goede zorg is en had men daarover afspraken kunnen maken.

Of is dit een te ideale voorstelling van de mogelijkheden in de praktijk? Uit de reacties van de zorgverleners op de casus klinkt een gevoel van onbehagen, de 
situatie is problematisch. Ook dit is een reactie achteraf. In de werkelijkheid is het blijkbaar moeilijker om de problemen en vragen te herkennen en helder te formuleren. Dit ondanks een klimaat waarin gelijkwaardige communicatie en respect voor de inbreng van andere betrokkenen hoog in het vaandel staat. Kunneman verwijst in dit kader naar de effecten van de (snelle) tijd waarin we leven. 'De logica van de versnelling en technologische vernieuwing die de huidige tijd kenmerkt, onttrekt zich aan problemen die als zingevingsvragen worden aangeduid' (Kunneman I999, p.9). Trage vragen, noemt hij het, omdat zij het tegendeel vormen van de versnelling die de technologie kenmerkt. Met andere woorden: technische oplossingen en mogelijkheden zijn sneller voorhanden dan de vragen (en antwoorden) over de zin, de wenselijkheid en de betekenis ervan voor de mensen om wie het gaat. Toch dienen die vragen zich onontkoombaar aan, worstelen mensen met ervaringen en problemen die zij tegenkwamen, om alsnog antwoorden te vinden.

\subsection{Mesoniveau: zorgverlenen binnen een zorginstelling}

Palliatieve zorgverlening vindt plaats op de plek waar de patiënt op dat moment verblijft: thuis, in een hospice, een palliatieve unit in een verzorgingsof verpleeghuis, of in een ziekenhuis. Moraliteit is niet iets wat begint en eindigt bij de zorgverleners in hun contacten met patiënten en familie. 'Niet langer worden de verantwoordelijkheden exclusief neergelegd bij de beroepsbeoefenaren, of de overheid, maar worden zij ook toegedeeld aan directies en koepelorganisaties.' Volgens de Raad voor de Volksgezondheid en Zorg impliceert ethiek in instellingen een directe verantwoordelijkheid van directies. De Raad adviseert het ethiekbeleid onder te brengen in het kwaliteitsbeleid van de organisatie. Een aanbeveling die door de minister van VWS werd overgenomen (Van Dartel e.a., 2001, p. 5).

De organisatie, het management van de zorginstelling draagt formeel verantwoordelijkheid voor de kwaliteit van het verblijf van patiënten en hun familie, voor de beschikbaarheid van middelen en voor het organiseren van voorwaarden om goede zorg te verlenen. Zowel op het niveau van het management als op dat van beleidsontwikkeling komen ethische kwesties aan de orde. Verkerk pleit ervoor dat het management ruimte biedt aan zorgverleners voor het bewustworden van de ethische dimensies van het werk en hen in staat stelt morele vraagstukken op te lossen. Hiertoe moet aan een zodanige institutionele vormgeving worden gewerkt, dat de morele dimensies van de dagelijkse zorgverlening ruimte krijgen om tot uitdrukking te komen (Verkerk, 2000, p.I2O-I2I). 
Een instelling legt haar visie op kwaliteit van zorgverlenen, op wat wenselijk en menswaardig is, op mogelijkheden en grenzen van de organisatie, in de meeste gevallen neer in een beleidsplan, dat tevens richtlijn is voor het wervings- en selectiebeleid. Ten aanzien van opname en verblijf van patiënten worden door de organisatie uitgangspunten geformuleerd, mogelijkheden en grenzen vastgelegd. Deze taken vloeien voort uit de verantwoordelijkheid van het management voor goede zorgverlening en het in stand houden van de organisatie. In de praktijk tonen deze uitgangspunten hun waarde en hun beperkingen.

Tronto maakt ten aanzien van het begrip verantwoordelijkheid het onderscheid tussen verantwoordelijkheid louter als het volgen van vastgelegde regels en verplichtingen en een breder, flexibel concept van verantwoordelijkheid. De zorg-verantwoordelijkheid berust tenslotte, zegt zij, op een veelheid van factoren. Zorgdragen voor anderen en voor de wereld om ons heen is veel meer een culturele praktijk dan een opvolging van formele regels en verwachtingen (Tronto, 1993). Vanuit dit brede concept van verantwoordelijkheid hebben organisaties een voorwaardenscheppende taak voor het zorgvuldig moreel handelen in de respectievelijke zorgpraktijken.

Verkerk (2000, p.I12) noemt in dit licht een aantal managementtaken die voortvloeien uit de toenemende verantwoordelijkheid voor morele vraagstukken in zorgorganisaties: het expliciteren van morele vragen, het initiëren van overleg over normen en waarden en het ontwikkelen van een integrerende normatieve visie die richting kan geven aan de keuzeprocessen die in de organisatie plaatsvinden.

\subsubsection{Communicatie op mesoniveau}

De zorginstelling biedt daarmee een kader van regels en protocollen, een achtergrond van waarden en normen aan zorgverleners en ziet hen als gesprekspartners in een praktijk waarin zorg wordt verleend en kwaliteit wordt nagestreefd. Communicatie over en ethische reflectie op de praktijk en de moeilijke situaties die zich daarin voordoen, verschaffen zowel zorgverleners als managementfunctionarissen de mogelijkheid om deze bronnen, deze uitgangspunten en regels helder en levend te houden en beleid zo nodig bij te stellen.

Ethiek en reflectie liggen in elkaars verlengde. De letterlijke betekenis van reflectie is terugkaatsing: het licht dat ergens op wordt gericht, kaatst terug in het beeld dat daaruit verschijnt. Door overdenken en bespreken van dagelijkse ervaringen in het licht van de normen en waarden die voor betrokkenen een rol spelen, kan men voor zichzelf en voor anderen de betekenis ervan verhelderen 
en zo nodig het handelen of de beleidsuitgangspunten bijstellen. Dit klinkt wellicht eenvoudiger dan het in de werkelijkheid is. In Ethiek in Commissie, van Verweij e.a. (1999, p. 49) worden de kenmerkende aspecten van morele reflectie op een rij gezet:

- Morele reflectie gaat over zaken die er voor mensen 'werkelijk toe doen'. Het gaat uit van een betrokkenheid van de deelnemers bij het onderwerp dat ter discussie staat;

- Morele reflectie is complex. De complexiteit ervan ligt vooral in het op zuivere wijze articuleren van argumenten;

- Het resultaat van morele reflectie kan bedreigend zijn voor gevestigde belangen. Bijvoorbeeld als een voorgenomen onderzoek in een palliatieve setting moreel onaanvaardbaar is;

- Morele reflectie kan erg 'dichtbij' komen. De discussie gaat over normen en waarden, een vrijblijvende en afstandelijke opstelling verhoudt zich daar niet mee;

- Morele reflectie heeft betrekking op 'goed' en 'kwaad', waardoor het al snel tot een 'zware' aangelegenheid wordt.

Hoewel niet altijd gemakkelijk, is morele reflectie wel noodzakelijk. Waar geen ruimte beschikbaar is en het communicatieve klimaat onvoldoende om vragen te stellen en ervaringen te delen, worden zorgverleners en andere betrokkenen geconfronteerd met gevoelens van onmacht. Gevoelens die in de praktijk, in de opeenvolging van gebeurtenissen en het beroep wat ervan uit gaat, weinig ruimte krijgen om bij stil te staan en onderling uit te wisselen. Dit is vooral zo als er geen kaders aanwezig zijn, als bezinning en reflectie geen structureel onderdeel vormen van de zorgpraktijk. De vragen die blijven liggen, stapelen zich op in mensen. Ze dragen ze mee naar huis en weer terug naar hun werk, een last die steeds zwaarder wordt en mensen kan doen 'opbranden' (Kunneman, 1998).

Mevrouw Baden, uit het praktijkvoorbeeld, maakte deel uit van de palliatieve praktijk, waarin gespecialiseerde zorg beschikbaar is. Het is een veilige wereld, die voldoet aan de verwachtingen. Als zich de acute darmbloeding voordoet, stokt echter het gesprek zowel met mevrouw Baden, met haar familie, maar ook met de organisatie. Zorgverleners die dit herkennen voelen zich ongemakkelijk bij deze situatie en vragen zich af of er geen betere afstemming van behoeften en van verantwoording van het ingrijpen, had moeten plaatsvinden.

In de meeste zorgpraktijken is het inmiddels heel gewoon dat regelmatig interdisciplinair overleg plaatsvindt over de zorgsituaties van dat moment met 
terugblikken op voorbije ervaringen. Dit is echter geen garantie dat dit altijd de benodigde ruimte oplevert voor reflectie op ethische vragen van de mensen die het meest bij de dagelijkse zorg betrokken zijn, zoals verpleegkundigen en mantelzorgers. In zo'n overleg worden feiten naar voren gebracht, terwijl mensen juist als het om existentiële en morele vragen gaat, hun onbehagen of onmacht niet altijd gemakkelijk in volzinnen kunnen uiten. In trage vragen, een in zichzelf gekeerd gelaat, in vermoeide, afhangende schouders toont zich dat onbehagen vaak eerder. Dit te verstaan, is moeilijker. Het vraagt tijd, opmerkzame aandacht en gevoeligheid voor deze signalen. lets wat in de moderne tijd met zijn snelle ontwikkelingen en steeds onbeperktere mogelijkheden, onder druk is komen te staan.

De vruchtbaarheid van onderling overleg tussen de verschillende bij de zorg betrokken disciplines is afhankelijk van de kwaliteit van de communicatie. Ook Tronto (1993) wijst hierop. De door haar beschreven fasen in het zorgproces vragen om openheid, attent zijn voor (zorg)vragen, verantwoordelijkheid, competentie en wederkerigheid. Het zijn morele kwaliteiten die niet alleen van toepassing zijn op zorg voor anderen. Ook in de zorg voor zichzelf komen deze kwaliteiten van pas. Wanneer het zich ongemakkelijk voelen met een situatie, de vragen die dat oproept bij de zorgverlener leiden tot bewust ervaren en herkennen van die gevoelens, pas dan kunnen deze vragen worden ingebracht en gedeeld met anderen. Een proces waarbij het management behulpzaam kan zijn door een open houding naar praktijk en zorgverleners, aandacht niet alleen voor de organisatie en het sturen daarvan, maar juist ook voor de mensen en hun ervaringen, een gedeelde visie op kwaliteit van zorg en het aanbieden van een structuur voor regelmatig ethisch overleg.

\subsubsection{De spanning tussen systeem en leefwereld}

Het bewustzijn van de eigen achtergrond, motivatie en de normen en waarden die mensen met zich meedragen, is een noodzakelijke voorwaarde voor het herkennen, interpreteren en leren van uitingen van anderen en van situaties die zich in de praktijk voordoen. Een hermeneutische houding, die mensen in staat stelt afwijkende meningen of oplossingen te herkennen, zich te verwonderen en het gesprek aan te gaan. Dit geldt ook voor de organisaties. De organisatie van zorg is belangrijk. Zonder goede structuur valt het zorgsysteem uit elkaar, maar daarbinnen is ruimte nodig voor kwaliteit, voor datgene wat zorg eigenlijk is of zou moeten zijn. Ontwikkelen van beleid, nadenken over waarden en normen, het vaststellen van protocollen kan niet los van de praktijk en beleving, de ervaringen van direct betrokkenen, plaatsvinden. Organisaties 
dragen daarbij de verantwoordelijkheid die praktijken zodanig in te richten en te ondersteunen, dat de kwaliteiten die zorgverleners voor dat uitwisselings- en leerproces meebrengen en nodig hebben, verder worden ontwikkeld en ondersteund. Om op die wijze te zoeken naar overeenstemming over wat kwaliteit van zorgverlening inhoudt en wat geoorloofd en goed is in het algemeen en in specifieke (zorg)situaties. Vanuit het zorgethisch perspectief is het nooit voldoende alleen middelen ter beschikking te stellen (Tronto, 1993). Het gaat in de zorg niet alleen om instrumentele vaardigheden, niet alleen om de technische kwaliteit van dingen die moeten worden gedaan, maar ook om de vraag of de goede dingen worden gedaan, de morele kwaliteit van de zorgverlening. De spanning tussen het systeem- en leefwerelddenken, tussen in stand houden en ontwikkelen, blijft onderdeel van het interactieproces tussen de verschillende actoren in een organisatie. Soms aanzettend tot kritische reflectie, soms de communicatie begrenzend. Waar theoretische modellen als hermeneutiek en zorgethiek voorstellen doen voor oplossingen van die beperkingen, vraagt de praktijk ook stil te staan bij de ontoereikendheid van de vooronderstelllingen waarvan zij uitgaan. Een spanning die zich niet laat wegredeneren, maar realiteit is van dagelijkse omgang met de praktijk.

Het begrip van wat goede zorg is, blijkt veranderlijk en ontstaat steeds opnieuw in de praktijk, door interpreteren en afstemmen. Niet alleen tussen zorgverleners en patiënten, maar ook tussen zorgverleners onderling en met het management van de organisatie. Tenslotte berust het nadenken over en organiseren van wat als goede zorg wordt gezien, op een maatschappelijke verantwoordelijkheid.

\subsection{Macroniveau: de zorgorganisaties en de overheid}

Het concept van zorg opvatten zoals Tronto beschrijft, als een activiteit die erop gericht is alles te doen wat in ons vermogen ligt om onze wereld in stand te houden, te continueren en te repareren, zodat we er zo goed mogelijk in kunnen leven, houdt in dat dit zorgen niet is voorbehouden aan bepaalde groepen of individuen. De gehele samenleving is hierbij betrokken. Deze universele morele claim is verbonden met een relationeel mensbeeld. Mensen zijn op elkaar aangewezen. De claim van zorgende betrokkenheid bij anderen is niet alleen herkenbaar in een professionele omgeving. In sociale praktijken als die van de mantelzorg, vrijwillige hulp aan ouderen en alleenstaanden, maar ook in vriendschapsrelaties en relaties tussen ouders en kinderen speelt die betrokkenheid een rol. De afwezigheid van deze morele kwaliteit valt op in relaties waarin geweld en verwaarlozing een rol spelen (Tronto, 1993: Walker, 1998). 
Het zijn juist de praktijkvoorbeelden, de ervaringen van mensen, die duidelijk maken dat een daadwerkelijke praktijk van zorg naast de vaststelling van feiten en behoeften, kwaliteiten van mensen vraagt om zorgvragen niet alleen te herkennen maar er ook iets mee te doen.

Palliatieve zorg, zorg voor mensen in de laatste fase van het leven, is niet iets nieuws. Hoewel het spreken over ziekte en dood en over kwaliteit van leven en sterven meestal over anderen gaat, is het iets wat ieder mens betreft. De vorming van aparte wetenschappelijke deelgebieden, de specialisaties in de gezondheidszorg, institutionalisering en het daarmee gepaard gaande afzonderen van ervaringen die vroeger deel uitmaakten van het dagelijks bestaan, hebben geleid tot vervreemding van die ervaringen (Giddens, 200r).

Het sterven van mensen vond meer en meer plaats in ziekenhuizen in plaats van thuis, waar de zieke werd omringd en verzorgd door familie. Dit leidde tot situaties die op den duur een moreel onbehagen opriepen bij de zorgverleners en nabestaanden. Vervreemding en onderdrukking van de morele en existentiële dimensies van het bestaan leidden tot nieuwe vragen over zin en waarde van het leven en van de ervaringen van mensen. Dit tegen de druk van regels en systemen in steeds weer opborrelen van morele vragen heeft er het laatste decennium onder meer toe geleid, dat de palliatieve zorg zich, als zorgvoorziening in Nederland, los van het bestaande systeem van gezondheidszorg, ging ontwikkelen en op de agenda van de overheid en met name op die van het Ministerie van Volksgezondheid werd geplaatst (NPTN, 1996). Gestuurd door de praktijk, waar initiatieven ontstonden om het opnieuw mogelijk te maken dat mensen thuis kunnen sterven of, wanneer de verzorging daar niet langer toereikend was, een plek te creëren waar zij zich, met directe naasten, veilig wisten en verzorg konden worden, werd deze zorgvoorziening op den duur door de overheid erkend.

\subsubsection{Communicatie op macroniveau}

Zoals de praktijk van zorg een doorlopend proces is, geldt dat ook voor de communicatie die nodig is om beleid, voorzieningen en praktijk op elkaar af te stemmen. Voortdurend en rechtstreeks in gesprek blijven met zorgpraktijken, biedt de overheid de mogelijkheid de eigen achtergrond en horizon te verrijken met de ervaringen en inzichten van mensen die zorg geven en zorg ontvangen. Een wederzijds proces, dat ruimte maakt om regels en voorzieningen steeds te zien en af te stemmen in het licht van de behoeften uit de praktijk. Gesprekken daarover zullen de deelnemers daaraan voortdurend voor normatieve keuzes plaatsen (Kunneman, 1996). Dit vraagt zowel van de overheid als van de zorg. 
organisaties een open houding tegenover nieuwę opvattingen en ervaringen. Het gaat daarbij niet alleen om medisch- technische problemen of oplossingen. Een gelijkwaardige plaats moet worden ingeruimd voor morele en existentiële vragen die met de zorg zijn verbonden. De praktijk van de zorgverlening houdt op die manier de mogelijkheid het rationele, efficiënte en op resultaat gerichte denken en handelen van moderne (zorg)organisaties te verbinden met de communicatieve existentiële en normatief geladen belevingswereld van mensen die daarin beroepsmatig of als patiënt betrokken zijn. Geen eenvoudige opgave, want de praktijk spreekt langzaam en veelkleurig, terwijl het op resultaat gerichte denken meestal snel is en rechtlijnig. Toch zouden management en bestuurders van organisaties in gesprek met zowel de mensen op de werkvloer als met beleidsmakers op overheidsniveau de kaders kunnen helpen creëren en onderhouden voor een samenspraak tussen zorgpraktijken en overheid cq. samenleving.

De praktijk van zorg is niet alleen een moreel concept, het heeft ook een politieke betekenis: 'to recognize the value of care calls into question the structure of values in our society. Care is a central concern in human life.'(Tronto, I993, p. I78)

Attentiveness en responsiveness vragen om betrokkenheid, een met elkaar in gesprek zijn. Responsiveness is verbonden met de activiteit van de zorgontvanger. Responsiveness betekent een actieve en morele houding van wederkerig. heid, een voortdurend afwegen van behoeften van zorgvrager (op dit niveau: de zorgorganisaties) en de mogelijkheden van de zorgverlener (hier: de overheid) ten aanzien van behoeften en mogelijkheden. In het politiek en maatschappelijk debat over wat wenselijk is, wat kan en mag en over wat juist niet geoorloofd is in de zorg, zijn de ervaringen, de verhalen uit de praktijk onmisbaar. Het zijn verhalen van anderen, tegelijk gaat het over onszelf. Juist die verhalen maken duidelijk waarom het gaat in individuele situaties waar mensen in nood zijn, welk beroep er van hen uitgaat en wat in die specifieke situaties geboden is. Het gaat daarbij niet alleen om extreme situaties, waar patiënten of familie de publiciteit zoeken om een noodsituatie bekend te maken. Zoals wachttijden, die te hoog oplopen, omdat de organisatie hapert en er onvoldoende professionals beschikbaar zijn. Het gaat veel meer om de fundamentele vraag hoe wij in onze samenleving denken over wat 'goede zorg' is, wat 'goed sterven', wat 'goed (samen)leven' betekent. De antwoorden daarop komen niet uit de lucht vallen, maar zijn het resultaat van een samenspraak, waarin praktijkervaringen zoals de situatie van mevrouw Baden, de vragen en behoeften die daar spelen, een stem hebben en meewegen in besluit en beleidsvorming op het niveau van de overheid.

Of en wanneer die verhalen de overheid en de samenleving bereiken is nog de 
vraag. De werkelijkheid is geen ideaal plaatje. Tronto (1993), maar ook Habermas (1981), Kunneman(1998), Begeman (1995) en Van Asperen (1993) wijzen op de grenzen die een dergelijke dialoog belemmeren. Grenzen tussen privé- en publiek, moraal- en politiek, systeem en leefwereld, theorie en praktijk als afzonderlijke domeinen. De taal die in de leefwereld gesproken wordt is niet altijd de taal van de instituten. Het herkennen van deze barrières is wel een begin van een gesprek.

Voorbeelden van initiatieven (NPTN, 2002) om de praktijk, de ervaringen en opvattingen die daar leven meer in beeld te brengen van de gehele samenleving om een breed maatschappelijk draagvlak te creëren en politieke aandacht te vragen, zijn

- Plannen om in het voorjaar van 2003 'een week van de palliatieve zorg' te organiseren, waarbij zorginstellingen worden opengesteld en mensen worden uitgenodigd binnen te komen;

- Het organiseren van regionale bijeenkomsten waar zorgverleners, zorgorganisaties en patiëntenorganisaties ervaringen en behoeften uitwisselen;

- Aandacht in de media, in de sport en in de kunst voor de thema's zorg, kwaliteit van leven en kwaliteit van sterven.

\subsubsection{Spanning tussen systeem en leefwereld}

Hoewel de palliatieve zorg zich zeker in de beginperiode helder onderscheidde van andere medische praktijken en ervoor koos het formele gezondheidszorgsysteem te verlaten, was het de intentie van de pioniers om hun filosofie van zorg, te herintegreren in de gezondheidszorg. Belangrijke waarden die hen daarbij voor ogen stonden waren het concept 'totale zorg' en de acceptatie van menselijke kwetsbaarheid en sterfelijkheid. Sterven, verlies en kwetsbaarheid weer een plaats geven in de leefwereld van mensen én op een leefbare, reflectieve manier een gelijkwaardige positie binnen het systeem van de gezondheidszorg. Dit is geen eenzijdig proces dat gerealiseerd kan worden door alleen de inzet van betrokken en invoelende zorgverleners, het is een proces waarvoor politieke keuzen gemaakt moeten worden. 'De minister van VWS zou haar of zijn oor meer te luisteren moeten leggen bij de sector zelf en partijen in het veld en burgers veel sterker moeten aanspreken op hun eigen verantwoordelijkheid' (Pijnenburg, Mulder en Schellekens, 2002, p.I). Om de waarden van zorg voor stervenden werkelijk inhoud te geven, kan de overheid niet volstaan met louter instrumentele beheerskaders. De overheid heeft te maken met de praktijk van een samenleving van autonome én van kwetsbare mensen, een samenleving die, om in stand te blijven en zich verder te ontwikkelen, zorg 
nodig heeft. Om in die zorg te kunnen voorzien, om die zorgprocessen op gang te brengen en te houden, is het niet voldoende geldstromen te structureren en beschikbaar te stellen en voorzieningen in het leven te roepen, maar is het ook nodig voeling te houden met de praktijk en de ervaringen, mogelijkheden en spanningen die zich daarin voordoen.

Dit niet alleen door een fijn web van bureaucratische commissies aan het werk te zetten met opdrachten die soms jaren in beslag nemen en die er vooral op gericht zijn structuren te creëren om het zorgaanbod inzichtelijk te maken en om geldstromen in de juiste richting te sturen. De overheid zou daarnaast naar concrete mogelijkheden moeten zoeken om blijvend in gesprek te zijn met de praktijk om in te kunnen spelen op de behoeften die zich steeds nieuw voordoen en om samen met de mensen waarom het gaat een visie te ontwikkelen, beleid te maken en een klimaat te creëren waarbinnen de spanning tussen systeem en leefwereld verminderd en leefbaar wordt.

\subsection{Samenvatting}

Om ethiek in de praktijk inhoud te geven, dienen voorwaarden te worden gecreëerd om communicatie te bevorderen en structurele vormen van communicatief overleg te organiseren. Communicatie is nodig om ethiek in de praktijk vorm te geven. Tegelijk worden de mogelijkheden voor gelijkwaardige communicatie en morele reflectie bedreigd door de spanning tussen systeem en leefwereld.

Kwaliteit van communicatie vraagt van zorgverleners naast professionele kennis en vaardigheden, de bereidheid kwaliteiten te ontwikkelen om op humane en invoelende wijze om te gaan met de emotionele en existentiële vragen die het naderend levenseinde voor de meeste mensen oproept. Ingegaan werd op de beperkingen van de talige communicatie. Niet alles is in woorden uit te drukken. Om uitingen die vreemd zijn aan de eigen kennis en ervaringen te kunnen begrijpen, kan de hermeneutiek behulpzaam zijn. De eigen traditie, de opvattingen over goede zorg en de kennis die men door opleiding en ervaring heeft opgedaan, zijn de horizon van waaruit men vertrekt om het vreemde te ontmoeten. Verwonderd zijn roept vragen op, die het begin kunnen zijn van een dialoog. Ook op de beperkingen van de hermeneutiek is ingegaan.

Vanuit de verschillende niveaus waarbinnen de gezondheidszorg is georganiseerd, werd ingegaan op het belang van communicatie en reflectie voor de werkzaamheid van ethiek in de praktijk en hoe de spanning tussen systeem en leefwereld daarin steeds een rol speelt. Een voorbeeld uit de praktijk diende ter illustratie. Op microniveau riep dat voorbeeld onbehagen op bij zorgverleners. 
Zij wezen erop dat aan communicatie met patiënt, familie en zorgverleners te weinig aandacht was besteed en er geen recht was gedaan aan het principe van respect voor autonomie. Er werd voor gepleit een plaats in te ruimen voor ethische reflectie. Het organiseren van ethisch overleg moet een gelijkwaardige plaats krijgen binnen of naast het bestaande structurele medisch-verpleegkundig overleg over begeleiding en behandeling van patiënten.

Systeem- en leefwereldinvloeden worden op mesoniveau ervaren in de spanning tussen formele regels en de morele situaties die ontstaan in de dagelijkse zorgpraktijk. De zorginstelling biedt regels en protocollen als richtlijnen, tegelijk doen zich in die praktijk steeds nieuwe vragen voor. Ook hier kunnen communicatie en reflectie een belangrijke rol spelen. Ook hier heeft communicatie zijn beperkingen, is niet alles in woorden uit te drukken, en vraagt het signaleren en herkennen van morele dimensies bepaalde kwaliteiten van mensen. Het is de verantwoordelijkheid van zorginstellingen deze kwaliteiten te bevorderen en voorwaarden te creëren voor structureel communicatief overleg over de ethische dimensie van de praktijk en de kwaliteit van de zorg die men voorstaat.

Op macroniveau gaat het om de relatie tussen overheid en zorgpraktijk. Zorg is niet alleen een moreel concept, het heeft ook een politieke betekenis, aldus Tronto (1993, p. r78). De spanning op het macroniveau van zorgverlening is merkbaar in de spanning tussen het organiseren van (zorg)voorzieningen die de overheid goed en wenselijk acht, en de behoeften die de praktijk ervaart. Het gaat om de afstemming tussen voorzieningen die de overheid schept om zorg. organisaties ruimte te bieden de zorg te organiseren en opvattingen van organisaties en praktijk over wat 'goede zorg' is en wat daarvoor nodig is.

De dagelijkse zorgpraktijk is een belangrijke bron voor dit afstemmen, waarbij het niet alleen gaat om het technisch mogelijke, maar vooral ook om het moreel wenselijke. 


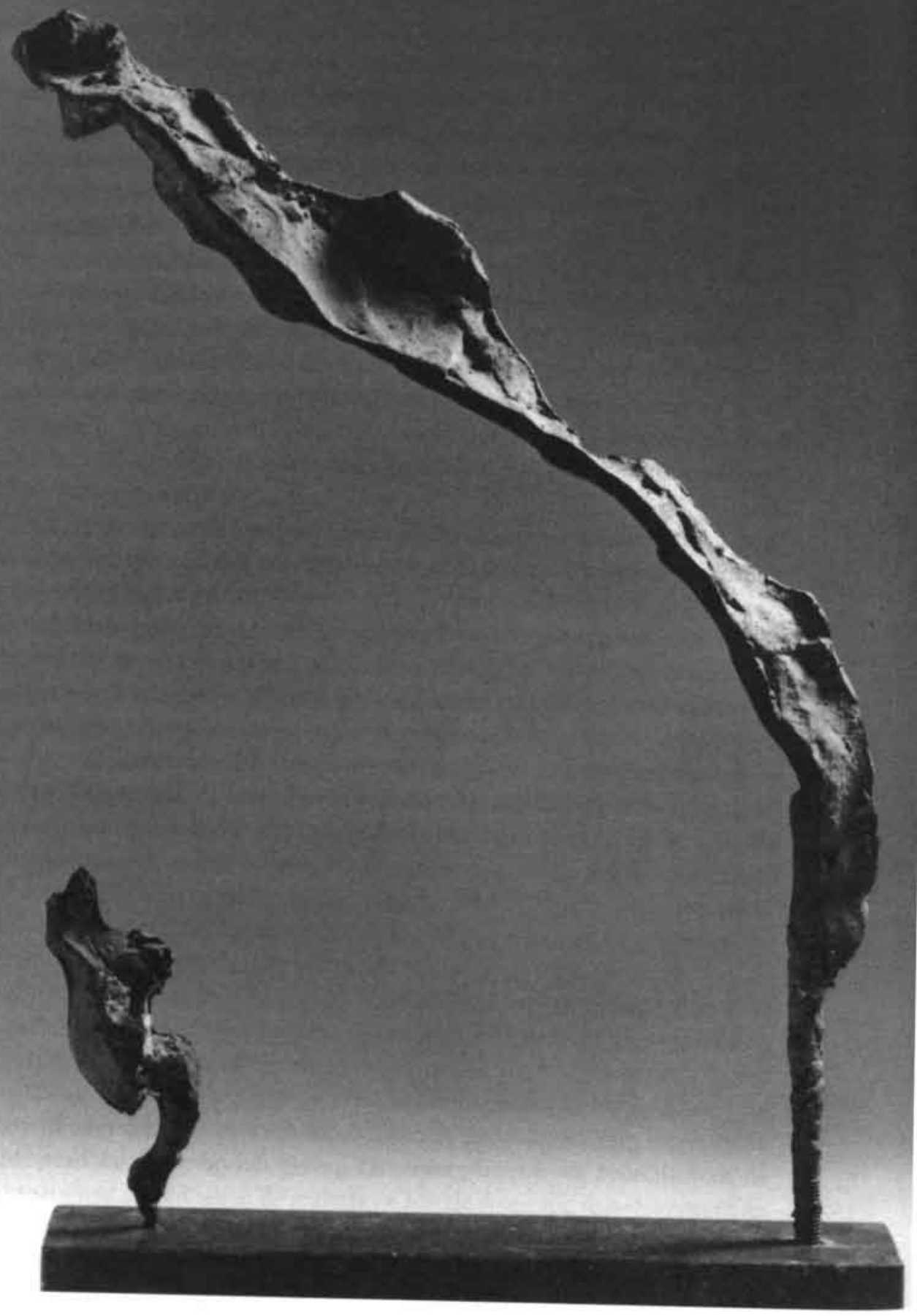


Beter weten

Pas op voor die verlichte geest,

die ieder mens de wet voorleest.

Zijn oor is lam,

zijn oog is blind,

voor wat anders dan zijn waarheid klinkt. 



\section{Responsief onderzoek}

\subsection{Inleiding}

Gezien het doel van het onderzoek en het theoretisch kader dat daarbij centraal staat, werd gekozen voor de responsieve onderzoeksbenadering, een benadering waarbij de inbreng van betrokkenen in de praktijk een belangrijke rol speelt. Doel van het onderzoek is, in dialoog met de praktijk, een bijdrage te leveren aan die praktijk door het beschrijven van ethische probleemsituaties en deze te verhelderen vanuit verschillende invalshoeken. Vanuit maatschappijtheoretisch perspectief worden de problemen in het licht gezet van de spanning tussen systeem en leefwereld. Een spanning, die ook tussen de ethisch theoretische stromingen van de regel-en zorgethiek en vanuit communicatietheoretisch perspectief zijn weerslag vindt: communicatie is nodig om ethiek in praktijk vorm te geven, tegelijk worden mogelijkheden voor gelijkwaardige communicatie en morele reflectie bedreigd door de spanning tussen systeem en leefwereld (theoretisch uitgewerkt in hoofdstuk 3). Gezocht zal worden naar vormen van communicatief overleg en ethische reflectie die een bijdrage leveren aan de kwaliteit van de palliatieve zorg en aan het veiligstellen en verder ontwikkelen van de eigenheid van deze zorg.

In de voorgaande hoofdstukken werden theoretische invalshoeken uiteengezet die een belangrijke rol speelden bij het ontstaan en de verdere ontwikkeling van de palliatieve zorgverlening: maatschappijtheorie, ethiek en grondslagentheorie. Tevens werd ingegaan op de ontstaansgeschiedenis van de palliatieve zorg in Nederland en wat haar doelstellingen zijn. Dit als vertrekpunt voor de onderzoeker om de praktijk te benaderen en met haar in gesprek te raken. Spannende vraag bij deze start is welke vormen van communicatie voor de onderzoeker behulpzaam zijn om de palliatieve werkelijkheid ${ }^{6}$ te leren kennen en inzichten te ontwikkelen. Het praktijkonderzoek was een proces waarin niet

6 Waarbij ik er van uit ga niet van dè palliatieve werkelijkheid te kunnen spreken. Ik bedoel hier vooral de constructies rond palliatieve zorg, waarmee ik in het onderzoek te maken kreeg. 
de methodische procedures, maar het relationele aspect en veelstemmigheid centraal hebben gestaan.

De benadering die aansluit bij de bedoeling een dialoog met de praktijk op gang te brengen, is die naar het ontwerp van zogenoemd leefwereldonderzoek, een vorm van responsief onderzoek, waarbij een belangrijke plaats wordt toegekend aan de inbreng van de betrokkenen in de praktijk (Guba \& Lincoln, 1989; Abma, 1996).

In dit hoofdstuk zal ik allereerst deze benaderingswijze uiteenzetten waarna ik zal ingaan op het plan van aanpak in de praktijk waar het onderzoek plaatsvindt. Dit plan van aanpak is echter geen keurslijf, het werkelijk met elkaar in gesprek gaan, verhoudt zich daar niet mee. Een gesprek aangaan vraagt om een open houding en de bereidheid nieuwe gezichtspunten of mogelijkheden mee te nemen of te overwegen die kunnen bijdragen aan het inzicht in de praktijk van de palliatieve zorg. Aanpassingen die gaande het proces van het onderzoek soms ook nodig bleken. Na de introductie van de methode en het plan van aanpak volgt een beschrijving van de achtereenvolgende stappen en ervaringen die aanleiding waren om af te wijken van de eerste onderzoeksopzet.

\subsection{De responsieve onderzoeksbenadering: uitgangspunten}

Vanuit de optiek van het responsieve discours wordt elke onderzochte praktijk gezien als unieke situatie, waarin personen een centrale rol spelen. Het is een hermeneutische benadering, waarin ervan wordt uitgegaan dat mensen hun werkelijkheid in interactie met elkaar creëren en interpreteren. 'Nature cannot be viewed as it really is (even if one starts with the assumption that there exists a real nature out there to be assessed), but only as seen (constructed) through some value window' ( Guba \& Lincoln, 1989 , p. 65). De responsieve benadering is gericht op het begrijpen van de onderzochte werkelijkheid vanuit een insidersperspectief, zij levert inzicht op over ervaringen en betekenissen die mensen met elkaar in hun praktijk opdoen. Dit door als onderzoeker met die praktijk het gesprek aan te gaan.

Niet de methode staat daarbij op de voorgrond, maar de interactie: 'het verloop (of de stagnatie) van het onderzoek wordt gedicteerd door het onderzochte en niet omgekeerd' (Abma, 1996 p. 89). Kennis wordt gezien als relationeel van aard: 'kennis is gebaseerd op politieke partijdigheid en ontstaat in machtsgevoelige conversaties' (Abma, 1996 p. 106). De inzet van deze benadering is dan ook een samenspraak op gang te brengen waarin actoren vanuit hun verschillende posities, kennis nemen van elkaars standpunten en deze bekritise- 
ren, afzwakken of uitbreiden. Deze samenspraak is er niet op gericht argumenten te vinden om één van de ingebrachte standpunten of om alleen het eigen standpunt te verdedigen en die van anderen te ontkrachten, Doel is de verschillende perspectieven met elkaar te verbinden om in een gezamenlijk proces tot meer inzicht te komen in de praktijk (van de palliatieve zorg), cq. in de mensen die daar werken en verblijven, waarvoor zij staan en wat zij betekenen in de context van die palliatieve zorgpraktijk. Dit relationele proces, dit beter verstaan van elkaar, heeft een doorgaand verloop. Steeds kunnen nieuwe ervaringen worden ingebracht om een nieuw licht op een bepaalde zaak te werpen en het perspectief te verbreden.

Responsiveness is niet alleen of juist een kwaliteit die is verbonden met een bepaald paradigma van waaruit onderzoek wordt geĩnitieerd en georganiseerd. Het is veel meer ook een manier van leven, een nastrevenswaardige morele kwaliteit die nodig is om elkaar en de wereld om ons heen te begrijpen (Schwandt, 200I). De responsieve benadering wil recht doen aan de waarde van pluriformiteit binnen de (post)moderne samenleving en binnen individuele praktijken. Verschillen van opvattingen en de verhalen of uiteenzettingen van specifieke achtergronden en omstandigheden die in individuele situaties een rol speelden, zijn productief in het voortgaand proces van betekenisgeving. Ook de onderzoeker is onderdeel van het proces van kritische reflectie en uiteenzetten van standpunten en ervaringen. Zijn of haar rol is niet die van expert, maar meer van interpretator, en facilitator (Schwandt, 200r; Abma \& Stake, 2001). Kennis en ervaring, waarden en emoties, maar vooral engagement en een open houding zijn belangrijke mogelijkheidsvoorwaarden om dit proces aan te kunnen gaan: 'the rhetoric and the ethic of responsive evaluation is to be open, to come to understand what's going on there, to find more than your initial issues' (Abma \& Stake, 2001, p. 9).

Nadeel van de responsieve benadering, (of constructivistische benadering) wordt vanuit objectivistisch standpunt haar geringe generaliseerbaarheid en subjectivisme genoemd (Guba \& Lincoln, 1989; Abma, 1996). Deze opvattingen hangen samen met het objectivistisch wereldbeeld. Objectivisten gaan ervan uit dat de werkelijkheid gekend kan worden zoals deze 'is', zij benaderen de praktijk als object. Het constructivistisch gezichtspunt gaat uit van relationele kennis van de werkelijkheid en benadert de praktijk als subject(en). In de interactie worden ervaringen geconstrueerd. Het introduceren van allerlei objectivistische strategieën en procedures om authenticiteit en betrouwbaarheid te waarborgen, impliceert volgens Abma (1996, p. 103) 'een miskenning van het interactieve proces van interpretatie.' Zij kunnen afleiden van waar het in essentie over gaat, dat wil zeggen het organiseren van een proces waarin diverse belanghebbenden in de praktijk een inbreng hebben. De erkenning dat 
kennis ontstaat in interactie met anderen, impliceert een ethiek die rekening houdt met verschillende (machts)posities die mensen in interactie met elkaar innemen. Dit vereist van de onderzoeker een kritische houding ten aanzien van de eigen positie en oog voor de positie(s) van waaruit andere betrokkenen deelnemen aan het proces van betekenisverlening. Onderzoek vanuit de responsieve benadering ziet elke zorgpraktijk als individuele en unieke situatie, waaraan deelnemers vanuit verschillende invalshoeken en machtsposities betekenissen, doelen, waarden en normen verlenen.

Wat als betekenisvol uit het onderzoek naar voren komt, kan dienen als klankbord voor andere vergelijkbare praktijken om daar, als 'plaatsvervangende ervaring' mensen te inspireren zich te bezinnen op eigen inzicht en handelen. Herkenning van zichzelf of de eigen praktijk in de beschrijvingen van de onderzoeker, vereist dat die beschrijvingen niet tot afstandelijke taal en algemeenheden beperkt blijven, maar een levensecht beeld schetsen van de context waarin interacties plaatsvonden en van de factoren die in de onderzochte praktijk een belangrijke rol speelden. Deze gedetailleerde beschrijving moet de lezer in staat stellen om te bepalen of die bevindingen ook voor de eigen praktijk waardevol kunnen zijn (Guba \& Lincoln, 1989, p. 260; Wester, 1995, p.,203; Abma, 1996, p.99). Hoewel bevindingen nooit geheel objectief zullen zijn, is het vanuit de responsieve benadering belangrijk dat de lezer in staat wordt gesteld om op basis van eigen ervaringen én die van de onderzoeker, zijn of haar bevindingen te beoordelen in het licht van de eigen praktijk (Abma \& Stake, 200I, p.8). Met andere woorden: niet de onderzoeker bepaalt de geldigheid voor andere praktijken, dat doet de lezer. Op die manier kunnen de constructies van de palliatieve praktijk die het onderzoek oplevert, aanleiding zijn om het gesprek te vervolgen. 'The product of the evaluation is not, in sharp contrast to conventional methodology, a set of conclusions, recommendations, or value judgements, but rather an agenda for negotiation of those claims, concerns and issues that have not been resolved in the hermeneutic dialectic exchanges' (Guba \& Lincoln, 1989, p. 12).

Hoewel de responsivisten bezwaren van generaliseerbaarheid en subjectiviteit zullen weerleggen door te wijzen op de betrekkelijkheid ervan, houden zij vast aan het algemeen aanvaarde uitgangspunt, dat elk onderzoek op gedisciplineerde wijze tot stand moet komen (Abma, 1996). Vastgehouden wordt aan de wetenschappelijkheid van onderzoek en aan een gedisciplineerde werkwijze door de onderzoeker. Waar echter volgens conventionele onderzoeksmethoden het ontwerp en de achtereenvolgende stappen in het onderzoek a priori vastliggen, staat de responsieve benaderingswijze voor openheid, tussentijdse evalu- 
atie en aanpassingen. Methoden en procedures om de validiteit van de bevindingen te waarborgen zijn ondergeschikt aan de meerstemmigheid, de relationele betrokkenheid en de veelzijdigheid van de onderzochte praktijk. Een responsieve houding impliceert een houding van respect en verbondenheid met een praktijk waarin mensen met elkaar samenleven en samenwerken. In interactie met elkaar wordt die praktijk, die werkelijkheid, geconstrueerd en krijgen ervaringen betekenis. Om zicht te kunnen krijgen op dit proces van betekenisgeving is de onderzoeker er op aangewezen deel te nemen aan dit proces van interactie en interpretatie. Procedures om de validiteit van die interpretaties zo veel mogelijk te waarborgen vinden in deze context plaats en zullen, met andere woorden, nooit het gezaghebbend predikaat opleveren zoals in conventioneel onderzoek, maar stof opleveren voor verdere interpretaties in andere praktijken (Abma, 1996, Schwandt, 200I). Inzichten die tijdens het onderzoek ontstaan, nieuwe vragen die door deelnemende actoren naar voren worden gebracht, sturen mede het verloop van het onderzoek. Stake (200I) gebruikt hiervoor de term discovery learning en kent een belangrijke rol toe aan de onderzoeker, als discovery learning teacher (Abma \& Stake, 200r). Stake maakt duidelijk wat hij hiermee bedoeld door discovery learning te contrasteren met didactical learning. De discovery learning teacher baseert zich niet alleen op onderzoeksuitkomsten en feitenkennis, maar zal om een leerproces op gang te brengen ook persoonlijke ervaringen, en prakijkverhalen presenteren. Ervaringen en verhalen van anderen kunnen als plaatsvervangende ervaring dienen voor hen die de praktijk niet kennen of dergelijke ervaringen missen. Didactical learning levert kennis, vertelt wat de waarde is van de uitkomst van een onderzoek, discovery learning brengt een proces op gang waarin de lezer, de leerling, de belanghebbende zelf mee bepaalt en ontdekt wat van waarde is. Guba en \& Lincoln (1989, p. 261) zien het als een van de verantwoordelijkheden van de onderzoeker om een klimaat te creëren waarin dit leren mogelijk wordt: 'It is the evaluator's responsibility in this role to be stage manager for the process, setting the stage in such a way that all stakeholders can learn from one another as well as teach one another (evaluator included).' Dit hermeneutisch dialectisch perspectief is leidraad en uitgangspunt van de onderzoeker in de praktijk en zorgt ervoor dat subjectiviteit van interpretaties in toom wordt gehouden. Een perspectief dat niet tot harde conclusies leidt, maar door haar openheid mensen aanzet om te blijven zoeken naar begrip van onszelf en van de wereld om ons heen en van de betekenis van de ervaringen die onze werkelijkheid kleuren. Een houding, die in responsief onderzoek de waarde van het bij elkaar betrokken zijn verheldert, in een relationele ethiek waarin respect, gelijkwaardigheid en wederkerigheid de toon bepalen. 


\subsection{Planning van activiteiten}

Het onderzoek vond plaats in hospice Rozenheuvel te Rozendaal. Het is een van de eerste hospices die in de pioniersperiode van de jaren negentig de deuren opende. In 1994 werden de eerste patiënten opgenomen. In het jaar waarin het onderzoek plaatsvond, werden er in totaal 197 patiënten behandeld, waarvan 95 opgenomen in het hospice en 103 patiënten thuis, of poliklinisch. De meeste patiënten komen uit de regio na verwijzing door de behandelend arts of op eigen initiatief. Het huis staat vrij in een mooie grote tuin en bosachtige omgeving. Het gaat om kleinschalige zorg met een maximale bezetting van negen bedden. Deze zijn verdeeld over een- en tweepersoonskamers. Zorg wordt verleend door arts(en) en verpleegkundigen, ondersteund door een vaste groep van vrijwilligers. Fysiotherapie, zorg voor de naasten en pastorale zorg maken standaard deel uit van het zorgaanbod, maar ook andere disciplines zijn op aanvraag beschikbaar zoals logopedie, psychologie e.a. Er wordt naar gestreefd een zo huiselijk mogelijke situatie te creëren voor de patiënten en hun familie. Het hospice beschikt over logeerkamers en men maakt gezamenlijk (patiënten, personeel, familie en vrijwilligers) gebruik van de grote keuken annex huiskamer. $\mathrm{Er}$ is ook een stiltecentrum, een ruimte waar mensen zich kunnen terugtrekken om alleen of onder elkaar te zijn. Het management bestaat uit een hoofd medische zorg (medisch directeur), hoofd verpleegkundige zorg, tevens coördinator van de vrijwilligers en een zakelijk directeur, die tevens functioneert als pastoraal werker voor de mensen in het hospice. Pastorale zorg is in het hospice beschikbaar, maar patiënten kunnen ook een beroep blijven doen op geestelijk begeleiders waarmee men in de thuissituatie vertrouwd is. Patiënten die worden opgenomen, worden aangemeld via huisarts, ziekenhuis ofwel door familie. In dat voortraject bezoekt de arts de patiënten om de algehele situatie te beoordelen, eventueel advies te geven en afspraken te maken over eventuele opname. Het hospice heeft een christelijke identiteit, die tot uiting komt in wekelijkse vieringen (op maandag als weekopening), in herdenkingsdiensten waarin overleden patiënten worden herdacht, en in de aandacht voor christelijke feestdagen (Stichting Leger des Heils Welzijns- en Gezondheidszorg, 1999).

Het vereiste enkele voorbereidende stappen om een samenspraak met de praktijk op gang te brengen. Een eerste stap was het benaderen van het management van een palliatieve zorgorganisatie om het onderzoeksplan, de doelstellingen en de methode te bespreken en om tot overeenstemming te komen over deelname aan het onderzoek. Tevens moesten afspraken worden gemaakt over de tijdsduur van het onderzoek, de duur en het doel van de interviews en 
groepsgesprekken, de mogelijke participanten, over de tussentijdse- en eindrapportage, vertrouwelijkheid van informatie, over de werkruimte en andere faciliteiten, alsook over de rol van de onderzoeker in de organisatie gedurende het onderzoek.

Informele contacten met het management en met verschillende zorgverleners in het hospice bestonden al langer. Het eerste formele gesprek over het praktijkdeel van het onderzoek, vond plaats in juni 1999. Doel en opzet van het onderzoek werden besproken met de staf, bestaande uit: de medische- en de algemene directeur en het hoofd van de zorgverlening. Ethiek bleek een onderwerp waar men in het hospice veel belangstelling voor had. Regelmatig werd men in de praktijk geconfronteerd met ethische problemen, waarvoor een oplossing gezocht moest worden. Deze problemen kwamen, naast andere zorgzaken, in het wekelijks Interdisciplinair Zorg Overleg, het IZO, aan de orde. Men had vragen over de kwaliteit van de eigen besluitvorming op ethisch gebied. Als een soort van tegenprestatie voor het meewerken aan het onderzoek, stelde men voor dat de onderzoeker in ieder geval dit wekelijks overleg zou bijwonen om te observeren en terug te rapporteren of en hoe in dat overleg ethische problemen aan de orde komen en wat opvalt met betrekking tot besluitvorming over omgaan of oplossen van deze problemen. Verslag en resultaat hiervan staan in hoofdstuk zes.

Verder werden afspraken gemaakt over introductie-bijeenkomsten. Twee afzonderlijke bijeenkomsten, een voor de professionele zorgverleners en een bijeenkomst voor de vrijwilligers. Dit om het onderzoek te introduceren en uiteen te zetten op welke manier ik vanaf september 1999 in de praktijk aanwezig zou zijn en ook om mensen de gelegenheid te geven vragen te stellen.

De activiteiten waarover afspraken werden gemaakt waren: het bij de start van het onderzoek uitdelen van praktijkverhalen met schriftelijke vragen, het houden van interviews, de selectie van de deelnemers aan de interviews, de plaats, het tijdstip en de duur van de interviews. Tevens werden afspraken gemaakt over te organiseren groepsbijeenkomsten, over het participeren als vrijwilliger in de zorgverlening, en over het bijwonen van het IZO.

De aanwezigheid in de praktijk werd ingevuld door als vrijwilliger mee te werken in de zorgverlening. Vrijwilligers zijn onontbeerlijk in de palliatieve zorg. verlening. $\mathrm{Zij}$ helpen instellingen, organisatie en zorgverleners de kwaliteit van de geleverde zorg te bewaken en mogelijk te verbeteren (Projectgroep Integratie Hospicezorg, 200r). De keuze om als vrijwilliger ingeschakeld te worden gaf mij de mogelijkheid om op een vrij natuurlijke manier deel uit te maken van de praktijk, van het steeds wisselend netwerk van samenwerkende relaties waaruit deze bestaat. Door te investeren in dit netwerk, er mijn bijdrage aan te leveren, werd het voor mij gemakkelijk(er) een vertrouwensrelatie op 
te bouwen met betrokkenen, zowel met de patiënten en naasten, met andere vrijwilligers als met de professionals en management in deze setting.

Het was een rol waarin ik veel ervaring had opgedaan in de periode 1996 . 1998 , in het hospice in Wenen. Deze ervaringen, evenals mijn verpleegkundige achtergrond, kwamen goed van pas. Toegegeven moet overigens worden dat al die ervaringen en eerder opgedane kennis ook nadelig kunnen uitwerken. Niet meer onbevangen tegenover de onderzoekspraktijk staan, kan er ook toe leiden dat je te snel situaties of dingen die gebeuren als vanzelfsprekend plaatst en 'begrijpt'. Het vereist bewustzijn van de eigen positie om het voordeel, het gemak waarmee een plaats in de praktijk wordt ingenomen, niet om te laten slaan naar het nadelig effect ervan door een bepaalde vooringenomenheid. Maar juist open te staan voor nieuwe ervaringen en uit te gaan van de intentie eigen kennis, ervaring en achtergrond productief te laten zijn in het verstaan van anderen.

Drie dagdelen per week zou ik voorlopig in het hospice aanwezig zijn, een dagdeel als vrijwilliger, de andere dagdelen voor het organiseren en houden van interviews en het bijwonen van het IZO. In augustus r999 vonden de introductiebijeenkomsten plaats, de start van het veldwerk was op 9 september van dat jaar.

Tijdens en voorafgaand aan het organiseren van de gesprekken met individuen en groepen uit de betreffende praktijk, was ik participerend aanwezig in het werkveld. Door deel te nemen aan de praktijk die werd bestudeerd, wilde ik enerzijds vertrouwen opbouwen bij de mensen die daarin aanwezig zijn, als ook praktische ervaring opdoen om de organisatie, de verhoudingen, werkzaamheden en betekenissen die in deze specifieke praktijk gangbaar zijn, op praktische wijze te ervaren. Vertrouwen, respect en verantwoordelijkheid zijn belangrijke principes in de omgang met participanten in het licht van het onderzoek (Guba \& Lincoln, 1989; Abma, 1996).

Hoewel oorspronkelijk aan een veldwerkperiode van drie tot zes maanden werd gedacht, nam het gehele onderzoek uiteindelijk, met instemming van de mensen uit de praktijk, een heel jaar in beslag. Hiervoor was ik in de beginperiode drie dagdelen en vanaf maart 2000 één dagdeel per week in het hospice aanwezig.

\subsection{Introductiebijeenkomsten}

Op 3 en ro augustus 1999 vonden de introductie-bijeenkomsten plaats, één voor professionals en aansluitend één voor de vrijwilligers in het hospice. Doel ervan was om kennis te maken met elkaar en om het doel en de werkwijze van 
het onderzoek uiteen te zetten en om in te gaan op eventuele wensen of vragen. In r998 was door het hospice al eerder medewerking verleend aan onderzoek op gebied van ethiek. Poppema en Ziedses verrichtten onderzoek naar morele problemen van verpleegkundigen met de autonomie van de patiënt in de palliatieve zorg. Het onderzoek, Deskundigheid en autonomie, was tevens hun afstudeerproject aan de Christelijke Hogeschool te Ede. In de introductiebijeenkomst heb ik duidelijk gemaakt waar dit nieuw te starten onderzoek op eerder onderzoek aansloot en waar het anders was en verder ging. Aansluiting vond ik in de aanbevelingen van de onderzoekers: het structureel en systematisch bespreekbaar maken van morele problemen. Bijvoorbeeld door het organiseren van teambesprekingen waarin ethische vragen of problemen en de omgang daarmee centraal staan. In tegenstelling tot wat Poppema en Ziedses in hun onderzoek deden, beperkt mijn onderzoek zich niet tot dilemma's rond autonomie versus deskundigheid. Bovendien richt ik me niet alleen op verpleegkundigen. Ook andere disciplines, andere bij de zorg betrokkenen, wordt gevraagd deel te nemen aan het onderzoek. Ik streef ernaar zoveel mogelijk perspectieven, zoveel mogelijk belanghebbenden bij het onderzoek te betrekken.

\subsection{Participatie in de praktijk}

Door bekendheid met het werkveld en eerdere ervaringen als vrijwilliger in de palliatieve zorg verliep het begin van het onderzoek, en het participerend aanwezig zijn in de praktijk zonder problemen. De vrijwilligers en professionals vormen een hechte groep, die al lang met elkaar samenwerkt.

Men stond positief en geïnteresseerd tegenover het doel van het onderzoek. Het was ook niet moeilijk om afspraken te maken voor de interviews. Ethiek stond hoog op de agenda, men was van plan om regelmatig een ethisch beraad te organiseren. Men wilde ook in het wekelijks interdisciplinair zorgoverleg, het IZO, meer aandacht voor ethische uitgangspunten en problemen. Dit overleg zou ik gaan bijwonen, om te observeren hoe men daarin slaagde.

Doel van het vrijwilliger zijn was, van binnen uit, de hospice-werkelijkheid te ervaren en wel met het oog op de doelstelling van het onderzoek. Het was niet zo dat ik me tijdens het werk steeds volledig bewust was van deze doelstelling. Ik kreeg een indruk van de sfeer, het klimaat waarin mensen samenwerken, en waarvan patiënten deel uitmaken. Ik had het gevoel welkom te zijn en ook, dat mensen iets (positiefs) van mij verwachtten. Er waren mensen, die me ervaringen toevertrouwden, omdat 'ethiek' mijn onderwerp was. Die verhalen, heel indringend soms, kwamen spontaan, ik realiseerde me vaak pas later waarom 
mij zo'n voorval werd verteld: het is jouw onderwerp, ethiek, doe jij er iets aan. De vertrouwelijkheid en de geladenheid van de ervaringen die men niet in een gezamenlijk overleg durfte aan te kaarten, brachten mij ook steeds een beetje in verwarring. Enerzijds werd ik benaderd als vriend en medestander, tegelijk voelde ik me aangesproken als 'deskundige', als onderzoeker met ethiek als onderwerp. Als onderzoeker was ik geïnteresseerd en op zoek naar moeilijke situiaties, als vriend breng je wat je in vertrouwen verteld wordt niet zomaar naar buiten.

Een voorbeeld van zo'n ervaring ging over het belang van een dag- en nachtritme en werd verteld door een vrijwilliger:

Het gaat om een nog vrij jonge man, die ernstig ziek is en niet lang meer zal leven. In de rolstoel wordt hij regelmatig naar de huiskamer of naar de serre gebracht. In de serre mag gerookt worden. Eigenlijk is hij vaak te moe om in de rolstoel te zitten, kan niet goed meer rechtop blijven en wil dan graag weer in bed gebracht worden. Joke, een vrijwillige hulpverlener, vertelde mij hoe zij deze patiënt op een ochtend aantrof. Hij was uitgeput en kon met moeite de woorden vinden om te zeggen 'ik wil naar bed'. Joke riep de hulp van een verpleegkundige in om de man naar bed te brengen. Echter deze vertelde haar dat dat niet de bedoeling was. De patiēnt moest het dag en nachtritme weer te pakken krijgen en daarom was het beter dat hij nog wat in de rolstoel bleef zitten. Joke 'klapte dicht' en was er erg van overstuur dat een patiënt zo hulpeloos moest blijven zitten terwijl hij niet meer kon. Even later is de patiënt toch naar bed gebracht, waar hij enkele uren later overleed.

Op mijn vraag waarom iemand zo'n ervaring niet in het IZO of in een ander overleg op de agenda zet, zegt men: 'Ik klap dan dicht'. Mensen voelen zich soms machteloos, missen blijkbaar het gevoel van veiligheid en het vertrouwen of de woorden om datgene waar men tegenaan loopt, kritisch tegen het licht te houden in samenspraak met anderen. Conflictvermijding kan verband houden met de angst voor onvoorspelbare en oncontroleerbare emotionele uitingen (Abma, 2000, p. 210). Ook tussen professionals onderling komt het nogal eens voor dat kritische opmerkingen niet op prijs worden gesteld en men deze voor zich houdt. Dit defensief vermijdingsgedrag in professionele organisaties is gebaseerd op de ongeschreven regel 'als jij geen kritiek hebt op mij, kritiseer ik jou ook niet' (Moen en Abma, 1992). Als er toch kritiek wordt geuit, is men niet in staat dit in breder perspectief te plaatsen, maar reageert men onmiddelijk defensief. Dit leidt er dan weer gemakkelijk toe dat situaties escaleren, dat een zondebok wordt aangewezen en er geen oplossing wordt gevonden. Dit was ook de angst van Joke. Wat in de situatie van Joke wellicht meespeelde is 
de relatie professional - vrijwilliger, waarin ongemerkt machtsverhoudingen een rol spelen. Dit soort situaties maken duidelijk dat de communicatie onder druk staat. De rationaliteit van het systeem creëert een onveilig klimaat voor uitspraken die een appèl doen op emotionele, existentiële en morele dimensies van het werk. In een open en responsief klimaat zou het vertellen van deze persoonlijke ervaring niet onmiddelijk leiden tot defensief gedrag, maar begrip oproepen voor het effect dat het teweeg bracht bij zowel de patiënt als bij de zorgverlener. Dit zou een aanleiding kunnen zijn voor een gesprek om recht te doen aan die ervaring en gezamenlijk te zoeken naar meer inzicht over hoe om te gaan met situaties waarin fysieke en geestelijke dimensies van zorg onevenredig in het licht staan.

\subsection{Fasen in het onderzoek}

\subsubsection{Praktijkverhalen}

Uitgangspunt van het onderzoek was een dialoog met de praktijk op gang te brengen om niet als buitenstaander, maar zo veel mogelijk van binnenuit de praktijk te leren kennen. Om dat gesprek op gang te brengen, heb ik bij het begin van het onderzoek de beschrijving van vier verschillende praktijksituaties in de palliatieve zorg aan respondenten voorgelegd. In elk van de vier gevallen gaat het om een moeilijke situatie. De praktijkvoorbeelden waren gebaseerd op reële situaties die ik in de periode $1996-1998$ het St. Raphaël Hospitz meemaakte. Zij werden voorgelegd aan respondenten uit de verschillende disciplines. Dit om zoveel mogelijk perspectieven een kans te geven te reageren. In totaal werden tien respondenten benaderd, elk kreeg twee van de vier praktijkverhalen voorgelegd met begeleidende brief en korte vragenlijst. Hierin werd gevraagd naar vergelijkbare ervaringen en hoe zij er in de eigen situaties mee zouden omgaan of omgegaan zijn en wat naar hun mening zowel voor de hulpverlener(s) als voor de patiënten die in de voorbeelden worden genoemd, eigenlijk het probleem is waarom het gaat.

Het werken met verhalen uit de praktijk biedt respondenten mogelijkheden zich te herkennen, of juist niet, en de eigen opvattingen en waardenoordelen te spiegelen aan die welke in de verhalen naar voren komen. Of om hun eigen verhaal hun eigen ervaringen met een dergelijke situatie, te vertellen. Deze inzichten zijn gebaseerd op de narratieve benadering in de filosofie. Volgens deze benadering presenteren mensen zichzelf door het vertellen van hun verhaal en steunen zij daarbij op de verhalen van anderen (Widdershoven, 
$2000 b)$. Het vertellen van verhalen is één van de mogelijkheden van mensen om moeilijke of juist prachtige ervaringen te presenteren en deze onder de aandacht te brengen van anderen, die deze ervaringen niet hebben of die dergelijke ervaringen op een andere manier beleven (Abma, 2001). Verhalen brengen gemakkelijk een gesprek op gang en nodigen uit tot (kritische) reacties. 'One can also understand stories as social constructions of ' $a$ ' reality that we can never truly represent' (ibid, p. 274).

Het vertellen van verhalen leert mensen de dingen die hen overkomen of waar men mee te maken heeft, zoals ziekte en verlieservaringen, maar ook ervaringen van schoonheid en liefde, te integreren in hun leven en daar vorm en betekenis aan te geven. Een inzicht dat verwijst naar een relationeel mensbeeld en breed autonomiebegrip (Manschot en Verkerk, 1997; zie ook hoofdstuk 2). Geen opvatting van de autonome mens die beschermd moet worden tegen inmenging, maar een opvatting waarin de mens verschijnt als iemand die onafhankelijk is omdat hij in staat is de dingen die gebeuren te plaatsen en in zijn leven te integreren (Widdershoven, 2ooob).

\subsubsection{Interviews}

Om een beeld te krijgen van de beleefde en gewenste werkelijkheid van betrokkenen bij de palliatieve zorg, werden interviews georganiseerd. Er werden zeventien mensen geïnterviewd: vier proefinterviews en dertien interviews in het hospice waar het veldwerk plaatsvond. Twee proefinterviews vonden plaats in een hospice met een pastoraal werker en een met een ziekenverzorgende, het derde interview vond thuis plaats met een vrijwilliger, werkzaam in een hospice en het vierde proefinterview had ik op een palliatieve afdeling van een ziekenhuis met een verpleegkundig coördinator. De proefinterviews organiseerde ik om zowel het interviewschema als de opnameapparatuur te testen en om na te gaan of de praktijkverhalen die ik aan het begin van het veldwerk aan respondenten zou voorleggen, herkenning opriepen. Ook de proefinterviews werden bij het onderzoek betrokken. De overige dertien interviews werden gehouden in het hospice van het onderzoek, met drie verpleegkundigen, een vrijwilliger, twee artsen, een fysiotherapeut en een patiënte, een receptionist, een dochter van een patiënt, een pastoraal werker, een medewerkster huishoudelijke dienst, een begeleidster (verpleegkundige) van naasten. De selectie van respondenten was erop gericht een zo groot mogelijk variatie van perspectieven te organiseren, een zogenoemde dwarsdoorsnede te creëren van opvattingen van mensen die zijn betrokken bij de zorg in een hospice voor palliatieve zorg. De deelnemers werden geselecteerd in samenspraak met het manage- 
ment van het hospice, waarbij beschikbaarheid volgens de dienstroosters een belangrijk criterium was. De interviews werden veelal tijdens werktijd van respondenten gehouden, in sommige gevallen werd een afspraak gemaakt buiten de werktijd. In overeenstemming met de responsieve benadering werden geïnterviewden door het stellen van open vragen zoveel mogelijk zelf aan het woord gelaten. Niet de onderzoeker droeg nu praktijkvoorbeelden aan, geïnterviewden werden aangemoedigd hun eigen verhaal te vertellen.

Het ging om semi-gestructeerde diepte-interviews. Hoewel het erom ging de respondenten zoveel mogelijk ruimte te geven, werd het interview min of meer gestuurd door de aard van de vragen die op hun beurt weer in relatie stonden met het doel van het onderzoek. Met name werd doorgevraagd naar voor respondenten moeilijke situaties, en op voor hen negatieve en/of juist positieve ervaringen. De gesprekken werden op een cassetteband opgenomen en zo mogelijk dezelfde dag volledig uitgewerkt. De transcripten van de interviews, werden aan de gesprekspartners voorgelegd ter verificatie. Onduidelijkheden of onjuiste weergaven konden aan de hand van de reacties worden bijgesteld. Een van de interviews (tweede arts) was niet bruikbaar, kon niet worden uitgetypt, omdat de kwaliteit van het geluid onvoldoende was. De interviews namen ongeveer een uur in beslag. De thema's waarlangs de interviews werden gestructureerd waren: ervaringen en opvattingen van palliatieve zorg, ethische uitgangspunten, communicatie en opvattingen over kwaliteit: wat is goede palliatieve zorg, wat is goed sterven. De verschillende uit de interviews te destilleren gezichtspunten, onderwerpen of problemen, als ook de ervaringen opgedaan tijdens de participatie in de zorgpraktijk, moesten materiaal opleveren om in groepsgesprekken aan de orde te stellen. De keuze van het interview als instrument om te horen wat de mensen in de praktijk ervaren als ethische vragen en problemen, levert een 'veelstemmig' beeld op (Abma, 1996 p. 126). Voor de onderzoeker de taak deze veelstemmigheid te vertolken en met de verschillende belanghebbenden samenspraak en overleg aan te gaan over de onderwerpen en problemen die in de interviews naar voren kwamen. Bedoeling van deze samenspraak is niet alleen tot consensus en wederzijds begrip te komen, maar ook om wederzijdse afhankelijkheden en belangen te onderkennen, deze te begrijpen en zo mogelijk manieren te vinden met die spanning om te gaan.

\subsubsection{Selectie van verhalen en opvattingen}

Onderzoeksgegevens analyseren vanuit onderzoeksvragen en hypothesen speelt een ondergeschikte rol in responsief onderzoek. Het gaat er niet om 
ideeën en theorieën te toetsen aan de onderzochte praktijk, maar veel meer om in de praktijk en in de verhalen van respondenten die concepten te beluisteren die het fundament en de dynamiek van die specifieke praktijk onderbouwen en voeden. Dit vraagt van de onderzoeker de eigen opvattingen tijdelijk tussen haakjes te plaatsen (Abma, 1996, p.92). Het verhaal van het onderzoek, hoe het verliep en wat als betekenisvol naar voren kwam, moet zo verteld (opgeschreven) worden, dat de lezer in staat is dit proces enigszins mee te beleven om te beoordelen of wat geldig is in de onderzoekspraktijk ook geldig is in andere praktijken. En om het mogelijk te maken het gesprek in andere contexten voort te zetten. 'Directe ervaring is een efficiënte, omvattende en bevredigende manier om begrip te creëren, maar dikwijls onmogelijk om te realiseren. Plaatsvervangende ervaringen fungeren als een substituut voor de directe ervaring' (Abma, 1996, p.65).

Om de eigen opvattingen naar de achtergrond te kunnen schuiven is het belangrijk te weten wat de eigen positie is, van welke ideeën en veronderstellingen ik als onderzoeker eigenlijk het gesprek met de praktijk inging. Voor een belangrijk deel werd de bril waarmee ik naar de zorgpraktijk keek, gekleurd door ervaringen en betrokkenheid. Ervaringen zoals die ik beschreef in de inleiding over het levenseinde van een vriend, maar ook de aantrekkingskracht die de zorg steeds op mij had en waardoor ik er ooit zelf toe kwam verpleegkundige te worden. Ook hoe ik met die verpleegkundige praktijk gestopt ben om thuis voor mijn kinderen te zorgen en er na een lange periode weer 'instapte' om een wereld van verschil te ontdekken. En natuurlijk de recentere praktijkervaringen in het hospice in Wenen. Eigenlijk heel veel levenservaringen voedden mijn gedachten en opvattingen over de palliatieve zorgverlening. Een veelheid van ervaringen die samen een belangrijke drijfveer vormden voor mijn betrokkenheid bij de palliatieve zorg en voor de start van het onderzoek. Tegelijk ben ik me er steeds van bewust dat die ervaringen niet dé werkelijkheid van dé zorgverlening uitmaken, maar slechts van een door mij beleefd deel ervan. Toch is het tussen haakjes zetten van dat eigen perspectief niet eenvoudig en ik denk ook niet dat ik daarin helemaal in ben geslaagd. Veel meer voel ik me er vertrouwd mee te proberen met een zo open mogelijke houding mensen tegemoet te treden, in gesprek te gaan en te luisteren. Niet alleen in de gesprekken, maar vooral door aanwezigheid en aandacht wordt een sfeer en worden gevoelens (her)kenbaar. Interviews leveren meer op dan een aantal data met betrekking tot het doel van het onderzoek. Hoewel de interviews enigszins voorgestructureerd waren, was deze structuur niet bindend, er was veel ruimte voor de eigen inbreng van respondenten met name om aan de hand van eigen ervaringen opvattingen te verduidelijken. Het uitwerken en rustig doorlezen van de interviews leverde dan ook meer informatie op dan 
wanneer ik louter vanuit de aangebrachte structuur de gesprekken was aangegaan. Omdat de interviews mede waren bedoeld om te zoeken naar betekenisvolle onderwerpen om in multidisciplinaire groepsgesprekken uit te diepen, heb ik een aantal onderwerpen en uitspraken uit die gesprekken voor dat doel geselecteerd. De thema's waren communicatie, moeilijke zorgsituaties en opvattingen die respondenten in de interviews uitten over goede zorg, over ethiek en over autonomie. In de groepsgesprekken zou het gesprek verder gaan, zouden nieuwe verhalen en mogelijk nieuwe vragen opklinken.

\subsubsection{Groepsgesprekken}

Een volgende door mij voorgenomen stap in het onderzoeksproces was het organiseren van groepsgesprekken. Respondenten uit de verschillende disciplines werden hiervoor schriftelijk uitgenodigd, met uitleg van het doel van de bijeenkomst, en de duur, tijd en plaats ervan. Doel van de groepsbijeenkomsten was om de verschillende onderwerpen en moeilijke situaties, genoemd in de interviews, met elkaar te verbinden en te zoeken naar breed gedragen opvattingen over de ingebrachte onderwerpen of problemen. Consensus wordt door Guba en Lincoln (1989), als uiteindelijk doel van deze gesprekken genoemd. Hoewel dat ook mijn streven was, ging ik er bij het plannen van de groepsbijeenkomsten van uit, dat ook wanneer gesprekken niet tot volledig gedeelde standpunten leiden, deze zinvol zijn (Abma, 1996). Het delen van ervaringen en standpunten, ook als deze afwijkend zijn en/of blijven, kan een meerwaarde hebben, wederzijds respect en begrip voor verschillen van opvattingen opleveren.

Er zijn op bepaalde gebieden wellicht meerdere wegen mogelijk met betrekking tot kwaliteit van zorg en kwaliteit van omgaan met ethische dilemma's. Dat verschillen mogelijk zijn kan teken zijn van respect voor elkaar in een klimaat waarin het belang van het delen van ervaringen belangrijker is dan overeenstemming over de betekenis ervan. Ook vanuit het perspectief van het hermeneutisch proces, als steeds doorgaande cirkel van verstaan, is het mogelijk verschillen in opvattingen te accepteren als voorlopige uitkomst in een communicatieproces (Gadamer, 1986; Widdershoven, 2000b).

De groepsbijeenkomsten, ook wel leer-platforms genoemd, vonden plaats begin november: één bijeenkomst met professionals, mannen en vrouwen van verschillende disciplines en één met vrijwilligers (vrouwen). De bijeenkomsten werden op cassetteband opgenomen en volledig uitgetypt. De bijeenkomsten leverden echter niet de dialogen, de samenspraak op, die ik me ervan had voorgesteld. Het effect van ingebrachte onderwerpen en problemen leidde tot relativerende opmerkingen, maar niet tot herkenning en samenspraak, zoals 
de bedoeling was. Een inschattingsfout wellicht, van mijn vermogen tot het begeleiden van dit soort bijeenkomsten. Mogelijk spraken de voorbeelden die ik gebruikte niet voldoende aan, deed de presentatie van opvattingen onvoldoende recht aan de intentie waarmee ze in de interviews waren geuit, of waren deze niet consistent met wat er in de praktijk gebeurt, waardoor zij in de groep niet herkend of relevant werden gevonden. Ik besloot mijn onderzoeksactiviteiten voorlopig te beperken en te volharden in participerende observatie en tegelijk uit te kijken naar manieren om, met gebruik van het verzamelde materiaal, de praktijk verder te laten spreken. Een andere gelegenheid deed zich half oktober voor. Ik was aanwezig bij een door het management georganiseerd ethisch beraad rond een probleem bij de zorg voor een patiënt waarbij verscheidene verpleegkundigen en een arts betrokken waren geweest. Een probleem dat veel emoties had losgemaakt en existentiële en ethische vragen had opgeroepen bij de betrokken zorgverleners. Tijdens dit beraad werd mij gevraagd te participeren in het overleg. Betrokken zorgverleners spraken de wens uit gezamenlijk beleid te ontwikkelen voor dergelijke noodsituaties, die zich in de toekomst opnieuw kunnen voordoen. Aan mij werd gevraagd deze bijeenkomsten verder te organiseren en te begeleiden. Vervolgbijeenkomsten vonden plaats in december 1999, in april en in september 2000. In januari 2001 vond een eerste evaluatie van het afgesproken beleid plaats.

Door deze ontwikkeling kreeg ik alsnog de gelegenheid platforms te organiseren, nu rond een thema dat op initiatief van en door zorgverleners zelf was ingebracht. De door de zorgverleners gezamenlijk ingebrachte casus werd in vier opeenvolgende bijeenkomsten met professionele zorgverleners uit de verschillende disciplines besproken om beleid te ontwikkelen ten aanzien de ingebrachte problematiek. Het werd een volgende stap in het onderzoek. Deze bijeenkomsten werden niet op band opgenomen, wel heb ik samenvattingen gemaakt, die aan de respondenten werden voorgelegd voor commentaar. Elke bijeenkomst begon met een gezamenlijke terugblik alvorens het interactieproces te vervolgen.

De bijeenkomsten over dit ethisch kwaliteitsbeleid, startten in december 1999 en werden in september 2000 afgerond met beleid en afspraken voor de toekomst. In hoofdstuk zeven een gedetailleerd verslag van dit proces en de ingebrachte casus.

\subsection{Validiteits procedures}

Hoewel erkend wordt dat de onderzoeker altijd en onvermijdelijk effect zal hebben op de praktijk die hij of zij bestudeert en omgekeerd, zijn er, zonder af 
te doen aan relationele betrokkenheid en veelstemmigheid, een aantal strategieën en procedures beschikbaar om die subjectiviteit zoveel mogelijk te beperken (Wester, 1995; Abma, 1996, p.102; Schwandt, 2001).

De member check vormt een belangrijke procedure voor de onderzoeker om na te gaan of zijn of haar interpretaties valide en herkenbaar zijn in de ogen van de respondenten. Het verschaft respondenten de mogelijkheid onjuistheden in die interpretaties aan te wijzen en deze aan te passen en mogelijk additionele informatie te verschaffen. Tijdens de interviews heb ik daarvan gebruik gemaakt door stukjes van het gesprek samen te vatten en te checken of ik het goed begrepen had. De member check creëert ruimte voor andere interpretaties waardoor recht kan worden gedaan aan de meervoudigheid van betekenisverlening en interpretatie (Abma, I996, p. 95). Zo bieden ook groepsbijeenkomsten mogelijkheden op interactieve wijze na te gaan of bevindingen van eerdere observaties en interacties overeenstemmen met die van de respondenten. Het proces van beleidsontwikkeling is een voorbeeld daarvan, evenals de tussentijdse- en eindevaluaties met het management met betrekking tot het IZOoverleg.

Triangulatie is een andere procedure om de betrouwbaarheid, reikwijdte en veelstemmigheid van de bevindingen te vergroten. Dit door het gebruik van meerdere bronnen en instrumenten om gegevens te verzamelen en het gebruik van meerdere theoretische kaders en perspectieven om als waarnemer(s) naar de data te kijken. Triangulatie biedt expliciet ruimte voor meerstemmigheid, en het idee van meervoudige werkelijkheden (Abma, 1996, p.95). Door de verschillende manieren van dataverzameling tijdens het veldwerk kwam dit tot $z^{\prime} n$ recht. Maar ook door verschillende theoretische kaders bij het onderzoek te betrekken. Een proces dat er in de loop van het onderzoek toe leidde dat er naast het communicatief en ethisch-theoretisch kader een maatschappijtheoretische invalshoek bij het onderzoeksperspectief werd betrokken.

Het hermeneutisch proces zelf beschouwen Guba en Lincoln (1989) ook als vorm van validering. Het betrekken van veel belanghebbenden die vanuit verschillende positie deel uitmaken van de onderzoekspraktijk voorkomt dat blinde vlekken of eenzijdigheid ontstaat. Tijdens het onderzoek heb ik verscheidene hulpverleners, vrijwilligers en leidinggevenden betrokken in het proces. Minder sterk is dat slechts één patiënt en één familielid werd geinterviewd. Patiënten en familie werden niet betrokken bij het vervolg van het onderzoek zoals het ontwikkelen van sedatiebeleid.

Langdurige betrokkenheid maakt het mogelijk vertrouwd te raken met een praktijk, een beter inzicht te ontwikkelen voor wat gewoon en ongewoon is; het biedt ook mogelijkheden om weer voldoende afstand te nemen om eenzijdige 
identificatie te voorkomen (Guba \& Lincoln, 1989; Abma, 1996). Gedurende het praktijkonderzoek was ik wekelijks op vaste dagen aanwezig voor verschillende onderzoeksactiviteiten: in de hoedanigheid van vrijwilliger, om interviews af te nemen, voor groepsbijeenkomsten en in verband met het IZO. Die periode nam een jaar in beslag van september 1999 tot september 2000.

Referentielle adequaatheid: het verzamelen van een verscheidenheid aan materiaal als betekenisvolle achtergrond voor analyse en interpretatie. In de loop van het onderzoek heb ik veel materiaal verzameld, meer dan ik kon gebruiken. Naast transcripten van interviews en groepsbijeenkomsten, zijn er verslagen van de bijeenkomsten waarin beleid werd ontwikkeld, verslagen en evaluaties van IZO-bijeenkomsten, verslagen van het ethisch beraad, aantekeningen en tussentijdse rapportages over de voortgang van het onderzoek, de praktijkverhalen en de reacties erop, en verslagen van gesprekken over de voortgang, interpretatie en verslaglegging met mijn begeleiders.

Peerdebriefing 'draagt bij aan geloofwaardigheid door vakgenoten, die buiten het onderzoeksveld staan te vragen om als het ware over de schouder van de onderzoeker mee te kijken naar gegevens, interpretaties en ontwikkelde ontwerpen en te luisteren naar de ideeën en zorgen van de onderzoeker'(Abma, 1996, p.96). Hierin hebben mijn begeleiders een grote rol gespeeld. Gesprekken met hen hebben geholpen wat meer afstand te nemen van mijn ervaringen in hospice Rozenheuvel, waardoor over-identificatie met betrokkenen werd voorkomen. Gesprekken die mij ook meer openstelden voor de waarde van de regelethiek waardoor deze meer in balans kwam met mijn sympathie voor de zorgethiek.

\subsection{Samenvatting}

Voor het onderzoek van deze palliatieve zorgpraktijk werd gekozen voor de responsieve benaderingswijze. Een methode waarin de praktijk deelneemt aan de dialoog over het inzichtelijk maken van ethische problemen en de spanningen die men tegenkomt in de dagelijkse zorgpraktijk. Er is veel ruimte voor de stem van die praktijk, niet de methode maar de ervaringen van de onderzochten staan centraal. Bij het plannen van activiteiten was het belangrijk open te blijven staan voor verandering en nieuwe wendingen in het onderzoek. Om het effect van subjectiviteit zoveel mogelijk te beperken werd gebruik gemaakt van een aantal validiteitsprocedures als member check, triangulatie, langdurige betrokkenheid, referentiële adequaatheid en peerdebreefing.

$\mathrm{Na}$ de introductie van doel en werkwijze in de praktijk werden praktijkverhalen uitgereikt en om reacties gevraagd. Het ging om realistische situaties die vra- 
gen opleverden. Dit als opening voor gesprekken later. Op de dagen dat ik aanwezig was in het hospice nam ik als 'vrijwilliger' deel aan de zorg, op die wijze kreeg ik de gelegenheid om de praktijk van binnenuit te leren kennen, er vertrouwd mee te raken. Om de interviews te organiseren werden afspraken gemaakt met zorgverleners en management. De interviews vonden zoveel mogelijk plaats op dagen dat zorgverleners dienst hadden, soms ook kwam men er speciaal voor naar het hospice. Ook de eerder gehouden proefinterviews werden bij het onderzoek betrokken. Om zo veel mogelijk perspectieven toe te laten, werden mensen uit verschillende disciplines die op een of andere wijze bij de zorg betrokken waren, benaderd. Ook werden een patiënt en een familielid geïnterviewd. Het organiseren van groepsgesprekken was een volgende stap in het onderzoeksproces. Aan de hand van een aantal onderwerpen en verhalen uit de interviews werden gespreksthema's geselecteerd. Deze thema's waren communicatie, moeilijke zorgsituaties, opvattingen van goede zorg, ethiek en autonomie. De bijeenkomsten, één voor professionals en één voor vrijwillige zorgverleners, leverden niet de samenspraak op waarvoor ze waren bedoeld. Besloten werd om in plaats van de geplande groepsbijeenkomsten in te gaan op het verzoek van zorgverleners een proces van beleidsontwikkeling te begeleiden naar aanleiding van een ethisch moeilijke situatie die zich eerder had voorgedaan. Tijdens de gehele periode van het veldonderzoek werden de wekelijkse IZO-bijeenkomsten bijgewoond om te observeren hoe ethiek daarin een plaats heeft en hoe ethische besluitvorming tot stand komt. 


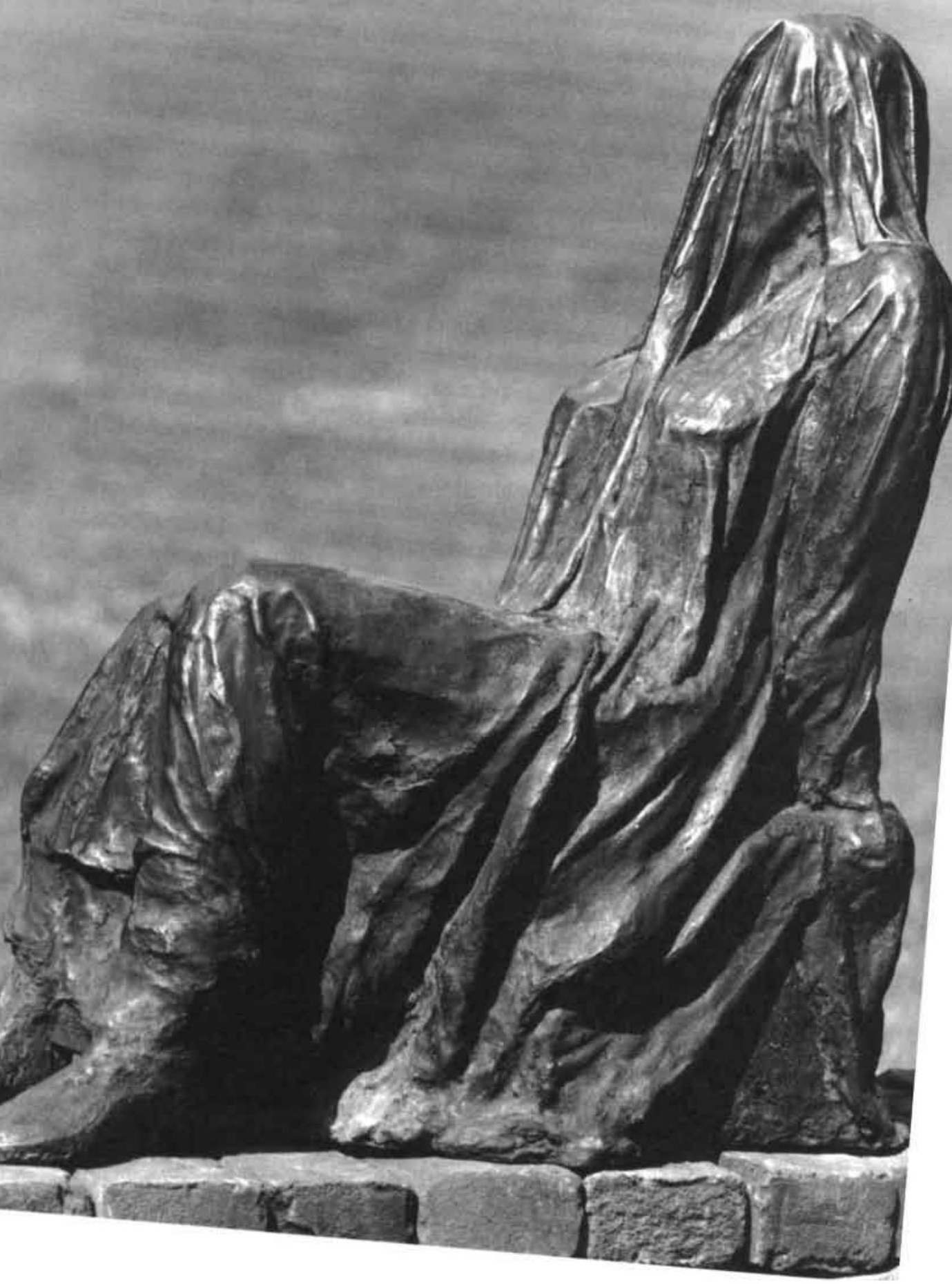


De dagen zijn als zand, nat van de regen, er kleven nog wat korrels aan je hand, ze lijken zwaar te wegen.

Het zandkasteel verwatert en verdwijnt nu snel het tij verrast de gasten in hun spel.

We keren onze zakken om op bed, je hand is net te zwak en hecht aan wat nog rest.

Voorzichtig, één voor één geef je de korrels prijs, je rijgt ze tot een trein aaneen en gaat op reis, alleen. 



\section{Ethiek als bron, of ethiek onder druk?}

\subsection{Inleiding}

Zoals ethiek is verbonden met morele normen, zo vormen ook theorie en praktijk van zorgverlening een levend geheel. Morele normen bieden richtlijnen voor het handelen, tegelijk vereist de ethiek een grondhouding van bereidheid om morele uitgangspunten en ervaringen steeds te spiegelen aan de praktijk. De morele opvattingen over kwaliteit van zorgverlenen en omgang met elkaar en met de eindigheid van de mens, waren de oorsprong en inspiratie van pioniers die in het begin van de jaren negentig initiatieven namen voor palliatieve zorgvoorzieningen en daarmee een nieuwe beweging op gang brachten rond de zorg voor stervenden.

Om zicht te krijgen op ethische probleemsituaties in de praktijk van de palliatieve zorg was het dan ook niet voldoende ethische- en maatschappijtheoretische kaders en ontwikkelingen te bestuderen, maar moest een gesprek met de praktijk worden aangegaan. Het veldonderzoek dat in september 1999 begon had tot doel een dialoog op gang te brengen en over een langere periode deel uit te maken van de onderzochte praktijk. Door participerende observatie, praktijkverhalen en interviews, werd de praktijk inzichtelijk gemaakt.

Dit hoofdstuk gaat over ethische opvattingen in de praktijk. De uitkomsten van de interviews en de reacties op de aangereikte praktijkvoorbeelden maken duidelijk welke ethische opvattingen belangrijk zijn voor de betrokkenen in de praktijk, welke ethische problemen men in deze praktijk van de palliatieve zorgverlening tegenkomt, hoe men daarmee omgaat en welke weerstanden er spelen. Het gesprek met de praktijk was een stap-voor-stap proces. De verschillende praktijkvoorbeelden die aan respondenten werden voorgelegd, vormden een eerste aanzet tot een gesprek, daarna vonden de interviews plaats. Het materiaal dat op deze wijze werd verzameld, staat in dit hoofdstuk centraal, vanuit de theoretische inzichten zullen verbindingen worden gelegd. 


\subsection{Definitie ethische problemen}

Aan het begin van het onderzoek werden beschrijvingen van praktijkvoorbeelden uitgereikt aan drie verpleegkundigen, drie vrijwilligers, een arts, een fysiotherapeut, de pastoraal werkster, en aan iemand van de ondersteunende diensten. Ieder kreeg twee van de vier praktijkverhalen. De verhalen waren bedoeld om het gesprek op gang te brengen en zo een beeld te krijgen van de opvattingen, barrières, gevoelens en oplossingsstrategieën waarmee mensen in deze praktijk van palliatieve zorgverlening leven en werken. Het ging om een heterogene groep waarvan zowel professionals als vrijwilligers deel uitmaakten. Deelnemers werden gekozen op basis van beschikbaarheid, dat wil zeggen dat zij de betreffende dag dienst hadden en aanwezig waren. In de gepresenteerde praktijkvoorbeelden wordt steeds een kort verhaal verteld over een situatie in de palliatieve zorg. Deze werden met een begeleidende brief aan de respondenten voorgelegd. Aan elk van de vier praktijkverhalen waren twee tot vijf vragen toegevoegd. Daarin werd gevraagd naar vergelijkbare ervaringen en hoe respondenten daar in eigen situåtie mee zouden omgaan of omgegaan zijn. Ook wordt hen gevraagd wat naar hun mening eigenlijk het probleem is waar het in het praktijkvoorbeeld om gaat, zowel voor de hulpverlener(s) als voor de patiënten die in de voorbeelden worden genoemd.

Respondenten kregen het verzoek schriftelijk, zo mogelijk nog dezelfde dag, op de vragen te reageren. Voorafgaand aan het onderzoek werden de verhalen voorgelegd aan zorgverleners uit andere palliatieve praktijken. Dit om na te gaan of de beschreven situaties herkenbaar zijn in de palliatieve zorgverlening. In de verhalen zijn ethische, emotionele en existentiële aspecten te herkennen. Zij laten zien hoe zorgverleners moeilijke situaties interpreteren en ermee omgaan. Doel van de ingebrachte voorbeelden was een indruk te krijgen van de ervaringen en opvattingen van zorgverleners in het hospice. Aan de hand van de respons zou een beeld gecreëerd kunnen worden van hoe men ethische problemen definieert, of men spanningen uit de praktijkvoorbeelden herkent en hoe men denkt over het omgaan ermee. Daarnaast leveren antwoorden op de vragen aanknopingspunten op om in de later te houden interviews nader te bespreken. De beschreven praktijkvoorbeelden zijn waar gebeurd.

In de beschrijvingen en interpretaties van reacties gaat het om verschillende groepen en individuen. Om verwarring te voorkomen noem ik ze hier: de zorgverleners in de praktijkverhalen en de respondenten (dit zijn zorgverleners in het hospice die reageren op deze verhalen). 


\subsubsection{Vier praktijkverhalen en de reacties}

\section{Praktijkverhaal $1^{7}$}

Mevrouw Van Alphen is sinds twee weken in het hospice, zij lijdt aan darmkanker. Mevrouw is een jaar of 50 , is getrouwd, zij heeft geen kinderen. De situatie is ernstig, er is sprake van een totale darmafsluiting. De patiēnte is erg zwak en moe. Ze ligt op een eenpersoonskamer. Gedurende de nacht heeft ze veel gebraakt, de inhoud van de darm die niet meer langs de normale weg het lichaam kan verlaten, komt er uit. 's Morgens ligt ze verzwakt en uitgeput in bed, ze vraagt of de arts langs wil komen. Ze vraagt haar om raad: 'Wat moet ze doen? De hele nacht is ze zo ziek geweest, nu heefi ze weer een honger gevoel. Zal ze iets eten?'

$\mathrm{Na}$ lichamelijk onderzoek legt de arts uit dat mevrouw zelf moet beslissen. Zij kan geen uitsluitsel geven: de darm is weliswaar afgesloten, maar hoe volledig dat is, kan niet met zekerheid worden gezegd. Het kan zijn dat het voedsel waar ze trek in heeft zich een weg weet te vinden door de darm. Het kan ook zijn dat het er van boven weer uitkomt. De arts acht de kans fifty-fifty.

Weer vraagt mevrouw: 'Wat moet ik doen?', waarop de arts geduldig hetzelfde antwoord geeft. Dit gesprek gaat zo een tijdje door. Ook de verpleegkundige is aanwezig en met veel geduld en toewijding maken zij mevrouw duidelijk dat zij zelf mag beslissen. Zij besloot nog wat te wachten.

Toen de arts en de verpleegkundige de kamer hadden verlaten, verzuchtte mevrouw: 'Je moet hier ook alles zelf beslissen!'

In de reacties wordt onzekerheid genoemd als grootste probleem voor de zorgverleners:

Zij hebben onvoldoende inzicht in de klinische situatie.

Het probleem is de onzekerheid over de gevolgen van het eten door mevrouw Van Alphen.

Ook voor mevrouw Van Alphen wordt onzekerheid als grootste probleem gezien:

Door haar toestand is zij uitgeput. $\mathrm{Zij}$ is bang in een vicieuze cirkel te komen.

Het is voor haar niet duidelijk wat de gevolgen van eten voor haar zullen zijn.

7 Voorbeeld ook aan de orde in hoofdstuk 2 
Respondenten wijzen er op dat zorgverleners de plicht hebben mevrouw te helpen bij haar beslissing:

Zij schuiven de eigen besluiteloosheid af op de patiënte.

Voeden of niet voeden is geen rez̈le palliatieve keuze. Er zijn mogelijkheden de eetlust af te remmen, vloeistof aan te bieden in plaats van vast voedsel.

Ik zou proberen om haar het gevoel te geven dat ik haar wil helpen en haar niet alleen laat staan.

Een dergelijke situatie hebben wij in het hospice ook meegemaakt. In de bespreking van deze situatie vonden collega-zorgverleners dat dit het moeilijkste was wat zij ooit meemaakten. Voor mij persoonlijk is een dergelijke situatie ook erg moeilijk.

Uit de reacties blijkt het te gaan om een herkenbare situatie, waarbij het grootste probleem voor de patiënte is dat zij niet weet wat te doen. Ze is moe en voelt zich hulpeloos. Respondenten menen, dat op zorgverleners de verantwoorde. lijkheid rust mevrouw voldoende te informeren om haar in staat te stellen een besluit te nemen. Hierin moeten zorgverleners verder kijken dan de vraag van mevrouw Van Alphen. Vanuit hun deskundigheid zouden zij ook andere mogelijkheden moeten aanreiken, zoals medicatie om het hongergevoel te onderdrukken, haar het gevoel geven dat zij niet alleen wordt gelaten en men weet te handelen, ook als mevrouw niet wil of kan beslissen. Zorgverleners in het praktijkvoorbeeld lijken de autonomie van mevrouw Van Alphen, haar recht om zelf te beslissen, boven alles te stellen. Dat is de boodschap die bij mevrouw Van Alphen overkomt: 'Je moet hier ook alles zelf beslissen.'

De reacties van de niet bij de concrete situatie betrokken respondenten onderschrijven het belang van autonomie, maar verwijzen ook naar de kwaliteit van de onderlinge communicatie: ' $I k$ zou aangeven dat het mij ook erg moeilijk lijkt om iets te gaan eten ondanks de honger. Ik zou proberen haar het gevoel te geven dat $i k$ haar wil helpen en haar niet alleen laat staan'; en: 'Met de patiēnte een persoonlijk gesprek voeren, niet schuwen om over eigen gevoelens te praten.'

Het ter sprake brengen wat mensen ten diepste bezig houdt, juist bij het afscheid van het leven, de situatie van mevrouw Van Alphen, is moeilijk en verhoudt zich vaak niet met de rationaliteit van het systeem. De reacties van respondenten als zou onzekerheid (gebrek aan informatie over klinische situatie en gevolgen van eten) het grootste probleem zijn voor de zorgverleners in het praktijkverhaal lijken hierop aan te sluiten. Mevrouw Van Alphen vraagt om 
hulp in de taal en woorden van het systeem (Begeman, 1995). Respondenten lijken met hun reactie over onzekerheid te suggereren, dat wanneer hen voldoende informatie beschikbaar zou zijn, adequate hulp mogelijk is. Een rationele benadering, die aansluit bij de regelethiek en het daarmee verbonden autonomiedenken. Emoties en existentiële vragen worden vaak niet gehoord of opgemerkt omdat ze zijn verpakt in rationele vragen over bijvoorbeeld wel of niet eten. Of omdat er geen woorden voor zijn, omdat mensen niet gewend zijn daarover te (mogen) praten. Oog en oor hebben voor de niet altijd expliciet genoemde behoeften en nood van anderen, vraagt openheid en een groot inlevingsvermogen en een klimaat waarin aandacht is voor de kwaliteit van communicatie. Een klimaat waarin mensen zich veilig voelen (Kunneman, 1996; 1997). Respondenten die reageerden op dit praktijkverhaal laten iets van de spanning tussen een zorgethische en een regelethische benadering zien in hun reacties op de vraag 'Hoe zou u omgaan met de vraag van mevrouw Van Alphen?'

In samenspraak met de arts een sonde laten inbrengen, zodanig dat genuttigd voedsel/vocht de maag verlaat zonder braken en medicamenten om het hongergevoel te stillen;

Ik zou haar informeren over de mogelijkheid om de eetlust af te remmen. Ik zal haar heldere vloeistoffen voorzichtig aanbieden. Ik zou ook medicijnen geven die de kans van braken zullen verminderen. Ik zal over deze mogelijkheden met nadruk praten en dan pas haar beslissing afwachten. I zal handelen naar mijn beste weten ook al zal zij geen beslissing (willen) kunnen nemen;

Ik zou haar niet in de kou laten staan of het gevoel geven dat ze er alleen voor staat;

Ik zou haar alle aandacht geven, haar niet helemaal alleen laten beslissen. Omdat ik de intentie heb een mens in nood bij te staan.

Voor sommigen was het duidelijk dat informeren en aanbieden van medische mogelijkheden de manier was om met de situatie om te gaan, anderen zochten het meer in betrokkenheid en nabijheid zonder definitief antwoord.

\section{Praktijkverhaal $2^{8}$}

De situatie gaat over een patiente die al langer in het hospice verblijft. Haar bed staat op een tweepersoonskamer. De eerste maanden ligt ze bij de deur, toen

8 Voorbeeld eerder beschreven in hoofdstuk 3 
haar kamergenote overleed is haar bed bij het raam gezet. Uiteindelijk verbleef zij meer dan drie maanden in het hospice. Mevrouw Baden is 45 jaar, de kanker waaraan zij lijdt heeft zich uitgezaaid en een van de gevolgen daarvan is dat zij een dwarslaesie heeft. Vanaf het midden van haar rug is zij verlamd. Dagelijks wordt ze, na de lichamelijke verzorging, in de rolstoel geholpen. Meestal gaat ze dan naar het dagverblijf om er te schilderen en te roken. Mevrouw is getrouwd en heeft een dochter van 19 jaar, waar ze zich veel zorgen over maakt. Haar huwelijk is niet gelukkig. Haar eigen man is ook ziek en bovendien aan alcohol verslaafd. 'Hij wil dood', vertelde ze me, 'en ik wil leven'. Mevrouw heeft geen pijn, maar de ziekte sluipt voort en het schilderen lukt niet altijd meer, hier lijdt zij erg onder. Als ze hele dagen aan bed gekluisterd is praat ze er toch steeds over dat ze verder wil met schilderen, of lekkere dingen bakken, en over haar dochter.

Een heftige darmbloeding zorgt op een dag voor een situatie waar acuut ingegrepen moet worden. Mevrouw wordt zodanig gesedeerd dat zij in een slaaptoestand komt te verkeren. De situatie wordt daarna weer stabiel, het bloeden is gestopt.

Na ongeveer 10 dagen is mevrouw rustig, in haar 'slaap', overleden.

In de reacties op de vragen als: Nadat de situatie weer stabiel was en het bloeden gestopt, hield men mevrouw toch in een slaaptoestand. Zou dit voor u een probleem zijn? En: Hoe zou u omgaan met deze situatie? kwam naar voren dat zorgverleners moeite hebben met de in het voorbeeld geschetste strategie van zorgverlenen.

Erwerd óver haar beslist.

Ik denk dat het belangrijk is om afscheid te kunnen nemen en te beslissen hoe of wat zij wil. Ga een gesprek aan met dochter en echtgenoot over verminderen van medicatie, zodat mevrouw zelf kan beslissen.

Het is belangrijk om te kunnen inschatten wat mevrouw zelf wil.

Sedatie minderen zodat mevrouw weer 'aanspreekbaar' is.

De situatie is plotseling ontstaan, er is geen echt afscheid geweest tussen moeder en dochter...

Mevrouw wilde leven, ook in verband met haar dochter, ze was er nog niet aan toe te gaan sterven. 
Als het mogelijk is, toch de slaapmedicatie afbouwen en kijken hoe ze daarop reageert.

De situatie ter discussie stellen in het teamoverleg.

In de antwoorden lopen zorgethische en regelethisch argumenten door elkaar. Het recht op autonomie van mevrouw van Baden wordt benadrukt. De eerste vier reacties zoals ' $e$ r werd over haar beslist' benadrukken het autonomiebeginsel van de regelethiek. De overige antwoorden verwijzen naar ethische opvattingen van zorgzaamheid en aandacht voor de behoefte van de patiënte, naar verantwoordelijkheid en de inzet van deskundigheid en ook naar wederkerigheid, het voortdurend afstemmen van het zorgaanbod op zorgbehoefte. Er klink onbehagen door in de antwoorden van de zorgverleners. Waar in het verhaal met name het medisch handelen in een acute situatie centraal staat, gaat het de respondenten in hun reacties ook om morele- en existentiële vragen als 'mag je iemand die nog zoveel vragen heeft en wil leven, in een slaaptoestand houden zonder daarover afspraken te hebben gemaakt?': 'Aan mevrouw kan niet gevraagd worden wat haar wens is..'; 'Ze maakte zich zorgen, ze was er nog niet aan toe te gaan sterven' Het gaat respondenten om de zorgverantwoordelijkheid en hoe daaraan te beantwoorden. Het medisch ingrijpen om mevrouw in slaap te brengen is wellicht te rechtvaardigen in de acute situatie die ontstond, haar in de slaaptoestand houden laat weinig ruimte voor reflectie, voor vragen over moraliteit en zingeving.

\section{Praktijkverhaal 3}

Het gaat om een vrouw van rond de 45 jaar, mevrouw Coblenz. Ze is weduwe, haar man is 5 jaar geleden overleden. Er zijn geen kinderen. Met haar broer heeft ze een goede relatie, hij bezoekt haar regelmatig. Mevrouw Coblenz lijdt aan blaaskanker, de groei van metastasen heeft haar immobiel gemaakt. Af en toe wordt ze in een stoel naast haar bed geholpen, meestal is ze daarvoor te moe. Ze maakt zich veel zorgen over haar conditie. Eetlust heeft ze niet, ze is erg mager geworden en dat houdt haar bezig. Ze wil graag gezonde dingen eten, voor zover ze het naar binnen kan krijgen.

Op haar deur hangt een groot papier. Nicht Stören! Het papier hangt er altijd. Als ik op een dag meehelp bij de verzorging van mevrouw, bliff ik na afloop even bij haar. Ze heeft grote donkere ogen in een uitgeput gezicht, ze vertelt over de reizen die ze heeft gemaakt met haar man. Ze heeft veel goede herinneringen aan België en vertelt daarover. Ze is eigenlijk te moe om te praten, maar vraagt toch of $i k$ bij haar wil blijven en met haar wil praten. Ze zal af en toe haar ogen dicht doen, maar dan moet ik maar gewoon doorgaan met praten, ze luistert wel. 
Ze vraagt om wat yoghurt en nadat ik dat voor haar heb gehaald, help ik haar bij het eten. Dat vindt ze fijn.

De arts die binnenkomt, ziet dat mevrouw bij het eten wordt geholpen. Zij zegt: 'Yoghurt is goed voor $u$. Maar u kunt het best zelf eten. Probeer het toch.' Mevrouw zegt dat ze daar eigenlijk te moe voor is. Maar op aandringen van de arts belooft ze zelf te zullen eten. Na twee lepels houdt ze op en neem ik het weer over.

Daarna laat ik haar alleen om te rusten en spreek af later terug te komen wanneer zij aan het middageten toe is.

De arts legt later uit dat het belangrijk is voor mevrouw te oefenen en zelfstan. dig de dingen te doen 'nu het nog kan'.

Voor drie van de vijf respondenten die dit verhaal kregen voorgelegd, een situatie die associaties opriep met soortgelijke ervaringen. Niet in de eigen werksituatie, maar wel elders in de zorgverlening: Toen mijn vader in een verpleeghuis moest verblijven, was het verboden hem te helpen bij het eten. Ik stoorde mij niet aan het verbod en mijn vader genoot er van geholpen te worden 'Kan ik een keer rustig eten'.

In de reacties komen zorgverleners op voor mevrouw Coblenz:

Aan alles zie je en merk je dat mevrouw erg moe is. Haar lichaam is op. Om haar krachten te sparen zou ik haar helpen met eten, want dat vindt ze fijn. Waarom moet mevrouw nog oefenen om zelfstandig te eten, terwijl ze waarschijnlijk binnenkort zal komen te sterven. Je plaagt haar hiermee, dat is geen palliatieve zorg.

De arts past een algemene visie 'De patiënte moet zo lang mogelijk zelfstandig blijven', toe op een individuele situatie, waarmee hij iets creëert van 'Het mid. del wordt een doel op zich'.

Mevrouw kan zelf beoordelen waar ze haar spaarzame energie nog voor wil gebruiken: haar kwaliteit van leven. Daarop ingaan zou van meer persoonlijke betrokkenheid getuigen en van grotere professionaliteit.

Grote waarde wordt toegekend aan het grondbeginsel van autonomie: mevrouw mag zelf beslissen, ook als dat niet overeenstemt met het advies van de arts:

Met het advies van de arts rekening houden en in overleg met mevrouw Coblenz proberen wat zij allemaal nog zelf kan. 
Wat mevrouw Coblenz zelf aangeeft wat ze zelfstandig wil doen.

Bespreken wat ze wil in deze situatie. Met welke doel dwing je mensen dingen te doen waar ze zichtbaar te moe voor zin?

Ik zou mevrouw Coblenz vragen wat ze wil en me daaraan aanpassen.

Vanuit de regelethiek en de zorgethiek bekeken zijn de reacties, de opvattingen van de zorgverleners die ingingen op de vragen bij het praktijkverhaal, een combinatie van beide perspectieven. De nadruk ligt op het uitgangspunt dat mevrouw Coblenz de vrijheid heeft zelf te beslissen wat ze nog wel of niet meer kan. Duidelijk is dat respondenten daarbij aandacht vragen voor wederkerigheid, inlevingsvermogen en een goed verstaan van wat de behoefte is van deze patiënte: 'Aan alles merk je dat mevrouw erg moe is'; 'Bespreken wat ze wil in deze situatie'. Die wederkerigheid, de stem van de patiënt, is noodzakelijk om af te kunnen wegen welke zorg verleend zou moeten worden.

\section{Praktijkverhaal 4}

Mijnheer Van Doorn is Nederlander, 6g jaar, hij woont al vele jaren in Wenen en is getrouwd met een Oostenrijkse vrouw. Zij hebben geen kinderen. Hij lijdt aan longkanker met uitzaaiingen in de hersenen. In zijn werkzame leven was hij bibliothecaris en in zijn vrije tijd als zanger verbonden aan een bekend Weens mannenkoor.

Als hij in de war was, verviel hij in het Nederlands. Daarom misschien ook had $i k$ veel contact met hem. Mijnheer Van Doorn is ongeveer twee maanden in het hospice gebleven, is daarna naar huis gegaan, om verder door zijn vrouw verzorgd te worden. Thuis is hij twee weken later overleden.

Als ik 'dienst' had hielp ik altijd bij zijn verzorging en hielp hem bij het middageten. Dat laatste lukte me niet altijd, de meeste vrijwilligers wilden graag voor hem zorgen. Hij was een geliefd persoon bij iedereen. Graag zochten we samen met hem, na de dagelijkse verzorging de juiste muziek voor hem uit de voorraad cd's die hij bij zich had. Er was altijd muziek in zijn kamer waar hij naar luisterde, waar hij soms bij lag te zingen.

Zijn vertrek naar huis was lang voorbereid en werd regelmatig met hem besproken. Hij wilde graag naar zijn vrouw en thuis zijn. Op de dag voor zijn vertrek was hij een beetje somber en ik vroeg welke muziek hij wilde horen. Het moest jazz zijn en ik vond een cd van Django Reinhardt en Stefan Grapelli, jazz uit de beginperiode. Hij was enthousiast toen hij de muziek hoorde, maar na enkele ogenblikken begon hij te huilen. De muziek moest aanblijven. Het huilen werd een niet te stoppen stroom van verdriet, de muziek herinnerde hem aan 
vroeger, vertelde hij, 'aan die mooie tijd, waar hij te weinig van had genoten, te weinig van had gemaakt'.

Het was moeilijk hem te troosten, het afscheid nemen van deze patiēnt viel me zwaar.

In dit praktijkvoorbeeld gaat het, meer dan in de andere beschrijvingen, mede om de gevoelens van de zorgverlener. De aard van het werk, de zorg voor stervenden, brengt met zich mee dat zorgverleners regelmatig worden geconfronteerd met emoties en existentiële nood van mensen die zij verzorgen én met die van zichzelf. Directe confrontaties daarmee hebben een resonerende werking op de eigen vragen en emoties (The, 1997b, p. 23).

Respondenten reageren heel divers op deze situatie, zij wijzen in hun reacties op 'een professionele houding':

De opstelling van de verzorger is te close. Door betrokken/emotioneel te zijn kunnen gevoelens een te sterke invloed krijgen op de professionele zorg voor de patiënt.

Degene die dat doet (muziektherapie aanbieden), moet ook in staat zijn om de consequenties te dragen. Tijd en mogelijkheden om hem te troosten.

Maar ook:

Wanneer moeten we die gevoelige snaar raken bij een patiënt en wanneer moeten we die gevoelige snaar laten rusten?

Mooi dat door de muziek het verdriet kon stromen. Waarom troosten? Juist dat 'stromen' ruimte geven. Er wel voor hem zijn.

Het voorbeeld en de reacties verwijzen naar de spanning tussen professionele eisen en individuele ervaringen en emoties, de spanning tussen systeem en leefwereld.

Respondenten hierover:

Juist dat geraakt worden maakt het werk boeiend. Te zien hoe elk mens weer op zijn eigen manier met de dingen omgaat. Niet jouw 'oplossingen' projecteren, je bent er voor die ander. Eigen emoties bij collega's, vrienden uiten. Het gaat om betrokkenheid bij de ander. 
Met het team overleggen over de gevoelens die je als zorgverleners hebt. En met de patiēnt een heel persoonlijk gesprek voeren. Niet schromen om over eigen gevoelens te praten. Dan komt er een stuk verbondenheid tussen de patiënt en mij. Envaringen steeds terugrapporteren in het team en inschatten of ik in staat ben met deze gevoelens mijn functie uit te oefenen.

Daarbij vraag ik me af waarom ik geraakt ben en waardoor precies. En: Erover praten met je collega, bijvoorbeeld een maatje.

Het zijn juist de relationele aspecten die zorgverleners aanspreken, die 'het werk boeiend maken'. Het is een zorgethisch perspectief. Aandacht voor de behoeften van de patiënt, verantwoordelijkheid en deskundigheid voor goede zorgverlening: 'Degene die dat doet, moet ook in staat zijn de consequenties te dragen. Tijd en mogelijkheden bieden hem te troosten.' De emotionele en existentiële problemen uit dit verhaal werden door respondenten herkend en in hun antwoorden werd verwezen naar het belang van communicatie en overleg, bewustzijn van de eigen gevoelens, maar ook afstand en controle van emoties. Antwoorden die aansluiting vinden bij het door Kunneman (1998) geïntroduceerde begrip van normatieve professionaliteit. Een steeds, in elke individuele situatie, zoeken naar de juiste manier om met de emoties en existentiële vragen waarmee patiënten zich geconfronteerd voelen, om te gaan. Belangrijke voorwaarde is volgens Kunneman dat zorgverleners in staat zijn een bewuste verbinding te leggen tussen de existentiële hulpbronnen van het eigen leven en de inhoud van het werk in de praktijk en het bredere maatschappelijke verband (Kunneman, 1998, p.125). De communicatieve kwaliteit van de organisatie is hiermee in het geding.

\subsubsection{Regel-en zorgethische argumenten in een spannings- volle context}

De praktijkverhalen vormden een eerste aanzet tot een gesprek met de zorgverleners uit het hospice. Het ging om situaties die door de onderzoeker werden ingebracht. Verhalen die associaties oproepen bij respondenten met soortgelijke ervaringen. In de eerste zo verzamelde reacties worden regelethische en zorgethische argumenten genoemd en is de spanning tussen systeem en leefwereld herkenbaar. Meestal slaat die spanning door naar de regelethiek met zijn nadruk op autonomie voor de patiënt en het belang van het geven van voldoende informatie om die autonomie te kunnen uitoefenen (praktijkverhalen over mevrouw Van Alphen, mevrouw Baden en mevrouw Coblenz.). In de 
reacties op de situatie van de heer Van Doorn krijgt de zorgethiek meer ruimte. Het is ook het enige praktijkverhaal waarin niet de lichamelijke en medische aspecten van de situatie centraal staan, maar waarin het ging om het omgaan met emoties van relationele betrokkenheid, gevoelens van onmacht en verdriet van zowel de heer Van Doorn als de van de zorgverlener in het verhaal. Respondenten verwijzen in hun reacties naar rechten en plichten, steeds wordt het recht om zelf te beslissen (patiënt) een belangrijk uitgangspunt van zorgverlenen genoemd, en de verantwoordelijkheid van zorgverleners om patiënten voldoende te informeren, om af te stemmen met hen en eventueel te beslissen vóór hen (mevrouw Van Alphen). Professionaliteit en emoties lijken soms op gespannen voet te staan (de heer Van Doorn). Tegelijk wordt gewezen op de verbondenheid van professionaliteit en relationele betrokkenheid. Er wordt gewezen op het belang van bewustzijn van eigen emoties, eigen existentiële hulpbronnen: 'Daarbij vraag ik me af waarom ik geraakt ben en waardoor precies'; 'Inschatten of $i k$ in staat ben met deze gevoelens mijn functie uit te oefenen'; 'Ik denk dat het belangrijk is om afscheid te kunnen nemen' en: 'Voor mij persoonlijk is een dergelijke situatie ook erg moeilijk'. Steeds ook wordt gewezen op het belang van de mogelijkheid binnen het team te reflecteren op moeilijke situaties, op spanningen en emoties, om aan te sluiten bij de leefwereld van de patiënt en om te herkennen wat in de gegeven situaties werkelijk van belang is om te doen of juist achterwege te laten. Een dialogisch perspectief. Respondenten hechten naast het belang van regels en principes aan een zorgethische benadering van situaties in de voorgelegde praktijkverhalen. Reflectie is een potentiële bron voor verandering, verwant met Giddens' (2000) life-politics, een proces dat steeds doorgaat. Individuele situaties die mensen confronteren met de beperkingen van een al te regelgeleid denken, roepen vragen op die te maken hebben met de beleving, met emoties en het belang en de uniciteit van behoeften in die concrete situaties. Volgens Nussbaum (1998, p.20) is reflectie op oordeelsvorming essentieel, 'Omdat wij alleen door reflexief te zijn werkelijk gestalte kunnen geven aan de menselijke vrijheid.' In aanmerking moet worden genomen dat het hier ging om schriftelijke reacties op praktijkverhalen die weliswaar veel herkenning opriepen, maar tegelijk een (veilige) afstand creëerden. Het ging in die verhalen om crisissituaties waarop zorgverleners uit een andere, vergelijkbare praktijk werden uitgenodigd te reflecteren. In het vervolg van het onderzoek zal de betekenis van communicatie en reflectie voor deze zorgverleners steeds meer vanuit de eigen praktijkervaringen aan de orde komen. 


\subsection{Etische probleemsituaties}

\subsubsection{Diepte-interviews}

Er werden in totaal zeventien mensen geïnterviewd, vier in de proeffase, voorafgaand aan het eigenlijke onderzoek en dertien in het hospice tijdens het veldwerk. Doel, plaats en tijd van de interviews werden vantevoren met betrokkenen afgesproken. Meestal vond het interview plaats in de werktijd van de geïnterviewde, soms ook kwamen mensen hiervoor in hun vrije tijd naar de afgesproken plaats. De bereidheid tot deelname was geen probleem. De interviews werden op de band opgenomen. De uitgetypte weergave ervan werd aan de geinterviewde ter verificatie voorgelegd. Dit leidde in geen van de gevallen tot herziening van de tekst. Dat het aantal interviews voldoende was bleek uit de verzadiging die optrad, interviews leverden op een gegeven ogenblik geen verrassingen, geen nieuwe of opvallende ervaringen of inzichten meer op. Er bleek veel overeenstemming in de dingen die werden gezegd door de geïnterviewde zorgverleners. Gevraagd werd naar ervaringen van respondenten:

Kunt $u$ een voorbeeld noemen van een situatie waarin $u$ het heel moeilijk vond om er achter te komen wat de zorgbehoefte was van de patiënt?

En: Als u terugkijkt op deze situatie vindt $u$ dan dat dit een voorbeeld is waarin goede palliatieve zorg is geboden door $u$ en andere zorgverleners?

Ook werd gevraagd naar situaties die naar de mening van de geïnterviewde juist heel goed waren geweest:

Kunt $u$ me vertellen wat het goede was, waar zat het ' $m$ precies in? Als $u$ kijkt naar $u w$ eigen bijdrage hieraan, van welke momenten zegt $u$ dan, dat waren goede momenten?

Hoewel het ging om vragen die gestructureerd waren rond de bedoeling van het onderzoek, bleef het interview open. Dat wil zeggen dat er veel ruimte was voor de geïnterviewden om accenten te leggen en uit te weiden over de aangereikte en de persoonlijke issues, om daarover te vertellen of erop door te gaan. In de interviews kwamen ethische principes, voor zorgverleners belangrijke uitgangspunten, ter sprake. Soms gebeurde dat spontaan, aan de hand van de ervaringen. Of in antwoord op vragen als: Wat heeft $u$ bewogen juist voor palliatieve zorg te kiezen? En: Welke eisen stelt $u$ aan uzelf in $u w$ werk? In andere gevallen werd aan het eind van het interview de vraag specifiek gesteld: Kunt u mij een aantal ethische principes, normen of waarden noemen, die een belangrijke rol spelen in uw werk?

Doorpratend over belangrijke uitgangspunten en praktijkervaringen kwam een scala van ethische probleemsituaties aan de orde en werd gesproken over 
de rol van communicatie en reflectie. Problemen hadden te maken met de positie van de patiënt, van de familie en die van de zorgverlener zelf binnen de organisatie waarin hij of zij functioneert. Ook werd gevraagd naar positieve ervaringen en naar het communicatieve klimaat. Wat waren goede momenten? Wat zou $u$, achteraf gezien, anders willen doen? Heeft $u$ het idee dat $u w$ werk gewaardeerd wordt door patiënten en hun naasten? Wordt uw inbreng gewaardeerd in het team van zorgverleners?

Interpretatie van de interviews vond plaats door het interviewmateriaal te ordenen in een aantal thema's. Dit door bij het rustig doorlezen van het materiaal te zoeken naar betekenisvolle onderwerpen in de uitspraken en ervaringen van respondenten. De onderwerpen die werden geselecteerd waren: communicatie, moeilijke zorgsituaties, opvattingen over goede zorg, over ethiek en over autonomie. Doel van de interviews was voornamelijk materiaal te verzamelen voor een samenspraak met betrokkenen en inzicht te krijgen in de praktijk, de ervaringen en ethische probleemsituaties. Door verscheidene mensen die op verschillende manieren direct bij de zorgverlening waren betrokken voor deze interviews te benaderen, ontstond een beeld van deze praktijk, van de problemen en spanningen die men tegenkomt en van de manieren om daarmee om te gaan.

De zorg voor en om anderen confronteert mensen regelmatig met situaties waarin het moeilijk is te bepalen wat goede zorg is, welk beroep ervan uitgaat en hoe daarin te handelen. Ethiek in de praktijk heeft een dialogische structuur omdat het goede, de intentie daartoe, niet alleen verbonden is met eigen opvattingen, maar altijd ook met die van anderen: de patiënt waarmee men te maken heeft, de familie en andere zorgverleners. Het gaat daarbij om professionele opvattingen en om inzichten en gevoelens die nauw verbonden zijn met de eigen achtergrond en leefwereldervaringen. Daarnaast heeft het zoeken naar het goede, naar wat juist en rechtvaardig is in situaties die zich in de zorgverlening voordoen, te maken met de regels en de cultuur van de instelling. Gegevenheden die ervaren kunnen worden als grenzen en belemmeringen, verankerd in het brede systeem van wet- en maatschappelijke regelgeving. $\mathrm{Zij}$ kunnen in moeilijke situaties spanning oproepen en mensen confronteren met emoties en existentiële vragen.

Een regelmatig voorkomende moeilijke situatie bleek het overplaatsen van patiënten van het hospice naar een verpleeghuis. Een voorbeeld van een situatie die regelmatig veel spanning oplevert in het hospice en ethische, emotionele en existentiële vragen oproept. Spanning die te maken heeft met regels (systeem) en behoeften die in individuele situaties centraal staan en zijn verbonden met de leefwereld van betrokkenen; spanning die verwant is met die 
tussen regelethiek en zorgethiek. Het hospice kent een opname- en verblijfbeleid. Opname is bedoeld voor mensen die dat in de laatste fase van hun leven nodig hebben. Dit bijvoorbeeld door gebrek aan thuiszorg, mantelzorg, of omdat pijn of andere symptomen thuis niet goed behandeld (kunnen) worden. De algemene richtlijn voor de duur van het verblijf is drie maanden. Omdat de situatie van de patiënt door de zorg in het hospice soms verandert en stabieler wordt, waardoor het levensperspectief verschuift, moet in die situaties worden gezocht naar een andere opvangmogelijkheid. Als de patiënt niet terug naar huis kan, wordt een plaats gezocht in een verpleeghuis. Voor sommige patiënten is dat een probleem. Hun opname in het hospice zagen zij als een 'laatste verhuizing'. Daarnaast heeft het verpleeghuis bij de meeste mensen een slecht imago. Het is voor velen een schrikbeeld. Soms zien zij er zo tegenop dat de lichamelijke situatie door de 'dreigende' overplaatsing weer verslechtert en besloten wordt de overplaatsing niet door te laten gaan. Hierdoor verblijven sommige patiënten regelmatig toch veel langer dan drie maanden in het hospice, hetgeen voor sommigen vanuit verschillende motieven als problematisch wordt ervaren.

Wat is de reden, dat bijvoorbeeld mijnheer $X$ al een jaar in het hospice verblijft en mevrouw A. moet verhuizen? (verpleegkundige, hospice).

Het gebeurt wel eens dat een patiënt hier wordt opgenomen voor pijn en benauwdheid. Als dan die klachten minder zijn en de patiēnt kan, om wat voor reden dan ook, niet terug naar huis, dan moeten we hem doorverwijzen naar een verpleeghuis. En vervolgens overlijdt die patiënt twee weken later na heel veel stress omdat hij daar eigenlijk niet wilde zijn. Dat vinden we dan heel erg moeilijk (verpleegkundige, proefinterview).

Ik dacht bij mezelf: hier lig ik op de goede plek. Ik ben ook heel even bang geweest. Iemand had tegen me gezegd: maar als je hier te lang ligt, dan kom je in een verpleeghuis terecht. En toen ben ik een poosje van streek geweest (patiënte, hospice).

Om zo iemand nog te verplaatsen, nee ik geloof niet dat dat juist is. Dat is een van de grote dilemma's waar we mee zitten en waarvan ik hoor dat het in andere hospices ook zo is, dat mensen daar tegenaan lopen. Zeggen 'de patiënt hoort hier niet (langer)', is iets waarvan mijn haren overeind gaan staan. En onze ervaring is ook, dat als mensen overgeplaatst worden, zij toch snel komen te overlijden. Ik heb er geen antwoord op... (verpleegkundige, hospice). 
In dit soort moeilijke situaties worden zorgverleners en patiënten geconfronteerd met existentiële problemen, die niet verenigbaar zijn met hun opvattingen en beleving van goed leven, van goede zorg (zoals het uitgangspunt van autonomie, het respecteren van het zelfbeschikkingsrecht van de patiënt): ' $I k$ ben het daar niet mee eens...' ;'Ik heb daar geen antwoord op...' ;'Ik ben toen een poosje van streek geweest...'

Autonomie, als het recht van zelfbeschikking van patiënten, bleek ook in andere situaties problematisch. Bijvoorbeeld in de situatie waarin een patiënt die pijnbestrijding weigert. Een situatie die voor veel zorgverleners moeilijk is te accepteren of mee om te gaan:

Want wat is dat ontzettend moeilijk als je iemand zo ziet lijden en hij weigert pijnbestrijding. Daar kon het gros van de mensen heel moeilijk mee uit de voeten (vrijwilliger, proefinterview).

Ook de familie van de patiënt is bij de zorg betrokken. Soms roept die zorg problemen op, het stervensproces kan hen te zwaar vallen, te lang duren. Soms ook stemmen ideeën of verwachtingen over goede zorg niet overeen met die van de zorgverleners:

Het komt regelmatig voor dat de familie het wachten te lang duurt. De familie zit de tijd uit te zitten tot de patiēnt eindelijk gaat overlijden. Soms heb ik dan het gevoel van 'Geef hem wat meer tijd'. Ook binnen het team heb ik wel eens het gevoel van 'Goh, is ze nog niet dood?' Zeker bij mensen die dan al een pompje hebben en niet meer aanspreekbaar zijn. Dat is heel zwaar voor de familie, maar ook wel voor de patiênt denk ik. Je kunt dat niet beoordelen of het nog heel erg is, of... (verpleegkundige, hospice).

Het moeilijke in deze situaties is voor zorgverleners dat patiënten zelf niet meer in staat zijn aan te geven wat goed is. De familie heeft afscheid genomen, het wachten en de voortdurende confrontatie met de stervende valt hen op den duur heel zwaar. Ook zorgverleners vragen zich af 'Wat is goede zorg in deze situatie?' 'Heeft de patiënt nog pijn, nog andere behoeften?' 'Hoe kunnen we de familie ondersteunen?' Voorbeelden ook van de spanning tussen het medisch technische en menselijk wenselijke handelen en opnieuw de verschillende opvattingen daarover:

Als ik 's morgens kom en een arts heeft bijvoorbeeld afgesproken met een collega van hem: 'Natuurlijk mag die pomp verhoogd worden.' Ik heb dan zoiets van: 'Nou de klachten zijn bestreden, dat doe ik niet, want naar mijn idee gaat dat 
te ver (pomp verhogen). Dat kan ik voor mezelf niet verantwoorden en ik zeg het dan, en vervolgens krijg ik natuurlijk de hele familie over me heen (verpleegkundige, proefinterview).

Wat palliatieve zorg tot goede zorg maakt, waar dat precies in zit, of wat juist maakte dat het niet goed was, was waarop ik doorvroeg op de praktijkvoorbeelden van respondenten. Er werden meerdere voorbeelden genoemd van zorgsituaties die men moeilijk vond, zoals de situatie waarin volgens de zorgverlener niet serieus genoeg werd omgegaan met de vragen en behoeften van de patiënt, met name wat betreft euthanasie en ten aanzien van de privacy van de patiënt. Voorbeelden waarbij de spanning tussen systeem en leefwereld het interpreteren van de zorgvraag onder druk zet en zorgverleners confronteert met emoties en existentiële vragen:

Ik bedoel, als iemand om euthanasie vraagt en als je er van uitgaat dat die vraag op dat moment binnen de regels valt. Ja dan zit er maar een ding op....In plaats van te gaan rekken, van 'misschien hebben we nog wel wat anders te bieden', en 'zouden we niet...(verpleegkundige, hospice).

Wanneer men wil dat de medicatie van pijn-en slaapmiddelen verhoogd wordt, eigenlijk met het doel dat de patiënt niet te lang meer zal leven. Maar er zijn geen afspraken over gemaakt... (verpleegkundige, proefinterview).

Er werden problemen gesignaleerd op het gebied van privacy voor de patiënt en zijn familie. Situaties die zorgverleners confronteren met enerzijds professionele opvattingen en systeemeisen en hen tegelijk plaatsen voor ethische dilemma's en existentiële vragen:

Ik vind het wel eens moeilijk als mensen hun intiemste dingen aan mij verteld hebben, hun pijn, hun machteloosheid en schuldgevoel. Hoeveel geef ik daarvan door aan het team? Natuurlijk vind ik dat ik dingen moet rapporteren naar anderen. Maar wat zeg ik wel, wat zeg ik niet? (verpleegkundige, hospice).

Wat ik ook het hele moeilijke van de palliatieve zorg vind, is omdat je met zoveel vrijwilligers werkt, er zo ontzettend veel gezichten aan het bed komen (zorguerlener, proefinterview).

Ik vind dat echtparen, dat hebben we hier ook meegemaakt, te weinig gelegenheid hebben om hun intimiteit te beleven. Ik vond het heel schrijnend. Ze sliepen wel bij elkaar op de kamer, maar dat was het dan (verpleegkundige, hospice). 
In de interviews noemden zorgverleners onderwerpen als de onzekerheid over een toekomstperspectief en zorg voor de zorgers. In de periode waarin de interviews plaatsvonden bestond er veel onzekerheid over het voorbestaan van hospicevoorzieningen. Deze onzekerheid betekende voor sommige zorgverleners een extra belasting voor het functioneren. Samenhangend daarmee de beperkingen waarmee zorgverleners worden geconfronteerd:

We hebben een slecht geweten tegenover de vrijwilligers. Die hebben het ook zwaar. Die komen vaak maar één keer in de week en de volgende week is die patiēnt weer gestorven. De enige patiënt die hij gekend heeft is alweer dood. En dan gaat hij weer verder. Eigenlijk zouden we met die persoon willen praten als we weten dat hij een goed contact had met de patiënt die is gestorven (pastoraal werker, proefinterview).

De interviews geven een beeld van de praktijk, de spanning, de moeilijke situaties en emoties van betrokkenen. De situaties die problematisch worden genoemd, geven een indruk van achterliggende opvattingen over wat goed is, over waarden en normen, en de motivatie van zorgverleners uit de interviews. Het probleem van overplaatsing van patiënten die dat niet willen, maar ook de vragen over privacy, zijn voorbeelden van de spanning tussen systeem en leefwereld, tussen de rationele regels en de vragen, emoties en verwachtingen van mensen in individuele en moeilijke situaties. Problemen zoals het verhogen van pijn- en slaapmedicatie zonder dat de patiënt is ingelicht en het voorbeeld van de zorgverlener die er moeite mee heeft dat patiënten die om euthanasie vragen nog iets anders wordt aangeboden verwijzen naar de voorwaardenscheppende rol van communicatie om ethische vragen of problemen te herkennen en er mee om te gaan. Dat wil zeggen wanneer in die situaties de dialogische structuur van ethiek in de praktijk geweld is aangedaan staat het morele concept van zorg, waarin behoeften van anderen uitgangspunt zijn, onder druk.

De verschillende perspectieven waarmee een moreel probleem in de praktijk wordt benaderd en geînterpreteerd, brengt een emotionele geladenheid aan (Verkerk 2000, p. II5), waardoor het spreken erover en het omgaan met deze moeilijke situaties vaak als beperkt wordt ervaren. De vragen blijven. Trage vragen noemt Kunneman (1999) ze. Traag, omdat ze steeds opnieuw worden gesteld en de situaties waardoor ze worden opgeroepen, zich in allerlei vormen blijven herhalen en soms onoplosbaar lijken. Traag ook omdat degenen die de vragen stellen, te maken hebben met emoties en existentiële pijn, die zich niet verhoudt met de rationaliteit van de systeemwereld. Daardoor dreigen de vragen te verstommen 'Ik heb er geen antwoord op';'Wat zeg ik wel, wat zeg ik niet'. 
Tegelijk bergen deze trage vragen de mogelijkheid in zich van een dynamiek die morele, emotionele en existentiële vragen steeds opnieuw op de agenda houdt en die de spanning van de rationaliteit en dwingende macht van systeemeisen aantast. Of dit theoretisch perspectief een praktische realiteit is voor de betrokkenen laat zich nog bezien. Misschien is de wens de vader van de gedachten. De dynamiek kan te traag blijken voor beweging of balans, ook de ontwikkeling van systemen staat niet stil, gaat steeds door. Theorie en praktijk lopen niet eenvoudig in elkaar over.

Voorwaarde voor de dialogische structuur van ethiek in de praktijk is dat men zich bewust is van eigen intenties en opvattingen. In het interview werd ernaar gevraagd. Het beeld van goed leven, van goed sterven, van goede zorgverlening, blijkt niet vast te liggen. Het verschuift (Kunneman, 1998), afhankelijk van de positie die men inneemt, de ervaringen die men opdoet en de inzichten of de vragen die daaruit voortkomen. Wat goed is wordt zo steeds opnieuw belicht en begrepen, terwijl 'het goede' tegelijk ongrijpbaar blijft en verhuld. Bewustzijn van eigen opvattingen en existentiële bronnen, deze integreren in de structurele kaders van de professie waarvan men deel uitmaakt, zijn voorwaarden voor een zoektocht naar een juiste omgang met ethische problemen in de praktijk. Kunnemans opvatting van normatieve professionaliteit is een terugkerend thema, dat is verbonden met kwaliteit van communicatie in de zorg voor patiënten en in de omgang met elkaar (Kunneman, 1998, p.r26).

Zorgverleners spraken zich in de interviews uit over voor hen belangrijke uitgangspunten voor zorgverlening in het hospice. In de motivatie om juist voor de palliatieve zorg te kiezen werden redenen genoemd die verwezen naar onvrede met andere zorgverleningsituaties zoals verpleeghuiszorg en de zorg in ziekenhuizen, maar ook naar existentiële vragen over de betekenis van leven en dood en naar de behoefte goed te doen, iets te betekenen voor mensen in moeilijke situaties. Reacties vanuit een relationeel mensbeeld:

Ik heb hier het meest het gevoel dat ik kan doen voor de mensen wat ik ook echt voor ze wil doen. Dat ik zorg kan bieden waar ik ook echt achter sta. En: Ik vind het ideaal om met $z$ 'n allen in ieder geval te proberen om iemand nog juist dat te geven, wat hij eigenlijk zelf nog wil (verpleegkundige, hospice).

Al van jongs af aan heb ik me bezig gehouden met levensvragen van: Waarom en waar leidt dit toch allemaal toe (fysiotherapeut).

Ik ben wel afgeknapt op de 'wijk' van nu, want daar ligt mijn hart nog wel hoor. Alleen niet zoals het nu moet, met een stopwatch langs stervende mensen. Ik kan het niet meer verkopen (verpleegkundige, hospice). 
Het kleinschalige trok me heel erg aan, maar ook de wetenschap dat je hier zorg kunt verlenen op een manier waar mijn hart nog steeds bij lag. De tijdsfactor speelt daar een belangrijke rol in, want dat vind je in de instellingen niet meer (verpleegkundige, hospice).

Uit ervaring en omdat ik me prettig voel, me aangetrokken voel tot de laatste zorgverlening aan mensen, dat een heel belangrijk deel van mensen hun leven vind (pastoraal werker).

Iets voor anderen doen, dat heb ik altijd graag gedaan. Deze mensen hebben je hulp hard nodig, ze zijn kwetsbaar. Er is weinig, denk ik, voor deze mensen en daarom vind ik het leuk om ze iets te geven, iets extra's te geven (vrijwilliger, hospice).

Het valt op, dat de meeste respondenten, bewust van hun drijfveren, een beeld schetsen van een samenleving die zou moeten opkomen voor kwetsbaren en dat zij voor zichzelf daartoe mogelijkheden zien in kleinschalige projecten als hospicevoorzieningen. Een beeld waarin de kernwaarde van de zorgethiek herkenbaar is: 'zorg als belangrijkste betrekking tussen mensen onderling en tussen mensen en hun omgeving' (Manschot, 1997 p. IO2). Of zoals Verkerk (I997, p. 54) de morele houding van zorg formuleert: 'zorg als het gevoelsmatige en ondersteunend antwoord op de situatie en omstandigheden van de kwetsbare en hulpbehoevende medemens.' Respondenten reageerden op de vraag over de eisen die het werk stelt regelmatig met het verwijzen naar de eigen kwetsbaarheid. Niet als negatieve waarde, maar juist iets wat ruimte biedt, wat er mag zijn. Maar ook naar kennis en kunde en palliatieve zorg als verpleegkundig specialisme.

Je inleven in mensen die hier komen (receptionist/gastheer, hospice).

Ik denk niet dat ik voldoende ben toegerust. Ik vind dat ik elke dag dat ik daar ben nog zoveel leer van mensen, van hoe dingen gaan. Of ze nu goed of fout gaan (vrijwilliger, proefinterview).

Dat ik hier kan zijn, gewoon als mens. Met mijn eigen kwetsbare stukken maar ook met mijn vaardigheden en mijn vermogen om te luisteren (verpleegkundige, hospice).

In al die jaren dat ik hier op deze manier bezig ben, ervaar ik steeds meer dat ik het niet weet. Gewoon proberen zo blanco mogelijk bij mensen binnen te komen. Ik ervaar pastor zijn heel sterk als reisgenoot zijn (pastor, hospice). 
Ik vind wel dat het een specialisme is of zou moeten zijn (verpleegkundige, hospice).

Veel genoemd werden uitgangspunten als: respect voor mensen zoals ze zijn, niet oordelend zijn, respect voor het leven. Een uitgangspunt dat door vijf van de geïnterviewden werd genoemd, soms ook met andere woorden:

Aandacht en waardering voor elkaar binnen het team (vrijwilliger, hospice).

Zorgvuldig omgaan met vertrouwen van de patiēnt en zijn of haar familie. Grenzen die mensen stellen respecteren (verpleegkundige, hospice).

Respect voor de mens zoals hij is, ik denk dat dat het belangrijkste is (verpleegkundige, hospice).

Belangrijk uitgangspunt is de menselijke nabijheid. En: geduld hebben met elkaar, het uithouden en samen dragen wanneer individuele zorgsituaties moeilijk zijn om mee om te gaan (pastoraal werker, proefinterview).

Ik geloof dat in het aangezicht van de dood zoveel gerelativeerd kan worden, dat het op het wezenlijke aankomt: dat men hier eenvoudig de mensen open tegemoet kan treden, ook binnen het team (pastoraal werker, proefinterview).

Eerlijkheid. Open en eerlijk zijn. De patiënt heeft recht op informatie (verpleegkundig coördinator, proefinterview).

Daarnaast werd autonomie met name door vijf van de geinterviewden genoemd, evenals het uitgangspunt van verantwoordelijkheid, zei het vaak in andere omschrijvingen. Uitgangspunten die soms sterk met elkaar verweven zijn:

$I k$ vind het belangrijk dat degene om wie het gaat het heft in eigen handen houdt. Dat hij bepaalt wat er gaat gebeuren en dat je ook mee moet gaan in die wensen, of het nu om pijnbestrijding gaat, of over het niet vol willen houden, of in de boosheid blijven steken...(vrijwilliger, hospice).

Het gaat om kwaliteit van leven, elke dag. Het meest storende element in de terminale fase is, dat mensen hun onafhankelijkheid inleveren. Daaraan een bijdrage te kunnen leveren, dat mensen nog dingen zelf kunnen doen, is heel belangrijk (fysiotherapeut, hospice). 
Zelf alles regelen, afscheid nemen, organiseren uitvaart, bijleggen van oneffenheden in (vriendschaps)relaties (patiënte, hospice).

Aandacht voor 'Hoe ver moet je gaan, ook in de palliatieve behandeling'. Het moet echt de kwaliteit van het leven ook beter maken (arts hospice).

Bewaken van de autonomie van de patient, ook de eigen autonomie (pastoraal werker, hospice).

Herkenbaar zijn zowel regelethische als zorgethische uitgangspunten. Uitgangspunten als rechtvaardigheid en autonomie geven richting aan het denken over situaties als overplaatsing naar een verpleeghuis, wanneer de patiënt pijnmedicatie weigert en wanneer de vraag om euthanasie binnen de wettelijke kaders past. Voor de patiënt is een gevoel van veiligheid belangrijk. Relationele aspecten spelen een belangrijke rol in de betrokkenheid en verantwoordelijkheid voor elkaar en de patiënten. In de reacties zijn ze verwoord in uitspraken over het respect voor de eigenheid, voor de belevingswereld van aan de zorg toevertrouwde patiënten, voor hun privacy, over de zorg voor vrijwilligers en de zorg voor de familie van patiënten.

\subsubsection{Omgaan met ethische problemen}

Doorvragend op praktijkervaringen die respondenten inbrachten, probeerde ik een beeld te krijgen van de rol die communicatie speelt in het omgaan met moeilijke situaties en wat daarnaast mogelijk van invloed is. De dialogische structuur van ethiek betekent niet altijd een garantie voor een oplossing of het bereiken van consensus. Veel is bovendien afhankelijk van de kwaliteit van die dialoog (Gadamer, 1986), van communicatieve openheid en een klimaat waarin mensen zich veilig en gerespecteerd weten en waar men gevoelig is voor symbooltaal, voor datgene wat mensen niet onder woorden kunnen brengen (Keirse, 1996, Kunneman, 1998 p. 124).

Tijd, aandacht, behoefte aan onderlinge steun en uitwisseling waren begrippen, waarmee respondenten reageerden op vragen die hierop betrekking hadden. Ook als er te weinig tijd is, biedt een klimaat waarin men samenwerkt en waar de bereidheid voelbaar is naar elkaar te luisteren, soelaas. Een minimumvoorwaarde, wil de spanning tussen het instrumenteel mogelijke en het menselijk wenselijke niet te veel oplopen. 
Er is niet altijd tijd genoeg, er is eigenlijk te weinig tijd maar ik geloof dat wij allemaal de behoefte hebben elkaar te ondersteunen. Alleen al die bereidheid daartoe maakt ons vaardig, ook in korte tijd elkaar eenvoudig het gevoel te geven dat we elkaar dragen, dat we elkaar behulpzaam zijn (ziekenverzorgende, proefinterview).

Er is weinig uitwisseling van ervaringen en reflectie op moeilijke zorgsituaties met collega's mogelijk doordat vaak alleen gewerkt wordt, men ziet elkaar niet veel. Eén maal per maand teamoverleg is weinig, niet alles kan dan besproken worden (verpleegkundige, hospice).

Tijdens het teamoverleg is er weinig aandacht voor ethische problemen, vaak onvoldoende gevoel van veiligheid voor het delen van moeilijke ervaringen en eigen opvattingen (verpleegkundige, hospice).

Een tijdje geleden hadden we een patiënt die iedere keer wegzakte in de stoel, en dan zeg ik ook 'Is het niet beter dat we eens een kussen of zo, onder zijn arm of rug doen'. En ja, dan wordt dat serieus genomen door het verplegend team. Er wordt niet zo naar je gekeken van 'Nou zeg, daar heb jij niets mee te maken' (huishoudelijke dienst, hospice).

Wanneer de dialoog hapert, kan de spanning (te) hoog oplopen hetgeen voor zorgverleners persoonlijk een zware belasting kan betekenen. Men voelt zich bekneld tussen de persoonlijke waarden en de realiteit, waarin instrumentele belangen soms voorgaan.

Ik herinner mij een jonge vent, die heel veel problemen heeft gehad in zijn leven. Hij kwam uit een orthodox milieu en had dan ook heel veel moeite zijn problemen bij mij neer te leggen. Toen dat vertrouwen er eenmaal was, bleek hij hier niet op zijn plaats en moest worden overgeplaatst naar een verpleeghuis. Dat heb ik toen domweg laten gebeuren. Ik heb niet veel tegenwerpingen gemaakt omdat ik dat al een keer daarvoor gedaan had en dat was een beetje geëscaleerd. Dus ik dacht 'dit keer hou ik me er maar een beetje buiten'. Ook om mezelf te beschermen, ik kan niet steeds die confrontaties aan. Daarna is die man toch na een maand overleden in het verpleeghuis. Er waren ook nog ouders in het spel. Die ouders zeiden daarna, Wij begrepen niet waarom hij bij jullie weg moest. Ik wist niet wat ik moest zeggen'(verpleegkundige, hospice).

Dat een dialoog niet altijd een oplossing brengt, is niet het grootste probleem. Waar deze zorgverlener onder leed, was juist dat de weg naar overleg en dia- 
loog werd geblokkeerd door eerdere ervaringen. Het vertrouwen dat met deze patiënt was opgebouwd, werd ondergraven. Niet zo zeer door de overplaatsing op zich, maar door het feit, dat over deze ingrijpende gebeurtenis onvoldoende overleg was geweest met de betrokkenen. De betreffende zorgverlener ervaarde dit als een persoonlijk falen, maar zag tegelijk geen mogelijkheid er anders mee om te gaan.

Waar mensen op elkaar zijn aangewezen, waar zorgverleners rechtstreeks ingrijpen in het bestaan van patiënten en hun naasten, in dergelijke situaties hopen mensen, dat zorgvuldig zal worden omgegaan met hun kwetsbaarheid. Om daartoe in staat te zijn, dienen zorgverleners volgens Kunneman (1998), hun technische competenties te kunnen integreren in de eerder genoemde normatieve professionaliteit. Hetgeen slechts mogelijk is binnen een klimaat van vrije communicatie waarbinnen ruimte is voor emoties en ervaringen (professionele-én levenservaringen).

Doorvragen naar waar goede ervaringen nu precies die kwalificatie aan te danken hadden, waar ' $m$ het goede in zat, leverde reacties op als:

Een van de belangrijkste behoeften van patiënten die hier komen is rust. Maar hoe hij die rust wil, dat weet je niet meteen. Je moet heel alert zijn en attent, ook op wat de familie aangeeft, want die hebben het hele proces meegemaakt (verpleegkundige, hospice).

Het grote verschil met het ziekenhuis waar moeder was, is dat men hier, de arts ook, mét de patiënt spreekt. En er ook naast gaat zitten en de hand vasthoudt en aan de schouder en wat dan ook. Dat men met de patiënt spreekt en niet aan het voeteinde staat en het óver de patiēnt heeft met een collega. Het werd gewoon met mijn moeder besproken en pas daarna werden de aanwijzingen aan de zuster of aan de co-assistent gegeven. En dat scheelt als er gewoon wordt geluisterd naar waar je last van hebt (dochter van overleden patiēnte).

Heel belangrijk is pijn- en symptoombestrijding en goede interdisciplinaire samenwerking. Tijd voor familie, tijd voor zorgverleners onderling, een aangenaam huiselijk klimaat voor de patiënten (ziekenverzorgende, proefinterview).

De behoefte aan eigen inbreng en eigen verantwoordelijkheid kwam naar voren in het interview met een patiënt: $I k$ kan zelf bepalen wanneer ik douche. Ook dat de fysiotherapeut komt en wanneer...Ook rust werd veel genoemd, zorgverleners, maar ook patiënt en familie noemden het belang van het creëren van rust en een gevoel van veiligheid: En ineens ging er echt rust over me heen. Dat ik dacht bij mezelf, hier lig ik op de goede plek. Toen had ik rust (patiënt). 
Ja en veiligheid, dat mensen zich veilig voelen. Dat is vaak een van de driffueren waarom mensen worden opgenomen. Omdat ze zich niet meer veilig voelen thuis, doordat er niet snel genoeg op pijn kan worden ingespeeld of op benauwdheid, wat natuurlijk heel angstig is. Of omdat de patiênt ziet dat de familie het bijna niet meer aankan. Dan is het ook heel moeilijk voor de patiēnt om rust te vinden als je ziet dat je familie de uitputting nabij is (zorgverlener, hospice).

Samenvattend kunnen we stellen dat uit de reacties van respondenten theoretische concepten vanuit de geleefde werkelijk aan het licht komen (Abma, 1996 p.92). In de door hen genoemde opvattingen en situaties klinkt zowel een zorg- als een regelethische benadering van de zorgpraktijk door. De zorgethische benadering blijkt met name uit het belang dat men hecht aan de rol van communicatie. Communicatie is belangrijk, niet alleen in de aandacht voor de zorgvraag, maar ook in het organiseren van de zorg en de deskundigheid die nodig is in individuele situaties. De wisselwerking die uitgaat van het onderlinge afstemmen zowel binnen het team als ten aanzien van zorgbehoeften van patiënt en familie wordt belangrijk gevonden, evenals een klimaat van veiligheid en onderling respect dat daaraan bijdraagt: 'Alleen al de bereidheid daartoe maakt ons vaardig'. Gebrek aan communicatieve ruimte en openheid levert spanning en emotionele belasting op voor betrokkenen. 'I k kan niet steeds die confrontatie aan'; 'Eenmaal per maand teamoverleg is weinig, niet alles kan dan besproken worden'; 'T $k$ wist niet wat ik moest zeggen...' Opmerkingen over te weinig tijd en mogelijkheden voor communicatief overleg en uitwisselen van ervaringen keerden steeds terug.

Ook regelethiek speelt een rol, vooral waar het gaat om het 'bewaken' van de autonomie van patiënten zoals dat opklinkt in reacties als: 'Het meest storende element in de terminale fase is, dat mensen hun zelfstandigheid inleveren' en 'Ik vind het belangrijk dat degene om wie het gaat, het heft in eigen handen houdt'. Dat die opvattingen geen strak keurslijf zijn, maar open staan voor nuancering door (leefwereld)ervaringen, kan worden beluisterd in reacties als: ' $I k$ geloof dat in het aangezicht van de dood zoveel gerelativeerd kan worden, dat het op het wezenlijke aankomt: dat men hier eenvoudig de mensen open tegemoet kan treden'.

De spanning tussen systeem en leefwereld die morele en existentiële vragen onder druk zet, loopt als een rode draad door de gesprekken. Voorbeelden zijn de frustraties (zorgverleners) en angst (patiënt) met betrekking tot het overplaatsen van patiënten. Maar ook het gevoel te kort te schieten ten aanzien van de privacy van patiënten en te weinig tijd en aandacht te hebben voor vrijwilligers en voor reflectie op moeilijke situaties. 


\subsection{Samenspraak in groepsbijeenkomsten}

Naast het inzichtelijk maken van de praktijk van de palliatieve zorgverlening waren de interviews bedoeld om groepsbijeenkomsten te organiseren, een samenspraak op gang te brengen om door te praten over thema's uit de reacties van respondenten. Het interviewmateriaal werd geordend naar thema's ethiek, communicatie en moeilijke situaties. Er werd één bijeenkomst georganiseerd met professionals en één met vrijwilligers. In de bijeenkomsten werd het thema communicatie aan de orde gesteld. Respondenten werden per brief uitgenodigd, waarin doel, tijdstip, plaats en tijdsduur werden bekendgemaakt. De groepen bestonden voornamelijk uit vrouwen. De groep professionals bestond uit elf mensen, onder wie één man, de vrijwilligers waren met z'n twaalven, elf vrouwen en één man. De bijeenkomsten namen anderhalf uur in beslag. Zij werden op de band opgenomen en volledig uitgetypt, waarbij van de bijeenkomst van de professionals een deel op de band gemist werd doordat het bandje niet op tijd werd omgedraaid.

\subsubsection{De professionals}

De kwaliteit van de communicatie, het klimaat waarin mensen samenwerken, is een belangrijke factor in het streven naar kwaliteit van zorgverlenen (Kunneman, 1998). De onmacht die zorgverleners soms ervaren om gevoelens ter sprake te brengen, de onmacht soms ook om de juiste woorden te vinden voor wat je meemaakt, doet een beroep op de verantwoordelijkheid van alle betrokkenen in het zorgproces.

In de interviews kwam dit onderwerp uitgebreid ter sprake. Opvallend daarbij was, dat zorgverleners over het algemeen vonden dat er 'te weinig werd gesproken'. Als oorzaak hiervan werd genoemd dat verpleegkundigen vaak alleen werken. Men ziet elkaar niet veel en in het maandelijks teamoverleg kan ook niet alles besproken worden, daarvoor is de tijd te beperkt.

In de eerste platformbijeenkomst werden de mogelijkheden en beperkingen van communicatie besproken met het multi-disciplinaire team. Uitspraken over ervaringen op het gebied van communicatie werden van te voren geordend in categorieën en aan de groep voorgelegd. De categorieën waren: communicatie tussen hulpverleners en patiënt, communicatie tussen vrijwilligers, en tussen professionele hulpverleners onderling.

Doel van deze eerste bijeenkomst, die anderhalf uur zou duren, was na te gaan of de uitspraken herkenbaar waren en hoe deze samenhangen met opvattingen over goede zorg. Daarnaast was het de bedoeling na te gaan welke proble- 
men men verder zou willen uitdiepen en verhelderen, om na te denken over beleid, manieren om met dergelijke situaties om te gaan. Dit zowel wat betreft problemen in relatie tot de zorg voor patiënten als in de zorg voor elkaar cq. voor een goed werkklimaat.

In anderhalf uur kan zoveel niet uitputtend besproken worden, daarom zouden na deze meerdere platformbijeenkomsten volgen. Parallel daaraan werd een bijeenkomst georganiseerd voor vrijwilligers in het hospice, waarin ook het onderwerp communicatie ter discussie stond.

De onderwerpen leverden voldoende gespreksstof op. Wat in de bijeenkomst met professionals als probleem naar voren kwam, was niet zozeer dat er te weinig tijd was voor feedback en overleg. Hoewel dit wel werd beaamd, wees men op beperkingen die de praktijk nu eenmaal ook meebrengt, en had men er begrip voor dat het soms hapert aan mogelijkheden tot overleg en reflectie.

Zorgverlener I: In de avonddiensten werken we veel alleen. Ik zou het fijn vinden om daarover eens feedback te krijgen. Een soort klankbord. Dat besproken wordt van "Goh. Hoe doe jij dat?" Ja, dat mis ik wel eens. Je gaat dan naar huis en je bent soms een week weg, maar ergens is dat soms een beetje onbevredigend.

Zorgverlener 2: Ideaal krijg je het nooit, want op het ene moment heeft iemand acuut feedback nodig en dan is het er niet. Dan kun je wel wachten tot het de volgende maand besproken kan worden, maar dan is het niet meer acuut. Dus ideaal kan het nooit worden, dat is onmogelijk.

Zorgverlener 3: Er is wel ruimte binnen de avonddienst of nachtdienst om te overleggen, als je echt iets niet weet of ergens mee zit. Dat je eigenlijk wel verdrietig bent omdat er twee mensen overleden zijn, waar je toch wel...

Je mag natuurlijk altijd bellen, maar ik heb nog nooit beleefd dat mensen dat doen.

Zorgverleners 4 en 5: Dat is onze eigen verantwoordelijkheid ook hè, dat naar buiten brengen. Maar dat hoeft toch niet persé in de werksituatic. Het kan toch prima in je privésituatie.

De beperkte tijd voor feedback en overleg werd in deze groepsbijeenkomst niet als probleem ervaren, mijn interpretatie van individuele interviews over het belang daarvan moest worden bijgesteld. Een probleem waar men het wel over eens was, betreft de ervaring dat communicatie niet altijd op basis van gelijkwaardigheid plaatsvindt. Men ervaart dat beleid dat in het IZO, het wekelijks interdisciplinair zorgoverleg, wordt afgesproken, niet altijd wordt uitgevoerd. Verpleegkundigen hebben de indruk dat het regelmatig gebeurt dat wat zij afspreken wordt overruled door wat de arts wil. 


\subsubsection{De vrijwilligers}

Het platform met de vrijwilligers ging ook over communicatie. Opvallend was dat juist de vrijwilligers zeer tevreden waren over de mogelijkheid van overleg en reflectie.

Ik heb het idee dat er ruimte genoeg is. Ja, ik bedoel niet de ruimte, de letterlijke ruimte, maar de mensen die je kunt benaderen. Die zijn er zoveel bij wie je terecht kunt en die maken daar ook, voor mijn gevoel, tijd voor. Op welk moment je ook komt. Ik bedoel het moet wel heel raar zijn dat het niet uitkomt. Over het algemeen vind ik: als ik ergens mee zit kan ik het me bijna niet indenken dat je hier niet terecht kunt. En dan kun je ook nog kiezen wat je aan wie vertelt. Ja, zo is het toch, bij de een wil je liever dit kwijt en bij dat ander dat.

Er bleken weinig wezenlijke knelpunten te zijn in de communicatie, wat de vrijwilligers betreft. Wat zij graag verbeterd zagen was de eigen verslaglegging: elke vrijwilliger maakt, na afloop van zijn of haar dienst, in het schriftje dat daarvoor is bestemd een verslag Vrijwilligers werken meestal een dagdeel per week in het hospice. Voor de onderlinge communicatie en de overdracht van specifieke dingen die de zorg voor de patiënten betreft is het belangrijk dat na elke dienst een kort verslag wordt geschreven. Dit bleek wel eens te worden overgeslagen omdat men niets bijzonders te melden had. Omdat het schriftje ook een communicatiekanaal is om onderling contact te ervaren, werd dat gevoeld als een gemis. Tijdens het overleg werden afspraken gemaakt erop toe te zien dat de verslaglegging dagelijks plaatsvindt.

De groepsbijeenkomsten leverden geen aanknopingspunten op, brachten geen controversen aan het licht om in volgende bijeenkomsten over door te praten. Met name tijdens de bijeenkomst met professionals kwam het niet tot een echte samenspraak. Deels zal dit zijn veroorzaakt door de manier waarop ik de bijeenkomsten begeleidde, deels ook waren de onderwerpen net niet prikkelend of net niet interessant genoeg. Men liep er gewoon niet warm voor. Hoewel het oorspronkelijk de bedoeling was meerdere platforms te organiseren, werd in samenspraak met de organisatie besloten deze bijeenkomsten op te schorten. Later kregen de groepsbijeenkomsten, op verzoek van management en zorgverleners, een nieuwe invulling in een ethisch beraad dat erop was gericht beleid te ontwikkelen. 


\subsection{Samenvatting}

In dit hoofdstuk werden uitkomsten van een deel van het veldwerk beschreven. De uitgereikte praktijkverhalen bij het begin van het onderzoek leverden bij de respondenten herkenning op. In de reacties op vragen bij deze verhalen werd door zorgverleners gewezen op het recht van de patiënt zelf te beslissen en hem of haar hiertoe steeds voldoende te informeren. Ook relationele aspecten van verbondenheid en verantwoordelijkheid werden genoemd en de spanning waarmee men wordt geconfronteerd wanneer professionele opvattingen en organisatorische regels weerstanden oproepen. Doel van het werken met de praktijkverhalen was, bij het begin van het onderzoek een indruk te krijgen van hoe men problemen definieert en welke normatieve uitgangspunten daarbij een rol spelen.

De interpretatie van de reacties in de interviews leverden een veelkleurig beeld op. Thema's van zowel regelethiek als zorgethiek spelen een rol. Respondenten noemden in de gesprekken steeds het belang van communicatie, openheid, respect en veiligheid. Men signaleert communicatieve onmacht, veroorzaakt door spanning tussen systeemeisen en leefwereldbehoeften. Maar er is ook de bereidheid die gebrekkigheid te accepteren. Minimale voorwaarde is een klimaat waarin men ervaart dat men oog heeft voor elkaar: 'Er is niet altijd genoeg, er is eigenlijk te weinig tijd, maar ik geloof dat wij allemaal de behoefte hebben elkaar te ondersteunen. Alleen al de bereidheid daartoe maakt ons vaardig, ook in korte tijd elkaar eenvoudig het gevoel te geven dat we elkaar dragen, dat we elkaar behulpzaam zijn'. Ethiek als bron voor het denken en handelen, staat regelmatig onder druk van rationele regelsystemen, maar lijkt juist ook door de emoties en existentiële vragen die deze spanning voor betrokkenen met zich meebrengen, een drijvende kracht. Een inzicht dat uit de praktijk, uit de reacties van respondenten komt bovendrijven.

De groepsbijeenkomsten, bedoeld om een samenspraak op gang te brengen naar aanleiding van de reacties van respondenten in de interviews, leverden geen nieuwe inzichten op. In onderling overleg werd besloten de groepsbijeenkomsten een andere inhoud te geven in het later georganiseerde ethisch beraad. Het onderwerp van dit beraad werd door zorgverleners ingebracht als een moeilijke situatie waarop beleid moest worden ontwikkeld (in hoofdstuk 7). 


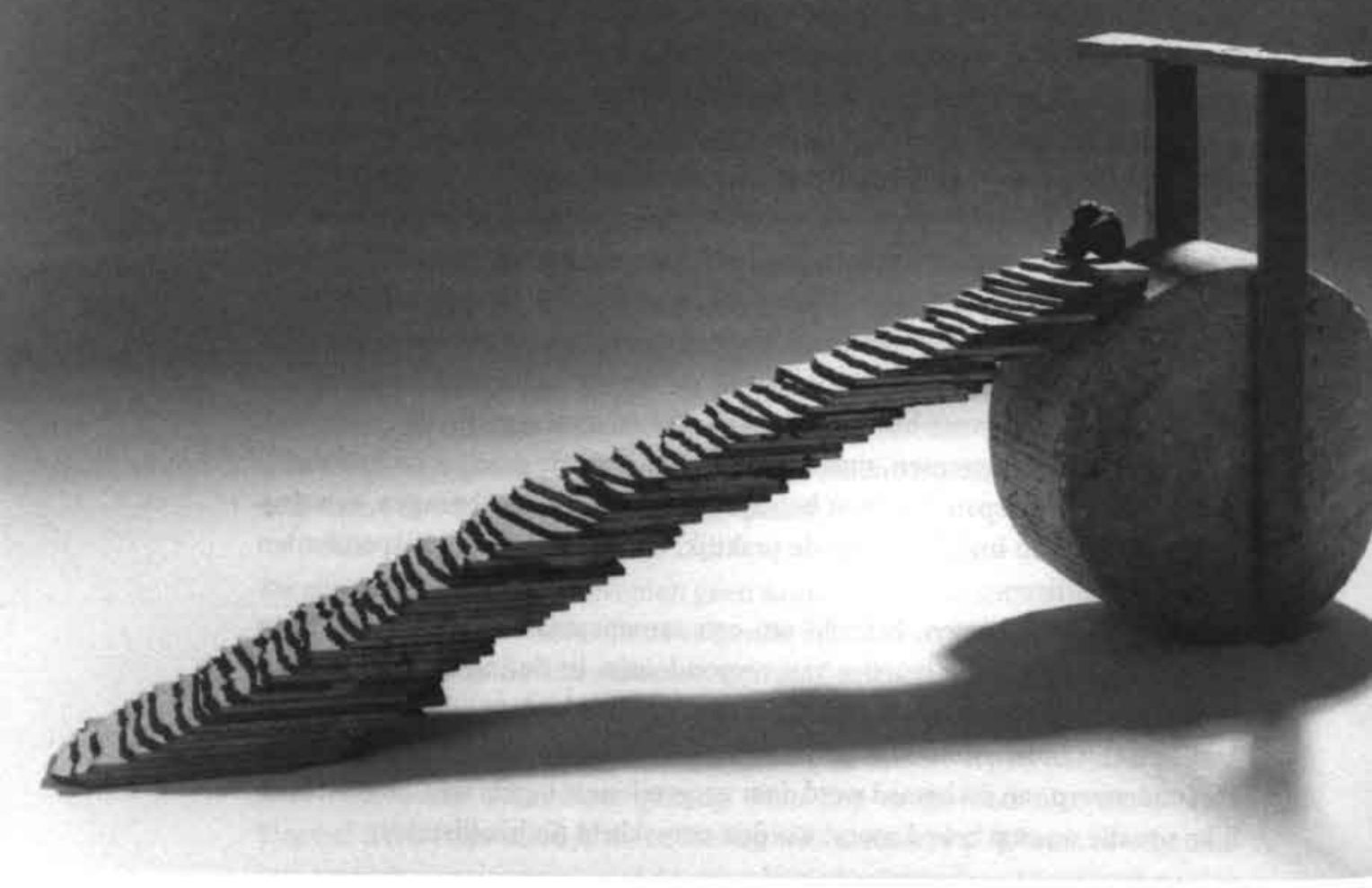




\section{Steenzaam}

Zij heeft de aarde niet gemaakt noch aan de zon het licht gegeven Het uitzicht heeft zij niet gekleurd, maar wat zij aanraakt komt tot leven.

Huil, huil nu wind, schudt wakker al je krachten, ontwaak de kille steen. Hij legt zich neer, maakt zich al klein, wil in haar schoot opnieuw geborgen zijn.

Dan wordt zijn naam in elke steen geschreven, want wat zij aanraakt komt tot leven. 



\section{Integraal Zorg Overleg als vorm van moreel beraad}

\subsection{Inleiding}

Voor het bewaren en verder ontwikkelen van de eigenheid van palliatieve zorgverlening is aandacht voor ethiek onontbeerlijk. Tegelijk kan ethiek moeilijk zijn en spanning opleveren. Systeemdruk met zijn regels, protocollen en rationele benadering van leefwereldbehoeften en emoties die zorgverleners signaleren bij patiënten en bij zichzelf, veroorzaakt communicatieve onmacht, frustratie en ook angst. Spanning die herkenbaar is in concrete situaties waarover zorgverleners in de interviews en in reactie op de praktijkverhalen vertellen, en waarin de regelethische oplossingen worden gevonden op zorgethische vragen zoals die rond 'het verkeerde bed'. Spanning is ook herkenbaar in situaties waarover men zegt te weinig privacy voor patiënten te kunnen creëren of dat men er soms moeite mee heeft moeilijke ervaringen of vragen in een teamoverleg naar voren te brengen omdat men zich onzeker, niet veilig of niet serieus genomen voelt. De behoefte aan een klimaat waarin voldoende mogelijkheden aanwezig zijn en aandacht is voor communicatie en reflectie klonk door in de interviews en in de reacties op de praktijkverhalen.

Communicatie en reflectie bieden mogelijkheden om ethiek in de praktijk vorm te geven. Overigens is de vruchtbaarheid van overleg mede afhankelijk van de kwaliteit van het communicatieve klimaat van de instelling. Eén van de mogelijke overlegvormen die ruimte bieden aan ethische vragen is een regelmatig terugkerend moreel beraad. Verkerk (2000) pleit hiervoor. Verkerk en ook Walker (1998) zien zorginstellingen als verantwoordelijkheidspraktijken, waarin de kwetsbaarheid van individuen - van patiënten maar ook van zorgverleners - aan het licht komt. De vraag daarbij is in hoeverre zorgorganisaties en zorgverleners dit inzicht delen en welke aandacht er voor is. Morele problemen zijn altijd verbonden met het perspectief van degene die ze als zodanig herkent en aan de orde stelt: 'Verpleegkundigen zien vaak andere morele dimensies dan dokters en op hun beurt zien managers de morele werkelijkheid ook weer anders'(Verkerk, 2000 p. II5). 
Dit hoofdstuk gaat over het wekelijks Integraal Zorg Overleg (IZO). Tijdens het veldwerk in de periode september - december 1999 en vanaf maart tot september 2000 , werd dit overleg wekelijks bijgewoond. In het IZO staan zorgverleners van alle betrokken disciplines stil bij de verschillende aspecten van zorg voor de patiënten die in het hospice zijn opgenomen of op de wachtlijst staan. Problemen of aspecten die extra aandacht nodig hebben, worden door hen in het multidisciplinair overleg ingebracht en toegelicht. Op het gebied van ethiek bestond bij het management behoefte aan verheldering. Hebben we voldoende oog voor ethische problemen die het werk met zich meebrengt? Hoe komt onze besluitvorming eigenlijk tot stand? Met andere woorden: 'Biedt het IZO voldoende ruimte voor ethische vragen in de vorm van een moreel beraad dat is geintegreerd in dit wekelijkse patiëntenoverleg?' Dit waren vragen die ik meenam voor het bijwonen van deze bijeenkomsten. Vragen die pasten bij het doel van het onderzoek, om in gesprek te raken met betrokkenen om inzicht te krijgen in deze palliatieve zorgpraktijk en de problemen die men daarin tegenkomt. Ethiek was niet alleen een aandachtspunt van het management. Ook zorgverleners lieten zich horen over ethiek en de behoefte aan reflectie op ethische problemen.

Waar in het vorig hoofdstuk zorgverleners aan het woord komen in interviews en in reacties op de aan hen voorgelegde praktijkverhalen, gaat het initiatief in dit hoofdstuk meer van henzelf uit en gaat het niet enkel om wat men zegt, maar ook om de besluitvorming en het handelen in ethische moeilijke situaties.

\subsection{Integraal Zorg Overleg}

Het Integraal Zorg Overleg (IZO) is een multidisciplinair overleg, dat wekelijks plaatsvindt. Doel van het overleg is het afstemmen en bewaken van de interdisciplinaire zorgverlening ten bate van het verbeteren c.q. stabiliseren van het lichamelijk, geestelijk en sociaal welzijn van de individuele patiënt(en). Dit gebeurt in het overleg aan de hand van de observaties en ervaringen van de zorgverleners, die vanuit verschillende disciplines bij de zorg bestrokken zijn, én aan de hand van signalen van patiënten en naasten. Hier vindt reflectie plaats op de dagelijkse praktijk en de problemen die zich voordoen, aan de hand van eerdere afspraken. Het overleg wordt voorgezeten door het hoofd van de zorg. Aanwezige zorgverleners wisselen ervaringen uit en geven vanuit hun specifieke deskundigheid hun mening over het te volgen beleid. Om tot voldoende uitwisseling te kunnen komen is het de bedoeling dat bij dit wekelijks overleg steeds de die dag dienstdoende zorgverleners aanwezig zijn: verpleegkundigen en arts(en), de fysiotherapeut, de pastoraal werker, de zorgverlener 
belast met de zorg voor de naasten (ook nazorg) en de medisch directeur. Daarnaast kunnen derden, zoals huisarts, maatschappelijk werker, of andere disciplines aan het overleg deelnemen wanneer dat wenselijk wordt geacht. Doordat zorgverleners in roulerende diensten aanwezig zijn in het hospice, laat ook de aanwezigheid van zorgverleners in het IZO-overleg een wisselend patroon zien. De 'zorgverlener naasten' bijvoorbeeld, bleek nooit op donderdag te werken, waardoor haar inbreng in het overleg steeds schriftelijk was en terugkoppeling de volgende werkdag plaatsvond.

In het zorgdossier ${ }^{9}$ wordt nieuw afgesproken beleid schriftelijk vastgelegd, zodat zorgverleners die niet aanwezig zijn, goed geïnformeerd blijven. Ook worden afspraken en veranderingen in beleid of medicatie zoveel mogelijk met patiënten en familie (of contactpersoon) doorgesproken.

Het overleg heeft een vast patroon. Aan de orde komen:

- Bespreken van de nieuwe opnamen, schets van de situatie en doelstelling van het verblijf, zorgplan.

- Bespreken van reeds opgenomen patiënten: aan de hand van de belangrijkste (zorg)problemen op het gebied van lichamelijke klachten, emotionele en geestelijke problemen (ook de familie van de patiënt wordt in de zorg betrokken) en levensbeschouwelijke vragen.

- De patiënten die zijn ontslagen of die zijn overleden met rapportage van hoe het is verlopen.

- Planning van nieuwe opnamen.

Het overleg neemt één tot anderhalf uur in beslag, waarbij de situaties van de in het hospice verblijvende patiënten wordt besproken. Meestal gaat het om acht, soms negen patiënten, een enkele keer minder dan acht. Daarnaast is er tijd nodig om over de planning van op te nemen patiënten te praten.

Om een zo goed mogelijk inzicht te krijgen van hoe het overleg verliep en welke plaats ethiek erin had, besloot ik een matrix te maken waarin soorten aandachtspunten en problemen, door wie (welke disciplines) deze werden genoemd en wie deelnamen aan de discussie en besluitvorming konden worden opgenomen. Langs de $\mathrm{x}$ - en de $\mathrm{y}$-as werden de verschillende gebieden (fysiek, sociaal, psychisch, ethisch, spiritueel) aangegeven en een overzicht gegeven vanuit welke disciplines men deelnam aan het overleg. Zo geeft de

9 Een zorgdossier is het dossier van de betreffende patiênt waarin alle relevante medische informatie is vastgelegd, tevens achtergrond informatie over de patiênt, zijn/haar familiege. schiedenis kortom alle informatie die van belang is voor het organiseren van de zorg. Dagelijks wordt dit dossier door middel van een zogenoemde dagrapportage bijgewerkt door de dienstdoende verpleegkundige. 
ingevulde matrix per bijeenkomst een beeld van meest besproken onderwerpen en wie per onderwerp een inbreng hadden. Daarnaast werd van elke bijeenkomst een verslag geschreven en beschikbaar gesteld aan het hoofd zorgverlening, de voorzitter van het IZO.

In het vervolg van dit hoofdstuk wordt beschreven welke ethische probleemsituaties aan de orde kwamen in het overleg. Daarbij zal ik ook ingaan op het proces van besluitvorming en de opvolging daarvan. Vragen die een rol spelen zijn:, Welke rol speelde reflectie, hoe verliep de communicatie? Wie nam steeds het initiatief tot bespreken van het probleem en tot besluitvorming? Ook zal ik stilstaan bij de rol die ik als onderzoeker zelf speelde in dat proces.

\subsection{Plaats van ethiek in het overleg}

De bijeenkomsten zijn zo gestructureerd, dat steeds per patiënt een korte uiteenzetting wordt gegeven van de (ziekte)geschiedenis en huidige stand van zaken per patiënt. Een werkwijze die ruimte creëert voor het delen van ervaringen aan de hand van concrete casuīstiek. Een belangrijke voorwaarde voor ethische reflectie en gemeenschappelijke zingeving (Nussbaum, 1998, p.r8). Vervolgens wisselen artsen, verpleegkundigen en andere aanwezige disciplines observaties uit, aan de hand waarvan het beleid wordt voortgezet, dan wel wordt aangepast. Per discipline wordt gereflecteerd op gesignaleerde problemen en worden suggesties gedaan om ermee om te gaan. Dit resulteert regelmatig in verschillen van mening over de interpretatie van geschetste situaties. Verpleegkundigen leggen vaker de nadruk op belevingsaspecten voor patiënt en familie, terwijl artsen vaker de medische-en psychologische achtergronden toelichten. De benadering van ethische problemen is weinig systematisch. Hoewel het management aangaf dat de ethische dimensie van het werk door mijn aanwezigheid in het overleg meer aandacht kreeg, kreeg ik daarvoor in mijn waarneming geen concrete aanwijzingen. Er was geen materiaal om te vergelijken hoe het was voor mijn komst. Tijdens het overleg kreeg ik de indruk dat de aandacht voor (ethische) vragen en de criteria die de doorslag gaven, veel meer afhankelijk waren van de aanwezige teamleden en de signalen die door hen werden opgevangen van patiënten en familie. Ook wie het initiatief neemt om problemen op ethisch terrein aan de orde te stellen, verschilt per situatie. Volgens het stramien waarop het overleg plaatsvindt, is een van de eerste aandachtspunten bij elke patiënt de algemene lichamelijke toestand en eventuele klachten of problemen. De afspraken uit het vorige overleg zijn een richtlijn voor de status ervan. De eerste aanzet wordt steeds gedaan voor de voorzitter, het hoofd zorgverlening. Hierna geeft de verpleegkundige die de betreffende 
patiënt die dag(en) verzorgt een overzicht van de situatie en aandachtspunten. Medische aandachtspunten vormen de hoofdzaak, waarbij het vaak gaat over bijstellen of instellen van adequate medicatie ter bestrijding van klachten of ongemak. Dit deel van het gesprek gaat meestal tussen arts en verpleegkundige. Ook de fysiotherapeut heeft hierin een aandeel. Daarna volgen sociale en psychische aspecten en spiritualiteit (levensbeschouwelijke vragen en vragen over zingeving). Deze niet scherp van elkaar af te grenzen levensgebieden zijn van invloed op het welbevinden (ook lichamelijk) van de patiënt en zijn directe naasten. De voorzitter noemt de aandachtsgebieden en vraagt of er problemen zijn die extra aandacht vragen. Het zijn aspecten waarover niet alleen artsen en verpleegkundigen aan het woord zijn. Ook de pastor/directeur en de fysiotherapeut nemen deel aan het gesprek en de besluitvorming. Door de dagelijkse verzorging en observatie van patiënten, de vele contacten en gesprekken zijn verpleegkundigen nauw betrokken. Niet alleen bij hoe het lichamelijk met hen gaat maar vooral ook hoe zij hun ziekte ervaren en kunnen omgaan met het naderend levenseinde. Ethisch moeilijke situaties worden, als daar aanleiding toe is, steeds spontaan door hen of door de arts ingebracht. In de discussie zijn zij de belangrijkste gesprekspartners. In hun functioneren in de praktijk worden zij wellicht het meest geconfronteerd met ethische vragen. De arts stelt vaker medisch-ethische vragen als 'Wat te doen bij een volgende koortspiek: wel of niet behandelen?' Verpleegkundigen brengen meer zorgethische vragen in zoals over het effect van behandeling op kwaliteit van leven. De voorzitter (ook verpleegkundige) neemt ook aan het ethisch overleg deel, maar meer in haar rol als voorzitter. Als situaties bijzonder moeilijk zijn en eigenlijk alle zorgverleners over een langere periode raken, vertaalt zich dat in een actieve deelname van alle aanwezigen in het overleg.

De teamleden in het overleg hebben een verschillende rol. Vanuit de disciplines en functies die zij vertegenwoordigen en van waaruit zij betrokken zijn bij de patiëntenzorg, verschilt ook het perspectief van hun observaties. De gezamenlijke inbreng is van belang om de besproken zorgsituaties zo goed mogelijk te kunnen inschatten en in te spelen op de behoeften van patiënten. McClelland en Sands (1993) hebben onderzoek gedaan naar consequenties van de afwezigheid in een team van één van de disciplines. $\mathrm{Zij}$ zagen dat bij afwezigheid van één van de teamleden die een bepaalde discipline vertegenwoordigt, een van de andere teamleden zijn of haar rol overnam. Zoals in het IZO ook bij afwezigheid van bijvoorbeeld het hoofd zorg, de voorzittersrol werd overgenomen door de pastor, cq. zakelijk directeur. Of bij afwezigheid van de eerst verantwoordelijke arts, zijn waarnemer(ster) zijn plaats innam. Het ging in die gevallen om afwezigheid die tijdelijk was, door vakantie en dergelijke. McClelland en Sands doelen echter op de structurele afwezigheid van 
één van de disciplines. Ook dan wordt die rol door een van de andere teamleden overgenomen. Zo kon de zorgverlener naasten nooit bij het overleg aanwezig zijn. De pastor en dienstdoende verpleegkundigen namen haar rol over. Leemtes die men ervaarde door haar afwezigheid, met name als het ging om ethische moeilijke situaties, werden opgevangen door overleg achteraf wanneer de zorgverlener weer aanwezig was. McClelland en Sands waarschuwen voor een dergelijke situatie. De aanwezigheid en de stem van elke discipline is belangrijk, vooral als professionele gebieden elkaar overlappen. Door die overlappende kennis wordt de afwezigheid vaak niet als een gemis ervaren. De mogelijkheid iemand achteraf alsnog te kunnen consulteren lijkt een veilige buffer. Maar het gaat volgens McCLelland en Sands juist om de persoonlijke inbreng: 'In order for a team to recognise that a perspective is excluded, the discipline must be present' (1993, p. 88).

Interessant is in dat opzicht de rol van pastor, cq. zakelijk directeur. Beide functies verenigd in één persoon, die zelf regelmatig waarschuwde 'met twee petten op te zitten'. Beide disciplines zijn vertegenwoordigd en aanwezig in het overleg, maar spreken met één stem.

\subsection{Ethische problemen}

Hoewel niet systematisch, worden in de meeste bijeenkomsten toch wel een of meerdere ethische vragen gesteld. In slechts zes van de zesentwintig bijgewoonde IZO's was ethiek geen onderwerp. De situaties die het meest werden genoemd, heb ik geordend naar thema en naar de in het geding zijnde zorgethische- dan wel regelethische uitgangspunten.

\subsubsection{Verantwoordelijkheid voor kwaliteit van leven}

Morele problemen onderscheiden zich van andere problemen door de claim die er van uitgaat, het beroep op verantwoordelijkheid tegenover zichzelf en anderen (Nussbaum, 1986, p. 29). Verantwoordelijkheid kan worden opgevat als plicht (regelethiek), maar ook als uitdrukking van zorg voor zichzelf en anderen (Tronto, 1993). In een samenleving waar de medische mogelijkheden zo groot zijn dat mensen met agressieve en ongeneeslijke aandoeningen steeds langer in leven kunnen blijven, worden zorgverleners en patiënten steeds meer geconfronteerd met het effect van die behandelingsmogelijkheden op de kwaliteit van het leven. Voorbeelden uit het hospice van dilemma's die hiermee samenhangen: 
Mevrouw Appelman wordt vanuit het hospice regelmatig naar het ziekenhuis gebracht voor bestraling. Verpleegkundigen wijzen er op dat dit te belastend is voor mevrouw, de behandeling leidt niet tot verlichting van de klachten. Zij stellen de vraag of dit nog wel palliatieve behandeling mag heten.

Over patiēnte IJzendoorn met haar schildklierproblematiek: 'Doorzetten van de behandeling leidt tot de dood, stoppen van de behandeling tot slechte kwaliteit van leven.'

De heer Van Ommeren heeft zich duidelijk uitgesproken, hij wil geen levensverlengende behandeling. Omdat hij slecht kan slikken is eerder al een infuus aangebracht waardoor hij vocht krijgt toegediend. Dit infuus blijkt nu een levenslijn' voor hem te zijn. Verpleegkundigen vragen zich af: 'Wat doen we als het infuus 'sneuvelt'?'

Heer Zomers heeft regelmatig terugkerende blaasontstekingen. Zijn levenskwaliteit is slecht, de levensverwachting kort. De dienstdoende arts legt de vraag voor: 'Wat te doen als hij in het weekend weer een koortspiek krijgt: wel of niet behandelen met antibiotica?'

De verantwoordelijkheid van zorgverleners voor goede zorg en het resultaat van die zorg op de kwaliteit van leven, wordt door alle disciplines onderschreven. Behandeling van de arts, waar overige zorgverleners vraagtekens bij zetten vanwege de nadelige effecten, worden in het gezamenlijk overleg becommentarieerd. De arts beargumenteert vanuit zijn deskundigheid het waarom van de behandeling, terwijl andere disciplines voor de patiënt in de bres lijken te springen door op de effecten, de belasting er van te wijzen.

Mevrouw Appelman, een patiënte die al langer in het hospice verblijft, is weduwe en heeft geen kinderen. Een bevriend echtpaar bezoekt haar regelmatig. Mevrouw lijdt aan longkanker met uitzaaiingen waardoor ze pijn heeft, vooral in de heup. Mevrouw is altijd zeer zelfstandig geweest, voelt zich nu afhankelijk. Ze heeft heimwee naar huis en is licht verward. Voor de pijn in haar heup is behandeling in het ziekenhuis afgesproken: een serie van zes bestralingen. Verpleegkundigen vragen zich af of dit de kwaliteit van haar leven verbetert. Het vervoer en al het ongemak dat daar voor haar aan vastzit en de klachten van de bestraling wegen volgens hen niet op tegen het door artsen verwachte resultaat.

Verpleegkundige over mevrouw Appelmans: 'Waarom zoveel en op die plaats bestralen?' 
Arts: 'Om grotere, onhoudbare problemen te voorkomen (...)medicijnen kunnen niet verhoogd worden, omdat dat grote kans geeft op een delirium.' Een week later, de verpleegkundige: 'De klachten worden niet minder, mevrouw is suffer en de pijn neemt niet af. Wel heeft zij veel last van de bestraling. De (waarnemend) arts neemt daarop contact op met de radioloog en behandelend arts, waarna de bestralingen worden stopgezet en medicatie wordt aangepast.

Mevrouw IJzendoorn, alleenstaande weduwe, verkeert in een ver gevorderd stadium van kanker met vele uitzaaiingen. De schildklier is aangetast. Mevrouw is meer en meer verward en maakt vaak een depressieve indruk. Arts over behandeling van mevrouw. 'De schildklierafwijking laat zich niet goed behandelen, terwijl niet behandelen leidt tot Alzheimer-achtige klachten: toch doorzetten van behandeling leidt tot de dood, stoppen tot slechte kwaliteit van leven.' Verpleegkundigen nuanceren de situatie, wijzen op alternatieven: 'Mevrouw is niet altijd depressief, ze heeft prikkels nodig, reageert daar goed op.'

Besloten wordt extra aandacht te geven door vrijwilligers en andere zorgverleners, zorgen dat ze niet te veel alleen is. Het gesprek over de situatie van mevrouw IJzendoorn resulteert in afspraken over ondersteuning van sociale-en psychologische begeleiding, met te verwachten gunstig effect op de levenskwaliteit.

De situatie van mijnheer Van Ommeren wordt door de verpleegkundige ingebracht. Het gaat om angst: 'Mijnheer is bang voor de levensverlengende effecten van behandelingen die hem mogelijk nog worden aangeboden. Dat effect wil hij niet. Tegelijk vertegenwoordigt het infuus voor hem de 'levenslijn en is hij bang dat hij zal sterven als het infuus wordt gestopt.'

De realiteit is dat infusen op den duur 'sneuvelen', de insteekopening kan gaan ontsteken, waardoor het infuus moet worden verwijderd om eventueel opnieuw op een andere plaatst te worden ingebracht. De toediening van vocht per infuus heeft een levensverlengend effect. Waardoor de verpleegkundige de vraag stelt: 'Wat te doen als het infuus sneuvelt? Is daarover met de patiënt gesproken?' De arts spreekt af dat hij met de heer Van Ommeren zal spreken en zijn wens ten aanzien van het infuus in het dossier zal vermelden. Hierbij maakt de tweede arts de kanttekening, dat wanneer de patiēnt de dingen die gebeuren en mogelijke behandelingen die worden voorgesteld beter uitgelegd krijgt, de wens ten aanzien van de levensverlengende effecten genuanceerder ligt dan uitsluitend: niets nieuws proberen.

Men spreekt af een gesprek met de heer Van Ommeren te voeren over zijn angsten. Als het infuus dan daadwerkelijk sneuvelt, zal opnieuw met hem worden gesproken over de te nemen stappen. 
De heer Zomers bereidt zich voor op zijn sterven. Hij heeft afscheid genomen van mensen en dingen. De terugkerende ontstekingen zijn tot nu steeds behandeld met antibiotica. De arts stelt in het overleg de vraag: 'Wat te doen als hij in het weekend opnieuw een koortspiek krijgt? Welke instructie achter te laten voor de arts die in het weekend waarneemt?' Zij stelt voor, dit probleem met de patiënt zelf te bespreken en aan de hand van de uitkomst van dat gesprek beleid vast te stellen. In het overleg van de volgende week rapporteert de arts, dat bij ontstaan nieuwe koortsaanval geen antibiotica gegeven zal worden. Dit is de wens van de heer Zomers.

Het bespreken van deze ethische problemen leverde soms veel en soms heel weinig reflectie en discussie op in het overleg. In het geval van de heer Zomers is het de arts die het probleem aan ziet komen, en stappen onderneemt om een strategie af te spreken. Andere teamleden die deelnemen aan het overleg, dragen niet bij aan besluitvorming of verheldering van deze situatie. Dat is anders in het geval van mevrouw Appelman en mevrouw IJzendoorn. Daar nemen verpleegkundigen actief deel aan de discussie, en springen zij in de bres voor de patiënten. Vanuit ethisch theoretische gezichtspunten kan dit worden geînterpreteerd als onderscheid in regelethische en zorgethische benadering. In de situaties van mevrouw Appelman en mevrouw I]zendoorn gaat het met name om de zorg voor de kwaliteit van leven. Verpleegkundigen reflecteren op door artsen ingezet beleid, dat voor de betreffende patiënten belastend is en geen verlichting van het lijden oplevert. Door hun dagelijkse, vaak intensieve zorg voor patiënten, hebben zij meer zicht op de effecten van de behandeling en staan zij dicht bij de beleving van patiënten. Door hun relationele verbondenheid en deskundigheid als zorgverlener voelen zij zich verantwoordelijk om voor deze patiënten in de bres te springen en brengen zij argumenten naar voren om het beleid om te buigen en meer in overeenstemming te brengen met de grondbeginselen van de palliatieve zorg: verzachting van het lijden en zoveel mogelijk de kwaliteit bewaren van het leven dat nog rest. In de situatie van de heer Zomers en de heer van Ommeren gaat het om de autonomie van de patiënt, als recht op zelfbeschikking. Een regelethisch uitgangspunt, dat een beroep doet op de verantwoordelijkheid om afspraken te maken over wel of niet medisch ingrijpen in acute situaties. Blijft de vraag waarom minder reflectie plaatsvindt, waarom andere teamleden minder deelnemen aan het overleg als het gaat over de situatie van de heer Zomers. Ook in de regelethiek is communicatie belangrijk om tot een juiste afweging van in het geding zijnde principes te komen. Wellicht weegt het regelethische principe van autonomie zo zwaar voor zorgverleners, dat het alleen al daardoor minder uitnodigt tot kritische reflectie. 


\subsubsection{Autonomie van de patiēnt en aandacht voor de zorgbe. hoefte}

Ethische vragen zijn verbonden met opvattingen over wat goed is. Een van de in het hospice geldende criteria daarbij is dat de autonomie van de patiënt zoveel mogelijk gerespecteerd dient te worden. Opvattingen van wat goede zorg is kunnen uiteenlopen, soms heeft de patiënt daarover andere ideeën dan de zorgverleners. Een aantal van de problemen op dit gebied, die tijdens het overleg werden ingebracht:

Mevrouw Bellenbos is boos over het besluit haar over te plaatsen naar het verpleeghuis. $\mathrm{Ze}$ is sinds zes weken in het hospice en heeft 'op aanraden van de arts' haar huis verkocht. Zij heeft nu geen keus meer, geen plek om naar terug te gaan.

De heer Mijnders is met spoed in het hospice opgenomen. Om plaats te maken, was een interne verhuizing van patiënten nodig. Deze eerder opgenomen patiënten vinden dat vervelend en doen hun beklag daarover aan verpleeg. kundigen. Tijdens het overleg worden vraagtekens gezet bij het spoedeisende karakter van deze opname.

Mevrouw Rienstra wil niet meer leven. Zij heeft geen specifieke klachten, maar verder leven heeft voor haar geen zin meer. Haar man verzet zich tegen euthanasie.

Respect voor autonomie vraagt van zorgverleners dat zij zich verdiepen in de opvattingen ten aanzien van dat begrip, zowel bij patiënten als bij zichzelf en andere zorgverleners. Om te kunnen begrijpen hoe iemand anders, een patiënt, een collega-zorgverlener, de werkelijkheid benadert, welke waarden en normen daarbij belangrijk zijn, of welke concepten van kwaliteit, autonomie, moraliteit daarin een rol spelen, moet men de eigen opvattingen en ideeën in het spel brengen (hoofdstuk 3, Communicatie en reflectie).

Mevrouw Bellenbos is volgens de verpleegkundige die het probleem inbrengt, terecht boos. De arts heeft de eventuele overplaatsing naar een verpleeghuis wel met haar zoon besproken, maar niet met haar zelf: 'Zij voelt zich bekocht.' De arts verwacht dat de verpleeghuisomgeving beter is voor mevrouw. Terugkijkend op de gang van zaken, wordt de procedure die is bewandeld betreurd. Een gesprek met mevrouw zal alsnog plaats hebben. Daarbij zal men ook ingaan op haar verwijt dat het voor haar onbegrijpelijk is dat zij maar zes weken in het 
hospice mag blijven, tenwijl sommige andere mensen er veel langer zijn. Twee weken later verhuist mevrouw Bellenbos naar het verpleeghuis, het is duidelijk niet haar keus, maar ze heeft zich in haar lot geschikt. In het verpleeghuis blijft ze de eerste week op haar kamer. Later kan ze beter omgaan met de situatie en legt ze nieuwe contacten. Tijdens het overleg wordt afgesproken dat in de toekomst de afspraken over beleid ten aanzien van verblijf en mogelijke overplaat. sing naar een verpleeghuis schriftelijk worden vastgelegd.

Samenhangend met het probleem van mevrouw Bellenbos werden regelmatig tijdens het overleg vragen gesteld ten aanzien van het opnamebeleid. Met name het spoedeisende karakter van bepaalde opnamen werd betwist. Temeer daar door zo'n opname mensen die al in het hospice verblijven soms tegen hun wil en belang in, naar een andere kamer moeten verhuizen.

Dat was het geval toen de heer Mijnders met bronchuscarcinoom, plotseling werd opgenomen: Thuis ging het niet meer, de mantelzorg kon het niet meer aan en mijnheer voelde zich onveilig. Verpleegkundigen stellen de vraag: 'Waarom was hier sprake van spoed?' Om de heer Mijnders een goede plek te bieden, moesten twee patiēnten (onder protest) naar een andere kamer verhuizen. Bij opname bleek de situatie van de heer Mijnders stabiel, verpleegkundigen signaleren geen angst. Zij springen in de bres voor de eerder opgenomen patiënten en verlangen meer inspraak bij de planning van opnamen. Hiertegen brengt de arts in dat het in zulke gevallen toch vaak gaat om crisissituaties. In de thuissituatie lijkt de toestand onhoudbaar, eenmaal opgenomen komt de patiënt tot rust, de omgeving is overzichtelijk, hij voelt zich veilig en de angst verdwijnt. De inspraak bij de planning van nieuwe opnamen zou volgens de verpleegkundigen pas optimaal kunnen functioneren wanneer de arts bij de thuisbezoeken vergezeld wordt door een van hen. Dit stuit echter op budgettaire problemen.

Mevrouw Rienstra verblijft sinds een week in het hospice. Ze is opgenomen voor terminale zorg. De zorg is complex door de vele lichamelijk problemen, zoals benauwdheid, vermoeidheid, doorligwonden en vochtophoping in de buik. De dienstdoende verpleegkundige meldt in het overleg dat mevrouw met haar gesproken heeft over haar euthanasiewens: 'Mevrouw is op, zij kan niet meer. De situatie is op dit moment stabiel er zijn geen specifieke klachten, maar ver. der leven is te zwaar. Haar echtgenoot verzet zich echter hevig tegen het idee van actieve levensbeëindiging.'

Er vindt uitwisseling van ervaringen en deskundigheid plaats. Ook de arts is op de hoogte van de wens van mevrouw Rienstra en heeft daarover verschillende 
keren met haar gesproken: 'Haar wens is het gevolg van 'burn-out', mevrouw is niet depressief. Ze envaart geen zingeving meer van het bestaan.' De echtgenoot en ook de dochter van mevrouw heeft problemen met de vraag naar euthanasie. De arts heeft met hen een gesprek gehad over de mogelijkheid van terminale sedatic. Euthanasie wordt in het hospice niet toegepast. Een opvatting die niet alleen verbonden is met de christelijke identiteit van de instelling maar een opvatting die breed gedragen wordt in de wereld van de palliatieve zorgverlening: 'It is remarkable that most people working in the area of palliative care are firmly opposed to euthanasia' (Janssens, 2001, p. 142). Patiënten en familie zijn hiervan doorgaans op de hoogte. Wel kunnen patiēnten die aan hun wens vasthouden, worden doorvenwezen en overgeplaatst. In de situatie van mevrouw Rienstra stelt de arts voor om door toediening van medicatie mevrouw in een slaaptoestand te brengen (terminale sedatie) tot aan het overlijden. Echter ook deze mogelijkheid is voor echtgenoot en dochter problema. tisch.

$\mathrm{Na}$ uitvoerig overleg wordt besloten dat de arts samen met een verpleegkundige opnieuw het gesprek aangaat met mevrouw om over verhoging van de medica. tie (sedatie) te praten. Dit in aanwezigheid van haar man en haar dochter. Ook zal overleg plaatsvinden met de 'zorgverlener naasten' over begeleiding van de echtgenoot en dochter. In de daarop volgende week is mevrouw Rienstra overleden. Zij kreeg slaapmedicatie en morfine voor de pijn, de euthanasiewens werd niet meer geuit. $\mathrm{Ze}$ is rustig overleden.

Voor de familie was het zo goed gegaan.

Opvallend in de bespreking van de bovengenoemde situaties was dat steeds een balans werd gezocht tussen autonomie van de patiënt en de verantwoordelijkheid van zorgverleners om de zorg af te stemmen op de zorgbehoefte die zij in het omgaan met de patiënten en hun naasten signaleren. In de situaties van mevrouw Bellenbos en de heer Mijnders was het heel moeilijk om dat evenwicht te vinden. Mevrouw Bellenbos voelt zich bekocht en in de situatie van de heer Mijnders zijn het de eerder opgenomen patiënten die moeten inleveren. Beide situaties leverden veel discussie op waarin verpleegkundigen het beleid kritisch tegen het licht hielden. Zo ook in de situatie van mevrouw Rienstra. In die situatie wordt getracht op communicatieve wijze, in gesprek met zowel zorgverleners als patiënt en familie met de situatie om te gaan. Over deze aanpak bestaat binnen het team consensus.

Autonomie wordt in de geschetste situaties breed opgevat, enerzijds gaat het om de door patiënten en naasten geuite wensen, zoals in het geval van mevrouw Bellenbos die niet naar het verpleeghuis wil, maar ook om zingeving 
zoals bij mevrouw Rienstra en haar familie. Reflectie vindt plaats door zowel inbreng van de gevoelens van patiënten als de opvattingen van de zorgverleners zelf. In het geval van mevrouw Bellenbos en ook bij de heer Mijnders wordt gezocht naar een compromis op basis van de mogelijkheden die er zijn. Mevrouw Bellenbos schikt zich weliswaar in haar 'lot', maar de situatie leidt wel tot kritische reflectie op beleid ten aanzien van de duur van verblijf in het hospice en eventuele overplaatsing. Wat de spoedopname betreft, betekent het compromis dat optimale inbreng van andere zorgverleners beperkingen heeft. De doorslag in de beoordeling van de situatie spoed of niet-spoed, blijft de verantwoordelijkheid van de arts. Er is sprake van spanning door de beperkte inbreng van de visie van verpleegkundigen in wat betreft de planning en beleid van opnamen en van overplaatsen. Zorgethische argumenten van met name verpleegkundigen hebben de overhand in het communicatief overleg, zij laten de stem van de patiënt horen, wijzen op onnodige belasting van behandeling en kwaliteit van leven. Oplossingen waartoe het overleg leidt zijn regelethisch waar het betreft de planning van opnamen en eventuele overplaatsing (de heer Mijnders, mevrouw Bellenbos, het zijn de regels die hier de doorslag geven), in andere gevallen zoals bij mevrouw Appelman en mevrouw IJzendoorn wordt opnieuw afgestemd met de patiënte (bij monde van verpleegkundigen) en wordt het beleid bijgesteld zodat het meer bijdraagt aan de kwaliteit van leven. In de situaties van mijnheer Zomers en mevrouw Rienstra wordt ook het gesprek met patiënten en familie aangegaan. Er vinden gesprekken plaats op basis van regelethische principes van weldoen, niet schaden en autonomie als recht op zelfbeschikking. Patiënten beslissen op basis van informatie die de artsen verstrekken over (ethische)problemen die zij voorzien.

\subsection{Hermeneutiek in praktijk}

Sommige van de discussies over ethische problemen die tijdens het overleg plaatsvinden zijn voorbeelden van een communicatief, hermeneutisch proces. Tegelijk kan worden geconstateerd dat in een aantal gevallen weinig reflectie plaatsvindt en besluiten eenzijdig tot stand komen. Verscheidene factoren spelen een rol. De beschikbaarheid van verschillende perspectieven bijvoorbeeld (verbonden met de aanwezigheid van de disciplines waaruit het team bestaat) in relatie tot de patiënt waarom het gaat. Een 'stem' die niet aanwezig is, wordt niet gehoord (McClelland, Sands, 1993). De complexiteit van de situatie speelt ook een rol. In situaties waarin de arts maatregelen wil afspreken voor het geval in het weekend (bij zijn/haar afwezigheid) een besluit moet worden genomen over wel of niet behandelen van opnieuw een koortsaanval, is 
besluitvorming meestal snel en eenduidig. In andere situaties, waar het gaat om onduidelijkheid over de (zorg)behoeften van een patiënt, of over het beschermen van privacy, over familierelaties, of de impact van medicatie op de levenskwaliteit van de betreffende patiënt, zijn discussies intensiever. Ze komen in volgende IZO's terug, en er worden meer perspectieven ingebracht. Ethische problemen die een sterk beroep doen op relationele verbondenheid, deskundigheid en verantwoordelijkheid nodigen meer uit tot overleg, en roepen ook meer emoties op. Ethische problemen die zijn verbonden met het regelethische uitgangspunt van autonomie (als recht op zelfbeschikking), nodigen minder uit tot reflectie. Principes die vast verankerd liggen lijken weinig vragen en verwondering meer op te roepen.

Bij het bespreken van het dilemma in de zorg voor mevrouw Appelman hanteert de arts het principe van 'weldoen' en maakt hij de afweging tussen de mate van weldoen en die van te voorziene schadelijke bijwerkingen. Een vorm van redeneren die thuishoort in de regelethische traditie. Verpleegkundigen laten de stem van de patiënt horen en belichten vanuit het zorgethisch perspectief de relationele aspecten en claimen verantwoordelijkheid voor de zorgbehoefte van mevrouw in relatie tot de kwaliteit van leven. De patiënte zelf is niet aan het woord. Verbale communicatie in een gelijkwaardige dialoog is, door haar fysieke en psychische situatie niet goed mogelijk. Verpleegkundigen nemen die taak over. Door de dagelijkse zorg en de langdurige (zorg)relatie met haar, zijn zij in staat de signalen die zij van haar opvangen, te vertalen door in de discussie te wijzen op de effecten van de behandeling. Dit leidt tot het gezamenlijk inzicht (horizonversmelting), dat het beter is de behandeling te staken. Datzelfde gebeurt bij mevrouw IJzendoorn.

In de situaties van de heer Van Ommeren en ook bij de heer Zomers lijkt het de arts vooral te gaan om het principe van respect voor de autonomie van de patiënt. In het geval van de heer Van Ommeren is het de tweede arts die de relationele betrokkenheid laat gelden en aandacht vraagt voor de stem van de patiënt. Dit leidt tot nader onderzoek, door aandacht en gesprek, naar wat nu precies de behoefte, de zorgvraag is van deze patiënt. Zij brengt nuancering aan in de opvattingen over de angst van de heer van Ommeren. De verpleegkundige doet hetzelfde, zij verwijst terug naar de patiënt en het belang van zijn inbreng bij het omgaan met nieuwe situaties.

Ook het gesprek over de situatie van mevrouw Bellenbos kan gezien worden als deel van een hermeneutisch proces. Het gesprek leidt tot een beleidsbeslissing, niet tot een oplossing waar iedere betrokkene helemaal achter kan staan. Verwacht mag worden dat dit gesprek, met het oog op toekomstige patiënten, een vervolg zal hebben. De vragen zullen opnieuw 'opborrelen' als zich nieuwe soortgelijke situaties voordoen. Een werking die te vergelijken is met Giddens' 
(2000) life-political proces. De vervreemdende effecten van expertsystemen op de levens van individuen brengt een tegenbeweging op gang waardoor weggedrukte morele en existentiële vragen weer opborrelen, om aandacht en om oplossingen vragen. Mevrouw Bellenbos wordt geconfronteerd met een ongewenste en niet verwachte verandering in haar situatie. Het hospice zou haar 'laatste woning' zijn. Nu blijkt dat zij nog een keer moet verhuizen. Met dat toekomstbeeld had zij geen rekening gehouden. Ook vanuit de opvattingen die haar vanuit haar achtergrond en traditie vertrouwd zijn, is zij verwonderd en boos over de ontwikkelingen die boven haar hoofd hangen. Ze stelt kritische vragen 'afspraak is afspraak' en: 'iets wat mij zo direct raakt, moet eerst met mij besproken worden.' Zij weet zich kwetsbaar, niet alleen omdat ze zo ziek is, ook omdat ze de keus niet meer heeft eventueel naar haar eigen huis terug te keren. De behoeften en opvattingen van mevrouw die strijden met de opvattingen van professionals en de grenzen van de organisatie, zijn aanleiding tot het gesprek tussen zorgverleners onderling en tussen zorgverleners en patiënte. Zorgverleners worden geconfronteerd met hun eigen kwetsbaarheid, de goede zorg waartoe zij in staat zijn wordt beperkt door de tijd en ruimte waarover de organisatie beschikt. Het compromis dat men bereikt, houdt in dat mevrouw Bellenbos in ieder geval achteraf uitleg krijgt over de noodzaak van de overplaatsing en dat voor toekomstige patiënten het beleid moet worden aangescherpt zodat vooraf wordt aangeven wat mogelijk is en wat niet. Beleid dat niet zal voorkomen dat opnieuw mensen moeten 'doorschuiven' en plaatsmaken. Regels kunnen vastliggen en duidelijk zijn, dat zal niet voorkomen dat mensen het er moeilijk mee hebben als het hen betreft.

\subsection{De rol van de onderzoeker in het overleg}

Naast het registreren van ethische probleemsituaties en de omgang daarmee, had het bijwonen van het wekelijks overleg tot doel het in kaart brengen van besluitvorming op het gebied van ethiek. Vragen die het management daarbij had waren: 'Hebben wij wel voldoende oog voor de ethische kant?' en 'Zijn we niet te veel gericht op de lichamelijke aspecten?' In het licht van Giddens' life-politics, hebben deze vragen te maken met het onderkennen van de spanning tussen systeem en leefwereld in de dagelijkse zorgpraktijk. Vragen, die verbonden zijn met de behoefte trouw te blijven aan de oorspronkelijke en kenmerkende opvattingen van palliatieve zorg, die de behoefte van de patiënt en zijn naasten centraal wil stellen in een zorgverlening die niet alleen is gericht op fysieke noden, maar die alle aspecten van met menszijn in de zorg wil betrekken. In die zorg staat het relationele aspect voorop, zijn kwetsbaarheid en autonomie 
met elkaar verbonden en wordt gestreefd naar een klimaat van open communicatieve verhoudingen.

Om uiting te geven aan de waardering voor de gastvrijheid van het hospice voor het veldwerk van het onderzoek leek het me goed te voldoen aan het verzoek van het management over het bijwonen van de IZO-bijeenkomsten. Ook Hammersley en Atkinson (1995) wijzen in hun boek over etnografisch onderzoek op de ethische aspecten ervan. Zij vinden het belangrijk dat de onderzoeker er alert op is dat hij niet alleen zijn eigen belangen nastreeft, maar ook open staat voor de belangen van de onderzochte praktijk The argument about the exploitative potential of ethnographic research leads to a variety of recommenda. tions: that researchers should give something back...' p.274). Bovendien passen dergelijke vragen in responsive onderzoek. Responsive betekent dat het onderzoek in samenspraak en met respect voor anderen tot stand komt (Abma, 1996; Guba \& Lincoln, 1989). Belanghebbenden hebben een actieve rol als partners in het onderzoek met verantwoordelijkheid voor het bepalen van de inhoud ervan. Met belanghebbenden wordt verwezen naar diegenen die betrokken zijn bij de praktijk van het te onderzoeken werkveld.

Het bijwonen van het IZO bleek voor het onderzoek van groot belang. Naast de aanwezigheid in de praktijk, de interviews en andere gesprekken waarin aan de orde komt wat men belangrijk vindt, was het bijwonen van het IZO een mogelijkheid om te horen wat men doet in moeilijke situaties en welke argumenten tot besluitvorming leiden. Van elk overleg werd een verslag gemaakt en overlegd ter verificatie van mijn observaties en van de afspraken die werden gemaakt. Eind november 1999, drie maanden na het begin van het veldwerk en het bijwonen van het wekelijkse IZO, werd een tussenevaluatie gemaakt van observaties en interpretaties en aan het management toegestuurd voor overleg. Aan het eind van de periode van het veldwerk, in september 2000 vond opnieuw evaluatie plaats in een gesprek met het hoofd van de zorgverlening en de algemeen directeur, c.q. de pastoraal werkster. De matrix bleek een handig instrument om vast te leggen wat er gebeurde in het overleg. De verslagen hielpen bij het terugkoppelen in volgende bijeenkomsten op de afspraken die men maakte. Duidelijk was dat het in het overleg vooral ging om fysieke aspecten van de zorg en om het inspelen op acute situaties. Ethiek was wel aandachtspunt, maar niet opvallend. Mijn rol als onderzoeker was die van iemand die toehoort en aantekeningen maakt, zo was dat vantevoren afgesproken. Doordat ik wekelijks aanwezig was, werd ik een vertrouwd gezicht. Werd ik van relatieve buitenstaander meer een (onafhankelijk) 'insider' en werd in het overleg regelmatig mijn mening gevraagd. Ook zelf kon ik regelmatig de neiging niet onderdrukken te wijzen op inconsistenties of op eerdere discussies over eenzelfde onderwerp. Deze acties deden mijns inziens geen afbreuk aan mijn 
rol als onderzoeker maar voegden toe aan het onderdeel zijn van een praktijk die ik van binnenuit wilde leren kennen.

\subsection{Evaluatie IZO}

Niet alleen bij het management, ook in het wekelijks overleg klonk regelmatig de vraag hebben we wel voldoende oog voor... en dat niet alleen op gebied van ethiek, maar ook ten aanzien van begeleiding op sociaal en spiritueel terrein. Een vraag die alsmaar draaide om het eigene van de palliatieve zorg: 'doen we wel wat we zeggen te willen doen.' Een vraag die regelmatig opklonk, maar niet als vraag centraal werd gesteld. Steeds gerelateerd aan individuele situaties waarin problemen werden gesignaleerd, die om een oplossing vroegen. Wat opviel in die eerste periode, van september tot eind november, was dat het team van verschillende disciplines regelmatig niet voltallig aanwezig was, waardoor het multidisciplinaire aspect beperkt was. In de tweede periode van maart tot september 2000 was het team meestal wel volledig aanwezig. Bij afwezigheid van verschillende leden van het team gaat het overleg sneller, er kan minder ervaring worden gedeeld. Doelstelling van het IZO is om met behulp van de deskundigheden uit de verschillende bij de zorg betrokken disciplines situaties te belichten, de kwaliteit van de zorg voor patiënten te bewaken en zo mogelijk te verbeteren. Alle voorhanden zijnde deskundigheid, inzicht en ervaring kan op die manier worden ingezet ten behoeve van individuele zorgsituaties van dat moment. Het voltallig aanwezig zijn van de verschillende bij de zorg betrokken disciplines lijkt een belangrijke voorwaarde voor een goed functioneren van het IZO (McClelland, Sands I993). In het signaleren en inbrengen van ethische probleemsituaties en de besluitvorming daaromtrent, zijn het echter vaak dezelfde disciplines (artsen en verpleegkundigen) die hierin een rol spelen. De terugkerende ethische vragen in het hospice betreffen conflictsituaties, waarvan een beroep uitgaat op de verantwoordelijkheid van zorgverleners:

- Het overplaatsen van patiënten naar een verpleeghuis of elders tegen de wens of de verwachting van de patiënt. Een probleem dat zowel zorgethisch als regelethisch begrepen kan worden. Zowel het principe van weldoen als dat van de autonomie van de patiënt is in het geding. In de regelethische afweging wordt ingebracht dat overplaatsing op de lange termijn beter is voor de patiënt. 'De verpleeghuisomgeving is beter voor patiënte, men biedt er meer activiteiten, meer afleiding'. Het argument van weldoen weegt dan zwaarder dan dat van autonomie. Zorgethisch wordt autonomie verbonden met de kwetsbaarheid van de patiënt en het uitgangspunt van wederkerig. 
heid. Zorgverleners springen voor haar in de bres en voeren aan dat de inbreng van mevrouw een rol moet spelen in de besluitvorming. Het afstemmen van zorgvraag en zorgverlening begint en eindigt bij de patiënt. De discussie mondt uit in een regelethisch oplossing, het beleid, de regels aan te passen en voortaan bij opname aan patiënten duidelijk te maken, dat wanneer de situatie van de patiënt aanzienlijk verbetert zich stabiliseert, overplaatsing een van de mogelijkheden is.

- Beleid dat tijdens het overleg wordt afgesproken, wordt niet altijd door het gehele team gedragen én opgevolgd. In de terugkoppeling naar de verpleegkundige achterban over afspraken die in het IZO zijn gemaakt ontstaan soms andere inzichten, waardoor beleid wordt bijgesteld of niet wordt opgevolgd. Dit komt dan in het volgende overleg weer aan de orde. Een situatie die te maken heeft met de spanning tussen systeem en leefwereld. Beleidsafspraken zijn gerelateerd aan regels en mogelijkheden van de organisatie (zoals beschikbaarheid van mensen en middelen en het opname- en verblijfbeleid waardoor soms situaties ontstaan zoals het verkeerde bed') en niet a-priori aan de wensen en behoeften van patiënten en hun naasten. Dit leidt terugkerend tot emoties en existentiële vragen door zorgverleners over zin en betekenis van dat beleid in het licht van de zorg voor de patiënt om wie het gaat. Een steeds weer opborrelde bron, soms ook van ergernis.

- Het 'palliatieve' van sommige behandelingen komt ter sprake. Het zijn vaak de verpleegkundigen in het overleg die emoties tonen, vragen stellen over voor de patiënt belastende behandelingen. Soms komt dezelfde zorgsituatie met dezelfde vragen een aantal keren opnieuw op de agenda in het overleg.

Vaak bleken individuele moeilijke zorgsituaties in een week zodanig te veranderen, dat vragen die eerder (op)speelden, naar de achtergrond schoven om plaats te maken voor nieuwe.

- Duidelijke communicatie ten aanzien van beleid en afspraken naar patiënt en familie. Een goed begrip van de situatie bij patiënt en familie is van belang om zorgvraag en beleid te kunnen afstemmen. Dit vereist van artsen en verpleegkundigen een tijdig en voldoende informeren van patiënt en familie over achtergronden van (behandel)mogelijkheden, over afspraken en beleid. Soms werden hierin hiaten geconstateerd. De oorzaken waren divers, hadden er soms mee te maken dat wel met familie maar niet met patiënt was gesproken, men er door drukte nog niet aan toe was gekomen, of dat de informatie niet goed was gehoord of overgekomen.

De beleving van de patiënt en zijn naasten, de manier waarop zij omgaan met de ziekte en het naderend levenseinde, is een belangrijk aandachts- 
punt van zorgverleners in het hospice. Een terrein waar de spanning tussen systeem- en leefwereld een rol speelt in de verwachtingen en ervaringen van mensen. Vaak heeft men al een heel traject afgelegd van behandelingen en ziekenhuizen in de hoop op genezing. Om voldoende aandacht te hebben voor de psychosociale begeleiding is een 'begeleider naasten' aangesteld. Deze speelt samen met de pastor en het zorgverlenend team een belangrijke rol in afstemmen en uitleggen van beleid en zorgvragen. Omdat de begeleider naasten, door de part-time functie, niet aanwezig is in het IZO, vindt rapportage schriftelijk plaats, mondeling toegelicht op dagen dat zij aanwezig is. In sommige gevallen werd dit als een knelpunt ervaren.

- Verschil van inzicht tussen zorgverleners en familie over de kwaliteit van de zorg.

Zoals in de situatie van de heer Van Vliet die eerder met zijn vrouw afspraken maakte over hoe om te gaan met toenemende lichamelijke klachten toen duidelijk werd dat hij binnen afzienbare tijd zelf niet meer zou kunnen praten (hoofdstuk 3). Een situatie die veel spanning en emoties en omroept bij zorgverleners en hen confronteert met existentiële vragen en communicatieve onmacht. Een situatie die door sommigen als hopeloos werd ervaren maar desondanks bleef vragen om inlevingsvermogen en overleg.

In het bespreken van de evaluaties van de stand van zaken zoals deze door mij werd geinterpreteerd en waargenomen, werd met name stilgestaan bij het probleem van 'het verkeerde bed'. Een bed in het hospice is bedoeld voor patiënten in de laatste fase van hun leven, gedacht wordt daarbij aan enkele dagen tot weken, met een maximum van drie maanden. In de praktijk gebeurt het regelmatig dat eenmaal opgenomen in het hospice, de situatie van de patiënt zich zodanig verbetert, dat men zich afvraagt of het niet beter is de patiënt over te plaatsen. Voorstellen in die richting hebben in het verleden tot problemen geleid zowel voor de patiënt als voor de zorgverleners. Tegenwoordig probeert men zo vroeg mogelijk te signaleren en actie te ondernemen wanneer men het idee krijgt dat 'iemand niet op zijn plaats is' in het hospice. De indicatiecommissie wordt ingeschakeld en de procedure van overplaatsing wordt, na overleg met patiënt en/of familie, in werking gezet. Vaak ziet men dan het volgende gebeuren: de patiënt wil niet opnieuw verhuizen of ziet erg op tegen opname in een verpleeghuis, als reactie verslechtert opnieuw de lichamelijke situatie en wordt het proces van overplaatsen opgeschort. Na stabilisatie van dit proces wordt opnieuw een poging ondernomen, soms met hetzelfde effect. Wat lijkt te stagneren is een bevredigend antwoord op de behoefte van de 
patiënt om te mogen blijven waar hij of zij nu naar tevredenheid verblijft. Om dit te verduidelijken nog eens kort de achtereenvolgende stappen in het proces:

- Het herkennen van de zorgvraag vond plaats in de thuissituatie of in het ziekenhuis: het kon niet langer zo, patiënt en/of familie hebben behoefte aan meer veiligheid en rust, hulp bij het omgaan met pijn en andere symptomen. Het levenseinde lijkt dichtbij.

- Met instemming van alle partijen vindt opname in het hospice plaats.

- Pijn wordt deskundig bestreden, verzorging en aandacht dragen bij aan het welbevinden van de patiënt. De familie wordt opgevangen.

- De situatie stabiliseert zich, de verzorging vraagt zich af: is deze patiënt hier wel op zijn/haar plaats?

Als men deze vraag aan de patiënt zelf stelt is het antwoord in de meeste gevallen, ja. Maar het gaat hier om een vraag die oprijst uit de organisatie. Niet de behoefte van de patiënt maar de 'realiteit' van de organisatie staat op het spel. Dit moet worden terugvertaald naar de patiënt in de hoop dat hij/zij begrip heeft voor deze grenzen.

De analyse van de verkeerde bed - problematiek leverde geen oplossing op. Geen nieuwe kennis of verklaringen, maar inzicht in details en opeenvolgende patronen van gebeurtenissen in deze steeds unieke situaties (Abma, 1996, p.89). Net als voor de betreffende patiënten kan het voor zorgverleners moeilijk zijn tegen de wil of het verlangen van de patiënt mee te werken aan overplaatsing. De uitdrukking ' $l k$ vraag me af of deze patiënt hier wel thuis hoort' wordt gesteld vanuit de doelstelling en mogelijkheden van de organisatie. Ook de argumentatie ' $I k$ heb het idee dat hij/zij meer afleiding, meer activiteiten nodig heeft' wordt daardoor gevoed. Hoewel het argument is verbonden met behoeften die men waarneemt, is de richting van de oplossing niet die waar de patiënt zin in heeft. Deze is veelal naar het hospice gebracht met het idee van een 'laatste (veilige) plek' en de verwachting daar te zullen overlijden. Duidelijker afspraken bij opname van nieuwe patiënten kunnen misschien een deel van dit soort moeilijke situaties voorkomen. Regels en aangescherpt beleid als oplossing voor een probleem dat met name zorgethische vragen oproept maakt de situatie die aan de orde is voor zorgverleners misschien draaglijk, er wordt immers iets aan gedaan en regels geven houvast en helderheid. Ze legitimeren het handelen. Tegelijk zal men zich realiseren dat de mensen om wie het gaat bij opname kwetsbaar zijn en in een crisissituaties verkeren. Het hospice is voor hen een plek om het laatste stukje van hun leven in veilige handen te zijn. Regels over duur van verblijf zijn waarschijnlijk noodzakelijk, maar zij zullen problemen die zich voor patiënt en zorgverleners bij overplaatsing naar een verpleeghuis kunnen voordoen, in de toekomst niet voorkomen. Die spanning 
blijft bestaan en is verbonden met het tragisch karakter van het bestaan dat mensen confronteert met tegenstrijdige eisen en verplichtingen. Waar regels een oplossing bieden, moet men vanuit het belevingsperspectief (leefwereld/ levensverhaal) vaak erkennen dat die oplossing ook een zekere mate van onrecht impliceert (Widdershoven, 2000; Nussbaum, 1989).

Ook werd stilgestaan bij het probleem ten aanzien van vastgesteld beleid dat niet wordt uitgevoerd, of onvoldoende wordt opgevolgd (één lijn trekken). Waar belangen van patiënten en de regels en/of mogelijkheden van de organisatie elkaar kruisen kunnen verschillende blikvelden tegenover elkaar komen staan: de een vertegenwoordigt het belang, het bestaan en de continuïteit van het bedrijf, de ander dat van de individuele patiënt. Een situatie die frustratie en emoties oproept bij zowel de patiënt als de zorgverleners. Situaties waarnaar door The (1997b), Kunneman (1998) en Verkerk (2000) wordt verwezen (zie ook Hoofdstuk 3). The noemt een van de waarschijnlijk zwaarste aspecten van verpleging de directe confrontatie met menselijk lijden. Verpleegkundigen worden door de dagelijkse directe zorg geconfronteerd met angst en verdriet, verbonden met het afscheid nemen van het leven. Eigen emoties bij het verplegen spelen een rol en zijn lang niet altijd te onderdrukken. Tegelijk maken verpleegkundigen deel uit van de organisatie waarin zij zorgverlenen. Zij staan dichter dan de patiënt en zijn of haar familie bij de arts, zijn vertrouwd met het medisch taalgebruik en kennen de grenzen en mogelijkheden van de organisatie. Dit brengt verpleegkundigen in bepaalde situaties, zoals het verkeerde bed, in een positie die frustrerend is en spanning oplevert. Verkerk (2000) pleit voor een regelmatig terugkerend moreel beraad, waarin betrokkenen hun zienswijze op goede zorg inbrengen en met elkaar beraadslagen over moeilijke situaties. Het instellen van een moreel beraad is echter niet voldoende. In de sociale context van de zorgorganisatie werken professionals samen, maar speelt ook hiërarchie een rol en nemen actoren onderscheiden machtsposities in. Het management van zorgorganisaties heeft de verantwoordelijkheid ruimte te geven en voorwaarden te creëren om hulpverleners in staat te stellen zich bewust te zijn van de ethische dimensie van het werk en ermee om te gaan in de dagelijkse zorgverlening. Ook Kunneman (1998) verwijst naar mogelijkheidsvoorwaarden om zo'n beraad te kunnen houden. Zorgverleners moeten in staat worden gesteld de professionele en technische competenties te integreren in normatieve betrokkenheid. Van de organisatie wordt gevraagd een klimaat te scheppen waarin open en gelijkwaardige communicatie mogelijk is en wordt gewaardeerd, waar vragen, ook trage vragen, gehoord mogen worden en schijnconsensus wordt ontmaskerd.

In het wekelijks IZO komen ethische aspecten aan de orde, een veel groter deel van het overleg wordt besteed aan lichamelijke- en ook aan sociale- en psychi- 
sche en levensbeschouwelijke aspecten van de zorg aan patiënten en hun naasten. De tijd is beperkt, in een krappe 90 minuten wordt de agenda gevolgd en wordt stilgestaan bij wie is overleden en hoe dat is verlopen, bij nieuwe opnamen en wat de problemen en verwachtingen zijn, de zorg voor de reeds opgenomen patiënten passeert de revue en er wordt vooruitgekeken naar planning van nieuwe opnamen. Dit vraagt van de aanwezigen de discipline om bij de les te blijven, niet onnodig uit te weiden en toch de relevante ideeën, ervaringen, gevoelens en observaties in te brengen en daarover op open en gelijkwaardige manier met elkaar van gedachten te wisselen met het oog op kwaliteit van zorg. Een wekelijks IZO waarin zoveel voor het voetlicht komt lijkt onvoldoende gelegenheid om ethiek een volwaardige plaats te geven in het kwaliteitsbeleid en dagelijkse praktijk. Toch is het IZO tegelijk een uitgelezen mogelijkheid voor regelmatig en geïntegreerd moreel overleg. Het biedt zorgverleners de gelegenheid spontaan te reflecteren op concrete ervaringen, emoties en ethische gezichtspunten naar voren te brengen. Een plek waar Giddens' life-politics kansen krijgt. De multidisciplinaire benadering van concrete casuisstiek geeft ruimte voor het vanuit verschillende invalshoeken belichten en interpreteren van verhalen die zijn verbonden met de zorg voor individuele patiënten, en voor de emoties en ethische vragen die daarbij een rol spelen. Een praktisch voorbeeld van Nussbaums (1998) narratieve benadering van de ethiek. Een benadering die ethisch redeneren verbindt met concrete situaties en de rol van emoties in de ethiek benadrukt. Dat betekent dat naast dominante opvattingen en regels aandacht geschonken moet worden aan de concrete (levens)ervaringen, aan verhalen die men elkaar vertelt en die men in het werk tegenkomt. 'Alleen zo kunnen we algemeen beleid een menselijk gezicht geven' (Nussbaum, 1998, p.20).

De rol die de onderzoeker zelf speelde door haar aanwezigheid in de praktijk werd in de bespreking in december 1999 en tijdens het afsluitend overleg in september 2000 met het management van het hospice besproken. Aangegeven werd dat, alleen al door haar aanwezigheid, het onderwerp ethiek meer in beeld kwam bij zorgverleners en management en men meer mogelijkheden zag en aangreep ethiek op de agenda te plaatsen. Waarbij de vraag rijst hoe de afwezigheid van zo iemand werkt. Maakt het werkelijk verschil en vindt men het belangrijk? Hoe wordt aan continuīteit gewerkt? Datzelfde geldt voor de suggesties uit de evaluaties: hebben zij het overleg veranderd? Het zijn vragen die ik me achter mijn bureau stel nu het onderzoek al enige tijd achter me ligt, een vraag die opnieuw aan de praktijk gesteld zou moeten worden.

De verslagen van het IZO, die wekelijks werden toegestuurd, bleken bij te dragen aan een beter overzicht van wat besproken was en welke afspraken werden 
gemaakt. Eerder werden alle afspraken en wijzigingen in beleid in de individuele zorgdossiers genoteerd. Een totaaloverzicht ontbrak. De suggestie een verslag te maken van elk overleg, werd na afloop van het onderzoek overgenomen. Een andere suggestie aan het management was om in het bespreken van ethische problemen meer systematisch vragen te stellen.

De volgende condities geven een door Verkerk (2000) bepleit moreel beraad (hier geïntegreerd in het IZO), meer kans:

- Om de verschillende perspectieven en deskundigheden een stem te kunnen geven dient te worden gestreefd naar voltallige aanwezigheid van het team;

- Niet de regels, maar de concrete casuistiek is uitgangspunt;

- Aanwezigheid van een deskundige (van buiten het team) op gebied van ethiek kan behulpzaam zijn;

- Kwaliteit van communicatie die ruimte biedt voor dialoog en reflectie; aandacht voor remmende factoren zoals de nadruk op regels of op principes zoals autonomie als negatieve vrijheid;

- In het bespreken van ethische problemen systematischer vragen stellen. Ethisch theoretische uitgangspunten zoals in eerdere hoofdstukken beschreven, zijn hiervoor inspiratiebron:

- Zorgethisch:

- Hoe wordt de zorgvraag door betrokken zorgverleners geïnterpreteerd?

- Welke verantwoordelijkheden roept dat op, welke zorg moet worden georganiseerd?

- Welke deskundigheden zijn hiervoor nodig, zijn deze beschikbaar: intern of extern?

- Wordt in het zorgproces, het plannen en organiseren van zorg steeds afgestemd op de (mogelijk veranderende) behoeften van patiënt cq. naasten?

- Regelethisch:

- Ga na welk ethisch principe (of principes) in het geding zijn?

- Welk principe weegt het zwaarst? Voor patiënt/naasten/zorgverleners.

- Waarom is dat zo: specificeer het belang van de principes/het principe dat de meeste aandacht vraagt en kom tot afweging van strategieën om verder te gaan 


\subsection{Samenvatting}

In dit hoofdstuk werd het IZO beschouwd als vorm van moreel beraad. Stilgestaan werd bij de inhoud en doelstellingen van dit wekelijks overleg en het bijwonen ervan. Ethische problemen die in het overleg werden besproken, handelden rond de thema's: verantwoordelijkeid voor kwaliteit van leven; autonomie van de patiënt en aandacht voor de zorgbehoefte. Bij de beschrijving van de voorbeelden is ingegaan op de manier waarop men spreekt over die problemen en hoe besluitvorming tot stand komt. De benadering van ethische problemen in het overleg is vaak weinig systematisch en afhankelijk van de personen die op dat moment in het overleg aanwezig zijn. Het valt op dat het vaak de arts en de verpleegkundigen zijn in het multidisciplinair overleg, die ethische onderwerpen naar voren brengen en de besluitvorming richting geven. Een verklaring hiervoor ligt wellicht in de verantwoordelijkheid van hun discipline en de betrokkenheid die hun werk in de praktijk met zich meebrengt. In de dagelijkse zorgverlening hebben verpleegkundigen nauw contact met patiënten en ook vaak met de familie, hun relationele betrokkenheid is groot. Ook artsen in hun begeleiding van de zieke tot aan het overlijden, staan dicht bij de patiënt en zijn of haar familie (The, 1997a). In discussies worden regelethische en zorgethisch argumenten naar voren gebracht. Daarbij valt op dat het vooral verpleegkundigen zijn die de stem van de patiënt vertolken (die dat zelf vaak niet meer kan), relationele betrokkenheid tonen en opkomen voor kwaliteit van leven. In het omgaan met ethische problemen speelt de spanning tussen systeemeisen en leefwerelddimensies steeds weer een rol. Regelethiek, het afwegen van waarden, is veelal leidinggevend in het bepalen van beleid.

Hoewel reflectie en besluitvorming soms eenzijdig tot stand komen, wordt aan de hand van verschillende voorbeelden beschreven hoe de hermeneutiek werkzaam kan zijn in dat proces. Ook in de regelethiek is communicatie belangrijk. Toch vindt juist in situaties waarin het gaat om het recht op zelfbeschikking (na informed consent) weinig reflectie plaats. Een onderwerp dat in het volgend hoofdstuk opnieuw aandacht zal krijgen in de beschrijving van het proces van beleidsontwikkeling ten aanzien van sedatie.

Ook aan het effect van de aanwezigheid van de onderzoeker in de praktijk wordt aandacht gegeven. Management en individuele zorgverleners maakten duidelijk dat alleen al de aanwezigheid van iemand van buiten het team, met speciale belangstelling voor de ethische dimensie van het werk, hielp om daarvoor meer aandacht te hebben. Hoe dit na haar vertrek aandacht blijft krijgen is daarmee niet gezegd. De evaluatie van het IZO mondt uit in een aantal condities voor moreel beraad. 



\section{Wat bindt raakt}

in de tijd

geschonden,

niets gespaard;

wat blijft is

vastgeschroefd,

verlangend

naar

verbondenheid. 



\section{Ethisch kwaliteitsbeleid}

\subsection{Inleiding}

Begrippen als 'goede zorg' en 'kwaliteit van leven' zullen in beleid en doelstellingen van zorgorganisaties niet ontbreken. Wat die begrippen precies betekenen moet echter steeds opnieuw door betrokkenen worden vastgesteld, in een gezamenlijk proces van afwegen en bespreken. Zorgorganisaties zijn verantwoordelijkheidspraktijken; de betrokkenen dragen verantwoordelijkheid voor elkaar en voor zichzelf. Hoe zorgorganisaties daarover denken, komt bijvoorbeeld tot uitdrukking in de manier waarop zij zich in hun naamgeving presenteren aan de samenleving: hospice, gasthuis, een plaats van ontmoeting, een bijna-thuis-huis. Termen die verbonden zijn met veiligheid, respect, een plaats waar je net als thuis, jezelf kunt zijn.

Een ethiek van zorg en verantwoordelijkheid is niet iets waarvoor alleen de zorgverleners verantwoordelijkheid dragen. De organisatie, het management heeft de taak de voorwaarden te scheppen om de morele dimensies van het werk zichtbaar te maken en te houden. Dit door ruimte te creëren om situaties ter sprake te kunnen brengen waarin zorgverleners, patiënten, familie of andere betrokkenen zich geconfronteerd zien met morele problemen.

Kunneman introduceert de term horizontaal kwaliteitsbeleid. Een benadering die is gebaseerd op gelijkwaardige communicatieve verhoudingen binnen de organisatie. Niet alleen patiënten, ook zorgverleners weten zich gezien en serieus genomen. $\mathrm{Zij}$ worden gestimuleerd om in de omgang met morele vragen die het werk in de palliatieve zorgverlening met zich meebrengt, niet alleen hun deskundigheid vanuit technisch-professiononeel kader in te brengen, maar daarbij ook de eigen existentiële hulpbronnen in te schakelen. Dit om in staat te zijn contact te leggen met de bestaansknopen van patiënten en met de eventuele verworteling daarvan in de maatschappelijke context (Kunneman, 1998 p.125). De randvoorwaarden waar het hier omgaat, zijn volgens Kunneman van een moreel karakter: het gaat om de communicatieve kwaliteit van de onderlinge omgang, om de mate waarin emoties worden genegeerd of 
een stem hebben. Horizontaal kwaliteitsbeleid wordt niet alleen gekenmerkt door de communicatieve kwaliteit van relaties, ook de zorg wordt als communicatief proces vormgegeven.

Gaat het hier om een theoretisch ideaal, of kan de praktijk er werkelijk zo uitzien, dat ethiek is geïntegreerd in de dagelijkse praktijk en het beleid van zorgorganisaties?

Een probleem dat tijdens het veldonderzoek in een ethisch beraad aan de orde werd gesteld, betrof sedatie in de laatste levensfase. Een situatie die ter sprake kan komen wanneer symptoombestrijding onvoldoende succes heeft en de patiënt ernstig lijdt. In dit hoofdstuk wordt het proces beschreven waarin, aan de hand van een door zorgverleners als zeer problematisch ervaren praktijksituatie, beleid is ontwikkeld. Een communicatief proces, waaraan zorgverleners vanuit verschillend perspectief, vanuit eigen achtergrond en betrokkenheid én vanuit hun kennis en ervaring hebben bijgedragen. In dit hoofdstuk wordt ingegaan op de start, de verschillende fasen in het proces, wie erbij waren betrokken en hoe ik de bijeenkomsten voorbereidde en hoe ze verliepen. Ook wordt ingegaan op wat het soms moeilijk maakte het proces gaande te houden en hoe het met het beleid verder ging na afloop van het onderzoek.

\subsection{De dynamiek van 'trage vragen' rond sedatie}

De spanningsverhoudingen die de moderne tijd kenmerken zijn voelbaar en merkbaar in de afstand tussen systeemeisen en leefwereldbehoeften en ervaringen, tussen werk en privé-leven. De daaraan ten grondslag liggende rationaliserings- en individualiseringstendensen hebben bijgedragen aan de ontwikkeling van expertsystemen, waarbinnen cognitieve leerprocessen domineren. Tegelijk droeg de onderdrukkende werking ervan binnen de gezondheidszorg bij tot het stellen van zingevingsvragen, en vragen als 'Wat is goede zorg voor mensen bij het naderend levenseinde?' en 'Hoe daar ruimte voor te maken?' Vragen die ten grondslag hebben gelegen aan de start en de ontwikkeling van palliatieve zorg in Nederland. Een voorbeeld van Giddens' life-politics (hoofdstuk I). Dit betekent niet dat de palliatieve zorg gevrijwaard is van deze spanningsverhoudingen. Ook daar heeft men te maken met systeem- en leefwereldspanningen. De interviews en de ervaringen in het IZO laten voorbeelden ervan zien. Ook binnen het palliatieve vakgebied is sprake van nieuwe ontwikkelingen en technische vooruitgang. Op het gebied van pijn- en symptoombestrijding is sinds de beginperiode grote vooruitgang geboekt. Waren in de beginperiode verpleeg- en medisch-technische hulpmiddelen (zoals morfine- 
pompjes, het gebruik van infusen en spinaalkatheters) binnen de hospicezorg zeer beperkt, in de huidige 'high care' hospices zijn ze een normaal verschijnsel. Ontwikkelingen die veel goeds bijdragen, maar tegelijk gemakkelijk de indruk wekken dat problemen en vragen die zich in de praktijk voordoen, steeds met behulp van techniek en cognitieve leerprocessen zijn op te lossen en beheersbaar gemaakt kunnen worden. Zingevingsvragen, emoties en ethische problemen die de zorgverlening ook kenmerken, passen niet in dat kader. Het zijn vragen die soms lang blijven 'liggen', zij worden onder de druk van het werk en de dingen die moeten worden gedaan en om voorrang vragen, vaak weggestopt. Toch blijven ze hoorbaar in tal van opmerkingen en zuchten van zorgverleners: 'Dat de patiënt hier niet langer hoort, is iets waar mijn haren van overeind gaan staan'; 'Ik heb er geen antwoord op..'; 'Want wat is dat ontzettend moeilijk als je iemand zo ziet lijden en hij weigert pijnbestrijding'; 'Ik vind het wel eens moeilijk als mensen hun intiemste dingen aan mij vertellen, hun pijn, hun machteloosheid, hun schuldgevoel'

En ook in de geluiden vanuit het management: 'Hebben wij wel voldoende oog voor...' en: 'Zijn we niet te veel gericht op lichamelijke aspecten?'

Het zijn vragen die gesteld blijven worden ondanks de systeemdruk, die vertaald in regels en protocollen weinig ruimte biedt voor deze existentiële en morele vragen en emoties. Dimensies die belangrijk zijn voor de kwaliteit van de praktijk van zorg en verantwoordelijkheid.

Het steeds weer opborrelen van dit soort vragen, dat er ruimte is voor die vragen én dat er iets mee gebeurt, is wat Giddens (200I) verstaat als life-politics en wat Kunneman (1999) trage vragen noemt. Zij gaan over zin en betekenis, over moraliteit en identiteit, vragen die niet passen in de logica van beheersbaarheid, van economische motieven en van rationaliteit. Het zijn deze vragen die er voor zorgen dat de leefwereldervaringen, de verhalen van mensen ertoe blijven doen en houvast bieden in de gezamenlijke zoektocht naar (leefbare) antwoorden.

Vragen van deze orde waren het, waardoor mij de mogelijkheid geboden werd om de eerder geplande groepsbijeenkomsten alsnog te organiseren. Het ging om ervaringen van zorgverleners met een zorgsituatie die erg moeilijk was geweest voor de patiënt maar ook voor de mensen die bij de zorg waren betrokken. $\mathrm{Zij}$ waren gefrustreerd, hadden het gevoel dat zij te kort waren geschoten. Er was boosheid over procedures en communicatie die 'te traag' en niet adequaat waren verlopen en over het onvermogen om regels te interpreteren in het licht van de zorgvraag van de patiënt.

De term zorgverlener misleidt gemakkelijk, als zou het alleen gaan om zorg voor anderen, patiënten, naasten. Ook zorgverleners hebben behoefte aan zorg. Een van de manieren om op de kwetsbaarheid van zorgverleners te reage- 
ren is het regelmatig organiseren van een ethisch beraad, waarin moeilijke zorgsituaties kunnen worden besproken, ervaringen kunnen worden uitgewisseld en gezamenlijk kan worden nagedacht over het omgaan met de complexe zorgpraktijk en de vragen en problemen die die praktijk soms met zich meebrengt. De zorgsituatie die aanleiding was voor het ethisch beraad dat ik zou gaan begeleiden was de volgende:

Mijnheer Altena, geboren in 1919, leed aan een ontsteking van de galwegen. De aandoening is niet te opereren. Er is wel een buisje geplaatst om het vocht af te voeren. Mijnheer verbleef in het ziekenhuis, hij heeft veel last van diarree. Op de dag voor opname in het hospice is hij gevallen. Als gevolg daarvan heeft hij een groot hematoom op arm en rug. Deze bloeduitstorting verplaatst zich. In het ziekenhuis heeft mijnheer Altena een euthanasiewens geuit. Toen daaraan geen gehoor werd gegeven is hij boos geworden en wilde eigenlijk meteen naar huis. Hij stemt echter in met overplaatsing naar het hospice.

Bij intake door de hospice arts maakt hij een sombere indruk. Hij is gelaten en verdrietig. De hospice arts maakt duidelijk dat in het hospice geen euthanasie mogelijk is. In dat gesprek blijkt dat de euthanasiewens al eerder met de huisarts is besproken, maar ook door de huisarts werd afgewezen. Eigenlijk ziet hij opname in het hospice ook niet zo zitten, toch lijkt hij akkoord te gaan. Bij opname heeft mijnheer Altena nog steeds diarree. Hij heeft doorligwonden, het hematoom en een necrotische plek op de rug. Hij ontkent echter dat hij pijn heeft.

Vanaf de tweede dag wordt de fysiotherapeut ingeschakeld om mijnheer wat te mobiliseren. Mijnheer Altena heeft echter geen interesse. Hij lijkt op de dood te wachten. Hij uit zich daarover op dag vier: 'Het leven is hem niets meer waard.' Bij de verzorging merken verpleegkundigen dat aanraken pijnlijk is. Echter de pijn wordt ontkend. De heer Altena heeft maar een wens: sterven. De diarree is gestopt, zijn stuit is zwart, de wonden gaan stinken. Zorgverleners herkennen duidelijk de euthanasiewens van de patiënt. Zij hebben veel moeite met de situatie. Mijnheer Altena communiceert niet meer met hen. Hij draait hen letterlijk de rug toe en spreekt niet meer.

Er ontstaat een discussie tussen arts en verpleging. Door de verpleging wordt voorgesteld de patiēnt te sederen tot hij in slaap valt om niet meer wakker te worden. Het argument van de arts is echter: de patiënt heeft geen pijn, ik kan niet sederen. En hij vraagt: 'Wat is het verschil tussen de heer Altena op deze manier in slaap brengen en euthanasie?'

De heer Altena is de dag daarop overleden, zonder ingrijpen van de arts. Verpleging en ook de arts hebben problemen met de situatie.

Een van de verpleegkundigen vertelde dat zij de heer Altena wel had willen influisteren 'andere taal' te gebruiken voor zijn wens om te sterven. 'Zijn zie- 
lenpijn was vele malen groter dan zijn lichamelijke pijn. Als hij geveinsd had en gezegd had: pijn, dan was sederen geen probleem geweest.'

De term ethisch beraad misleidt gemakkelijk. In eerdere hoofdstukken (hoofdstuk 3 en 6) werd er al op gewezen dat binnen organisaties, ook die van de zorg, sprake is van verschillende machtsposities (Verkerk, 2000; Kunneman, 1998; 1999). Het is belangrijk hier oog voor te hebben en voorwaarden te scheppen die een vrij en gelijkwaardig overleg mogelijk maken en daar ook steeds attent op te blijven. Machtsverhoudingen kunnen de besluitvorming gemakkelijk beinvloeden. Dit komt de kwaliteit van het communicatief overleg niet ten goede. Hiërarchische verhoudingen kunnen belemmerend werken in overleg waarin het om kwetsbaarheid gaat, kwetsbaarheid van patiënten maar ook van zorgverleners. Het gevaar dat onder de vlag van ethisch beraad eenzijdige oplossingen tot stand komen, is altijd aanwezig wanneer er geen vrije communicatie mogelijk is. Op besluiten die onder dergelijke condities zijn genomen, wordt het ook lastig terug te komen: er was immers ethisch beraad. De eerste groepsbijeenkomst in oktober 1999 werd geheel in beslag genomen door het uiteenzetten van de geschiedenis van de heer Altena, die op alle zorg. verleners, ook die niet direct bij de zorg betrokken waren, diepe indruk had gemaakt. Het was een multidisciplinair overleg, waaraan verpleegkundigen, artsen, een fysiotherapeut, de pastoraal werker en het management deelnamen. De sfeer was open, hoewel er spanning voelbaar was vanuit (verpleeg. kundige)zorgverleners die hadden uitgezien naar het moment van dit overleg om uitvoerig te kunnen spreken over hun ervaringen. Begonnen werd met het uitwisselen daarvan, waarbij met name verpleegkundigen aan het woord waren. Dit mondde uit in een aantal concrete vragen: 'Hoe hadden we beter voor de heer Altena kunnen zorgen?'; 'Er was duidelijk sprake van ondraaglijk lijden, waarom konden we daar niets aan doen?'; 'Wat te doen, als de euthanasiewens blijft bestaan en de patiënt pijnbestrijding afwijst?'; 'Wat is het verschil tussen in slaap brengen en euthanasie?'

De vragen en de erkenning van de problemen en de pijn die dat ook voor zorg. verleners meebracht, zetten het verdere proces in gang. Een nieuwe bijeenkomst werd gepland voor december.

\section{3 Discussie over het begrip sedatie}

In de voorbereiding van de tweede bijeenkomst maakte ik sheets van de verschillende door Tronto (1993) beschreven fasen van het zorgproces. Nadenkend daarover zag ik parallellen en mogelijkheden om het proces van 
beleidsontwikkeling in multidisciplinaire groepsbijeenkomsten vanuit dat kader te begeleiden. Ik had daarbij niet de bedoeling het proces een bepaalde richting op te sturen. De bedoeling was zorgverleners een theoretisch raamwerk te bieden dat hun blik zou kunnen verruimen zowel met het oog op de zorgsituatie die aanleiding vormde voor het overleg, als ten aanzien van toekomstige situaties. Door mijn ervaringen met en belangstelling voor de palliatieve zorg, door het veldwerk in het hospice en de bekendheid met de meeste zorgverleners, was er een basis van vertrouwen gegroeid zowel bij het management als bij de zorgverleners. Bekendheid met de praktijk en vertrouwen, beide belangrijke criteria voor een klimaat van gelijkwaardigheid om te discussiëren over ervaringen en vragen die mensen diep raken (Abma, I996, p.I4I; Guba \& Lincoln, 1989 p. 132). Ethisch theoretische perspectieven droegen, samen met praktische kennis en ervaring als bagage, bij aan de rol van onderzoeker als instrument, als facilitator.

In de eerste bijeenkomst in oktober ging het vooral om herkennen van de zorgvraag. In de verhalen van zorgverleners werd op verschillende manieren de zorgvraag van de heer Altena verwoord. Voor de beleidsontwikkeling kwam daarbij de vraag van zorgverleners centraal te staan: 'Kunnen we met elkaar afspraken maken die houvast bieden voor soortgelijke situaties in de toekomst?' De erkenning van deze behoefte bracht het proces van gezamenlijke beleidsontwikkeling op gang. Ik zag het als een eerste fase van een zorgproces waarin het gaat om aandacht voor de zorgbehoeften. Goede zorg valt of staat met het vermogen en de bereidheid om zich te verplaatsen in de behoeften en perspectieven van anderen (Sevenhuijsen, 2000). Er kwam een proces op gang om gezamenlijk over die vraag na te denken en vanuit ieders competentie daaraan een bijdrage te leveren. De tweede bijeenkomst zou in het licht staan van verantwoordelijkheid. Een ethiek van zorg roept op tot verantwoordelijkheid. Echter de manier waarop deze verantwoordelijkheid wordt ingezet, kan heel verschillend zijn. Vanuit de regelethiek is de arts bijvoorbeeld verplicht patiënten zo goed mogelijk voor te lichten, verplichte verantwoordelijkheid dus. Zorgethiek houdt een ontvankelijkheid in voor de zorgvragen van anderen, niet omdat we dat aan hen verplicht zijn, maar omdat we daarmee onze zorg voor hen tot uitdrukking brengen. 'Een verantwoordelijke zorgverlener is iemand die niet zozeer de regels weet toe te passen, maar zich morele vaardigheden van ontvankelijkheid en aandachtigheid heeft eigen gemaakt, en op gepaste wijze op zorgvragen van patiënten weet te reageren (Verkerk, 2000, p.ri8). Tronto (1993, p. 131) hanteert de term 'a flexible notion of responsibility' om aan te geven dat het niet enkel gaat om het voldoen aan verplichtingen. Een organisatie als zorg-, en verantwoordelijkheidspraktijk heeft ook zorg en aandacht voor haar zorgverleners. De bijeenkomst in december is opnieuw een multidisciplinair verband. Voor 
een deel zijn het dezelfde mensen als in oktober, maar ook andere zorgverleners nemen deel evenals het management. De bijeenkomsten worden niet op de band opgenomen. Van elke bijeenkomst wordt een verslag gemaakt en aan betrokkenen toegestuurd. De bijeenkomst in december start met een terugblik op het vorig overleg en het verslag ervan. Dan volgt een korte introductie van regel- en zorgethiek. Met de vragen van zorgverleners uit het vorige overleg, in een iets andere vorm herschreven, begon de discussie en het overleg:

I Wat is het verschil als we iemand zodanig sederen tot hij of zij in slaap valt en uiteindelijk zonder wakker te worden overlijdt, en euthanasie?

2 Wanneer mag de arts dat middel inzetten (laten slapen): ter verlichting van de lichamelijke pijn die de patiënt aangeeft of mag het ook 'zielenpijn' zijn?

3 Is het 'laten slapen' een alternatief aanbod voor mensen die euthanasie vragen?

Er ontstond een levendige discussie, waaraan alle aanwezigen deelnamen. De eerste vraag riep bij zorgverleners associaties op van andere zorgsituaties. $\mathrm{Er}$ werden voorbeelden genoemd waarbij volgens sommige verpleegkundigen sederen en euthanasie zo dicht bij elkaar lagen, dat het moeilijk was het onderscheid goed te zien of om dat onderscheid uit te leggen. Wanneer spreken we van sedatie, wanneer van pijnbestrijding? Wat is het verschil met euthanasie? Veel middelen tot pijnbestrijding hebben een sederende werking. De vage grens tussen sederen en euthanasie werd door de artsen erkend. Ook bij nabestaanden blijkt er soms onduidelijkheid over te bestaan. Nuij en Hoogerwerf (2000, p.r23) spreken over een 'schemergebied' tussen pijnbestrijding en euthanasie: 'Door het leed te verzachten, draaglijk te maken opdat er ook ruimte ontstaat voor andere dimensies in het eindige bestaan van de patiënt - het wezenlijke van de palliatieve zorg - bespoedigt de arts soms het sterven van de patiënt. In dit schemergebied wordt sedert I99I de term terminale sedatie gebruikt.' Hoewel artsen in het overleg die dunne grens erkenden, is er volgens hen ook een duidelijk verschil tussen sedatie en euthanasie. Het verschil zit in de intentie. Sedatie kan worden ingezet als symptomen niet voldoende reageren op de behandeling en de patiënt ernstig lijdt. Het doel is dit lijden te verlichten. Er vond discussie plaats over dit verschil, de intentie. Voorbeelden passeerden de revue. De arts vertelde het verhaal van een patiënt waarbij niet de lichamelijke pijn op de voorgrond stond, maar het psychisch lijden, veroorzaakt door een psychiatrisch verleden van de patiënt. Om dat lijden te verlichten werd de patiënt gesedeerd. Ook in die situatie bleek het met name voor de familie moeilijk om het onderscheid tussen sedatie en euthanasie te zien en te begrijpen. Steeds, in alle voorbeelden en verhalen, resoneerde toch weer de oorspronkelijke vraag: 'Wat is het verschil...' 
Uit de reacties in de discussie rond deze vraag bleek dat zorgverleners de situaties waarop de vraag van toepassing was, moeiteloos konden reproduceren, inclusief wat dat voor henzelf als persoon betekende. 'Als het om een patiënt gaat van wie ik weet dat hij euthanasie heeft gevraagd, vind ik het moeilijker om de juiste dosering voor sedatie te berekenen en toe te dienen. Juist omdat de grens soms zo vaag lijkt', aldus een van de zorgverleners. De vraag bleef in de lucht hangen, het antwoord niet helemaal overtuigend omdat het in de concrete situaties die werden aangehaald toch steeds weer die vaagheid was die indruk maakte en vragen opriep.

Bij vraag twee riep de term zielenpijn veel discussie op. Ook hier was de herkenbaarheid groot. Echter psychische nood, de pijn van de ziel, is moeilijk meetbaar: 'Mensen geven dat over het algemeen niet duidelijk aan.' Als het om psychische of spirituele pijn gaat, gebruiken patiënten vaak beelden of symbooltaal (Van Orshoven, 1996; Prins, 1999). Deze signalen opvangen en juist interpreteren is moeilijk, te meer als de het spreken voor de patiënt fysiek niet meer goed mogelijk is. Daarom, zo kwam naar voren, is het altijd belangrijk je te verdiepen in de achtergrond van patiënten: 'Welke vermogens heeft men in het verleden opgebouwd om met problemen om te gaan?' Gesprekken met familie en informatie van de huisarts kunnen aanknopingspunten zijn om de uitingen van de patiënt te begrijpen. Ook in de literatuur over ethiek en palliatieve zorg wordt de discussie gevoerd. De onbehandelbaarheid van existentieel en emotioneel lijden lijkt moeilijker vast te stellen dan de onbehandelbaarheid van fysieke pijn en symptomen. Terminale sedatie om angst, verlatenheid of hopeloosheid weg te nemen zou een makkelijke uitweg betekenen voor een complex probleem (Janssens, 200I, p. I44; Janssens e.a., 2002, p.80, 81). De transparantie en aanwezigheid van heldere criteria die bij euthanasie vereist zijn, zouden aldus Janssens e.a. ook moeten gelden bij terminale sedatie.

Dat is ook de mening van de zorgverleners in het overleg. Naar aanleiding van de vraag over de zielenpijn werden ervaringen en aandachtspunten naar voren gebracht, die weer nieuwe vragen opriepen: 'Wanneer wordt besloten tot sedatie, moeten we dan niet veel meer en systematischer nagaan of we wel zorgvuldig genoeg handelen?' Sedatie is dan wel niet bedoeld om het leven te bekorten, vaak is dat wel het gevolg. Ook zal sedatie het bewustzijn zodanig verminderen, dat communicatie niet meer, of heel beperkt mogelijk is. Misschien heeft de patiënt nog laatste wensen, wil hij nog iemand zien of spreken. De belangrijkste punten die zorgverleners noemden waren: Nagegaan moet worden of de patiënt nog laatste wensen heeft; overleg met het multidisciplinaire team en met de huisarts; wees je bewust over welke pijn het gaat; de zielenpijn van de patiënt, of je eigen pijn als zorgverlener, en aandacht voor afscheidsrituelen. 
De stelling 'het laten slapen als alternatief aanbod voor mensen die euthanasie vragen', werd in eerste instantie afgewezen: 'zo mag je dat nooit noemen.' Opnieuw werden echter vragen opgeworpen, verbonden met eerdere ervaringen. 'Het blijft een heikel punt. Natuurlijk gaat het niet aan de pomp maar hoger te zetten om het leven te bekorten: het moet steeds om pijnbestrijding gaan.' Voor sommigen was het geen probleem de laatste dagen te bekorten, maar niet iedereen was het daarmee eens. De terminale fase is een breed begrip, het is een groot verschil, zo werd gezegd, iemand te sederen die nog rondloopt, of wanneer het gaat om de laatste dag(en).

De discussies werden afgerond om in een volgende bijeenkomst weer verder te gaan. In deze eerste bijeenkomsten stonden 'de zorgvraag herkennen' en 'verantwoordelijkheid' centraal. De eerste fasen van Tronto's beschrijving van een ethiek van zorg (Tronto, 1993). Aandachtigheid, zorg en verantwoordelijkheid zijn echter niet voldoende. $\mathrm{Er}$ is behoefte aan beleid waarin de verantwoordelijkheid en deskundigheid van zorgverleners tot uitdrukking kan komen. Een beleid dat aansluit bij de praktijk, en dat regelmatig kan worden geëvalueerd en ter discussie kan staan wanneer nieuwe en vergelijkbare zorgsituaties daarom vragen.

\subsection{Voorwaarden voor verantwoorde sedatie}

De vervolgbijeenkomst vindt plaats in april 2000. Opnieuw een multidisciplinaire samenspraak van zorgverleners en management. Een van de hospice-artsen volgt inmiddels aan de Universiteit van Cardiff in Wales de opleiding Palliative medicine. Zij maakt sedatiebeleid tot een van de speerpunten van haar studie. In het kader hiervan ontwerpt zij een vragenlijst om na te gaan welke regels en normen in het hospice ten aanzien van sedatie in de praktijk worden gehanteerd. Gedurende de periode februari tot en met maart wordt aan zorgverleners gevraagd deze vragenlijsten in te vullen in die gevallen waarin sprake is van sedatie. In deze bijeenkomst staat het resultaat hiervan op de agenda. Aan mij opnieuw de taak dit ethisch beraad voor te bereiden en te begeleiden.

Het blijkt dat in de periode februari tot half maart in het hospice 12 mensen zijn overleden. Acht van hen hebben sederende middelen gekregen. De vragenlijsten werden deels wel, deels niet ingevuld. In de praktijk bleek het er vaak niet van te komen extra tijd te investeren om, naast het normale rapportagesysteem, andere lijsten in te vullen. In de discussie hierover werd opnieuw stilgestaan bij de betekenis van sedatie. Wanneer spreken we eigenlijk van sedatie? Kunnen we er een definitie van geven? Als aandachtspunt werd de 
sederende werking van andere medicijnen genoemd, middelen die niet zijn ingezet om te sederen.

Definities werden met elkaar vergeleken (Schotsmans, 2000; Jonker, 2000), praktijkvoorbeelden passeerden de revue. Zorgverleners brachten criteria naar voren die zij terug wilden vinden in een definitie:

- Het niveau: sederen tot het niveau dat vereist is;

- Dat alle redelijke proportionele behandelingen zijn uitgeput;

- Dat het gaat om patiënten van wie het levenseinde zeer nabij lijkt.

Naast het definiëren van het begrip werd over normen gesproken, voorwaarden die belangrijk zijn voordat sedatie kan worden voorgesteld of ingezet. Ook hierbij hadden praktijkervaringen van de verschillende zorgverleners een belangrijke motiverende werking. Dit bleek uit de levendige discussie, waaraan iedereen deelnam. Veel nadruk werd gelegd op de cruciale rol van communicatie: communicatie met de patiënt, met andere zorgverleners, en met de familie. Niet alleen aan het begin, om op basis van informed consent tot een beslissing te komen, ook tijdens het proces blijft het afstemmen op de behoeften en wensen van de patiënt, de observaties van andere zorgverleners en familie van wezenlijk belang. Overeenstemming was er over het belang van nauwkeurige rapportage van de bevindingen, als één van de instrumenten om in dat proces de vinger goed aan de pols te kunnen houden. Hierbij werd opgemerkt, dat het dan ook goed zou zijn, om aan de hand van die registraties regelmatig te evalueren hoe de zorgprocessen verlopen zijn. Aparte formulieren echter, blijken in de praktijk niet te werken. Besloten werd dat moet worden gezocht naar inbedding in bestaande (rapportage-) systemen. Een actie die op het bordje van de onderzoeker werd gelegd. Tevens werd mij gevraagd om de in de discussie door zorgverleners naar voren gebrachte aanbevelingen en aandachtspunten, te interpreteren en herdefiniëren in een voorstel voor de normen en werkwijze in geval van sedatie. Dit als aanzet voor het gesprek in het volgend overleg. Hier werd een beroep gedaan op mijn rol van vertolker van de ervaringen en indrukken die de verschillende zorgverleners over de praktijk van de zorg en met name in het omgaan met moeilijke situaties als die van de heer Altena, in het overleg lieten horen.

Hoewel de fasen in het zorgproces te onderscheiden zijn, zijn ze niet geheel van elkaar te scheiden. Zo ook in dit beraad. Om gezamenlijk gedragen beleid te ontwikkelen was het belangrijk dat elke stem werd gehoord en ieder van de aanwezigen vrij was zijn of haar ideeën of zienswijze in te brengen. Een aandachtspunt voor mij als onderzoeker en begeleider.

Centraal in deze derde bijeenkomst stonden de vragen van zorgverleners: wat is sedatie? Welke normen zijn belangrijk? Hoe om te gaan met rapportage? 
Steeds werd teruggekoppeld naar de praktijk, de ervaringen, de vragen en problemen die deze deskundigen in de discussie inbrachten. Zoals ook in het zorgproces het inschatten van de zorgvraag en het daarop inspelen een voortdurend afstemmen inhoudt met degene waarom het gaat, met het oog op kwaliteit. Ook in die praktijk is zal niet altijd in één gesprek duidelijk zijn hoe verder te gaan. Het vervolg van het ethisch beraad wordt gepland in juni 2000 .

\subsection{Protocollen en registratie}

De intentie zorg te verlenen, zelfs de aanvaarding van verantwoordelijkheid daarvoor, maar dan te kort schieten in kwaliteit, betekent uiteindelijk dat men er niet in is geslaagd deze intenties waar te maken (Tronto 1993, p.133). Het ethisch beraad van juni werd afgeblazen. Er was teveel aan de hand: drukte in het hospice, mensen met vakantie, het management niet compleet aanwezig. Kortom, voldoende reden om de bijeenkomst naar een later tijdstip te verplaatsen. Voor mij was dat een teleurstelling: Er was hard gewerkt, we waren al een eind op weg, was er dan toch niet voldoende animo? Was ethiek toch niet zo belangrijk als men zei? Of zag ik het proces te veel als mijn persoonlijke verantwoordelijkheid, mijn missie die moest slagen? Wilde ik het proces toch mijn richting op sturen? Ik realiseerde mij echter dat responsiviteit van de methode nu juist betekent de ander serieus nemen. Ook al lijken sommige uitingen tegendraads ten opzichte van intenties en verwachtingen. Ik besloot rustig af te wachten, het IZO te blijven volgen, aanwezig te blijven in de praktijk. Beleidsbeslissingen vragen om voldoende draagvlak. Belangrijke beslissingen nemen met een handjevol mensen zou voorbijgaan aan de intenties van responsief beleid.

In de tussenliggende tijd maakte ik me nuttig door het initiëren van overleg. zoeken naar mogelijkheden van het registratiesysteem: welke vormen van registratie sluiten het best aan bij de gangbare dagelijkse verslaglegging van patiëntengegevens door zorgverleners? Er was overleg met het hoofd van de zorgverlening en met de interne systeembeheerder (computersysteem). De opties die besproken werden waren:

I. Sedatie van terminale patiënten wordt opgenomen in het protocollenboek $^{10}$.

10 Een protocollenboek is een voor zorgverleners toegankelijk naslagwerk, waarin werkwijze voor regelmatig terugkerende handelingen en daarop betrekking hebbende situaties zijn neergelegd. 
2. Het computersysteem wordt zodanig aangepast, dat er ruimte ontstaat voor een apart venster Sedatie. Hierin wordt een vaste vragenlijst opgenomen. Bij dagelijkse rapportage van patiëntgegevens, die per computer plaatsvindt, hoeven dan weinig extra handelingen te worden verricht.

3. Toch een aparte vragenlijst, maar dan niet groter dan een A-4, op nemen in het patiëntendossier.

Deze opties werden in het verpleegkundig overleg ${ }^{\text {II }}$ in augustus besproken. Daar koos men in eerste instantie voor geautomatiseerde verslaglegging, met de computer dus. Men moest op dat besluit terugkomen, omdat het systeem niet gebruiksvriendelijk genoeg bleek. In de toekomst, wanneer de mogelijkheid zich voordoet het systeem aan te passen, wil men daarop alsnog overgaan. Besloten werd om met de vragenlijst in het patiënten dossier te gaan werken. De voorlopig afgesproken werkwijze sedatiebeleid werd in het protocollenboek opgenomen.

In september 2000 vond het vervolg van het beraad plaats.

\subsection{Verslaglegging sedatie voorvallen}

De bijeenkomst van september betekende een afronding van het sedatiebeleid en luidde daarmee ook een afronding van het veldwerk in het hospice in. In dit overleg werd het verslag van de definitie van sedatie, het beleid en de werkwijze, vastgesteld in eerdere besprekingen, systematisch doorgenomen om eventueel aan te passen en tot overeenstemming te komen.

Afspraken moesten worden gemaakt ten aanzien van de verslaglegging. Vragen daarbij waren: Wat zijn de ervaringen tot nu toe? Wordt het al in werking gezette protocol geëvalueerd na elk overlijden (in geval van sedatie)? Ontbreken er belangrijke aandachtspunten? Hoe zou verslaglegging moeten worden aangepast? Of gaat het goed zo? Wat vindt men van een evaluatie na ongeveer drie maanden?

De definitie, waarover overeenstemming werd bereikt luidt:

Sedatie is: Het toedienen van medicamenten met een sederende werking met als doel het verlichten van het tot dusver therapieresistent lijden, (waarbij alle andere mogelijkheden die bekend zijn te kort schieten) door verlaging van het bewustzijn tot het niveau dat vereist is voor een adequate lijdensverlichting.

Ten aanzien van de norm, de aandachtspunten en de werkwijze werd het volgende vastgesteld:

11 Verpleegkundig-overleg is een maandelijks overleg tussen verpleegkundigen over procedures en ervaringen. 
Sedatie kan worden toegepast bij therapieresistent lijden: Onbehandelbare pijn, ernstige vormen van misselijkheid en braken. Ook angst en onrust, ook geestelijk lijden dat niet reageert op de aangeboden therapie valt hieronder.

De beslissing om tot sedatie over te gaan dient, indien mogelijk, in multidisciplinair verband te worden genomen. De mate van sedatie zal afhangen van de mate van lijden. Indien een lichte mate van sedatie voldoende is, zal de patiënt nog een zekere mate van bewustzijn behouden, cq. in staat zijn tot communicatie met zijn of haar omgeving. Naarmate zwaardere vormen van sedatie noodzakelijk zijn om het lijden te verlichten, zal de mogelijkheid tot communicatie ophouden. Wanneer de patiënt door de sedatie volledig buiten bewustzijn is geraakt, zal hij of zij niet meer in staat zijn vocht of voedsel tot zich te nemen. In dit geval kan de sedatie een bespoediging van de dood tot gevolg hebben.

1. Overeenstemming was er over interdisciplinair overleg als eerste belangrijke uitgangspunt voor sedatie. Bij het vaststellen van sedatiebeleid zijn steeds verschillende disciplines betrokken. In het hospice waar het overleg plaatsvond zijn dat bijvoorbeeld in ieder geval de arts(en), verpleegkundigen, en de pastoraal werker. Afhankelijk van de patiënt en de situatie, mogelijk aangevuld door overleg met andere disciplines.

Voorstel, effecten en reikwijdte van de sedatie dienen met patiënt en zijn of haar directe naasten te worden besproken. Dit gesprek vindt bij voorkeur plaats door de arts in aanwezigheid van een verpleegkundige. Dit omdat het gaat om een medische handeling, waarbij de verpleging een belangrijke rol speelt in de verdere uitvoering en begeleiding. In acute situaties, 's nachts of in het weekeinde, kan het voorkomen dat de arts voor dit gesprek niet beschikbaar is. De dienstdoende verpleegkundige neemt in een noodsituatie niet zelf het besluit tot sedatie, dit moet steeds van te voren besproken zijn. Met andere woorden, er moeten afspraken zijn gemaakt over hoe te handelen in een noodsituatie. Dit beleid moet helder zijn. Bovendien moet een arts altijd te raadplegen zijn, ook's nachts.

Ook kan het voorkomen dat er nauwelijks tijd is voor een gesprek of voor het geven van informatie aan de patiënt en zijn naasten. In dat geval is het geoorloofd achteraf deze informatie te verstrekken. Deze noodsituaties zo veel mogelijk van te voren inschatten is belangrijk om te voorkomen dat het van te voren informeren van patiënt en familie erbij inschiet.

Belangrijke aspecten die volgens zorgverleners in het gesprek aan de orde dienen te komen, zijn:

- Het doel, de intentie van de sedatie: verlichting van het lijden. De diepte van de sedatie hangt samen met het effect ervan op de klachten; 
- Verschillen met euthanasie. Intentie en doel verschillen van euthanasie. Niet alleen voor de patiënt, maar vooral ook voor familie, de directe naasten, is het belangrijk uit te leggen wat er gebeurt, wat mensen kunnen verwachten en wat het verschil is met euthanasie. In sommige gevallen kan het juist bedreigend zijn de term euthanasie te noemen. Indien dit aspect niet besproken wordt met de patiënt en zijn of haar familie, dan is het belangrijk dit schriftelijk te registreren: 'niet over verschil met euthanasie gesproken';

- Overleg over de mogelijkheid de medicatie intermitterend toe te dienen: bijvoorbeeld in dag- en nachtritme;

- Bespreken van neveneffecten, de bijwerkingen: minder of geen communicatie meer mogelijk, minder of geen drinken en/of eten verkort het leven.

Op basis van dit gesprek dient er sprake te zijn van 'informed consent'; patiënt en/of eerste contactpersoon weten waar zij voor kiezen en aanvaarden de consequenties.

2. Voordat de sedatie wordt ingezet, zal worden nagegaan in hoeverre patiënt en/of directe naasten behoefte hebben aan bepaalde rituelen, een gesprek met een geestelijk begeleider, het sacrament van de zieken, een biecht, of andere zaken. De sedatie zal het bewustzijn verlagen en dus de communicatie op z'n minst bemoeilijken. Wellicht wil de patiënt, voordat het zover is, nog afscheid nemen van bepaalde dierbaren, wachten op de overkomst van familie of vrienden. Het is van belang hiervoor de ruimte te bieden als dat enigszins mogelijk is.

3. Bij de feitelijke start van de sedatie, meestal door de verpleegkundige, is het van belang nogmaals stil te staan bij de vraag of de patiënt nog steeds achter de beslissing tot sedatie staat. Een controle op informed consent dus.

4. Gedurende de sedatie dient regelmatig te worden geobserveerd en gecontroleerd of de toegediende medicamenten het gewenste effect hebben. Tenminste eenmaal in elke dienst gaat de verpleging na of de symptomen, die aanleiding vormden voor de sedatie nu afwezig zijn, of teruggebracht tot een draaglijk niveau. Hiervan wordt schriftelijk verslag gedaan, ook als alles is zoals het was bedoeld. Wanneer sedatie onvoldoende effect heeft, dient te worden overlegd met de dienstdoende arts over aanpassing van de medicatie. Dit overleg met de arts wordt ook schriftelijk vastgelegd, ook als is besloten om de arts niet te raadplegen.

5. Wanneer de aanpassing van de medicatie de tevoren afgesproken reikwijdte overschrijdt, dient opnieuw te worden overlegd met de patiënt of met de eerste contactpersoon. Dit overleg dient ook geregistreerd te worden. 
6. Norm-evaluatie: na overlijden van de patiënt altijd de norm toetsen: hoe is het proces verlopen, zijn alle aspecten van de norm steeds aan de orde geweest, is observatie van de patiënt en verslaglegging steeds voldoende en adequaat geweest, was de communicatie met team en familie in orde?

\subsubsection{Terugkerende vragen in het overleg}

Discussie ontstond opnieuw over wanneer nu precies van sedatie wordt gesproken. Verpleegkundigen vinden dat het in de praktijk niet altijd even duidelijk is wanneer het over sedatie gaat of over nog behandelbare symptoombestrijding.

Afgesproken werd ${ }^{12}$ :

- Van sedatie wordt gesproken als het de bedoeling is te sederen;

- De arts schrijft voor, de arts is steeds degene die in voorkomende gevallen moet aangeven dat het om sedatie gaat;

- Bij twijfel (juist in die grensgebieden waar over symptoombestrijding wordt gesproken) moet de verpleegkundige de arts vragen: 'Wat zijn we aan het doen? Is dit sedatie?'

- Gaat het om sedatie in de laatste paar uur van het leven van de patiënt, dan is het protocol niet van toepassing

Steeds weer in het overleg kwam de vraag naar voren wanneer precies van sedatie wordt gesproken. Ondanks het gezamenlijk definiëren van het begrip en terugkerende uitleg over het verschil met symptoombestrijding en euthanasie. Zorgverleners geven aan dat de praktijk vaak toch niet zo duidelijk is. Pijnbestrijding, verandering, verhoging van middelen heeft vaak een sederende werking zonder dat in al die situaties wordt gesproken of gesproken zou moeten worden van terminale sedatie. Als patiënten zijn overleden stelt men zich achteraf soms de vraag, was dit nu sedatie of niet? Blijkbaar is niet alleen de grens tussen euthanasie en sedatie vaag, ook tussen adequate pijnbestrijding en sedatie lijkt een schemergebied te bestaan.

Gezegd werd dat het verschil zit in de bedoeling, de intentie waarmee sedatie wordt ingezet. Een verschil volgens Nuij en Hoogerwerf (2000) tussen laten van medicamenten met een sederende werking, met als doel het verlichten van het tot dus. ver therapie resistent lijden, (waarbij alle andere mogelijkheden die bekend zijn te kort schieten) door verlaging van het bewustzijn tot het niveau dat vereist is voor een adequate lijdensverlichting. 
sterven en doen sterven, uiterst vaag dus menen zij. Zij refereren aan eerdere discussies in de medische ethiek over het zogenaamde 'dubbel effect', waarbij ervan wordt uitgegaan dat de lijdensverlichting het goede en het mogelijk eerder sterven, het slechte effect is. Zij noemen de argumentatie waarin het slechte effect van de handeling wordt geaccepteerd omdat het goede effect ervan groter is, 'ethische acrobatie' en wijzen dat af. Zij komen tot de conclusie dat het begrip 'intentie' als moreel motief onhanteerbaar en overbodig is als legitimatie van het medisch handelen. 'Wanneer besloten wordt tot terminale sedatie, dan heeft dat slechts één betekenis: er is geen ander normaal medisch handelen meer effectief om het lijden te verminderen of op te heffen. Het is als het ware de bodem van palliatieve zorg' (Nuij en Hoogerwerf, 2000, p. 123). Wat terminale sedatie tot buitengewoon medisch handelen maakt, is dat de inzet ervan meestal gepaard gaat met dehydratie: de patiënt kan in gesedeerde toestand niet drinken, krijgt geen vocht toegediend en zal daardoor eerder komen te overlijden. Op die manier is er eigenlijk geen (moreel) verschil tussen euthanasie en sedatie. Ook euthanasie is buitengewoon medisch handelen, een handelen dat in de wereld van de palliatieve zorg veelal wordt afgewezen ${ }^{13}$. Janssens (200I, p. 142); Janssens e.a., 2002) gaan hierop in en beargumenteren de morele aanvaardbaarheid van het eventueel eerder overlijden (slecht effect van sedatie) en de morele ongelijkwaardigheid van euthanasie en terminale sedatie aan de hand van regelethische criteria:

- De handeling zelf moet moreel goed of ten minste moreel neutraal zijn;

- De handelende persoon mag het slechte effect niet beogen, maar mag dit slechts tolereren. Indien het goede effect bereikt kan worden zonder dat het slechte effect optreedt, moet de handelende persoon zo handelen;

- Het goede effect moet direct door de handeling worden veroorzaakt;

- Het goede effect moet voldoende gewenst zijn om te compenseren voor het optreden van het slechte effect.

Het geîntendeerd doden (euthanasie) wordt gezien als prima facie moreel slecht, het toedienen van sederende middelen om het lijden te verlichten dient hiervan te worden onderscheiden aldus deze auteurs. De intentie is volgens deze principes relevant voor de moraliteit van de handeling. Beaamd wordt dat dit een grond kan zijn voor vaagheid en misverstanden. Intenties zijn moeilijk

13 In de oorspronkelijke hospice-beweging werd (en wordt) euthanasie uitgesloten. 'De dood uitstellen noch versnellen', is daar het uitgangspunt. In het recent verschenen Handboek palliatieve zorg (Maarssen, 2002) wordt afstand genomen dat het idee dat euthanasie en palliatieve zorg elkaar zouden uitsluiten. 'Binnen een goede palliatieve zorg kan euthanasie als mogelijkheid zeker aan de orde komen' (Dekkers, 2002 p. 73). 
te controleren en ook kunnen er meerdere intenties naast elkaar bestaan: zowel de intentie om het lijden te verzachten als de intentie om de dood te bespoedigen. Dit is echter een onvoldoende argument om te zeggen dat intenties er niet toe doen. Er is toch een vorm van controle mogelijk, namelijk door te kijken naar de aard van de handeling: Verhouden de middelen zich tot het doel? 'Het voortdurend ophogen van morfine-dosis zonder de diepte van de sedatie en de conditie van de patiënt in acht te nemen zou niet overeenstemmen met de intentie van sedatie en zou dan inderdaad gelijk zijn aan euthanasie, waarvoor wettelijk vastgelegde zorgvuldigheidscriteria in acht genomen dienen te worden' (Janssens, 2002, p.80). Sedatie zou in dit geval een schijnoplossing zijn voor euthanasie. Ook het argument van dehydratie, als zou dat bijzonder medisch handelen zijn vergelijkbaar met euthanasie, wordt van de hand gewezen met een beroep op het oorspronkelijke uitgangspunt van palliatieve zorg de dood noch te willen bespoedigen, noch te willen uitstellen: 'Dehydratie dient opgevat te worden als het afzien van een levensverlengende handeling. Kunstmatige toediening van vocht (in terminale fase) kan een aantal nadelige gevolgen hebben en wordt binnen de palliatieve zorg beschouwd als ongewenst medisch handelen. Slechts in een klein aantal gevallen is vochttoediening gerechtvaardigd evenals het onderbreken van sedatie bijvoorbeeld wanneer de patiënt levensverlenging van belang acht om van mensen, bijvoorbeeld familie uit het buitenland, afscheid te kunnen nemen (Janssens e.a. 2002, p. 81; Broeckaert en Núnez, 2002).

Deze discussie uit de literatuur vindt een voedingsbodem in een praktijk, waar pijnbestrijding en bijwerkingen daarvan, sedatie en de vraag om euthanasie zorgverleners doen worstelen met de confrontatie met die soms dunne grens tussen gewenst en ongewenst, tussen moreel aanvaardbaar en niet aanvaardbaar handelen. Uitmondend in de terugkerende vraag die in het overleg steeds opklonk: wanneer precies is of was er sprake van sedatie?

\subsubsection{Registratie}

Overeenstemming was er over het belang van registratie. Registratie komt tegemoet aan de behoefte aan transparantie van criteria en van intenties ten aanzien van terminale sedatie. Een norm als richtlijn voor zorgvuldig handelen in geval van sedatie van terminale patiënten staat of valt met een zorgvuldig omgaan met en registreren van zaken die zijn afgesproken. Een zorgvuldigheid die in relatie gezien kan worden met het concept van responsiveness, maar waarvoor tegelijk een belangrijke voorwaarde ontbreekt. Tronto's morele concept van responsiveness impliceert een actieve rol van degene die zorg ontvangt. 
Van een actieve inbreng van de patiënt in gesedeerde toestand kan echter geen (of nauwelijks) sprake zijn.

Het is heel moeilijk de praktijk in een keurslijf van een protocol te passen. De praktijk, de individuele situaties en onverwachte gebeurtenissen spelen hun rol en laten hun sporen na. Daarom is de omgekeerde beweging ook belangrijk: de spiegeling, steeds opnieuw, van de praktijk aan de norm, aan het vastgelegde en overeengekomen protocol. Nieuwe ervaringen kunnen hier nieuwe elementen aan toevoegen. Op die manier wordt dat protocol een levend instrument voor zorgvuldig en professioneel handelen en blijft het bijdragen aan kwaliteit van zorg. Registreren wat er is gebeurt, is daarbij van grote betekenis. Zonder het vastleggen van feiten is het vaak moeilijk achteraf te bepalen wat er precies is gezegd, wie geïnformeerd of geraadpleegd is en hoe de patiënt reageerde op de behandeling.

Het voorstel om regelmatig het beleid te evalueren werd gesteund. Een periode van drie maanden was te kort. Na een half jaar terugblikken, leek een betere optie. Initiatieven daartoe zouden de verantwoordelijkheid zijn van management en zorgteam.

Dit vierde overleg betekende een afronding van de groepsbijeenkomsten. Bijeenkomsten die, geïnitieerd door het management, op uitdrukkelijk verzoek van zorgverleners werden georganiseerd. De motivatie van zorgverleners droeg bij aan een proces waarin deelnemers actief bijdroegen aan de discussies die werden gevoerd. Zowel management als zorgverleners gaven aan de discussies als zeer zinvol te ervaren.

\subsection{Follow-up, beleid in de praktijk}

Hoewel het veldwerk al enige tijd was afgesloten, bezocht ik half januari 2001 het hospice opnieuw met de vraag hoe het beleid in de praktijk verliep. Ik kreeg de gelegenheid om patiëntendossiers, waarbij sprake was van sedatie te bestuderen om te zien hoe het proces was verlopen. In een van de drie situaties werd volgens protocol het formulier dagelijks ingevuld. Desondanks werd in die situatie de familie (te) laat geīnformeerd over aanpassing van de medicatie. In de andere twee dossiers bleef registratie achter en was bovendien in een van die situaties niet duidelijk of het eigenlijk wel om sedatie ging. Niet goed kon worden nagegaan in hoeverre recht werd gedaan aan de morele kwaliteit van responsiveness.

De evaluatie riep een aantal vragen op. Enerzijds inhoudelijke vragen, die ik met de evaluatie aan het management toestuurde, maar ook vragen ten aanzien van het proces van beleidsontwikkeling dat ik in het voorafgaande jaar had 
begeleid. Het ging om knelpunten die in de gesprekken over het beleid steeds weer opnieuw werden ingebracht, zoals de vraag: 'Wanneer spreken we nu eigenlijk van sedatie?' een vraag die samenhangt met het soms moeilijke onderscheid tussen pijnbestrijding en inzet van middelen voor de sederende werking ervan. Uit de beperkte registratie bleek dat de voorgestelde manier van verslaglegging niet goed werkte. In twee van de drie dossiers stellen verpleegkundigen vragen bij het gevoerde beleid en wordt de wens neergelegd dit binnen het team te evalueren.

\subsection{Moreel beraad}

Hoewel de uitkomst van deze follow-up mij prikkelde om met de praktijk in gesprek te blijven, nieuw (vervolg van) overleg voor te stellen en verder te praten, bleef het hierbij. En ik zoek naar antwoorden op de vraag waarom toch steeds de regelethiek domineert in het omgaan met vragen die voortkomen uit zorgethische betrokkenheid, vragen die tegen de systeemdruk in worden gesteld. Terugkijkend op de hele discussie over sedatie vraag ik me af of het niet te veel een technische discussie is geworden, waarin het vooral ging om het onderscheid pijnbestrijding, sedatie, euthanasie. In dat opzicht lijkt de praktijk een afspiegeling van de theoretische beschouwingen met betrekking tot sedatie en euthanasie. Ook daar gaat het om argumenten over de medische noodzaak of morele laakbaarheid van wel of niet toedienen van vocht. En over de vraag of de intentie, de bedoeling waarmee tot sedatie wordt besloten, van invloed is op de morele status van de handeling. Om aan te geven dat de grens tussen euthanasie en sedatie flinterdun, bijna verwaarloosbaar is. De patiënt, de heer Altena en zijn complexe zorgsituatie, verdwijnen uit het zicht. Om de zorgethiek meer kans te geven zou de concrete situatie meer in beeld moeten blijven. Dit kan door bijvoorbeeld de vragen die in het overleg naar voren komen te blijven verbinden met die zorgsituatie, die aanleiding was voor de samenspraak.

Het is interessant dit te relateren aan de ervaringen en lessen uit het IZO. In dat wekelijks overleg ging het niet enkel om ethische aspecten. Maar wanneer ethische vragen opklonken waren deze steeds verbonden met concrete situaties en de zorg voor individuele patiënten. Juist in die concrete situaties krijgen regels nieuwe betekenis of kan herziening van die regels ter sprake komen (Nussbaum, 1998, p.20). Beleid, protocollen en regels staan verder af van de concrete werkelijkheid, die zich in zoveel verschillende situaties voordoet. Het zijn belangrijke, zelfs noodzakelijke hulpmiddelen voor het handelen in het algemeen, maar vragen om interpretatie per situatie, aldus Nussbaum.

Dat in ethische discussies in het IZO en in de schriftelijke reacties op de vra- 
gen uit de praktijkverhalen de regelethiek vaak de doorslag geeft, is deels te begrijpen uit het houvast dat regels en principes bieden. In een rationele afweging wordt duidelijk hoe te handelen. In crisissituaties is het vaak ook van belang handelend op te treden, te weten wat moet worden gedaan. De principebenadering sluit aan bij de systeemwereld, die anders dan de beleefde ervaringen, een rationele werkelijkheid vertegenwoordigt. Ook traditie speelt een rol. De medische ethiek is van oudsher verbonden met het hippocratisch uitgangspunt van weldoen en niet schaden, waarbij in de beoordeling van wat juist en goed is een belangrijke rol is weggelegd voor de medicus. De ontwikkelingen van de moderne tijd hebben autonomie, het zelfbeschikkingsrecht van patiënten een zwaar accent gegeven.

Ondanks die systeemdruk lijkt in het IZO toch meer ruimte te zijn voor de beleving, de emoties en vragen die in concrete ervaringen een rol spelen. Meer dan in de bijeenkomsten over sedatiebeleid. Daar verdween de concrete ervaring die aanleiding was voor het overleg naar de achtergrond. Een moreel beraad zoals Verkerk (2000) bepleit, vraagt dan ook niet alleen een communicatief klimaat waarin de verschillende perspectieven ruimte krijgen voor reflectie en overleg in het zoeken naar wat juist en goed is in moeilijke situaties. Net zo belangrijk is het dat die situaties in de discussie centraal blijven staan. Juist in de concrete ervaringen komt de kwetsbaarheid van individuen (zorgverleners én patiënten) aan het licht en krijgt de spanning tussen systeem en leefwereld woorden in vragen die daaruit opklinken. Trage vragen zoals Kunneman (1999) ze noemt, die steeds weer opborrelen en oproepen tot reflectie. De mogelijkheid die het IZO biedt spontaan ethische vragen of ervaringen in te brengen, komt hieraan tegemoet. Hierdoor ontstaat ruimte voor emoties en kwetsbaarheid, ruimte om zich in te leven in het verhaal dat verteld wordt over concrete ervaringen en het effect daarvan op mensen.

Ik denk terug aan het verhaal waarmee het boek begint, de moeilijke laatste levensperiode van mijn oude vriend. Vragen rond het levenseinde gaan altijd over kwetsbaarheid. Het zijn existentiële vragen waar vaak geen definitief antwoord op is. Regels en protocollen geven houvast, maar geen antwoord op die kwetsbaarheid.

\author{
De grijze medebroeders \\ mijden het lijden \\ in hun midden, \\ zachtjes schuifelen zij \\ er aan voorbij, \\ de ogen neergeslagen
}


als in bidden

om het angstig voorgevoel

van wanneer treft het mij.

De snelle ontwikkelingen in de (medische) wetenschap en medische mogelijkheden, hebben in de Westerse wereld bijgedragen aan een groeiende behoefte om alles als beheersbaar en oplosbaar te beschouwen. Problemen die niet te overzien zijn, werden tot kleine stukjes verbrokkeld, tot kleine problemen die wel oplosbaar zijn (The, 1997a, p.277). Wat blijft liggen zijn de diepste vragen, verbonden met kwetsbaarheid, eenzaamheid. Vragen voorbij techniek, over zin van leven en lijden. Misschien hebben we dan allemaal wel de neiging om het hoofd te buigen. Misschien is dat beter dan met regels en protocollen in de hand en steunend op de retoriek over een al dan niet zachte dood, te denken op die manier uiteindelijk alle antwoorden vinden. De zorgethiek biedt handvatten hoe het anders kan. Tegelijk is het geen panacee tegen alle spanning die de dwang vanuit de systemen uitoefent op leefwereldervaringen en behoeften. Zorgethiek kijkt niet zozeer naar de, ook noodzakelijke, regels van de organisatie en het systeem waarvan die deel uitmaakt, maar naar de behoeften van het individu. Zij vraagt niet alleen aandacht voor rationele maar ook voor existentiële vragen en emoties. Door dit perspectief meer ruimte te bieden, kan de complexiteit van de palliatieve zorg meer zichtbaar worden gemaakt. Zorgverleners en patiënten maken deel uit van het systeem. Tegelijk hebben zij eigen levensopvattingen, eigen emoties en waarden. Zij zijn de schakels tussen systeem en leefwereld.

Communicatie en reflectie kunnen bijdragen aan kwaliteit van zorg, maar even belangrijk is het zich te realiseren dat lang niet alles (met woorden) kan worden gezegd. Waar woorden niet wenselijk of mogelijk zijn, beschikken mensen over vermogens te zoeken naar andere bronnen, andere vormen om contact te leggen met elkaar en in steeds wisselende zorgsituaties af te stemmen op de zorgvragen van patiënten binnen een team van zorgverleners.

\author{
Ontelbaar dunne rimpels \\ diep gekerfd in zijn gezicht \\ dat zelfs slapend \\ zo vol droefheid is. \\ Gewonde, dunne handen \\ zoeken stuurloos in de lucht, \\ hij heeft geen woorden meer \\ voor ons, alleen zijn aanblik \\ en die zucht.
}


Het resultaat van het onderzoek waarin het gesprek centraal stond, is bescheiden. Het is de bedoeling en de verwachting dat de ervaringen en beschreven processen uit de onderzochte praktijk herkenning zullen oproepen in andere zorgpraktijken. Dit herkennen kan aanleiding zijn in de eigen praktijk het gesprek voort te zetten in het streven naar kwaliteit van zorg waarin ethiek een vanzelfsprekende plaats heeft.

\subsection{Samenvatting}

In horizontale kwaliteitszorg worden alle regelingen, afspraken en procedures, die voor een goed functionerend kwaliteitssysteem noodzakelijk zijn, zo veel mogelijk ingebed in relaties, die communiceren op basis van gelijkwaardig. heid, betrokkenheid en openheid voor de waarde en inbreng van de ander (Kunneman, 1998, p.127). In dit hoofdstuk werd een dergelijk proces beschreven. Beschreven wordt hoe aan de hand van een zorgsituatie die voor verschillende zorgverleners erg moeilijk was, in een gezamenlijk communicatief proces nieuw beleid werd ontwikkeld. Het proces nam, verspreid in de tijd, bijna een jaar in beslag. Dat een dergelijk communicatief proces, waarin management en zorgverleners samenwerken, ook gezien kan worden als een zorgproces blijkt uit de onderscheiden fasen: aandachtigheid, verantwoordelijkheid, deskundigheid en responsiveness. Er kunnen vraagtekens worden geplaatst bij de kwaliteit van de communicatie. Hoewel de sfeer open was, en er volop gelegenheid werd geboden voor uitwisseling van standpunten, ervaringen en deskundigheid, bepaalden regelethische argumenten de richting van het beleid. De vaagheid van de grens tussen pijnbestrijding en sedatie en tussen sedatie en euthanasie werd niet volledig opgehelderd. Tegelijk nam dat onderwerp, de grens tussen het een en het ander, in het overleg de meeste ruimte in. Het bleek een steeds terugkerende vraag van (verpleegkundige) zorgverleners in het overleg. Om criteria en inhoud van sedatie zo transparant mogelijk te maken, werd het van belang geacht afspraken te maken over registratie van afspraken, afstemmen en aanpassen van medicatie wanneer tot sedatie wordt besloten. In een eerste evaluatie van beleid bleek zowel ten aanzien van registratie als ten aanzien van de vraag wanneer het nu precies om sedatie gaat, onduidelijkheid. De zorgethische vragen van waaruit het overleg gestart was, werden regelethisch opgelost. De verklaring van de constatering dat regelethiek domineert, moet deels worden gezocht in de in de moderne tijd gegroeide behoefte om alles als beheersbaar en oplosbaar te beschouwen. De snelle ontwikkeling van de medische wetenschap heeft daaraan ook bijgedragen. Daarnaast bieden regels en protocollen houvast in moeilijke situaties. De daar- 
mee verbonden rationele benadering, het afwegen van in geding zijnde principes, verdringt zorgethische aspecten die meer met de leefwereld en relationele betrokkenheid zijn verbonden. In het proces van beleidsontwikkeling verschoof de concrete zorgsituatie die aanleiding was voor het overleg, naar de achtergrond, waardoor de discussie meer en meer werd toegespitst op het vastleggen van regels en protocollen. Voor een moreel beraad waarin juist de concrete ervaringen centraal staan, biedt het IZO een beter klankbord.

Het ontwikkelen van sedatiebeleid was tevens afronding van het onderzoek. 



\section{Slotwoord en samenvatting}

Ik zou je zachtjes

op een wolkje willen leggen

dan hield ik je nog even bij de hand

en als je wegvoer

hoefde je niets meer te zeggen,

ga dan maar snel

naar het beloofde land.

Beneden zie je ons

nog even blijven.

het is wat stiller hier,

dat doet een beetje pijn

maar kijkend naar de

witte wolken weet ik

dat je er tegelijk ook nog zult zijn.

Ik zal het dan ook vast niet kunnen laten

zo nu en dan nog eens met je te praten.

In de voorgaande hoofdstukken is een beeld geschetst van een palliatieve zorgpraktijk. Met name werd stilgestaan bij de ethische dimensie daarvan. Het begin van het boek, tevens begin van mijn zoektocht, was een concrete zorgsituatie. Een persoonlijke ervaring waarin zorgbehoefte en fysieke afhankelijkheid stuitten op muren van onbegrip en rancune. Een situatie waarin de weg naar kritische zelfreflectie leek geblokkeerd waardoor de bewoner, tevens patiënt, maar ook de betrokken zorgverleners, in een isolement verkeerden. Een situatie die bij sommigen diepe emoties losmaakte, anderen min of meer onberoerd liet.

Om de praktijk inzichtelijk te maken en concrete situaties te verhelderen, werden theoretische perspectieven ingezet. De spanning tussen systeem en leef- 
wereld en de drive van mensen om de morele uitgangspunten herkenbaar en bespreekbaar te houden, werden beschreven en aan de hand van praktijkvoorbeelden uit de palliatieve zorg geconcretiseerd. De verschillende benaderingen van zorgethiek en regelethiek werden voor het voetlicht gebracht en gerelateerd aan de genoemde systeem - leefwereld spanning. Doel van het onderzoek was een bijdrage te leveren aan de praktijk en de theorie van de palliatieve zorg door het beschrijven en verhelderen van ethische probleemsituaties in praktijk van de palliatieve zorgverlening en het zoeken naar handreikingen voor mensen die hiermee te maken hebben. Gezocht werd naar vormen van communicatief overleg en ethische reflectie die een bijdrage leveren aan de kwaliteit van de palliatieve zorg en aan het veiligstellen en verder ontwikkelen van de eigenheid van deze zorg.

In dit slotwoord zal ik stilstaan bij wat het onderzoek en de wijze van benadering heeft opgeleverd. Daarbij zal worden ingegaan op hoe de theoretische perspectieven: maatschappijtheorie, ethiek en grondslagentheorie hebben bijgedragen om de praktijk inzichtelijk te maken en de spanning waar zorgverleners in die praktijk mee worden geconfronteerd te verhelderen. Ook zal worden ingegaan op de responsieve methode en de mogelijkheden die deze methode biedt om met de praktijk in gesprek te gaan.

\section{Systeem-leefwereld spanning in palliatieve zorg}

De ontwikkeling van wetenschap en techniek in de moderne tijd, die gepaard ging met steeds verdergaande specialistische kennis en praktijken, heeft geleid tot subsystemen met hun eigen taal en rationaliteit, waarin het alledaagse, de vanzelfsprekende leefwerelddimensie, nauwelijks toegang heeft. Belangrijke en ingrijpende levenservaringen waar mensen mee worden geconfronteerd, zoals handicaps, ziekten en sterven, raakten uit het zicht door de ontwikkeling van specialistische voorzieningen met eigen kennis, met regels en opvattingen om die voorzieningen in stand te houden en verder te ontwikkelen. Het delen en uitwisselen van ervaringen en gevoelens over wat het betekent te worden geconfronteerd met die bestaansknopen werd minder vanzelfsprekend en het praten over gevoelens en zingeving geïnstitutionaliseerd. Mensen leerden deze te verwoorden in de taal van het vakgebied van hulpverleners en voor oplossingen werd gekeken naar de technische mogelijkheden en bureaucratische voorzieningen (Habermas, 1987; Begeman, 1995; Kunneman, 1999; Giddens, 200I). Secularisering en ontkerkelijking als gevolgen van individualisering en de rationaliseringsprocessen van de moderne tijd droegen ertoe bij dat collectieve antwoorden op zingevingsvragen en emotionele gebeurtenissen minder 
toereikend of beschikbaar werden. Hoewel genoemde ontwikkelingen hebben bijgedragen tot emancipatie, bevrijding van op hiërarchie berustende vormen van onderdrukking en macht, creëerden ze ook een vacuüm door onmacht en gebrek aan gemeenschappelijke kaders om te reflecteren op die leefwereldimensies.

De ontwikkeling van de palliatieve zorg in Nederland, maar uiteraard ook elders in de wereld, is te begrijpen als tegenbeweging van mensen uit de gezondheidszorgpraktijk, humanistische en religieuze organisaties die zich niet langer konden vinden in de zorg voor stervenden in ziekenhuizen. Waar het accent in ziekenhuizen lag op behandelen en genezen, werd er in de palliatieve zorg voor gepleit zorg en kwaliteit van leven centraal te stellen. Zorg, niet alleen gericht op de fysieke aspecten maar een 'totale zorg', waarin gelijkwaardige aandacht is voor emoties, zingeving en sociale aspecten.

In kleinschalige zorgvoorzieningen als hospices en 'bijna-thuishuizen' werd deze zorg geboden en verder ontwikkeld. Hoewel ontstaan uit onvrede met het systeem, kan ook de palliatieve zorg niet buiten het systeem functioneren. Om beschikbaar te kunnen zijn voor mensen die deze zorg nodig hebben, is structurele financiering nodig, en regels en procedures om de zorg te organiseren en voor de toekomst te waarborgen. Besef van de spanning die de rationaliteit, de taal en regels van het systeem waarvan de zorg voor haar voortbestaan noodzakelijkerwijs deel uitmaakt, met zich meebrengt en waardoor de juist zo belangrijk gevonden leefwerelddimensie onder druk komt te staan, is een van de inzichten die geleerd kan worden uit de ontstaansgeschiedenis van de palliatieve zorg. Om de systeemdruk binnen de palliatieve zorg niet te hoog te laten oplopen lijkt het zich bewust zijn van normatieve uitgangspunten en de noodzaak hierop te blijven reflecteren een belangrijke opdracht.

In de gesprekken met zorgverleners over hun motivatie om juist voor de palliatieve zorg te kiezen komt de systeem-leefwereld spanning tot uitdrukking evenals de behoefte daaraan te ontsnappen door voor deze vorm van zorgverlening te kiezen:

Ik heb hier het meest het gevoel dat ik kan doen voor de mensen wat ik ook echt voor ze wil doen. Dat ik zorg kan bieden waar ik ook echt achter sta. En: Ik vind het ideaal om met $z$ 'n allen in ieder geval te proberen om iemand nog juist dat te geven, wat hij eigenlijk zelf nog wil (verpleegkundige, hospice).

Ik ben wel afgeknapt op de 'wijk' van nu, want daar ligt mijn hart nog wel hoor. Alleen niet zoals het nu moet, met een stopwatch langs stervende mensen. Ik kan het niet meer verkopen (verpleegkundige, hospice). 
Het kleinschalige trok me heel erg aan, maar ook de wetenschap dat je hier zorg kunt verlenen op een manier waar mijn hart nog steeds bij lag. De tijdsfactor speelt daar een belangrijk rol in, want dat vind je in de instellingen niet meer (verpleegkundige, hospice).

Besef van drijfveren en normatieve uitgangspunten alleen levert nog niet de ideale praktijk op. Ook dat werd in het onderzoek duidelijk. Zorgverleners staan tussen systeem en leefwereld in. Ze kennen de verhalen van de aan hun zorgen toevertrouwde patiënten, zijn betrokken bij hun wensen en behoeften, tegelijk maken zij deel uit van een organisatie met regels en professionele opvattingen en taalgebruik. Zorgverleners, betrokken bij de leefwereld van patiënten moeten vaak systeemregels volgen. Voorbeelden van hoe die spanning in concrete situaties zichtbaar wordt en druk uitoefent op relationele betrokkenheid, hoe die spanning emoties en vragen oproept, kwamen in het IZO en in de gesprekken met zorgverleners regelmatig aan de orde. Ook de vragen over privacy voor patiënt en familie en het gevoel te kort te schieten, hebben te maken met de spanning tussen systeemeisen en leefwereldverwachtingen. Een van de tragische kanten van de zorgpraktijk is de confrontatie met tegenstrijdige verplichtingen. Een besef dat soms ook het handelen verlamt. Tegenstrijdige verwachtingen en verplichtingen maken duidelijk dat rationele afwegingen en regels niet alle problemen oplossen. Een inzicht dat wordt uitgewerkt door Nussbaum (1986). Zij vat ethiek op vanuit de alledaagse ervaringen en overtuigingen. Niet de abstracte regels zijn uitgangspunt maar relationele betrokkenheid, geen theoretisch engagement maar betrokkenheid op de praktijk, de verhalen, emoties en belevingen van mensen die daarin een rol spelen.

$I k$ vind het wel eens moeilijk als mensen hun intiemste dingen aan mij verteld hebben, hun pijn, hun machteloosheid en schuldgevoel. Hoeveel geef ik daarvan door aan het team? Natuurlijk vind ik dat ik dingen moet rapporteren naar anderen. Maar wat zeg ik wel, wat zeg ik niet? (verpleegkundige, hospice).

Ik herinner mij een jonge vent, die heel veel problemen heeft gehad in zijn leven. Hij kwam uit een orthodox milieu en had dan ook heel veel moeite zijn problemen bij mij neer te leggen. Toen dat vertrouwen er eenmaal was, bleek hij hier niet op zijn plaats en moest hij worden overgeplaatst naar een verpleeghuis. Dat heb ik toen domweg laten gebeuren. Ik heb niet veel tegenwerpingen gemaakt omdat ik dat al een keer daarvoor gedaan had en dat was een beetje geëscaleerd. Dus ik dacht 'dit keer hou ik me er maar een beetje buiten'. Ook om mezelf te beschermen, ik kan niet steeds die confrontaties aan. Daarna is die 
man toch na een maand overleden in het verpleeghuis. Er waren ook nog ouders in het spel. Die ouders zeiden daarna, Wij begrepen niet waarom hij bij jullie weg moest. Ik wist niet wat ik moest zeggen...(verpleegkundige, hospice).

\section{Ethiek}

Twee ethisch theoretische stromingen werden in de voorgaande hoofdstukken voor het voetlicht gebracht. De regelethiek en de zorgethiek. De regelethiek behelst een gestructureerde benadering met duidelijke uitgangspunten. Middels een stappenplan komt men in ethisch moeilijke situaties tot systematische afweging van in geding zijnde principes om vast te stellen hoe te handelen. Het gaat in de regelethiek om principes van weldoen, niet schaden, het recht op autonomie en het principe van rechtvaardigheid. Autonomie wordt opgevat als het recht van de patiënt zelf beslissingen te nemen, de arts heeft de plicht de patiënt zo goed mogelijk te informeren. In de zorgethiek staan relationele betrokkenheid en wederkerigheid meer op de voorgrond. Autonomie wordt niet alleen opgevat als onafhankelijkheid en zelfbepaling, ook kwetsbaarheid en eindigheid maken deel uit van het menselijk bestaan. Mensen zijn in hun autonomie op elkaar betrokken, steun en eventueel ingrijpen van anderen betekent niet automatisch een inbreuk op deze autonomie (Manschot, 1997; Widdershoven, 200ob).

De systeem-leefwereld spanning weerspiegelt zich in de praktijk in een vergelijkbare spanning tussen zorgethiek en regelethiek. Zoals in het voorbeeld van mevrouw Appelman, die voor bestraling naar het ziekenhuis moet. Een behandeling die belastend voor haar is.

Mevrouw Appelman wordt vanuit het hospice regelmatig naar het ziekenhuis gebracht voor bestraling. Verpleegkundigen wijzen er op dat dit te belastend is voor mevrouw, de behandeling leidt niet tot verlichting van de klachten. Zij stel. len de vraag of dit nog wel palliatieve behandeling mag heten.

Zo ook als het gaat om het overplaatsen van patiënten naar een verpleeghuis wanneer de patiënt dat eigenlijk niet wil. Niet alleen voor de patiënt maar ook voor zorgverleners en familie levert dat frustraties op.

Mevrouw Bellenbos is boos over het besluit haar over te plaatsen naar het verpleeghuis. $\mathrm{Ze}$ is sinds zes weken in het hospice en heeft op aanraden van de arts' haar huis verkocht. Heeft nu geen keus meer, geen plek om naar terug te gaan. 
Verpleegkundigen stellen zorgethische vragen en vertolken in een vergelijkbare situatie de stem van de patiënt:

Om zo iemand nog te verplaatsen, nee ik geloof niet dat dat juist is. Dat is een van de grote dilemma's waar we mee zitten en waarvan ik hoor dat het in andere hospices ook zo is, dat mensen daar tegenaan lopen. Zeggen 'de patiēnt hoort hier niet (langer)', is iets waarvan mijn haren overeind gaan staan. En onze ervaring is ook, dat als mensen overgeplaatst worden, zij toch snel komen te overlijden. Ik heb er geen antwoord op...(verpleegkundige, hospice).

Het zijn ervaringen die in het IZO hebben geleid tot kritische reflectie waarin regels tegen het licht werden gehouden van de betekenis ervan in het leven van betrokkenen. Een reflectie die niet tot een oplossing hoeft te leiden voor het probleem, maar wel openheid kan verschaffen over de impact ervan. Zorgvuldigheid en openheid over het hoe en waarom van de regels, begrip voor de implicaties ervan was wat het opleverde.

De ambivalentie van de palliatieve zorgpraktijk kwam in verschillende verhalen van zorgverleners tot uitdrukking. Soms komt het tot een bevredigende oplossing door in het IZO de stem, het verhaal van de patiënt te laten klinken en op te komen voor zijn of haar beleving van de situatie. Zoals bij mevrouw Appelman, waar verpleegkundigen opkomen voor haar kwaliteit van leven in het licht van de behandeling in het ziekenhuis. Het beleid wordt bijgesteld. In andere situaties lukt dat niet, zoals bij het overplaatsen naar het verpleeghuis van mevrouw Bellenbos. Of in geval van de spoedopname die volgens verpleegkundigen bij nader inzien niet zo'n spoedeisend karakter had, maar waardoor wel patiënten moesten verhuizen naar een andere kamer, hetgeen als een storende inbreuk op hun situatie werd ervaren. Ook in de situatie van de heer Altena, de aanleiding voor het proces van beleidsontwikkeling, speelt die ambivalentie een rol. De keuze om beleid te ontwikkelen, een protocol op te stellen, leidde ertoe dat de concrete situatie naar de achtergrond verschoof en het afstandelijk redeneren en het opstellen van regels de nadruk kreeg. Leefwereldvragen werden opgelost door regels en protocollen, passend in het systeem. Dat zal in vergelijkbare situaties in de toekomst opnieuw tot vragen leiden. Vragen die door rationele oplossingen werden weggedrukt omdat regels en protocollen meestal geen antwoord geven op existentiele vragen en emoties die in concrete situaties vaak een belangrijke rol spelen.

Ondanks de beperkingen van het IZO wat betreft de beschikbare tijd en het niet altijd aanwezig zijn van de verschillende disciplines, biedt dit forum zorgverleners wel de mogelijkheid spontaan concrete ervaringen in te brengen en te reflecteren op normatieve uitgangspunten en leefwereldvragen. Meer dan in 
het proces van beleidsontwikkeling blijft hier de oriëntatie gericht op wat goed is in concrete situaties die zich steeds weer en steeds anders voordoen. Het praktijkonderzoek maakte duidelijk dat waar principes vastliggen, minder behoefte lijkt te zijn voor kritische reflectie. Met door de arts ingebrachte voorstellen om in situaties van steeds terugkerende infectie af te zien van behandeling, maar enkel pijn- of symptoombestrijding aan te bieden, na over de voors en tegens met de patiënt te hebben gesproken, werd steeds zonder al te veel discussie ingestemd.

De zorgethiek noch de regelethiek lijken ieder voor zich voldoende bij te dragen om de spanning tussen leefwereld en systeem te overbruggen en de palliatieve zorg daarmee een fundament te verschaffen om haar eigenheid te bewa. ren. De regelethiek biedt houvast in de dagelijkse praktijk en schept kaders voor een methodisch omgaan met ethische problemen. De kwetsbare kant van de regelethiek is dat zij door het terugbrengen van ethische problemen tot principes en protocollen, het gevaar in zich draagt dat andere belangrijke elementen die in concrete situaties een rol spelen, buiten spel blijven. Het is een rationele benadering die aansluit bij de systeemwereld. De zorgethiek is meer dan de regelethiek gericht op de praktijk en de persoonlijke beleving van mensen om wie het gaat. De patiënt is partner in het gesprek over wat wel of juist niet bijdraagt aan zijn of haar welbevinden. De praktijkgerichtheid biedt mogelijkheden voor de 'veelstemmigheid' van dat overleg. De kwetsbaarheid van de zorgethiek is dat door de nadruk op relationele betrokkenheid en leefwereldervaringen het gevaar van isolement dreigt, leefwereld en systeem verder van elkaar verwijderd raken.

Ethiek als bron voor het denken en handelen, staat regelmatig onder druk van rationele regelsystemen, maar lijkt juist ook door de emoties en existentiële vragen die deze spanning voor betrokkenen met zich meebrengen, een drijvende kracht. Zo zouden zorgethiek en regelethiek een aanvulling kunnen zijn op elkaar of een wisselwerking teweegbrengen. De regelethiek geeft duidelijkheid, houvast in moeilijke en acute situaties, zorgethiek blijft dicht bij de beleving, de betekenis van de concrete situatie in het leven van betrokkenen en zoekt naar oplossingen voor de spanning en frustratie van een al te 'geregeld' beleid. Een werking die echter alleen mogelijk is in een klimaat waar normatieve uitgangspunten een blijvende en heldere bron zijn voor het handelen én voor reflectie op zowel uitgangspunten als op de werking ervan in de praktijk. Waar zorgverleners en management kunnen putten uit eigen existentiële bronnen en van daaruit verbanden kunnen leggen met het werk dat ze doen en de wijdere maatschappelijke context. Hoewel het onderzoek te beperkt is om algemene conclusies te trekken, is er alle reden om aan te nemen dat dit de factoren zijn die een 
belangrijke rol spelen om de palliatieve zorg haar eigenheid te laten behouden, ook als ze straks weer integraal deel uitmaakt van het gezondheidszorgsysteem.

\section{Communicatie}

De spanning tussen leefwereldervarigen en behoeften en systeemeisen zet het herkennen van en het spreken over morele- en existentiële ervaringen onder druk. Voor de praktijk van palliatieve zorgverlening zijn communicatie en ethiek belangrijk. Ethiek in praktijk vraagt om ruimte voor het organiseren van structurele vormen van communicatie en reflectie. Verkerk wijst op de sociale context waarbinnen de zorgverlening zich afspeelt en ethische vragen en problemen zich voordoen. $\mathrm{Zij}$ zegt: 'morele kwesties komen niet uit de lucht vallen maar zijn altijd van iemand die op zijn of haar beurt een bepaalde plek inneemt in de sociale werkelijkheid, die vaak door machtsverhoudingen is gekleurd' (Verkerk, 2000, p. II5). Zij wijst niet alleen op de inbedding van ethiek in de praktijk maar ook op de verschillende perspectieven waarmee mensen naar die praktijk en naar ethische kwesties in die praktijk kijken. Morele opvattingen zijn verbonden met de identiteit van mensen en daardoor vaak emotioneel geladen, aldus Verkerk. Dit staat op gespannen voet met de rationaliteit van het systeem. Morele kwesties verdragen zich niet goed met associaties van afstandelijkheid en maakbaarheid, die daaraan eigen zijn. Deze spanning maakt het soms moeilijk. Ze beperkt de ruimte voor communicatieve uitwisseling en het stellen van vragen op het gebied van zingeving en moraliteit. Maar het maakt deze vragen daarmee niet onzegbaar. Kunneman (I999) gebruikt de term trage vragen voor problemen die zich aan de logica van moderne technologische ontwikkelingen onttrekken, en die als zingevingsvragen worden aangeduid.

Een van de mogelijkheden in het hospice voor regelmatig overleg over ethische problemen is het IZO. In het IZO is ruimte voor de beleving, de emoties en vragen die in concrete ervaringen een rol spelen. Meer dan in de bijeenkomsten over sedatiebeleid het geval was. Daar verdween de concrete ervaring die aanleiding was voor het overleg naar de achtergrond. Een moreel beraad vraagt dan ook niet alleen een communicatief klimaat waarin de verschillende perspectieven ruimte krijgen voor reflectie en overleg in het zoeken naar wat juist en goed is in moeilijke situaties. Net zo belangrijk is het dat die situaties in de discussie centraal blijven staan. Juist in de concrete ervaringen komt de kwetsbaarheid van individuen (zorgverleners én patiënten) aan het licht en krijgt de spanning tussen systeem en leefwereld woorden in vragen die daaruit opklinken. Trage vragen zoals Kunneman (1999) ze noemt, die steeds weer opborrelen en oproe- 
pen tot reflectie. De mogelijkheid die het IZO biedt spontaan ethische vragen of ervaringen in te brengen, komt hieraan tegemoet. Hierdoor ontstaat ruimte voor emoties en kwetsbaarheid, ruimte om zich in te leven in het verhaal dat verteld wordt over concrete ervaringen en het effect daarvan op mensen.

\section{De responsieve methode}

In de responsieve onderzoeksbenadering neemt de hermeneutische dialectiek een belangrijke plaats in. Belanghebbenden in de praktijk worden zoveel mogelijk bij het onderzoek betrokken door met hen in gesprek te gaan over de onderwerpen en vragen. Zowel die bij de onderzoeker leven, als die welke zich in de praktijk voordoen. Een strak ontwerp zoals in kwantitatief onderzoek is dan ook niet geëigend. Er moet ruimte zijn voor de vragen, verwachtingen en waarden die in de praktijk een rol spelen en daar om aandacht vragen (Abma en Widdershoven, 2002). In een gezamenlijk proces worden spanningen in de praktijk inzichtelijk gemaakt en problemen en mogelijke oplossingen verhelderd. De rol van de onderzoeker is niet die van een afstandelijke deskundige, maar van iemand die betrokken is bij die praktijk, er deel van uitmaakt, beschikt over interpreterend vermogen en in staat is bij te dragen aan een klimaat waarin door samenspraak leerprocessen in gang worden gezet en wenselijk geachte veranderingsprocessen mogelijk worden.

Zo ook ontvouwde zich tijdens het onderzoek een proces, dat weliswaar door de onderzoeker in gang was gezet, maar dat werd bijgestuurd door de belanghebbende zorgverleners. In plaats van de door de onderzoeker geinitieerde groepsbijeenkomsten over kwesties die in de interviews een rol speelden, werd gekozen voor een proces van beleidsontwikkeling. Dat vond plaats in een multidisciplinaire samenspraak in verscheidene bijeenkomsten, aan de hand van een voor betrokkenen moeilijke praktijksituatie.

Een aanpak, die verrassingen oplevert omdat niet van te voren kan worden vastgesteld wat het belangrijkste probleem is waar het onderzoek licht op zal werpen. Bij ethiek en palliatieve zorg denken veel mensen direct aan vragen rond euthanasie, stoppen van medicatie en abstinerend beleid. In de gesprekken met zorgverleners bleken ook andere ethische kwesties vragen op te leveren. Zoals het in het oog springende voorbeeld van de situatie van het 'verkeerde bed'. Maar ook vragen over de privacy van de patiënt, de vraag in hoeverre ingezet beleid toevoegt aan de kwaliteit van leven (het palliatieve van een behandeling). Vragen die te maken hebben met verschillen van inzicht tussen zorgverleners en familie en vragen die te maken hebben met onmachtsgevoelens van zorgverleners. 
De stem van patiënt(en) en familie is in het onderzoek onderbelicht gebleven. Slechts één patiënt en één familielid werd geinnterviewd. Ook maakten zij geen deel uit van het forum voor beleidsontwikkeling. De stem van de patiënt en zijn naasten werd in het onderzoek vooral door verpleegkundigen in het overleg ingebracht. De periode waarin ik als vrijwilliger meewerkte in de praktijk, verschafte mij wel een beeld van de situatie van patiënten en familie. In het bijzonder hun kwetsbaarheid weerhield mij ervan hen op grotere schaal rechtstreeks in interviews te benaderen. In een eventueel vervolg zou hier, rekening houdend met die kwetsbaarheid, meer aandacht aan kunnen worden besteed. Waardoor ook hun vragen, verwachtingen en waarden een gelijkwaardiger inbreng krijgen en kunnen bijdragen tot meer inzicht en begrip.

De gevolgde onderzoeksbenadering leverde voldoende mogelijkheden om met de praktijk in gesprek te gaan. Zij biedt echter weinig duidelijkheid over de implementatie van de leerprocessen die plaatsvonden. Wat dat betreft is dezelfde spanning waarneembaar als tussen systeem en leefwereld. In de responsieve methode speelt de leefwerelddimensie, de praktijk en de ervaringen van mensen die daarin bij elkaar betrokken zijn, een belangrijke rol. Daarom ook sloot deze aanpak goed aan bij de palliatieve zorg, waar het niet alleen gaat om het beheersen van fysieke problemen, maar waar de beleving, de leefwereld van de patiënt, ook de aandacht heeft. Synergie is er ook met de zorgethiek. Zo viel het in het IZO op dat verpleegkundigen vaak zorgethische vragen stelden en de leefwereldaspecten van de patiënt inbrachten. In alle drie, de responsieve methode, palliatieve zorg en zorgethiek, staat de leefwereld en relationele betrokkenheid centraal.

Waar de samenspraak regels en protocollen oplevert, zoals in de bijeenkomsten over de situatie van de heer Altena die uitmondden in sedatiebeleid, wordt de responsiviteit beperkt doordat afstand wordt genomen van de concrete situatie die de inzet was van het overleg. Het tragische aspect van de keuze wordt versluierd door een rationele afweging aan de hand van een protocol.

Het onderzoek maakt de ambivalentie van de praktijk inzichtelijk. De nadruk op de belevingsaspecten in de palliatieve zorg en een louter zorgethische benadering, creëert kwetsbaarheid en isolement. Regels en protocollen beperken kritische reflectie en communicatie. Om de spanning van die tweeslachtigheid leefbaar te houden en kwaliteit van zorg te kunnen blijven bieden, is het noodzakelijk om aan de hand van de verhalen van mensen, de concrete situaties die zich voordoen, blijvend bewust te zijn van de normatieve uitgangspunten van de palliatieve zorg en daarop te reflecteren.

Ik hoop dat dit boek, door de vragen en de gesprekken die het oplevert, daaraan een bijdrage mag leveren. 


\section{Care on the border, an ethical perspective on Palliative Care}

\section{SUMMARY}

When he could no longer bear the silence in his room, he would press the alarm button next to his chair. His hearing, like his eyesight, had deteriorated lately. He didn't hear the 'yes, please?' which sounded through the intercom. Again he rang, again ... 'We're on our way!'. The sound reached his ear: they heard him...

He immediately started to talk: a glass of water, he wanted, chilled please. And who was he talking to, he also asked. The intercom remained silent. It was already disconnected. When the nurse came into his room after an hour, he couldn't remember. Why had he rung?

The first paragraph tells the story about the last stages of the life of a dear friend: a period that confronted me with experiences in which physical dependency and the need for care met walls of incomprehension and rancour. Situations in which the path to self-reflection appeared to be blocked, so that the patient, but also the care-giver, found themselves in isolation, a situation that stood in contrast with the philosophy of the palliative care movement, which by that time was developing in the Netherlands and with which I was closely involved. In retrospect, it was that concrete situation which was my motivation, the start of a quest for the practice of palliative care and the place of ethics therein.

This study offers a multidisciplinary sketch of palliative care and ethics from the perspectives of care-givers, patients and family. The research took place at the hospice Rozenheuvel in Rozendaal. Theoretical perspectives have been employed to analyse the practice of care-giving and to clarify the concrete situations which arise. The tension between the system and real-life experiences along with the urgency of making moral values recognisable and topics for ongoing discussion are illustrated by actual cases. The approaches of careethics and rule-ethics are placed in the context of this ongoing tension between the real-life experiences and expectations and system rules. 
The purpose of this research is to make a contribution to the practice and theory of palliative care through the description and clarification of ethical problems as they arise in the actual practice of care-giving and to search for guidelines for the people involved. The goal was to locate forms of communication and ethical reflection, which could guarantee the continuance and further development of the unique qualities of palliative care.

The summary presents the findings of the research and its methodology. In doing this, it focuses on how the theoretical perspectives - social theory, ethics, and communication as a precondition for ethics - have contributed to the understanding of the practice of care-giving and to the clarification of the tensions confronting the care-givers. The responsive method offers possibilities for an optimal dialogue with all the people involved in the practice, not just with the care-givers, but also the patients and their families.

\section{Theoretical framework System and real-life situations}

The development of science and technology in modern times, coupled with specialisation in knowledge and practice, has led to sub-systems with their own languages and rationales to which the self-evident everyday world has no access. Important and far-reaching life experiences with which people are confronted, such as handicaps, illness and death, disappear from sight in the development of specialised facilities with their own knowledge base, rules and assumptions in order to maintain and develop these facilities. The sharing and exchange of experiences and feelings concerning what it means to be confronted with obstacles to existence are less self-evident and existential meaning is institutionalised. People learn to express these in the language of the caregivers. Solutions are sought in technical possibilities and facilities.

Furthermore, the secularisation and removal of religious references, resulting from the individualisation and rationalisation of modern times, make collective answers to existential and emotional occurrences less extensive or less accessible. While these developments have made a contribution to emancipation and freedom from hierarchical forms of suppression and power, they have also created a vacuum of powerlessness and lack of communal frameworks for reflection in the dimensions of life experience. 
The development of palliative care in the Netherlands, but also worldwide, can best be explained as a contra-movement, initiated by people in the healthcare sector or in humanistic or religious organisations who were no longer willing to accept the approach to the care of terminal patients as practiced in hospitals. While the hospital focuses on treatment and cure, palliative care considers care itself and the quality of life as paramount. This type of care is not only directed to physical aspects but encompasses 'total care': emotions, existential questions and social aspects receive equal attention. Such care is offered and developed in small care facilities, such as hospices and 'almost at home' houses.

While palliative care arose from discontent with the limitations of the healthcare system, it cannot function outside that system. Structural financial support is necessary in order for it to be accessible to people who need this care. Rules and procedures are equally crucial for the organisation of palliative care and the guarantee of its continuance. A realisation of the tension which accompanies rationality and how this places pressure on important dimensions of daily life is one of the insights to be gained from the historical development of palliative care. In order to prevent the pressure exerted by the system from reaching excessively high levels, an awareness of the fundamental norms and values and of the necessity for continuous reflection appear to be important tasks.

Knowledge of the motivation and the norms and values of palliative care alone do not result in the ideal practice. This research also corroborates that point. Care-givers are caught in the middle between the system and the real world. They know the case histories of their patients and are involved in their wishes and needs. Simultaneously they belong to an organisation with its own rules, professional assumptions and language. Care-givers, sharing daily life experiences with their patients, often have to follow system rules. Examples of how this tension in real situations becomes apparent and clouds relational concerns were presented regularly in the weekly Internal Care Council (IZO) and in conversations with the care-givers themselves.

One of the tragic aspects of a care-giving practice is the confrontation with conflicting obligations. Conflicting expectations and duties clearly illustrate that rational considerations and rules do not solve all problems. Nussbaum provides further insight, using her concept of an ethics based on everyday experience, convictions, and relational involvement. Neither abstract rules nor theoretical engagement lead to relational involvement in the practice of care-giving. 
This is reached through openness to the case histories, emotions and experiences of people involved.

\section{Rule-ethics and care-ethics}

The study focuses on two approaches in ethics: rule-ethics and care-ethics. Ruleethics comprises a structural approach with clearly defined points of departure. A phased plan assists care-givers step by step to make decisions regarding the principles and treatments valid in ethically difficult situations. Rule-ethics is concerned with the principles of well-doing and avoiding damage, the right to autonomy and the principle of justice. Autonomy is defined as the right of the patient to make their own decisions. The doctor has an obligation to inform the patient as completely as possible.

In care-ethics, relational involvement and reciprocity are more central. Autonomy is not just perceived as independence and self-determination. Vulnerability and finiteness are also viewed as part of human existence. People are involved with each other in the exercise of their autonomy. Support and the eventual actions of others do not automatically constitute an intrusion into this autonomy. The tension between the system and real-life experience is mirrored in the care-giving practice and there is a comparable tension between the ethics of care and the ethics of rules. This is illustrated in myriad examples throughout the study.

Neither care-ethics nor rule-ethics appears to be sufficient by itself to bridge the tension between the everyday world and the system in order to provide a foundation to protect the unique qualities of palliative care. Ethics as a source for thought and action is directly under pressure from the rational rules system. At the same time, however, it serves as a driving force for the emotions and existential questions, which this tension creates for those concerned. In that sense, care-ethics and rule-ethics can be seen as complementary to each other or as vehicles for exchange. Rule-ethics offers clarity and structure in difficult and crisis situations, while care-ethics remains close to experience itself and seeks solutions for the tension and frustration of a too rigorous policy. Such cooperation is only possible in a climate where normative points of departure provide a continuous and clear source for treatment and reflection on both assumptions and their effect on the practice itself. Even though this research is too limited to draw general conclusions, it nevertheless pinpoints factors that play an important role in guaranteeing that palliative care main- 
tains its uniqueness, even when it becomes integrated into the regular healthcare system.

\section{Communication as condition for the practice of care-giving}

The conflict between the experiences of daily life and the demands of the system limits the discussion of moral and existential experiences. Communication is essential for the practice of palliative care. Ethics in a caregiving practice requires space for the organisation of communication and reflection. According to Verkerk, the social context is important, as moral questions do not arise of themselves. People in a given social reality, often coloured by power relationships, pose these ethical questions from their own diverse perspectives. Moral beliefs are closely allied with the identity of people and consequently the resulting actions are frequently emotionally charged. This represents a strong contradiction to the rationality of the system. Moral questions do not mesh well with the concepts of objectivity and feasibility, which are inherent in the system. The tension sometimes makes it so difficult that it limits the space for communication and the posing of existential and moral questions. This does not mean, however, that the question cannot be raised. Kunneman employs the term 'slowly arising' or 'delayed questions', to describe problems, classified as existential matters, which lie outside the logic of modern technological development but which will eventually surface and call for reflection.

The hospice Internal Caregiving Council (IZO) offers one possibility for regular discussion of ethical questions. Such a council provides space for life experience and the emotions and questions that play a role in real-life situations. Policy meetings, on the other hand, address more procedural issues such as general treatment and sedation policy. The real-life situation, which was the original cause for the meeting, disappears into the background. A moral decision-making board requires not only a communication climate wherein diverse perspectives receive space for reflection and negotiation in the search for what is right and good in difficult situations but, equally important, ensures that those situations remain central to the discussion. The climate is enhanced by the presence of diverse points of view. Therefore, it is important that the complete multidisciplinary team be present. The opportunity offered by the IZO for ethical questions and experiences to be spontaneously brought into the discussion meets that need. Space is created for emotions and vulnerability, space for empathy with the real-life story and experience being related, and its 
effects on the individuals concerned.

\section{A responsive methodology: furthering dialogue between participants}

The hermeneutic dialogue, whereby people interpret their existence through interaction with each other, has an important role in this approach. A broad dialogue was initiated with care-givers and personnel as far as scheduling permitted. Discussions addressed both the researcher's and care-givers' questions. A rigid structure as in quantitative research was not sought. There needed to be space for the questions, expectations, and norms and values that play a role in the practice. Researcher and practitioners set up a joint process to uncover tensions in the practice and clarify the problems present.

Research activities undertaken included: participatory observation, preparatory discussions with the management, introductory meetings to clarify the purpose and methodology of the study, and the use of case studies of care-giving practice to initiate a dialogue with those working in the hospice. Interviews were held not only with doctors and nurses who participated in the different situations but also with pastoral and social workers and others involved with the hospice work. The weekly care-giving council (IZO) was attended to monitor the decision-making on ethical questions posed by the care-givers. Multidisciplinary meetings were organised to discuss relevant issues which arose in the interviews, e.g. expectations about good care, ethics and autonomy.

In the responsive method, the researcher is not an independent expert but rather a participant involved in the process along with other participants. The researcher's contribution is the capacity to interpret and to create a climate wherein a learning process through dialogue is initiated, and desirable change processes are possible. In this study, a process unfolded which, after being set in motion by the researcher, was adopted and worked out further by the caregivers themselves. Instead of group meetings on topics chosen by the researcher from the interviews, a choice was made to initiate a process of policy development on sedation.

This approach delivered a number of surprises, as the most pressing problem for study in the council could not be predetermined. Generally, people associate ethics and palliative care directly with issues such as euthanasia, discontinuation of medicine and abstinence policy. The conversations with the care-givers brought other issues to the forefront. These included: the transfer of patients 
to other types of facilities against their will, patient privacy, the effects of the current care policy on the quality of life (the palliative aspect of the care) and issues concerning the knowledge of care-givers and family and the care-givers' own feelings of powerlessness.

The voices of the patient and family were not sufficiently audible in this study. Only one patient and one relative were interviewed, and they did not participate in the policy forum. The views and wishes of the patient and their family were primarily expressed in the council discussion by the nurses. The researcher gained additional understanding of the situation of the patient and their family during a twelve-month period as a volunteer in the study. The realisation of the patient's vulnerability inhibited the researcher from large-scale interviewing. This is however an area that warrants more attention. The patients' questions, expectations and norms and values would result in a more balanced overall picture for consideration and could contribute to better insight and understanding.

The research methodology followed resulted in sufficient opportunities for dialogue with hospice practitioners. It was, however, not sufficient for an evaluation of the implementation of the learning process that took place or of its future viability. The same tension was noticeable between the system and daily life experience. In the responsive method the dimension of daily life, the (hospice) practice and the experiences of the people involved with each other are key. For that reason the responsive method is especially suitable for palliative care, which focuses on the daily life and experience of the patient rather than only on the treatment of physical problems. This synergy also extends to the ethics of care. That explains why it was the nurses who frequently brought up ethical questions of that nature along with specific aspects of the patient's life experience. The responsive method, palliative care and the ethics of care all consider daily life and relational involvement as their central focus.

The research has made the ambivalence of the current hospice practice evident. Emphasis on aspects of experience in palliative care in a care-ethics approach alone creates vulnerability and isolation. Rules and protocols in ruleethics limit critical reflection and communication. In order to make the tension between these two bearable and to be able to continue to offer the quality of care, it is necessary to remain aware of the life histories of people and the real-life situations in which they occur while continuing to reflect on the normative assumptions of palliative care. The research noted a tendency towards dominance of rule-ethics. This study with all its questions and clarifications 
should be seen as a small contribution to the dialogue needed to assist caregivers, patients and families and all those involved with palliative care practices in their own process of discovery and learning.

Doorn, May 2003 
Glinsterende zon een druppel dauw een dorstig blad. Een diamant verbleekt in het licht van deze schat.

Schitterend, glanzend rond,

volmaakt moment dat ik

het vond.

Een leven lang

op zoek naar

iets van waarde,

ligt zomaar

op de grond,

de aarde. 



\section{Literatuur}

Abbeele, C. vanden (200I) De kunst van het afscheid nemen, beelden van innerlijkheid. Tielt: Lannoo

Abma, T.A. (1996) Responsief evalueren. Discoursen, controversen en allianties in het postmoderne. Delft: Eburon.

Abma, T.A. (2000) Spanningsvolle samenwerkingsrelaties tussen professionals en naasten. Verpleegkunde, 15, (4), 201-213.

Abma, T.A. (2001) Evaluating palliative care: Facilitating reflexive dialogues about an ambiguous concept, Medicine, Health Care and Philosophy, (4). $26 \mathrm{I}-276$.

Abma, T.A. \& R.E. Stake (2001) Stake's Responsive Evaluation: Core Ideas and Evolution. New directions for Evaluation, (92), 7-21.

Abma, T.A. (2002) Emerging Narrative Forms of Knowledge Representation in Health Sciences: Two Texts in a Post-modern Context, Qualitative Health Research, 12, (I), 5-27.

Abma, T. \& G. Widdershoven (2002) Responsieve evaluatie en haar betekenis voor de verplegingswetenschap, Verpleegkunde, 17, 207-220.

Asperen, G.M. van (1993) Het bedachte leven. Beschouwingen over maatschappij, zingeving en ethiek. Amsterdam/Meppel: Boom.

Baar, F. (2000) Jaarlijkse Landelijke Netwerkdag NPTN, Ede.

Beauchamp, T.L. \& J.F. Childress (1994) Principles of biomedical ethics. Oxford: Oxford University Press.

Begeman, F.A. (1995) Hulp aan slachtoffers van de Tweede Wereldoorlog; Een Visic. Lisse: Swets \& Zeitlinger.

Belderok, J. (1997) Moderniseringstheorieën van Habermas en Giddens, toegepast op het verzorgingshuis en het somatisch verpleeghuis. Tijdschrift voor Gerontologie en Geriatrie, 28: 247-253.

Boot J.M. \& M.H.J.M. Knapen (200I) Handboek Nederlandse gezondheidszorg. Utrecht: Het Spectrum.

Borst-Eilers, E. (1999), Vaststelling van de begroting van de uitgaven en de ontvangsten van het Ministerie van Volksgezondheid, Welzijn en Sport (XVI) 
voor het jaar 1999, brief van de Minister van Volksgezondheid, Welzijn en Sport, 's Gravenhage, 3 mei.

Borst-Eilers, E. (2000) Brief aan de Voorzitter van de Vaste Commissie voor Volksgezondheid, Welzijn en Sport van de Tweede Kamer der StatenGeneraal, 's Gravenhage, I4 april.

Borst-Eilers, E. (2000) Brief aan de Voorzitter van de Vaste Commissie voor Volksgezondheid, Welzijn en Sport van de Tweede Kamer der StatenGeneraal, 's Gravenhage, 13 oktober.

Broeckaert, B. \& J.M. Núnez Olarte (2002) Sedation in palliative care. Facts and concepts. In: Ten Have H.A.M.J., D. Clark, red., The Ethics of Palliative Care. European Perspectives. Buckingham: Open University Press.

Bruntink, R. (2001/2002), Palliatieve sedatie. Pallium, 3, (6), 7-II.

Clark, D. (ed.) (1993) The Future For Palliative Care. Buckingham: Open University Press.

CVZ, College voor Zorgverzekeringen (200I) Brief aan Zorgkantoren betreffende Toepassing ITZ-regeling in hospices en bijna-thuis-huizen, Amstelveen, 25 januari.

Dartel, H. van, M. Jacobs \& R. Jeurissen (200I) Sociale en ethische verantwoording in de Gezondheidszorg. Nijenrode en CElAZ in opdracht van het Ministerie van VWS.

Dekkers, W. (2002) Terminale sedatie of euthanasie? Tijdschrift voor geneeskunde en ethiek, 12, (3). 73.

Dondeyne, M. (2002) In: R. Bruntink, Palliatieve Sedatie. Pallium, 3, (6) 8.

Doyle, D., G.W.C. Hanks \& N. Mc Donald (1993) Oxford Textbook of Palliative Medicine. Oxford: Oxford University Press.

Dupuis, H.M. (1998) Op het scherp van de snede; goed en kwaad in de geneeskunde, Amsterdam: Balans.

Enklaar, J. (1999) Terminus. Dr. Ben Zylicz en de kunst van het sterven. Zutphen/Apeldoorn: Plataan.

Faulkner, A. \& P. Maguire (1994) Talking to Cancer Patients and Their Relatives. Oxford: Chapman \& Hall.

Francke, A.L. (2003) Palliative Care for Terminally ill Patients in the Netherlands, Dutch Government Policy, Ministry of Health, Welfare and Sport in the Netherlands, March.

Gadamer, H.G. (1986) Wahrheit und Methode, Grundzüge einer philosophisen Hermeneutik. Tübingen: J.C.B. Mohr.

Giddens, A. (200I) Modernity and Self-Identity, Self and Society in the Late Modern Age. Cambridge: Polity Press.

Gilligan, C. (1982) In a Different Voice; Psychological Theory and Women's Development. Cambridge: Harvard University press. 
Graste, J. \& D. Bauduin (red) (2000) Waardevol werk, ethiek in de geestelijke gezondheidszorg. Assen: Van Gorcum.

Guba, E.G. \& Y. Lincoln (1989) Fourth Generation Evaluation. Beverly Hills: Sage.

Habermas, J. (1981) Theorie des kommunikativen Handelns, Band 1 , Handlungrationalität und Gesellschafiliche Rationalisierung. Frankfurt am Main: Suhrkamp Verlag.

Hammersley, M. \& P. Atkinson (1995) Ethnoghraphy, Principles in Practice. New York/London: Routledge.

Hattinga Verschure, J.C.M. (200I) Voorwoord in: J.M. Boot en M.H.J.M. Knapen. Handboek Nederlandse gezondheidszorg. Utrecht: Het Spectrum.

Have, H.A.M.J. ten, R.H.J. ter Meulen \& E. van Leeuwen (1998) Medische ethiek. Houten/Diegem: Bohn Stafleu Van Loghum.

Janssens, R.J.P.A. e.a. (2002) Controversen rondom terminale sedatie, Tijdschrift voor Geneeskunde en Ethiek, 12, (3), 79-83.

Janssens, R. (I999) Blik op de geschiedenis van de hospice-zorg: 'Palliatieve zorg is in eerste instantie een filosofie'. Pallium, 1, (I), 24-27

Janssens, R. (200I) Palliative care, Concepts and ethics. (proefschrift), Nijmegen

Jonker, J. (2000) Sedating in the hospice, An audit on sedating and communication with patients and family in a Hospice for terminally ill patients. (Audit performed as a part of the "Diplome in Palliative Medicine Course I999-2000"), Wales, Uchgelen.

Keirse, E. (I996) Psychologische aspecten van palliatieve zorg. In: Orshoven, A. van en J. Menten (red), Palliatieve zorg, stervensbegeleiding, rouwbegeleiding. Leuven, Amersfoort: Acco, 183-210.

Korthals, M. (1983) Filosofie en intersubjectiviteit, een kritische inleiding in de systematische filosofie. Alphen aan de Rijn/Brussel.

Kunneman, H. (1986) De waarheidstrechter, een communicatietheoretisch perspectief op wetenschap en samenleving. Amsterdam/Meppel: Boom.

Kunneman, H. (1996) Van theemutscultuur naar walkman-ego, Contouren van postmoderne individualiteit. Amsterdam/Meppel: Boom.

Kunneman, H. (1998) Postmoderne moraliteit. Amsterdam/Meppel: Boom.

Kunneman, H. (1999) Levenskunst en burgerschap in de technopolis, Socrateslezing van Harry Kunneman. Utrecht: Universiteit voor Humanistiek.

Kübler-Ross, E. (I970) Lessen voor levenden; gesprekken met stervenden. Bilthoven: Ambo.

Maas, P.J. van der, J.J.M. van Delden \& J. Pijnenborg (1991) Medische beslissingen rond het levenseinde. 's Gravenhage: Sdu Uitgeverij. 
Manschot, H. \& M. Verkerk (red.) (I997) Ethiek van de Zorg, een discussie. Amsterdam/Meppel: Boom.

Manschot, H. (1997) Kwetsbare autonomie: Over afhankelijkheid en onafhankelijkheid in de ethiek van de zorg. In: H. Manschot \& M. Verkerk (red.) Ethiek van de Zorg, een discussie. Amsterdam/Meppel: Boom.

McClelland, M. \& R. Sands (1993) The Missing Voice in Interdisciplinary Communication. Qualitative health research, 3, (I), 74-90.

Ministerie van VWS (2000) Memorie van Toelichting, begroting 2001, 's Gravenhage, september.

Ministerie van VWS (200I) De zorg voor het levenseinde in Nederland, 's Gravenhage, II april.

Moen, J. \& T.A. Abma, Het ziekenhuis als een transactienetwerk van maatschappen, In: P. Jong, de, A.F.A. Korsten \& J.H. van der Made. Ziekenhuizen: besluitvorming en management. Assen: Van Gorcum, 18-27.

Moody, H.R. (1992) Ethics in an aging society. New York: The Johns Hopkins University Press.

Nuij, M. \& A. Hoogerwerf (2000) Over de grens tussen normaal en buitengewoon medisch handelen. Tijdschrift voor Geneeskunde en Ethiek, 10, (4), 121-125.

Nussbaum, M.C. (1986) The fragility of goodness. Luck and ethics in Greek tragedy and philisophy. Cambridge: Cambridge University Press.

Nussbaum, M.C. (1998) Wat liefde weet, Emoties en moreel oordelen. Amsterdam/Meppel: Boom.

NPTN, Netwerk Palliatieve Zorg voor Terminale Patiënten Nederland (1996)

Beleidsplan, Bunnik.

NPTN, Netwerk Palliatieve Zorg voor Terminale Patiënten Nederland (200I), Lijst van gespecialiseerde Palliatieve Zorgvoorzieningen. Bunnik, mei.

Nijs, E. de (2000) Palliatieve zorg. In: Osselen-Riem, A.van, B. van Dijk \& E. de Nijs (red.). Theorie en praktijk van de palliatieve zorgverlening. Utrecht: Lemma.

Orshoven, A. van \& J. Menten (red) (1996) Palliatieve zorg, stervensbegeleiding, rouwbegeleiding. Leuven/Amersfoort: Acco.

Osselen, A. van ( 1989 ) Hoe hermeneutisch is het genetisch structuralisme? Kritiek op de identificatie en verticale reconstructie van oordeelsstructuren in genetisch structuralistische stadiumtheorieën, naar aanleiding van de controverse tussen Kohlberg en Gilligan. (doctoraalscriptie), Nijmegen.

Osselen, A. van (1993) Omgaan met de dood. Streven, (8), 753-757.

Osselen, A. van (1994) Woordenwolken in mijn hoofd. Rotterdam: Ydé pr \& publiciteit. 
Osselen, A. van (red.) (1997) Hulpverlenen doe je samen, Landelijk Steunpunt Vrijwilligers Terminale Zorg, Bunnik, Stichting IVIO, Lelystad.

Osselen, A. van \& A. Vigelius (1999) Verbeelding, werk in steen en op papier. Poëzie van Jeanette van Osselen en beelden van Anneke Vigelius, Utrecht: Tulip.

Osselen, A. van, B. van Dijk \& E. de Nijs (red.) (2000) Theorie en praktijk van de palliatieve zorgverlening. Utrecht: Lemma.

Pijnenburg, M., J. Mulder \& H. Schellekens (2002) Waarden in de zorg, waarden voor de politiek. Tijdschrift voor Geneeskunde en ethiek, 12, (I), I.

Poppema, M. en C. Ziedses (1998) Deskundigheid en autonomie. (scriptie) Christelijke Hogeschool Ede.

Prins, M. (1999) Spirituele zorg. In: Pool, A. en J. Lambregts (red.) Verpleegkundige zorgverlening aan chronisch zieken. Utrecht: Lemma.

Projectgroep Integratie Hospicezorg (1999) Concept nota Hospice voorzieningen geintegreerd binnen een samenhangend geheel van palliatieve terminale zorg. Voorburg, december.

Projectgroep Integratie Hospicezorg (1999) Hospice voorzieningen geīntegreerd binnen een samenhangend geheel van palliatieve terminale zorg. Voorburg, december.

Projectgroep Integratie Hospicezorg (2001a) Bekostiging van de zorg voor terminale patiënten. Voorburg, juni.

Projectgroep Integratie Hospicezorg (200rb) Naar een betere, meer samenhangende zorg voor mensen, die terminaal zijn. Voorburg, juni.

Projectgroep Integratie Hospicezorg (2001) Verbetering van de zorg voor mensen in de terminale fase en hun naasten. Voorburg.

Werkgroep bekostiging van de projectgroep integratie hospicezorg (200I) Bekostiging van de zorg voor terminale patiënten. Juni.

RIVM, Rijksinstituut voor Volksgezondheid en Milieuhygiëne (1993) Volksgezondheid Toekomstverkenning. Den Haag.

RvZ, Raad voor de Volksgezondheid \& Zorg (2000) Kabinetsstandpunt Ethiek met beleid. Zoetermeer.

Saunders C. (1990) Hospice and Palliative Care, an Interdisciplinary Approach. London: Edward Arnold.

Saunders C. \& N. Sykes (1993) The Management of Terminal Malignant Disease. London: Edward Arnold

Scholberg, T. (1995) Development in Palliative Care in Norway: an overview. International Journal of Palliative Nursing, 1, (I)

Schotmans, P. (2000) Gecontroleerde sedatie bij de terminale patiënt met refractaire symptomen in het aanschijn van de dood. Een ethische verant- 
woording van een klinisch onderzoek. Leuven: Centrum voor Biomedische Ethiek en Recht, faculteit Geneeskunde.

Schwandt, T.A. (2001) Responsiveness and every day life. In: J.C. Greene \& T.A. Abma. New directions for evaluation, (92), 73-88.

Sevenhuijsen, S.L. (2000) De plaats van zorg. Over de relevantie van zorgethiek voor sociaal beleid. (oratie), Utrecht.

Smits, M.J. (1997) Ethiek van de verpleegkundige praktijk, Zorgethiek of regelethiek? Verpleegkunde, 12, (I), 27-35

Spiers, J.(1997) Who Ouns Our Bodies? Making moral choices in health care. Oxford: Radcliffe Medical Press.

Stichting Leger des Heils Welzijns- en Gezondheidszorg (I999) Hospice Rozenheuvel, gasthuis voor terminale patiënten, Rozendaal.

The, A.M. (1997a) Palliatieve behandeling en communicatie, een onderzoek naar het optimisme op herstel van longpatiēnten. Houten/Diegem: Bohn Stafleu Van Loghum.

The, A.M.(I997b) 'Vanavond om 8 uur...' Houten/Diegem: Bohn Stafleu van Loghum.

Thiel, G. van \& M. van den Hoven (1999) Als mensen aandacht te kort komen, smaakt het kopje thee ook niet. Utrecht: CBG.

Tronto, J.C.(1993) Moral Boundaries, a Political Argument for an Ethic of Care. New York: Routledge.

Verhagen, E.H., M.R. Eliel, A. de Graeff \& S.C.C.M. Teunissen (1999) Sedatie in de laatste levensfase. Nederlands Tijdschrift voor Geneeskunde, 143, (52). 2601-2603.

Verkerk, M.A. (I999) 'A Care Perspective on Coercion and Autonomy', Bioethics, 13 (3-4). 358-368.

Verkerk, M.A. (200o) De organisatie als praktijk van verantwoordelijkheid. In: Graste en Bauduin (red.). Waardenvol werk. Ethiek in de geestelijke gezondheidszorg. Assen: Van Gorcum, 112-125.

Verweij, M.F., F.W.A. Brom, A.K. Huibers (I999) Ethiek in Commissies, Nederlandse Vereniging voor Bio-ethiek.

Wal, G. van der \& P.J. van der Maas (1996) Euthanasie en andere medische beslissingen rond het levenseinde. Den Haag: Sdu Uitgevers.

Walker, M.U. (1998) Moral Understandings, a Feminist Study in Ethics. New York/London: Routledge.

Wester, F. (1995) Strategieën voor kwalitatief onderzoek. Bussum: Coutinho.

Widdershoven, G.A.M. (1987) Handelen en rationaliteit, een systematisch overzicht van het denken van Wittgenstein, Merleau Ponty, Gadamer en Habermas. Amsterdam/Meppel: Boom. 
Widdershoven, G.A.M. (1995) Principe of Praktijk, een hermeneutische visie op gezondheid en zorg. (rede uitgesproken bij de aanvaarding van het ambt van bijzonder hoogleraar Hermeneutiek en Gezondheid aan de faculteit der gezondheidswetenschappen) Maastricht: Rijksuniversiteit Limburg.

Widdershoven, G.A.M. (1997a) Kwaliteitszorg: welke stem krijgt de patiënt? $2 \mathrm{Q}, 8 \mathrm{I}-86$.

Widdershoven, G.A.M. (1997b) Eerder naar huis? Een intersubjectieve benadering van beslissingen rond transmurale zorg. Medisch Contact, (52), 316-318.

Widdershoven, G.A.M. (1998) Autonomie in de hulpverlening. Tijdschrift voor de sociale sector, $(\mathrm{I} / 2), 20-25$.

Widdershoven, G.A.M. (2003a) Luis in de pels. Tijdschrift voor Geneeskunde en Ethiek, 10, (3), 77-82.

Widdershoven, G.A.M. (2000b) Ethiek in de kliniek. Amsterdam/Meppel: Boom.

Willigenburg, T. van, A. van den Beld, F.R. Heeger \& M.F. Verweij (1998) Ethiek in praktijk. Assen: Van Gorcum.

Zylicz, Z. \& M.J.P.A. Janssens (1998) Options in Palliative Care, dealing with those who want to die. Baillère's Clinical Anaesthesiology (12), 121-131 



\section{Persoonsnamenregister}

Abma (1996), 23, I18-I19, I21, 124, I29, I30-131, 133, 163, I86, 190, 204

Abma (2000), 126,

Abma (200I), 128

Abma \& Stake, I9, I20-121

Abma \& Widdershoven, 231

Asperen, van, 34, 46, 66, 79, 96-97,

III

Beauchamp \& Childress, 59, 60

Begeman, 35, 44, 45, 46, 73-75, 77 , $78,97, \mathrm{III}, \mathrm{I} 43,224$

Belderok, 92

Boot \& Knapen, 42, 43, 46

Borst-Eilers, 19

Broeckaert, 215

Bruntink, 100

Dartel, van, 99, 104

Dekkers, 2 I4

Dondeyne, roo

Doyle, 48, 93

Dupuis, 46

Francke, 41, 42

Gadamer, 35, 74, 75, 77, 89, 97, r3I, I6o
Giddens, 27, 28, 31-40, 46, 52, 57, 75, $76,87,89,92,93,96$, 109, 150, I84, 201, 224

Gilligan, 67

Guba \& Lincoln, 23, II8-121, 124, 131, 133, 134, 186, 204

Habermas, 23, 27, 29, 31, 35, 39, 52, $78,87,89,96, \mathrm{m1}, 224$

Hammersly \& Atkinson, I86

Hattinga Verschure, 32, 43

Have, ten, 59, 60

Integraal Zorg Overleg, 172

Janssens (1999), 48, 57

Janssens (2001), 93, 100, 182, 206 , 214

Janssens (2002) 215

Jonker, 208

Keirse, 87, r6o

Korthals, $5^{8}$

Kübler-Ross, 47

Kunneman (1986), 29-31

Kunneman (1996), 19, 90, 109, 143

Kunneman (1998), 23, 88, 97-98, I06, III, I49, 157, 160, 162, 164, I91, 199, 203, 220 
Kunneman (1999), 9I, 104, 156, 201, $203,218,224,230$

Maas, van der, \& Van Delden \& Pijnenborg, 50

Manschot, 70-71, 79, 80, 227

Manschot \& Verkerk, $128,{ }_{5} 8$

McClelland \& Sands, $175-176,183,187$

Moen \& Abma, I26

Moody, 85

Nijs, de, 87

NPTN, 57, IO9, III

Nuij \& Hoogerwerf, 205, 213-214

Núnez, 215

Nussbaum, 66, 103, 150, 174, 176, 191$192,217,226$

Orshoven, van \& Van Menten, 49, 86, 87,206

252

Osselen, van, (1989) 67,77

Osselen, van (1997) 51, 59

Osselen, van \& Vigelius, 25

Pijnenburg, Mulder \& Schellekens, III

Poppema \& Ziedses, 125

Prins, 206

Projectgroep Integratie Hospicezorg (200I), 123

RIVM, I7

Saunders (I990), 51

Saunders (1993), 47

Scholberg, 50

Schotmans, 100, 208

Schwandt, 119, 121, 133

Sevenhuijsen, 204

Smits, 67

Spiers, 87
Stake, 119-121

Stichting Leger des Heils, 122

The (1997a), 194, 219

The (1997b), 88, 148, 191,

Thiel, van, \& Van der Hoven, 58

Tronto, 23, 67, 68, 71, 72, 79-81, 103. $105,107,108,110,111,113,176,203$, 204, 207, 209

Verkerk (2000), 79, 89, 91, 100, 103105, 156, 171, 191, 192, 203, 204, 218,230

Verweij, 106

Ministerie van VWS, 50

Wal, van der \& Van der Maas, 50

Walker, 66, 72, 76, 79, 85, ro8, r7r

Wester, 120, 133

Widdershoven (1987), 39-40

Widdershoven (1995), 66, 92, 93, 96

Widdershoven (1997b), IOI

Widdershoven (2000/2000b), 59, 60. $62,64,65,69,71,72,74,75,78,80$, $90,97,127,128,131,191,227$

Widdershoven (2002), 231

Willigenburg, van, 59, 60, 61, 63, 64, 65

Ziedses, 125

Zylicz, 87 


\section{Trefwoordenregister}

Adequaatheid,

referentiële -, 134

Afhankelijkheid, 66

Autonomie, 59, 63, 70, 80

Betrokkenheid,

langdurige $\cdot, 133$

Care, $43-44$

-giving, $67-68$

-receiving, $67-68$

Caring about, 67

Communicatie, $86-87$

een ideale - gemeenschap, 39

Conflictvermijding, 126

Controlemechanisme, 29

Cure, 43-44

Dehydratie, 214-215

Dynamiek van de moderne tijd, 32, 36

Effect,

dubbel -, 214

Emancipatie, 37

Ervaring, 66

Ethiek,

$$
\begin{aligned}
& \text { regel-, 58,65 } \\
& \text { zorg-, } 58,67,70,75
\end{aligned}
$$

Ethisch beraad, 203

Euthanasie, 205
Gezondheidszorg,

het systeem van de $\cdot$, 42-43

Hermeneutiek, 73, 75, 89.90

Hermeneutisch proces, 133

Horizonversmelting, 74, 76

Identiteit,

individuele,- 38

Insiderperspectief, $\mathrm{n} 8$

Kolonisering, 3I

Kwetsbaarheid, 66, 69-70, 96

Learning,

didactical -, I2I

discovery $\cdot, 121$

Leefwereld, 29

Life-politics, 28, 36-40, 93

Mechanismen van de huidige tijd, 3I

Member check, 133

Moderne tijd, de -, 29

Narratieve benadering, 127

Onderzoek, leefwereld -, II8

responsief -, II7, II9 
Palliatieve, week van de - zorg, III - zorg, 40, 43, 48-51 - zorgbeweging, 40 -zorgverlening, 45, 47

Paradox, 3I

Peerdebriefing, 134

Principes, 60

Professionaliteit, normatieve -, 88, I49

Rationaliseringsprocessen, 29

Reflectie, 150

ethische -, ro5

morele -, 106

Reproductie,

materiële -, 30

symbolische - 30

Responsive, 186

Responsiveness, 68, II9

254

Schemergebied, 205

Schijnconsensus, 78

Sedatie, 100, 205, 210

Stappenplan, 60-6I

Systeemwereld, 30

Systemen,

expert-, 34

sub-, 29-30, 39

Taal,

gaten in de,- 97

Taalgebruik,

symbolisch - 86.87

Taking care of, $67-68$

Tegenbeweging, 31

Traditie, 29, 35. 97-98

Triangulatie, 133
Verantwoordelijkheid, $105,176,204$

Verkeerde bed, het - , 76, 189

Vervreemding, 92

Vragen,

trage -, 91, 104, 156-I57

Werkingsgeschiedenis, 74

Zelfbeschikking, 59 


\section{Curriculum vitae}

Adriana (Jeanette) van Osselen - Riem, in 1944 te Rotterdam geboren, slaagde in 1966 voor haar opleiding tot verpleegkundige in het Dijkzigt Ziekenhuis in Rotterdam (Verpleegkundige A + kraamaantekening). Zij onderbrak in 1969 haar werk als operatieverpleegkundige na de geboorte van haar eerste kind. De zorg voor haar gezin combineerde zij met vrijwilligerswerk voor de jeugd. Zij was mede oprichter van de Stichting Vrij Spel (vakantie spelweken en clubwerk). In 1979 nam zij de draad als operatieverpleegkundige weer op in het St. Radboud Ziekenhuis te Nijmegen. Daar ontstond de behoefte om het perspectief te verleggen en begon zij aan de Hoge School voor Verpleegkundigen te Nijmegen aan de opleiding tot docent verpleegkunde. Zij zette haar studie voort met de opleiding (Sociale) Pedagogiek M.O.-A en M.O.-B (voltooid in 1988). Aansluitend behaalde zij aan de Katholieke Universiteit Nijmegen het doctoraalexamen in de Pedagogische Wetenschappen, differentiatie Wijsgerige Pedagogiek. (Scriptie 1989: Hoe hermeneutisch is het genetisch structuralisme?). Tijdens de studie werkte zij als freelancer aan het opzetten en organiseren van bijscholingscursussen in de gezondheidszorg (Methodische praktijkbegeleiding, 1989). Voor het Rode Kruis werkte zij mee aan het schrijven van docentenhandleidingen en het ontwikkelen van toetsen bij leermodules (1987-1988). Daarnaast werkte zij mee aan de opzet en uitvoering van onderzoek ter gelegenheid van het 70-jarig jubileum van de VVAO (Vereniging van Vrouwen met Academische Opleiding). Een onderzoek naar modellen om werk- en zorgtaken te combineren (Deeltijd: Verleden Tijd of Toekomst?, (VVAO, 1994).

Begin jaren negentig raakte zij betrokken bij de opkomst van de palliatieve zorg in Nederland. Zo organiseerde zij studiebijeenkomsten in Hospice Rozenheuvel voor en met zorgverleners. Zij was werkzaam bij de Stichting de Schutshaven in Rotterdam, om scholingsbijeenkomsten te organiseren en werkte daarnaast als vrijwilliger voor de Stichting Elckerlyck, om bekendheid te geven aan de palliatieve zorg en initiatieven op dat gebied te ondersteunen. In I995 nam zij het initiatief om een leergang palliatieve zorg te ontwikkelen 
voor zorgverleners en vrijwilligers. Daarvan was zij co-auteur en voerde zij de eindredactie (Hulpverlenen doe je samen, leergang palliatieve zorg, 1997).

In 1994 publiceerde zij haar eerste dichtbundel: Woordenwolken in mijn hoofd, in 1999 gevolgd door Verbeelding, werk in steen en op papier, uitgegeven samen met beeldend kunstenaar Anneke Vigelius.

Vanaf 1996 woonde zij met haar man, die daar voor zijn werk was gedetacheerd, tweeënhalf jaar in Oostenrijk (Klosterneuburg). Daar werkte zij drie dagen per week als vrijwilliger in een hospice in Wenen (St. Raphaëls Hospiz). Hier deed zij praktijkervaring op en ontstond de aanzet voor dit onderzoek. $\mathrm{Na}$ terugkeer in Nederland was zij betrokken bij de oprichting van hospice Heuvelrug te Zeist, waar zij ook nu nog een bestuursfunctie vervult. Tevens werkte zij als eindredacteur en co-auteur aan het boek Theorie en Praktijk van de Palliatieve Zorgverlening, Lemma, 2000. 

